\title{
eopal \\ WHOI-97-03
}

\section{Woods Hole Oceanographic Institution}

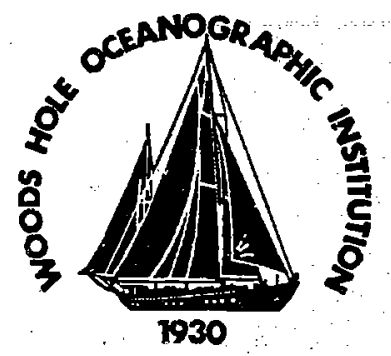

\section{Expendable Oceanographic Mooring (XMOOR)}

by

Daniel E. Frye, Donald Peters, and Richard Arthur

April 1997

\section{Technical Report}

Funding was provided by the Office of Naval Research through Contract Nos: NoO0-14-92-C-6028 and N000-14-95-1-0774.

Approved for public release; distribution unlimited. 
WHOI-97-03

Expendable Oceanographic Mooring (XMOOR)

by

Daniel E. Frye, Donald Peters, and Richard Arthur

Woods Hole Oceanographic Institution

Woods Hole, Massachusetts 02543

April 1997

Technical Report

Funding was provided by the Office of Naval Research through Contract Nos. N000-14-92-C-6028 and N000-14-95-1-0774.

Reproduction in whole or in part is permitted for any purpose of the United States Government. This report should be cited as Woods Hole Oceanog. Inst. Tech. Rept., WHOI-97-03.

Approved for public release; distribution unlimited.

Approved for Distribution:
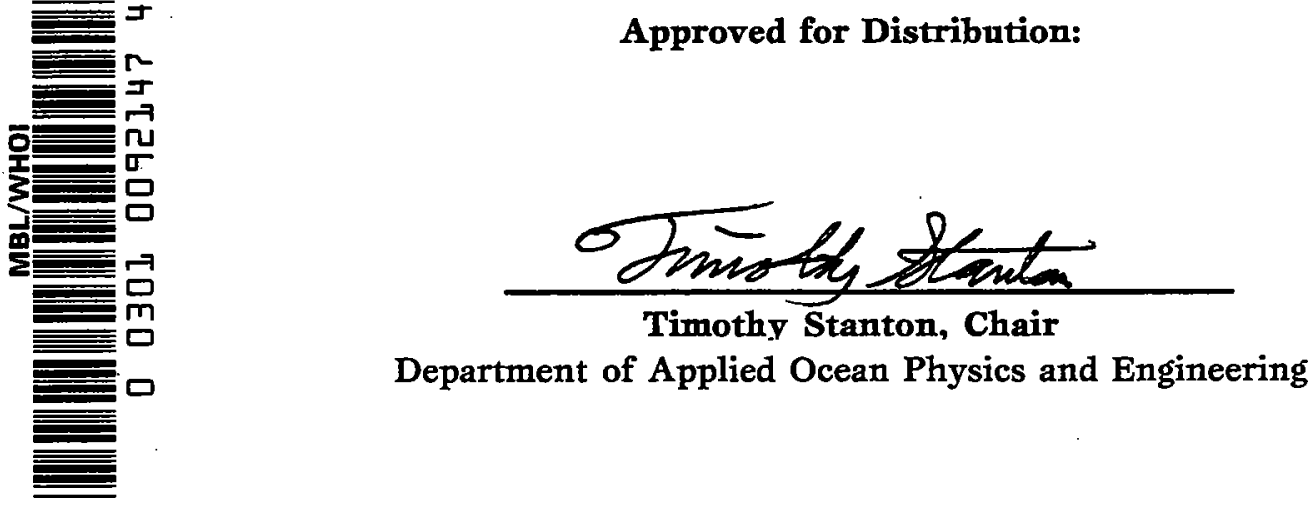
.

. 


\title{
EXPENDABLE OCEANOGRAPHIC MOORING (XMOOR) Daniel E. Frye, Donald Peters, and Richard Arthur
}

\author{
TABLE OF CONTENTS
}

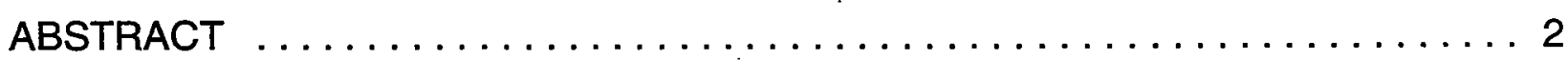

ACKNOWLEDGMENTS $\ldots \ldots \ldots \ldots \ldots \ldots \ldots \ldots \ldots \ldots \ldots \ldots \ldots \ldots$

1. INTRODUCTION ................................... 4

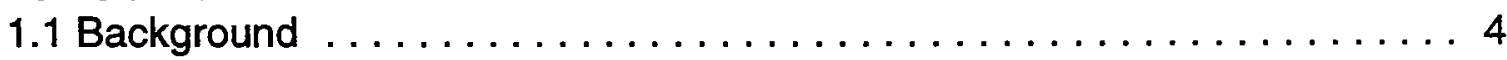

1.2 Project Organization $\ldots \ldots \ldots \ldots \ldots \ldots \ldots \ldots \ldots \ldots \ldots \ldots \ldots$

1.3 Design Objectives $\ldots \ldots \ldots \ldots \ldots \ldots \ldots \ldots \ldots \ldots \ldots \ldots \ldots 4$

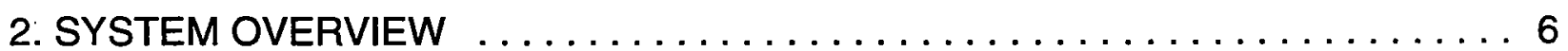

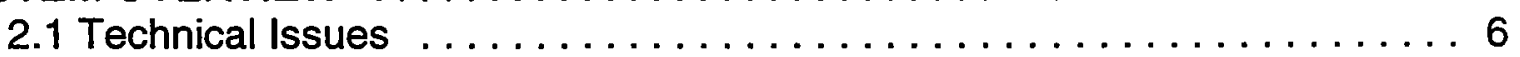

2.2 General Description $\ldots \ldots \ldots \ldots \ldots \ldots \ldots \ldots \ldots \ldots \ldots \ldots \ldots$

2.3 System Operation $\ldots \ldots \ldots \ldots \ldots \ldots \ldots \ldots \ldots \ldots \ldots \ldots . . \ldots$

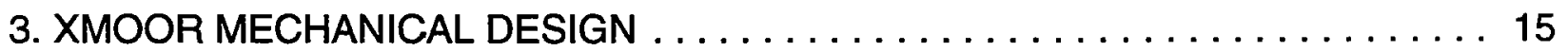

3.1 Surface Buoy and Instrument Housing $\ldots \ldots \ldots \ldots \ldots \ldots \ldots \ldots \ldots$

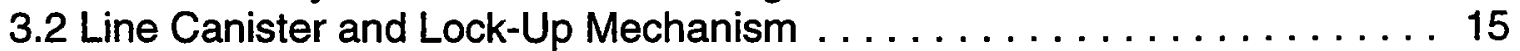

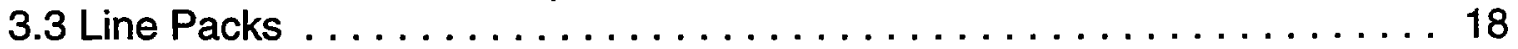

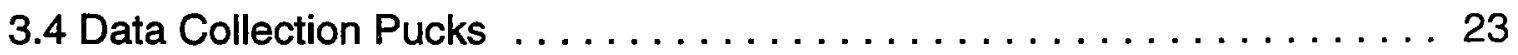

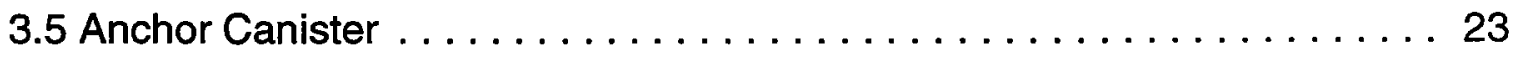

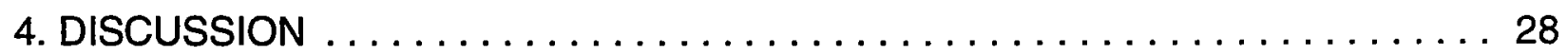

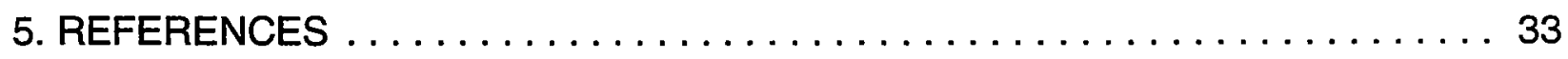

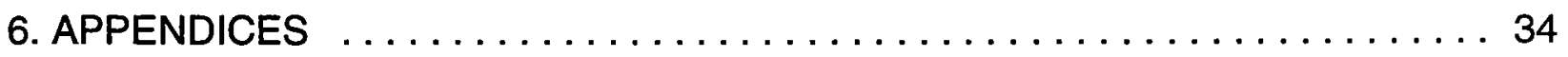

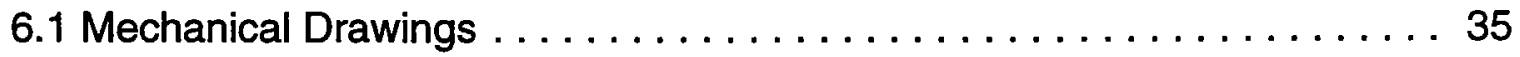

6.2 Selected Model Runs . . . . . . . . . . . . . . . . . . . . 108

6.3 Test Reports . . . . . . . . . . . . . . . . . . . . . 112 


\title{
EXPENDABLE OCEANOGRAPHIC MOORING (XMOOR)
}

\author{
Daniel E. Frye, Donald Peters, and Richard Arthur
}

\section{ABSTRACT}

An expendable, self-deploying mooring (XMOOR) for shallow water applications has been developed to address Navy requirements for environmental monitoring. The project has been conducted jointly between the Woods Hole Oceanographic Institution and the Naval Research Laboratory at Stennis, MS. WHOI has taken the lead on the mechanical design of the system while NRL has developed the electronics.

Eight prototype XMOOR systems have been built. They are designed for water depths between 10 and $100 \mathrm{~m}$, for deployments of up to 3-months' duration, and for automatic deployment. Their sensor suite includes barometric pressure, air temperature, water temperature at up to 25 levels, and conductivity and pressure at up to 3 levels. Data telemetry is accomplished via the Argos DCS and by line-of-sight VHF radio. The radio link provides two-way communications to allow for remote configuration of the data collection program.

This report describes the XMOOR mechanical system. The data collection and telemetry systems are described separately in [1] and [2]. 


\section{ACKNOWLEDGMENTS}

The Expendable Oceanographic Mooring project has been funded by the Office of Naval Technology under Grant No. N000-14-92-C-6028 as part of the Tactical Oceanography Program and by the Office of Naval Research under Grant No. N00014-95-1-0774. Dr. Lou Goodman from ONR's Code 322PO, was the Program Manager for the ONR-funded work. Individuals at NRL who contributed to the project include Janice Boyd (Co-PI), Richard Burnes (Neptune Sciences, Inc.), Bruce Bricker (Planning Systems, Inc.), and Ray Burge. 


\section{INTRODUCTION}

\subsection{Background}

The Expendable Oceanographic Mooring project was a multi-year technology development conducted jointly between the Woods Hole Oceanographic Institution and the Naval Research Laboratory at Stennis, MS. It was begun in FY93 with funding from the Office of Naval Technology as part of the Tactical Oceanography Program and was completed under ONR sponsorship early in 1996. The first year's program was devoted to the development of an expendable mooring for depths up to $300 \mathrm{~m}$ with the potential to handle $3000 \mathrm{~m}$ depths. Two prototype systems were built and successfully tested in August 1993 offshore Provincetown, MA. Based on these results, on feedback from potential Navy users of the device and on the new emphasis being placed on shallow water applications by the Navy, a modified specification was developed during the Fall of 1993 and Winter of 1994. This new specification was then used as the basis for the development of a smaller, lighter, shallow-water oriented mooring which was designed and built in FY 94 and FY95. Eight prototypes were fabricated at WHOI and seven were transferred to NRL for integration with electronics and sensors and for further testing. To date, NRL has deployed fully integrated XMOORs on two Navy research cruises [1].

\subsection{Project Organization}

The XMOOR design and development effort was conducted jointly between WHOI and NRL. WHOI was responsible for the mechanical design, the overall mooring configuration, the automatic deployment system, and the in-line data collection pucks. NRL was the lead on the data acquisition and telemetry electronics, software development for data collection, processing and telemetry, and sensor integration. The inductive telemetry link used to transfer data from the data collection pucks to the surface controller was originally developed at WHOI on the first generation XMOOR, but was implemented on the second generation XMOOR prototypes by NRL [2] , [3], and [4].

Both NRL and WHOI were involved in at-sea tests. WHOI performed various mechanical and mooring tests in local waters near Woods Hole, while NRL performed several offshore deployments of fully integrated XMOORs on Navy cruises. This report describes the WHOI contributions to the XMOOR project with a brief description of the system electronics and sensors.

\subsection{Design Objectives}

XMOOR specifications developed for the shallow-water environment were based on the following requirements. The system should be as small and light as possible, be completely self-deploying in depths up to $100 \mathrm{~m}$, be capable of operating for three months in most nearshore environments, and provide real-time data on important water 
column properties. These general design objectives were developed into an initial specification for the first eight prototypes which is shown in Table 1-1. The long range goal of further miniaturizing the system so that it would be compatible with sonobuoy delivery systems, i.e., air-deployable $12 \mathrm{~cm} \mathrm{(4} \mathrm{7/8} \mathrm{inch)} \mathrm{diameter} \mathrm{by} 91 \mathrm{~cm}$ ( 36 inches) long cylinders was delayed until the XMOOR prototypes proved successful. Since several of the design concepts were quite new and therefore high risk, it was decided that it would not be cost effective to expend substantial resources on miniaturization of high risk designs until they were proven to be reliable in a range of ocean environments.

TABLE 1-1: XMOOR Prototype Specifications

SIZE:

WEIGHT:

OPERATIONAL RANGES:

SENSOR CONFIGURATION:

TELEMETRY CAPABILITIES:

DEPLOYMENT:
Length $1.67 \mathrm{~m}(65.6 ")$

Diameter $17.5 \mathrm{~cm}(67 / 8 ")$

$45.5 \mathrm{~kg}$ (100 lbs)

Water depth: 10-100 meters

Current: $0-150 \mathrm{~cm} / \mathrm{sec}(0-3$ knots $)$

Duration: 0-3 months

Atmospheric: air temperature barometric pressure

Oceanographic: temperature (up to 25 depths) conductivity (up to 3 depths) pressure (up to 2 depths)

Long range: Argos (256 bits per transmission) Short range: VHF (9600 bits/sec) On the mooring: Inductive (1200 bits/sec)

Deployable by a single untrained person Data collection rates configurable prior to deployment or remotely by RF link 


\section{SYSTEM OVERVIEW}

\subsection{Technical Issues}

To meet the design objectives, the development of a number of new approaches to shallow-water mooring systems was required. The underlying issues can be divided into four areas, but obviously they must all fit together as an integrated design. This section provides the rationale for the design approach taken in the XMOOR prototype.

Mooring Design: The mooring design was a key element in the overall system design. XMOOR is necessarily a surface mooring because continuous access to the RF telemetry channel is a requirement, as are meteorological sensors. The surface buoy has to be inflatable to meet the mooring payload requirement and the packaging dimensions. Successful surface moorings with small anchors (i.e., using embedment techniques rather than deadweight to moor the system) require reasonable scope and a low angle of attack at the anchor. To meet these requirements along with the packaging and weight limitations, a folding, omnidirectional, lightweight anchor was developed and packaged with $15 \mathrm{~m}$ of chain.

The chain provides scope and compliance to absorb wave energy and minimizes the angle of attack at the anchor. Since surface moorings have high loads on their mooring lines due to wave forcing, the mooring line needs high strength, high resistance to bending loads, and general robustness. These requirements suggested wire rope or high-strength synthetic lines for the mooring strength member. The decision to use the high strength synthetic Vectran rather than wire rope was predicated on the self-deployment and packaging requirement. Wire rope (or E/M cable) could not be packaged in the small diameter XMOOR container due to its inherent stiffness. Potential high-strength synthetics including Kevlar, Spectra, and Vectran were evaluated as mooring line candidates. Vectran was chosen for its high strength (equivalent to Kevlar or Spectra), high resistance to bending degradation (a major problem with Kevlar), and low creep (Spectra's major shortcoming).

Self-deployment also required a lock-up mechanism on line payout to provide automatic scope adjustment for varying water depths. This is particularly important in shallow water situations, where too much line deployed could result in tangling, snagging on the bottom, or vulnerability to vessel traffic (if excess line was floating at the surface).

Two basic types of lock-up mechanisms were considered: continuous and discrete. The continuous technique arrests the mooring line at any point along its length. A discrete mechanism uses preselected points on the line to hold the mooring. The discrete lock-up approach was chosen for XMOOR to minimize the potential for failure at the lock-up point. The lock-up points were designed specifically to minimize bending and chafing which could lead to a failure at the stress concentration point. 
The discrete lock-up points that were developed for XMOOR use a hollow braid spectra lanyard Chinese-fingered over the mooring line to transfer the mooring load from the mooring line to a short piece of stainless steel chain. The mooring line is relieved of the mooring load without being bent where it is in tension. The free end of the spectra hollow braid, which is very robust in bending and chafing situations, is terminated in an eye splice around an endless stainless steel thimble. This thimble is shackled to a short piece of stainless steel chain that terminates at a lock-up fitting.

The spectra lanyard termination was incorporated not only-at the discrete lock-up points, but also at the termination of the mooring line to the surface buoy. In this location the lanyard thimble was captured in a welded bail fixed to the bottom of the instrument housing located just beneath the buoy. The free end of the mooring line was then whipped alongside this top termination lanyard and sleeved in polyester material up to the thimble at the bottom of the housing. It was then looped and electrically spliced to a pigtail ending in a connector plugged into the instrument housing endcap.

In addition, a pair of these lanyards were employed at the mid-water data collection puck location, where they transferred mooring loads from the mooring line to the top of the puck housing, and from the bottom of the puck housing back to the mooring line. This eliminated a stress concentration at the point where the mooring line passes through the puck.

The lock-up latching mechanism closes when the lower section of XMOOR (the anchor canister/line canister combination) hits the bottom. Any lock-up points passed while the canisters are still falling through the water are simply pulled out past the latch. When the canisters reach the bottom, line continues to be pulled out by the action of wind and current on the mooring, until the next lock-up point is captured in the closed latch. The lock-up system therefore always results in additional line being payed out after the system reaches the bottom, providing some, but not excessive, scope. The locations of the four lock-up points on the prototype mooring lines were chosen to give acceptable ranges of scope for the specified range of water depths.

Three-Month Life: A major feature in the XMOOR design, differentiating it from expendable sensors like sonobuoys and XBTs, is the requirement for three-month life. This lifetime is not far removed from the oceanographic standard of six to twelve months for relatively massive, manually deployed systems weighing thousands of pounds [5]. To meet this requirement the system components have been made as robust as possible within the available size and weight constraints. Particular problems that had to be solved to meet the three-month life requirement were gas leakage in the inflatable buoy and failure of the mooring line where it connects to the surface buoy, the data collection pucks, and the lock-up points.

The issue of long-term durability was a particular design driver for the mooring line and the various sensor attachment points. A design using a multiconductor 
Vectran cable with breakouts for each thermistor, conductivity and pressure sensor would have been a simpler conceptual approach than the XMOOR design, but this approach would require 20 or more conductors to be subjected to the bending and tension loads of the mooring line, which would significantly increase the potential failure rate. All of the electrical breakouts would also have increased the chance for failures due to water leaks. The XMOOR design uses a single, highly helixed conductor in conjunction with several inductive modems/data collection pucks so that only one robust conductor is subjected to the full loading of the mooring. Very lightweight thermistor chains are then married to the mooring line in a way that puts no strain on the thermistor chain wiring and a single watertight connection is made to the data collection puck. The mooring line is continuous through the pucks, so no electromechanical terminations are required. A third option was also evaluated; two- or three-conductor Vectran cable with hardwired data telemetry from each puck could also have been implemented in XMOOR with some increase in the size of the Vectran. At this point in time, there is no clear answer to which of these two approaches (the single conductor or the 2 or 3 conductor approach) is best in terms of robustness, cost, and ease of use. The inductive link has led to some problems during testing. Whether these problems are significant in the long run is unclear.

Packaging: XMOOR packaging and weight constraints have also played a significant role in driving the prototype design. The surface buoy material was chosen so that it could be packed in a small volume. The requirement to use $\mathrm{N}_{2}$ gas to inflate the buoy made the packaging problem difficult since eight bottles are required for inflation - each with its own seawater-activated inflation device. Maximum mooring line size was strongly influenced by the line canister dimension and maximum anchor size was also determined by the anchor canister dimensions. Anchor type (embedment) was forced by the weight constraint.

Finally, the data collection puck dimensions were driven by the canister diameter and the limited length of the line canister that contains both the line and the data collection pucks prior to deployment. Since each puck is a stand-alone CTD with inductive modem, thermistor chain electronics, and three-month battery pack, the requirement to produce a puck $15 \mathrm{~cm}$ ( 6 inches) in diameter by $7.6 \mathrm{~cm}$ ( 3 inches) high was a significant challenge.

Cost: An expendable mooring needs to be inexpensive. The XMOOR mechanical system could be made inexpensive to manufacture in quantity with some further investment in engineering and tooling. As with miniaturization, it was not cost effective to perform a serious engineering effort to minimize production costs until the system design was fully evaluated. The prototype XMOOR system has a parts cost of about $\$ 15,000$ which is dominated by the sensor and electronics components ( $2 / 3$ of the total). The present mechanical components, which include all of the mooring components, anchor, buoy, self-deployment system, etc., cost about $\$ 4,500$. About two days of technician time are needed to assemble the system (in a lot of eight units). 


\subsection{General Description}

The XMOOR prototype is shown in Figure 2-1. Figure 2-2 is a photograph of an XMOOR ready for deployment. Figure 2-3 shows the system after deployment. An inflatable surface buoy provides a platform for VHF and Argos transmitter antennas and meteorological sensors and supports the mooring over a wide range of water depths and current loads. An instrument housing positioned immediately below the buoy contains radios, data acquisition electronics, sensors and batteries for up to three months operation (Table 2-1). Beneath the instrument housing, a-line canister holding up to 125 meters of mooring line packaged for automatic deployment and two data collection pucks is positioned. The data collection pucks (one at mid-depth and one at the bottom), contain conductivity, temperature, and depth sensors, inductive modems and toroids, batteries, and electronics for thermistor chains which are married to the mooring line. Finally, an embedment-type anchor with 15 meters of chain provides holding power with scope and compliance to accommodate surface wave action.

\subsection{System Operation}

This section describes the mechanical operation of the XMOOR system during the deployment sequence. Specific details of the mechanical components are covered in Section 3.

Prior to deployment, XMOOR is fully contained in a cylinder $17.5 \mathrm{~cm}(67 / 8$ inches) in diameter by $1.67 \mathrm{~m}$ ( 66 inches) long. XMOOR is deployed by dropping it into the water anchor end first. Its orientation on hitting the water is not particularly important, but the anchor end, which is heavy, should hit the surface first. The undeployed system will sink momentarily but the buoy inflators will completely inflate the buoy within about 15 seconds. There are eight $\mathrm{N}_{2}$ bottles each with an actuator. The actuators are commercially available devices in which spring loaded needles are used to penetrate the gas bottles. They are triggered by the rapid decomposition of a small tablet that reacts with seawater allowing the needles to puncture the tops of the gas bottles.

As XMOOR enters the water the actuator/lock-up drag wing opens. This pulls a retaining pin from a spring-steel mating ring which opens and allows the line canister to separate from the surface pressure housing. The drag wing also engages a retaining pin in a second mating ring holding the breakaway anchor canister together. The line canister and anchor canister then fall to the bottom. Mooring line is spooled in the line canister in two spools separated by the mid-water data collection puck. The line spools are held together with an acrylic mastic. As the canisters fall, line is unspooled and the mid-water puck is pulled out. The drag wing holds the line lock-up mechanism open until the canisters hit the bottom. When the drag wing falls down to a vertical position, it closes the lock-up mechanism and releases the mating ring connecting the line canister and the anchor canister. Current and wind are then relied upon to pull out any 


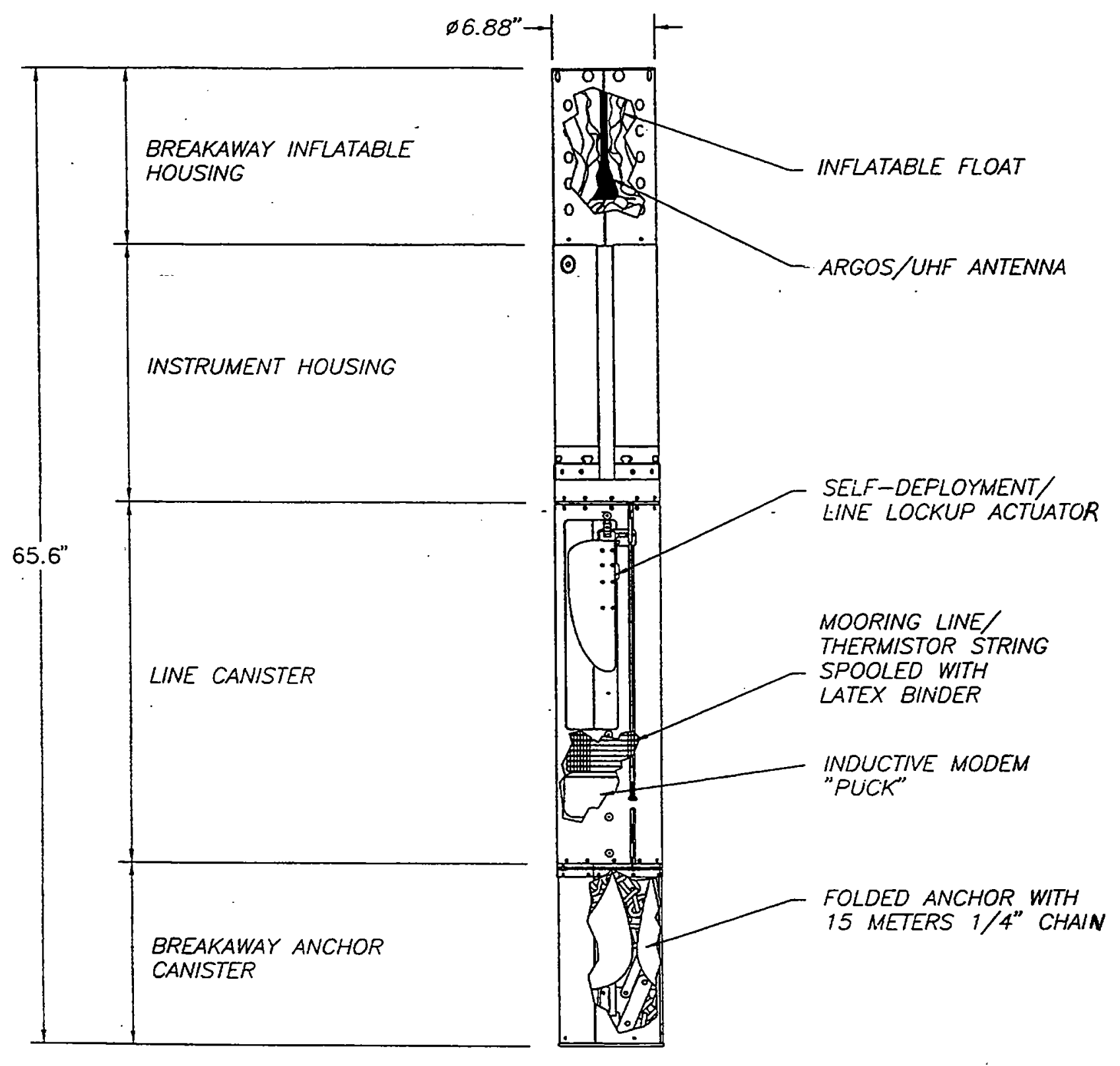

Figure 2-1: XMOOR prototype 


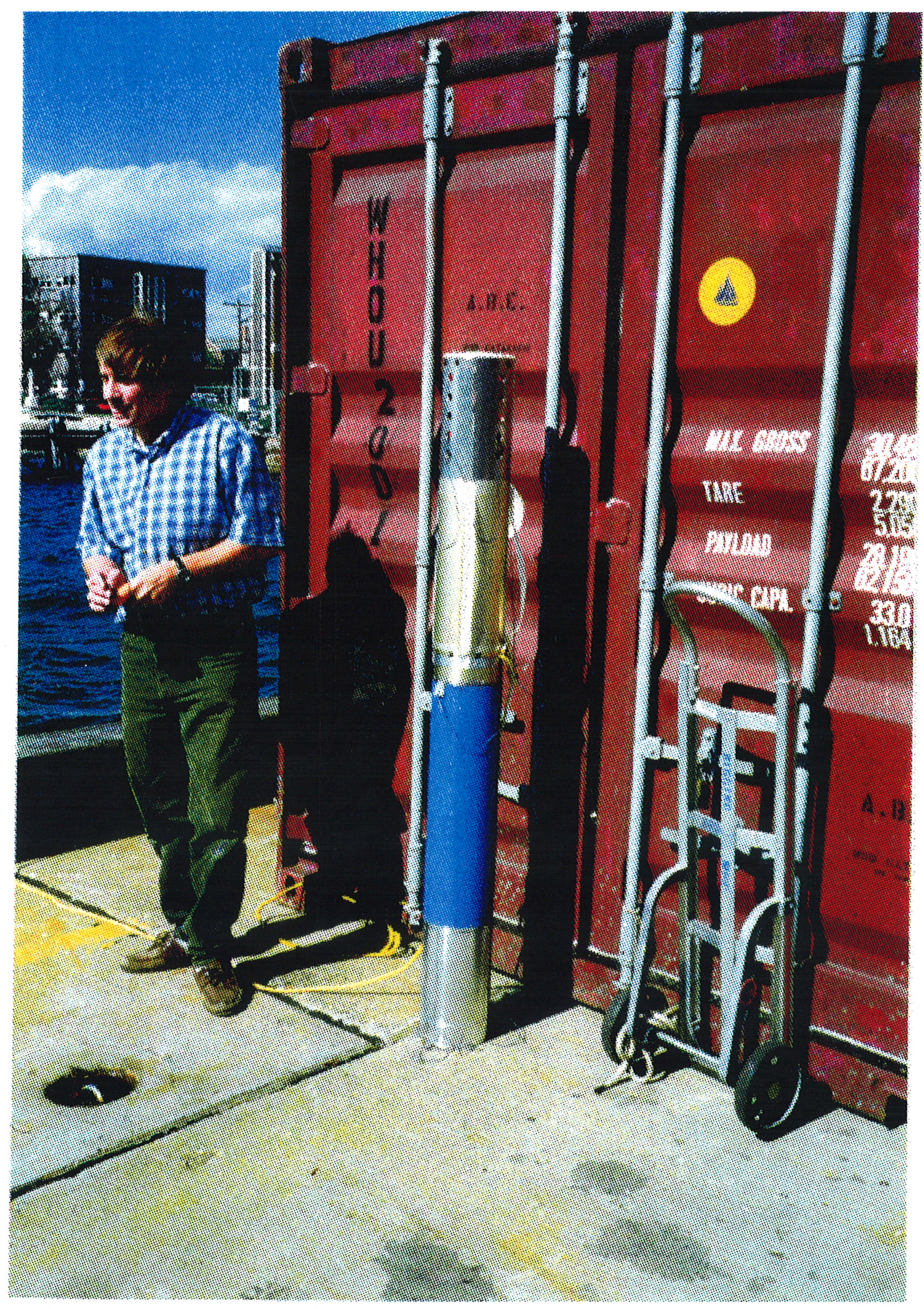

Figure 2-2: XMOOR packaged for deployment 


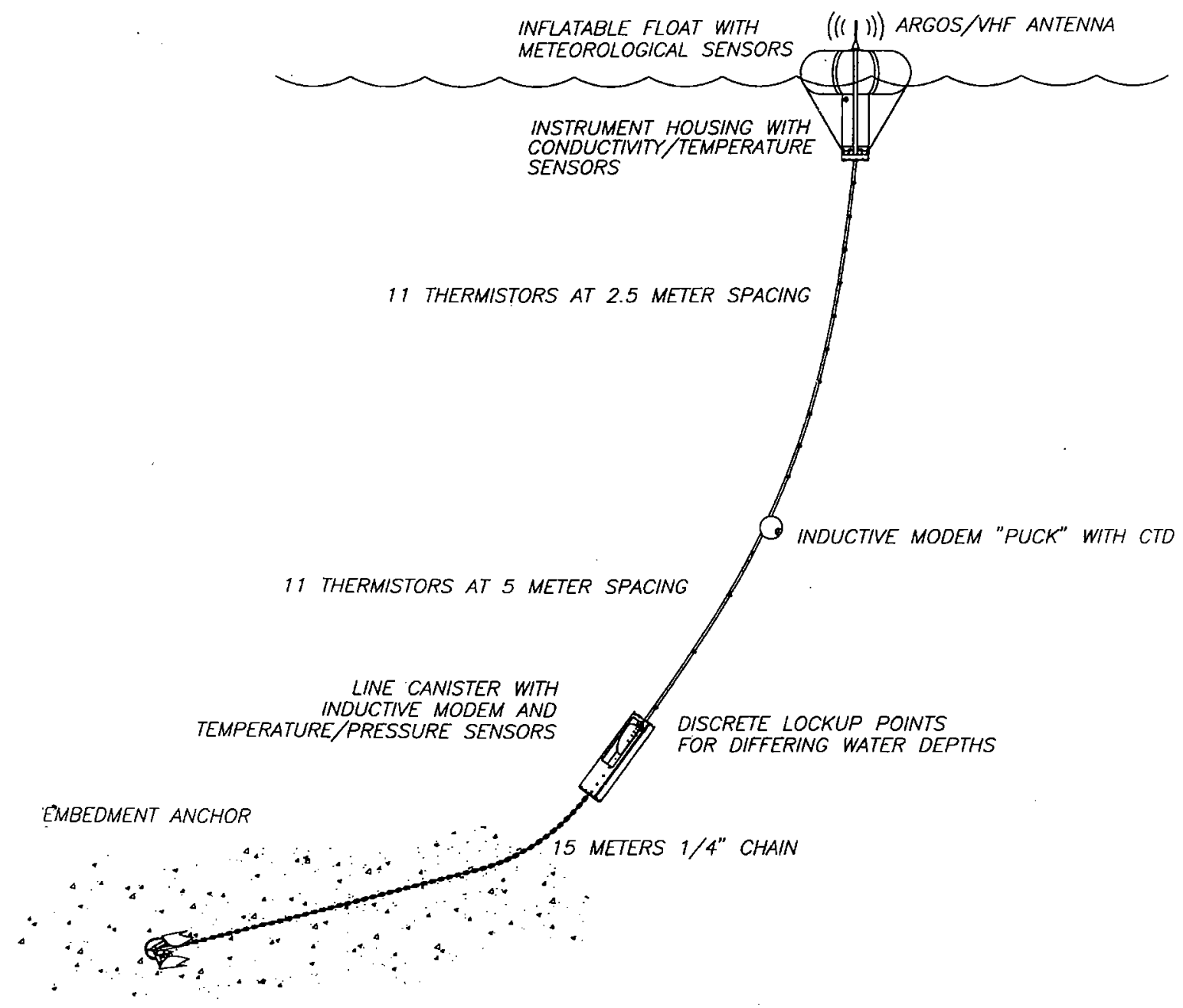

Figure 2-3: XMOOR configuration after deployment 


\section{TABLE 2-1: XMOOR Prototype Payload}

\section{COMPONENTS}

Argos PTT
VHF Radios
Controller
Air Temperature Sensor
Barometric Pressure Sensor
Water Temperature Sensor
Thermistor Chain
Conductivity/Pressure/
Temperature Sensor
Inductive Modem
Surface Buoy
Buoy Inflator
$\mathrm{N}_{2}$ Gas Bottle
Mooring Line

\section{Batteries}

\section{MANUFACTURER MODEL OR DESCRIPTION}

$\begin{array}{ll}\text { Seimac } & \text { SmartCat III } \\ \text { GINA } & \text { Model } 5000 \\ \text { Onset } & \text { Tattletale Model 5 } \\ \text { YSI } & \text { Thermistor 44108 } \\ \text { Motorola } & \text { MPX 4115 } \\ \text { YSI } & \text { Thermistor 44108 } \\ \text { Daycon } & \text { Miniature Tz } \\ & \\ \text { FSI } & \text { Micro CTD } \\ \text { NRL } & \text { 1200 b/s } \\ \text { Patten, Co. } & \text { Modified toroid } \\ \text { Halkey-Roberts } & \text { Auto-inflator } \\ \text { Leland, Ltd } & \text { 2500 psia, 77 cc's } \\ \text { Cortland } & \text { Vectran/Hyline conductor } \\ & \text { (1275 lb RBS) }\end{array}$

Alkaline

21 D-cells

Alkaline
8 AA cells

remaining line (until the next lock-up) and the anchor chain. The anchor embeds as it is dragged by the action of wind and current. In tests in $20 \mathrm{~m}$ of water with $1.5 \mathrm{knot}$ currents, the entire deployment sequence was completed in about 30 seconds. Circular tidal motions may pull the anchor out of the bottom, but its omnidirectional nature allows it to quickly re-embed. In a hard-bottom environment, sharp points on the anchor flukes are designed to snag irregularities in the bottom.

Key points in the operational scenario are:

- $\quad$ The mooring self-adjusts for depths between 10 and $100 \mathrm{~m}$ using discrete lock-up points at $15,30,60$, and 125 meters of line.

Temperature sensors are distributed throughout the water column - at $2 \frac{1}{2}$ meter intervals in the upper layers and at 5 meter intervals in the lower layers. 
- $\quad$ Sensor data collection and data telemetry is controlled by electronics in the housing below the surface buoy. An inductive link is used to access the subsurface data collection pucks using a single conductor in the mooring line with a seawater return. Each puck is addressed with a unique ID and sensor data are immediately transmitted.

Salinity measurements are made using a new highly accurate and very compact CTD packaged specifically. for this application.

- Data are available in real time via a two-way line-of-sight radio link, and a one-way, low baud rate satellite link with global coverage.

Batteries in the surface pressure housing and the subsurface data collection pucks are capable of collecting and transmitting data for up to three months, depending on the duty cycle implemented. 


\section{XMOOR MECHANICAL DESIGN}

\subsection{Surface Buoy and Instrument Housing}

The surface buoy is shown in Figure 3-1a and Figure 3-1b. It has a volume of approximately $88 \mathrm{~L}\left(3 \mathrm{ft}^{3}\right)$ and provides about $890 \mathrm{~N}(200 \mathrm{lbs}$ ) of total buoyancy. It was designed specifically for the XMOOR prototype and is built by Patten Co. of Lakeview, $\mathrm{FL}$, to our specification. Buoy material is nylon coated urethane. Nylon straps hold the pressure housing to the buoy and transfer the mooring load. The buoy is filled with $\mathrm{N}_{2}$ gas supplied by eight high pressure bottles each with $77 \mathrm{cc}$ 's of 2500 psia gas. These bottles are purchased from Leland, Ltd, Bedminster, NJ. Each bottle has an inflator valve with seawater actuator made by Halke-Roberts, St. Petersburg, FL. The bottles are fitted to the buoy in small pockets on the outside surface of the buoy.

The instrument housing is an aluminum cylinder ( $3 \mathrm{~mm}-1 / 8$ inch wall) with an endcap at the bottom. On the top end is a single coaxial connector for the Argos PTT and RF link antenna. A second feedthrough is provided for the barometric and air temperature sensors. On the bottom end cap a connector for the inductively transferred data is located next to a grounding stud used for the seawater return. A padeye for connecting the mooring line is centered on this end cap. Detailed drawings for the surface buoy, instrument housing and all other mechanical components can be found in Appendix 6.1. The instrument housing holds the Argos PTT, VHF transceiver, Tattletale controller, inductive modem, air temperature, barometric pressure and surface water temperature sensors, and battery pack.

\subsection{Line Canister and Lock-Up Mechanism}

The middle section of XMOOR consists of the line canister, which holds the spooled line and data collection pucks prior to deployment. The wall of the line canister houses the drag wing actuator/lock-up mechanism.

The maximum outside diameter of the line canister is limited by the $17.5 \mathrm{~cm}$ (6 7/8 inch) system diameter constraint, while the inside diameter of $16.2 \mathrm{~cm}(63 / 8$ inch) is the minimum diameter found to allow free rotation and pullout of the mid-water puck. The resulting average line canister wall thickness is $6.4 \mathrm{~mm}$ (1/4 inch). Early in the design stage a single mechanism to provide self-deployment actuation and line lockup was envisioned. Since this mechanism would only occupy space on one side of the line canister; it was decided to offset the inside bore of the line canister by $3.2 \mathrm{~mm}(1 / 8$ inch), resulting in a wall thickness of $9.6 \mathrm{~mm}(3 / 8 \mathrm{inch})$ on the actuator side, and $3.2 \mathrm{~mm}$ (1/8 inch) on the opposite side. The resulting increase of volume was enough to allow the actuator/lock-up mechanism to be housed within the wall of the line canister, and not encroach on either the O.D. or I.D. of the canister. 


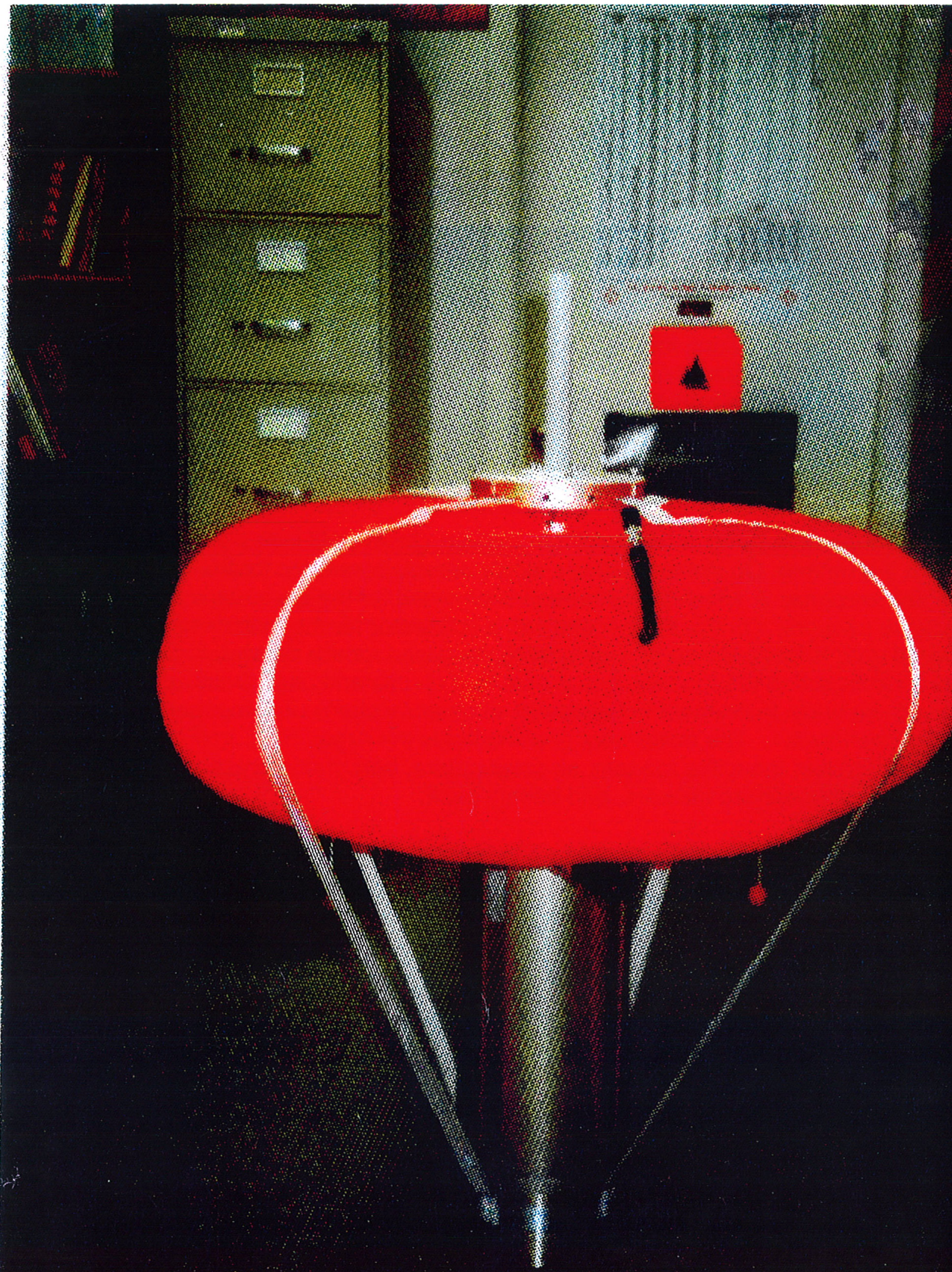

Figure 3-1a: Photograph of XMOOR surface buoy and instrument housing 


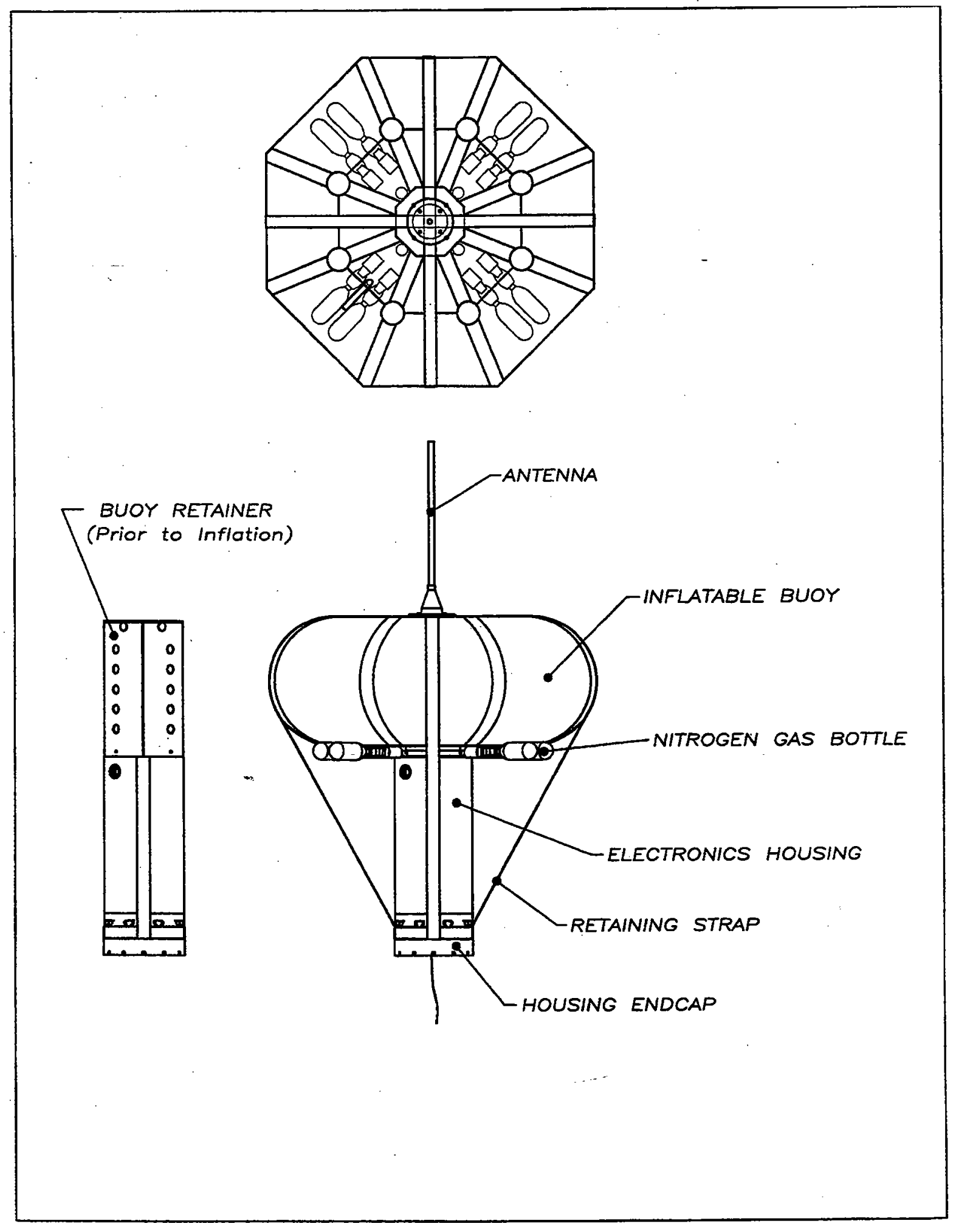

Figure 3-1b: Design of XMOOR surface buoy and instrument housing 
The line canister is a nylon cylinder $17.5 \mathrm{~cm}(67 / 8$ inches) in diameter and $43 \mathrm{~cm}$ (17 inches) long (Figure 3-2a). At the top is a machined ring that connects the line canister and the instrument housing. Along an interior wall is a stainless steel track which acts as both the structural strength member through which the mooring forces pass and as a guide for the individual lock-up slides. Prior to deployment all four lockup slides are placed on and captured by the lock-up guide. As the mooring line is pulled out of the canister during deployment, the slides pull off the top of the guide and out of the canister. When the drag wing, located on the outside of the line canister returns to a vertical position, the top of the guide is closed off and-the next slide to hit the top is captured. This stops further unspooling and transfers the mooring load to the guide. The wing is also locked down once a slide is captured. Any line or sensors left in the canister remain in the canister.

\subsection{Line Packs}

The line packs are constructed with $4.8 \mathrm{~mm}$ ( $3 / 16$ inch) Vectran line with a single copper conductor helixed around a small internal Vectran core. Figure 3-2 shows the line construction and specifications. The line is wound into two line packs in each XMOOR prototype. The top line pack is $30 \mathrm{~m}$ long and attaches to the instrument housing just below the buoy at a padeye. The electrical conductor is terminated to a Mecca connector which plugs into a pin on the bottom end cap of the instrument housing. At the lower end of the upper line pack the line passes through the mid-water data collection puck and through the split toroid in the puck. Mechanical terminations for the surface buoy, lock-up points, and mid-water puck are made by slipping a hollow braid spectra lanyard over the vectran line and then back splicing the spectra lanyard over a stainless steel thimble (see Drawing No. 011-3-0106 in Appendix 6.1) The midwater puck attaches to the line with a spectra lanyard above and below the puck. These lanyards pass the mooring line forces through the puck protecting the mooring line where it passes through the puck and split toroid (Figure 3-3).

A thin polyester sleeving holds the 11-channel thermistor chain snugly to the mooring line. The line with thermistor chain is then wound into a line pack and coated with an acrylic mastic to maintain its integrity. The line pack is wound on a mandrel and feeds from the inside out like a ball of twine (Figure 3-4).

The lower line pack is constructed in a similar manner, but is $60-95 \mathrm{~m}$ long. [XMOOR is designed to use up to $125 \mathrm{~m}$ of line - the eight prototypes built to date have used $90 \mathrm{~m}$ of line so that available thermistor chains could be used without modification.] A $55 \mathrm{~m}$ thermistor chain is married to the line beginning $5 \mathrm{~m}$ below the mid-water puck. This chain is also an 11-channel chain, but its thermistors are spaced at $5 \mathrm{~m}$ intervals rather than the $21 / 2 \mathrm{~m}$ intervals in the upper chain. As stated previously, the mooring line is continuous from top to bottom, so both line packs are wound from one shot of the Vectran cable. 


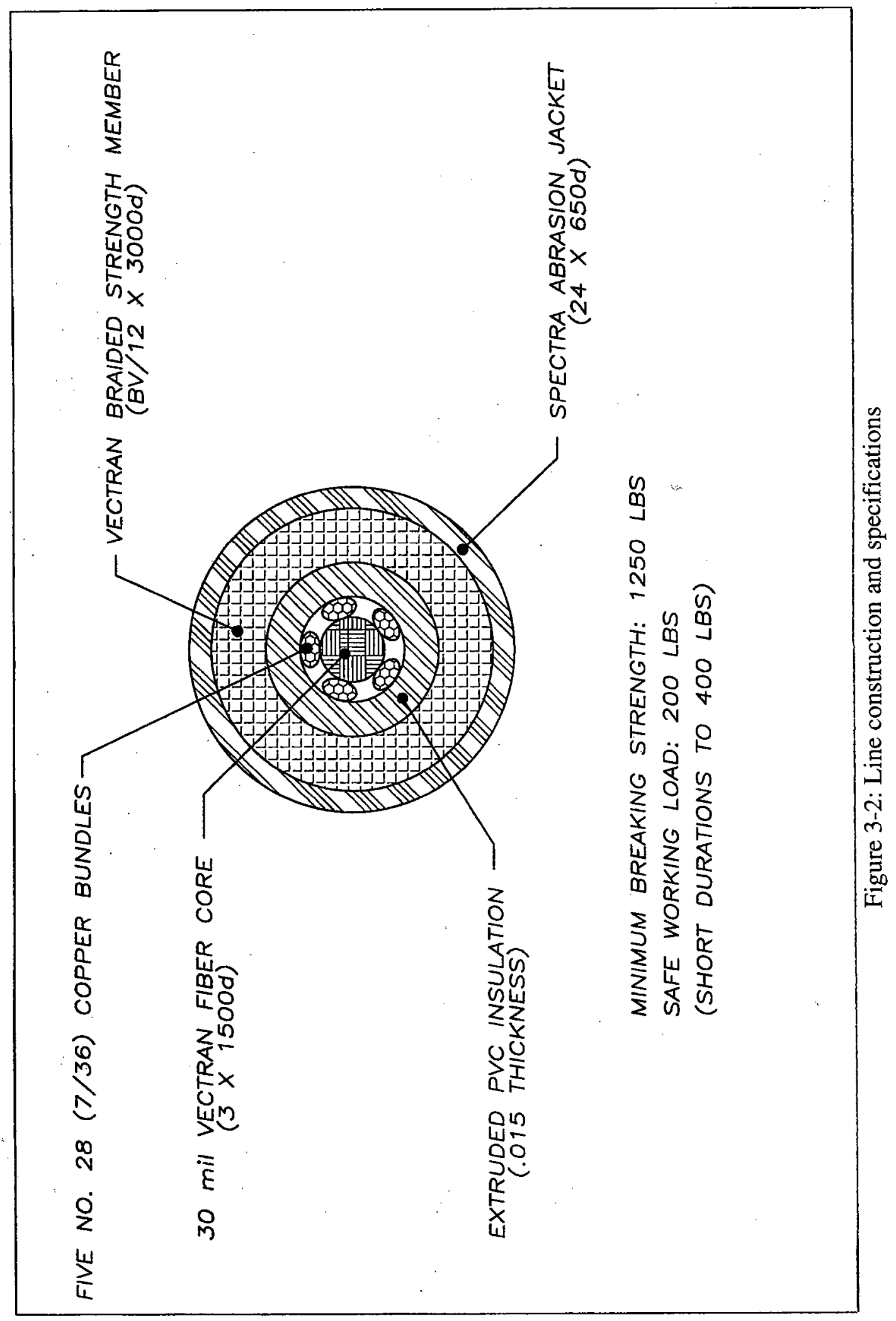



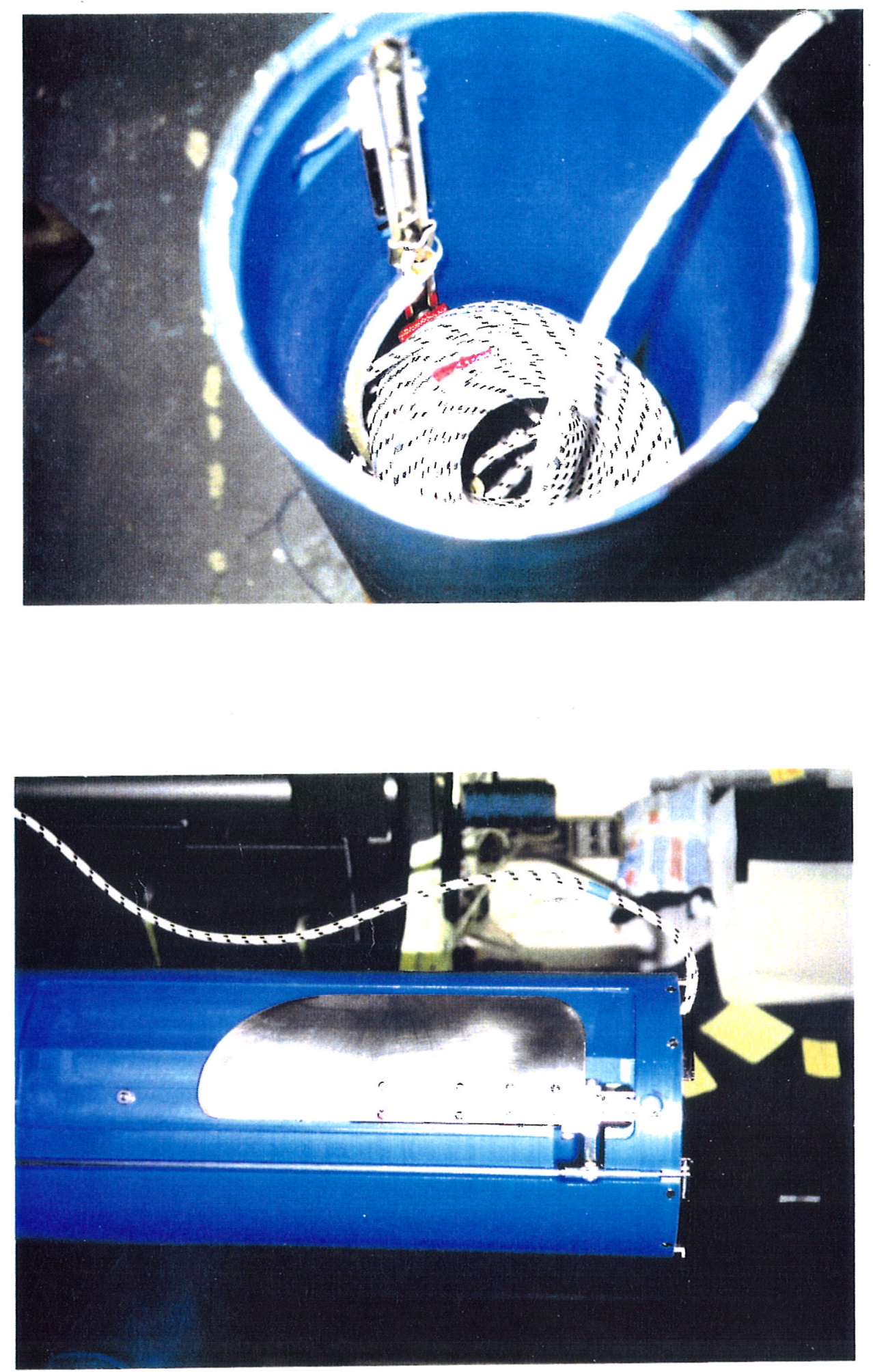

Figure 3-2a: Line canister, lock-up slide and line pack 


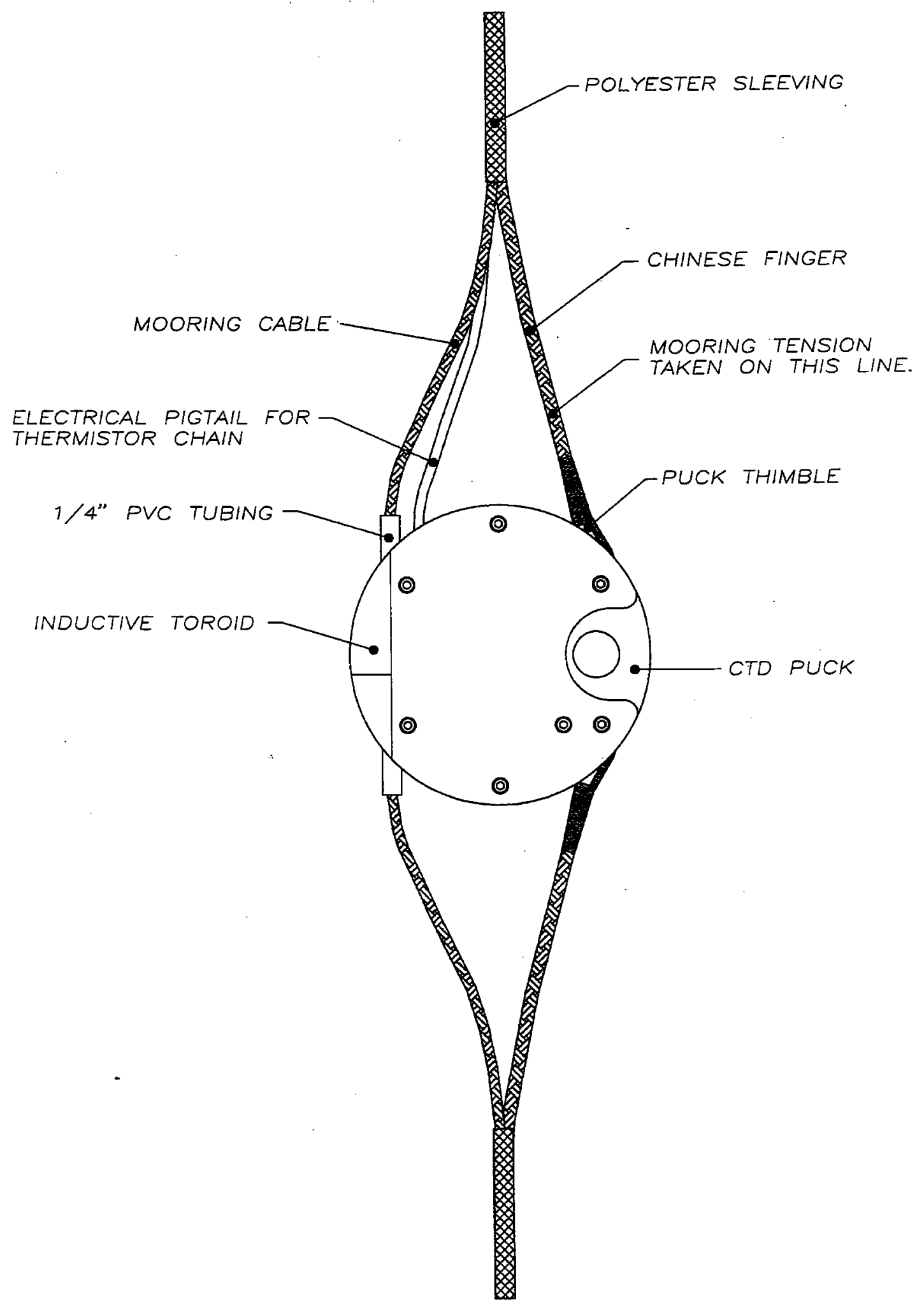

Figure 3-3:Mooring line where it passes through the puck 


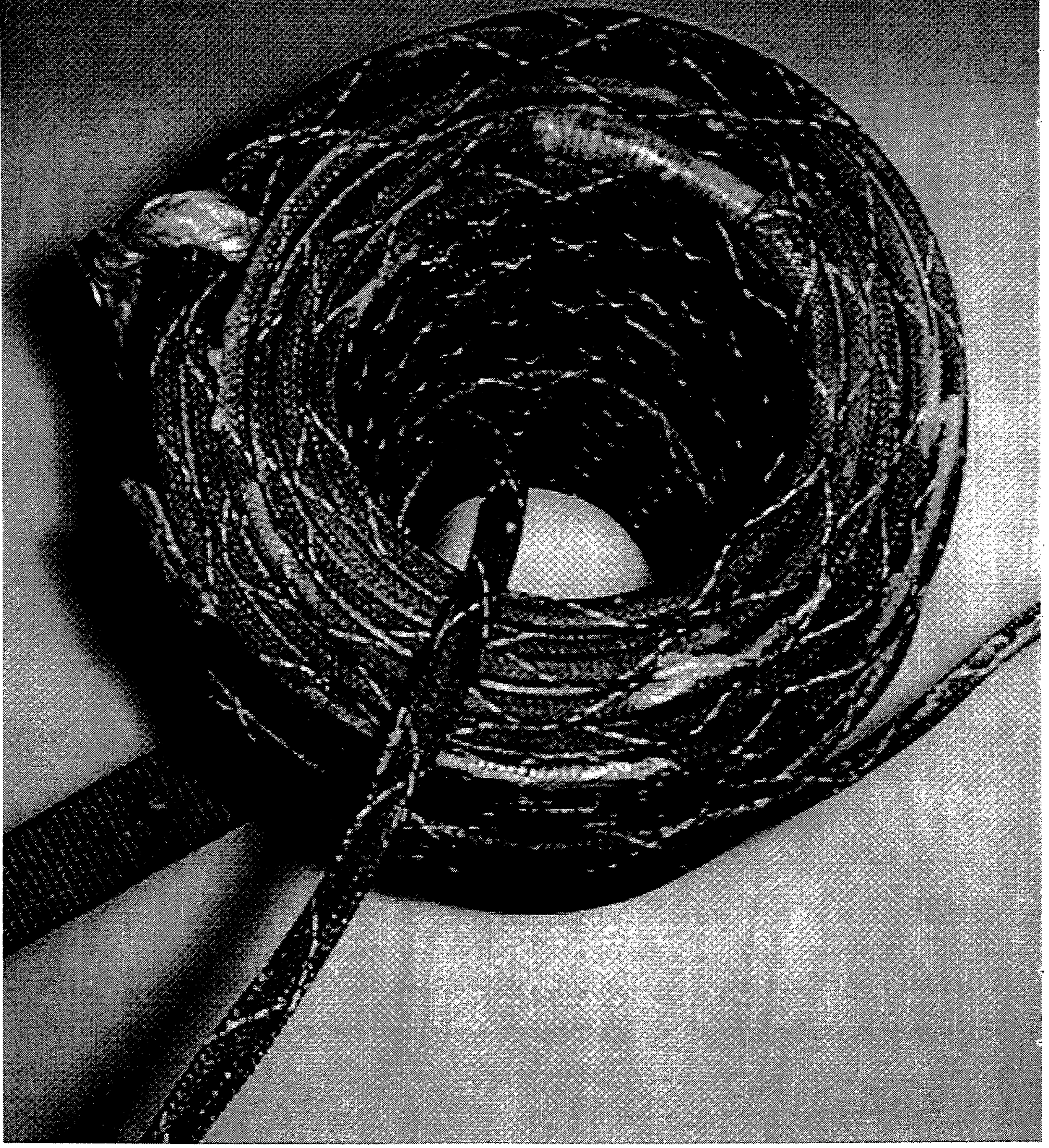

Figure 3-4: Line pack feeding from the center 
Four lock-ups are spliced to the line packs at line lengths of $15,30,60$, and 90 or $125 \mathrm{~m}$. These locations were chosen to provide appropriate scope for a range of water depths, to account for the location of the data collection pucks, and to facilitate assembly. The design will tolerate other choices or more lock-up points, if the requirement exists. The key design consideration for the lock-up points is to provide a strong connection through which all mooring forces pass, without putting undue stress on the mooring line. This is accomplished by splicing short lanyards to the mooring line and terminating the other end of the lanyards to the small stainless steel lock-up links.

\subsection{Data Collection Pucks}

The data collection pucks are self-contained instruments that measure conductivity, temperature, pressure, and eleven channels of thermistor chain data. They contain inductive modems for communication with the system controller located beneath the surface buoy and have a three-month battery supply made up of eight alkaline AA cells. Puck mechanical design is shown in Figure 3-5. Figure 3-6 shows several photographs of the puck and line canisters. The pucks are $15 \mathrm{~cm}$ ( 6 inches) in diameter by $7.6 \mathrm{~cm}$ ( 3 inches) high. They have a split ferrite toroid which can be opened to run the mooring line through the puck. The mid-water puck has a 12-pin feedthrough for the upper thermistor chain and the bottom puck (which remains in the line canister on the bottom) has a similar feedthrough for the lower thermistor chain. The inductive conductivity cell is molded into the puck and has an associated temperature and pressure sensor exposed to the seawater.

Each puck is machined from a single piece of glass-filled delrin. Access to the electronics is available through a cover which has an O-ring seal and is attached with machine screws. The pucks weigh about one pound in water when loaded with electronics and batteries.

\subsection{Anchor Canister}

The anchor canister is an aluminum cylinder with four side panels that are held in place by rings at the top and bottom - similar to a wooden barrel. The top ring attaches the anchor canister to the line canister above it prior to deployment. When the canisters hit the bottom, the drag wing folds down and the canisters disconnect. The sides of the anchor canister are then free to fall away (Figure 3-7).

Inside the anchor canister is $15 \mathrm{~m}$ of $6 \mathrm{~mm}$ ( $1 / 4 \mathrm{inch})$ galvanized chain and the threefluke folding anchor which was developed specifically for XMOOR. The chain has a rated breaking strength of $24 \mathrm{kN}$ ( $5400 \mathrm{lbs}$ ) and provides mooring scope to the system. The chain also provides compliance for wave action and lowers the angle of attack to the anchor. The chain is terminated at its upper end with a shackle to the lock-up guide at the bottom of the line canister and at its lower end to the anchor stock with another shackle. The anchor and chain are deployed by the action of the wind and currents which tend to drag the mooring away from its deployment site. The anchor embeds as 

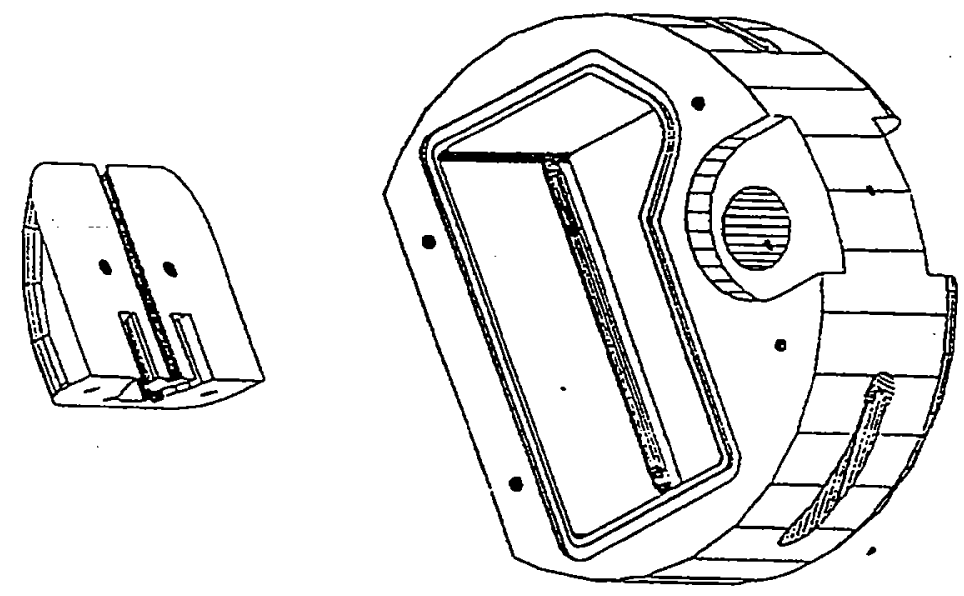

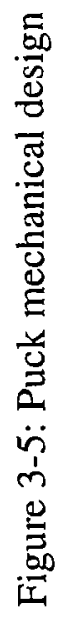



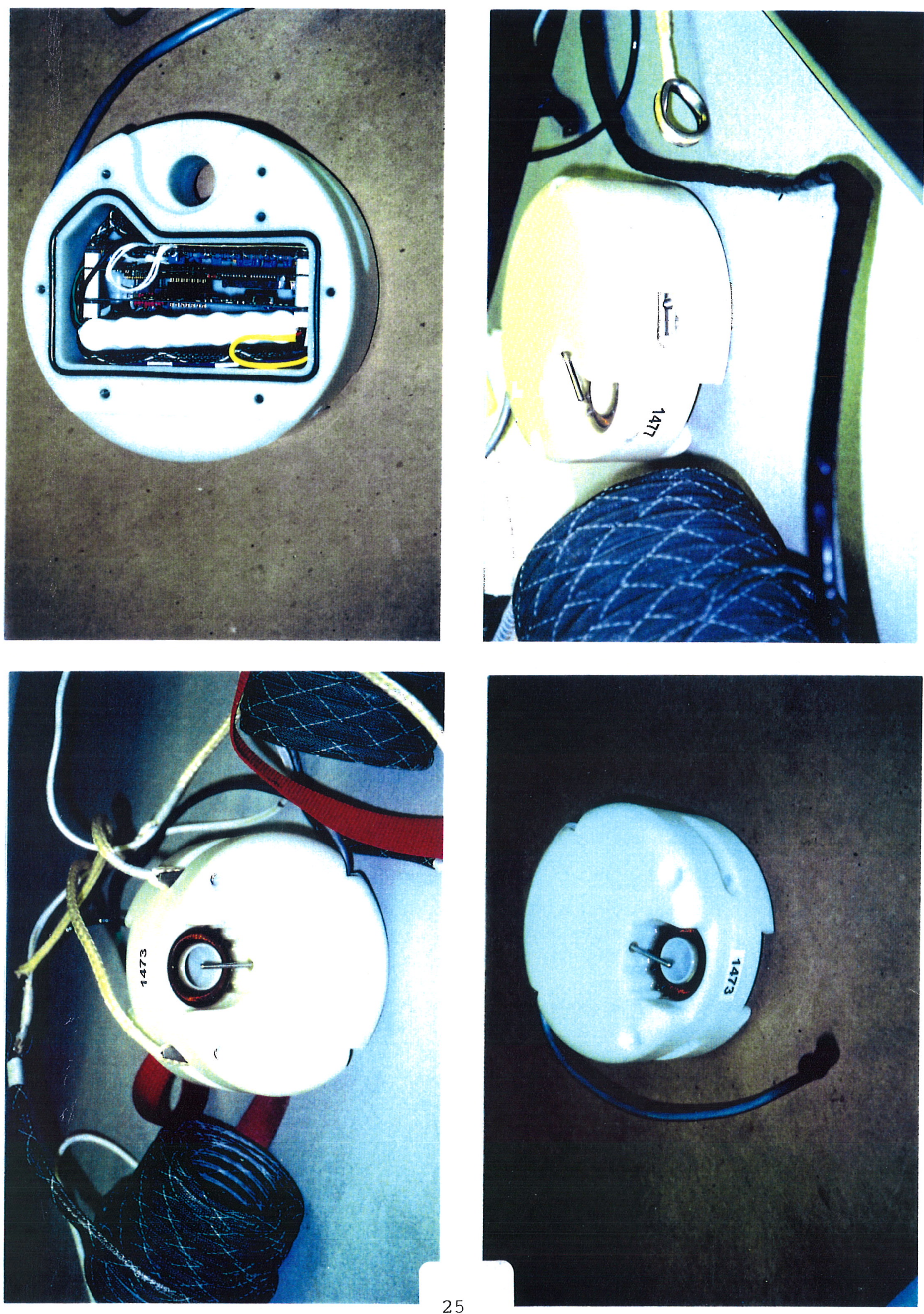

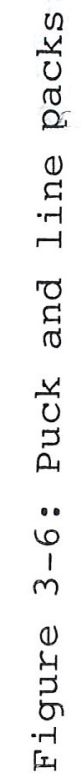




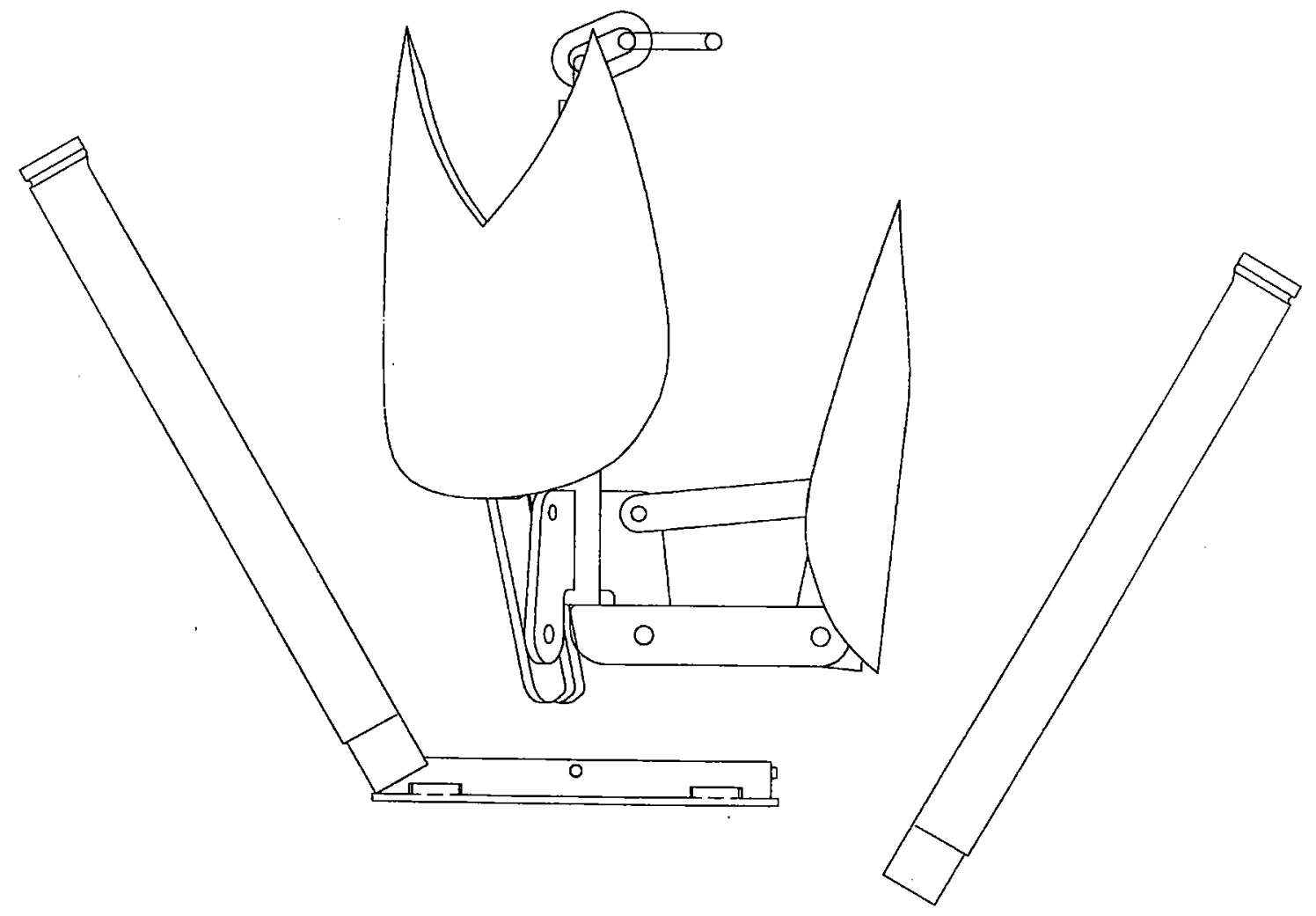

Figure 3-7: Anchor with breakaway canister (two sides shown falling away)

it is dragged. Changing current direction may cause the anchor to drag, but it quickly re-embeds as it moves along the bottom. By using three flukes, the XMOOR anchor avoids the directionality problems associated with Danforth type anchors. It is designed to respond similarly to the Bruce anchor, but provides more holding power than a Bruce anchor sized to fit the XMOOR packaging constraints. Figure 3-8 shows the anchor embedded in the sand. 


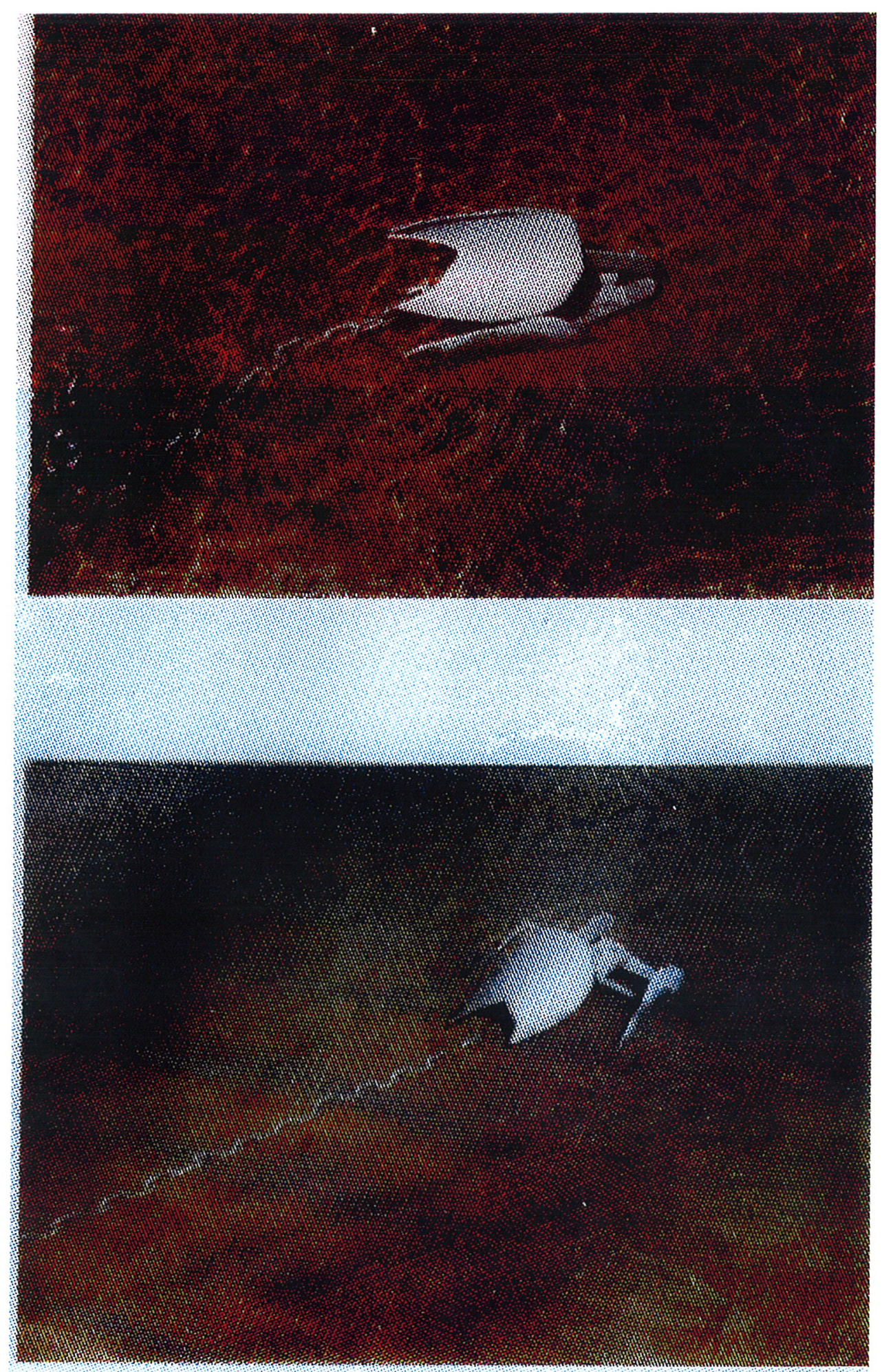

Figure 3-8: XMOOR anchor embedded in sand 


\section{DISCUSSION}

The Expendable Oceanographic Mooring project was an ambitious engineering development whose goal was to design and build a prototype shallow-water, selfdeploying mooring capable of making comprehensive water column measurements for several months. It follows on several earlier attempts to develop self-deploying moorings such as ADOM [6] and incorporates ideas from sonobuoys and small drifting buoys. The designs resulting from the project are sophisticated and simple and they appear to function as designed; however, long-term tests in a range of coastal environments have not yet been carried out so the reliability of several key mechanical systems is still uncertain. Small modifications to the design will likely be necessary to optimize the long-term survivability of the system.

The specific areas in the XMOOR design which involve new design concepts and technical innovations are:

1. Inductive telemetry of water column sensor data to the surface buoy: This technique uses a single conductor to transmit data up the mooring and allows polling of sensors so that multiple instruments can share the single conductor.

2. Vectran mooring line with a single, robust conductor: Vectran is a very high strength synthetic with very low stretch and better resistance to bending failure than Kevlar. The single conductor used for telemetry was constructed by wrapping it around a small Vectran core in a high angle helix. This construction provides improved reliability over typical multi-conductor synthetic lines, especially where they connect to a surface buoy.

3. Self-inflating buoy with 3-month life: Most self-inflating systems use liquid $\mathrm{CO}_{2}$ as an inflation gas. $\mathrm{CO}_{2}$, however, is difficult to contain over long periods since it diffuses through most rubbers. XMOOR uses high pressure nitrogen as an inflation gas to achieve long life with a thin urethane-coated nylon buoy.

4. Lightweight embedment style anchor packaged in small diameter housing: $X M O O R$ requires substantial holding power in strong currents with a variety of bottom types and variable scope. An anchor with folding flukes was developed that works well in most environments.

5. Automatic deployment with self-adjusting mooring scope: The purpose of this feature was to allow an untrained person to take a pre-packaged system into the field and deploy it anywhere in the near-shore region without having any special knowledge of water depth, current profile, or bottom type. No on-site configuration is required and no special deployment equipment is needed. 
6. Miniature CTD with integral inductive modem and 11-sensor thermistor chain: This is the heart of the in-water sensor system and it was developed specifically for the XMOOR project. The thermistor chain was developed for drifting buoys under a separate NRL program and integrated into the CTD system. Falmouth Scientific, Inc., under subcontract to WHOI/NRL, developed the CTD sensor electronics. The inductive modems were originally developed at $\mathrm{WHOI}$ [3] and [4], but were implemented by NRL for the second generation XMOOR prototype.

As more experience is gained with the prototype systems and as specific applications are defined, modifications to the prototype sensor suite, telemetry systems, and data collection systems are anticipated. While the system can support different payloads, the packaging and self-deploying constraints may require substantial engineering modifications to accommodate substantive payload changes.

Besides the issues of size, weight, range of conditions, and lifetime, a final constraint on the XMOOR prototype is cost. Expendable systems need to be inexpensive if they are to be used in large numbers. It should be noted that some of the specifications for XMOOR are seriously at odds with the typical definition of inexpensive - particularly the requirements for CTD measurements at several depths and three-month life. In spite of these difficulties, XMOOR is reasonably inexpensive.

Table 4-1 lists the component prices of the XMOOR mechanical system when ordered in small (8) quantity. Obviously, high volume production techniques have not been utilized to date. A similar list of the electronic components is shown in Table 4-2. The costs associated with mechanical assembly and test are difficult to quantify, but given some experience with the fabrication techniques, several technician days is a reasonable estimate. It remains to be seen whether or not an expendable mooring with a component cost of $\$ 15,000$ will be used as an expendable. With this in mind, XMOOR has been designed to be capable of recovery and refurbishment. Refurbishment consists of re-batterying, replacing worn-out line and chain, and replacing the buoy assembly (if necessary). The systems can then be re-packed and used for considerably less than the cost of replacement. 
Table 4.1: XMOOR Component Costs - Mechanical

\begin{tabular}{|c|c|c|c|}
\hline DESCRIPTION & QUANTITY & UNIT COST & TOTAL COST \\
\hline Surface Buoy w/ 8 Inflators & 1 & $\$ 236.00$ & $\$ 236.00$ \\
\hline Buoy Side Retainers & 4 & $\$ 6.00$ & $\$ 24.00$ \\
\hline Tree Rivets & 8 & $\$ 0.32$ & $\$ 2.56$ \\
\hline Nitrogen Gas Cartridges & 8 & $\$ 15.12$ & $\$ 120.96$ \\
\hline Buoy Retaining Ring & 1 & $\$ 34.00$ & $\$ 34.00$ \\
\hline Electronics Pressure Housing & 1 & $\$ 390.00$ & $\$ 390.00$ \\
\hline Pressure Housing Endcap & 1 & $\$ 312.00$ & $\$ 312.00$ \\
\hline Hex Plug on Housing & 1 & $\$ 6.10$ & $\$ 6.10$ \\
\hline $\begin{array}{l}\text { Seacon Bulkhead Connector } \\
\text { XSA-BC }\end{array}$ & 1 & $\$ 16.10$ & $\$ 16.10$ \\
\hline Seacon pigtail RMA-FS & 1 & $\$ 15.70$ & $\$ 15.70$ \\
\hline Mooring Cable & $410^{\prime}$ & @\$0.64 & $\$ 262.40$ \\
\hline $\begin{array}{l}\text { Polyester Sleeving } 84 \mathrm{n} 1483 \\
\text { Type BXPO16 }\end{array}$ & $410^{\prime}$ & $@ \$ 0.53$ & $\$ 219.31$ \\
\hline Lock-up Hardware & 4 & $\$ 12.50$ & $\$ 50.00$ \\
\hline Lock-up Slide & 4 & $\$ 20.00$ & $\$ 80.00$ \\
\hline 6-Wire Pave Connector & 1 & $\$ 175.00$ & $\$ 175.00$ \\
\hline 12-Wire Pave Connector & 2 & $\$ 240.00$ & $\$ 480.00$ \\
\hline $\begin{array}{l}\text { Coax Epoxy Connector } \\
\text { (antenna) }\end{array}$ & 1 & $\$ 185.00$ & $\$ 185.00$ \\
\hline Ground Lug & 1 & $\$ 44.00$ & $\$ 44.00$ \\
\hline Buoy Endcap & 1 & $\$ 52.00$ & $\$ 52.00$ \\
\hline Buoy Strap Ratining Ring & 1 & $\$ 54.00$ & $\$ 54.00$ \\
\hline Anchor & 1 & $\$ 300.00$ & $\$ 300.00$ \\
\hline Anchor Canistor Side Top & 4 & $\$ 42.00$ & $\$ 168.00$ \\
\hline Anchor Canister Rolled Side & 4 & $\$ 6.00$ & $\$ 24.00$ \\
\hline Anchor Canister Bottom & 1 & $\$ 98.00$ & $\$ 98.00$ \\
\hline
\end{tabular}




\begin{tabular}{|l|c|r|r|}
\hline \multicolumn{1}{|c|}{ DESCRIPTION } & QUANTITY & UNIT COST & TOTAL COST \\
\hline Misc. Hardware & 1 & $\$ 20.00$ & $\$ 20.00$ \\
\hline Anchor Chain & $50^{\prime}$ & $\$ \$ 0.50$ & $\$ 25.00$ \\
\hline Line Canister, Bare Tube & 1 & $\$ 344.00$ & $\$ 344.00$ \\
\hline Lockup Track & 1 & $\$ 20.00$ & $\$ 20.00$ \\
\hline Track Bottom Tab, Welded & 1 & $\$ 45.00$ & $\$ 45.00$ \\
\hline Activator Wing & 1 & $\$ 25.00$ & $\$ 25.00$ \\
\hline Actuator Fixed Piece & 1 & $\$ 38.10$ & $\$ 38.10$ \\
\hline Accuator Moving Piece & 1 & $\$ 78.70$ & $\$ 78.70$ \\
\hline Accuator Arm & 1 & $\$ 33.00$ & $\$ 33.00$ \\
\hline Accuator Lock-up Spring & 1 & $\$ 87.00$ & $\$ 87.00$ \\
\hline Pushrod, Top and Bottom & 1 & $\$ 15.45$ & $\$ 15.45$ \\
\hline Upper Pushrod End & 1 & $\$ 15.30$ & $\$ 15.30$ \\
\hline Lower Pin Puller & 1 & $\$ 16.10$ & $\$ 16.10$ \\
\hline Top Ring, to Buoy & 2 & $\$ 116.00$ & $\$ 232.00$ \\
\hline Bottom Ring, to Anchor Can & 1 & $\$ 155.00$ & $\$ 155.00$ \\
\hline Spring Retainer Ring & 2 & $\$ 8.80$ & $\$ 17.60$ \\
\hline TOTAL & & & $\$ 4,516.38$ \\
\hline
\end{tabular}


Table 4-2: XMOOR Component Costs - Electronics/Sensors

\begin{tabular}{|l|r|r|r|}
\hline \multicolumn{1}{|c|}{ COMPONENT } & QUANTITY & \multicolumn{1}{c|}{ COST } & \multicolumn{1}{c|}{ TOTAL COST } \\
\hline Barometric pressure sensor & 1 & $\$ 23.00$ & $\$ 23.00$ \\
\hline Air Temperature & 1 & $\$ 39.00$ & $\$ 39.00$ \\
\hline Thermistor Chain & 2 & $\$ 1500.00$ & $\$ 1500.00$ \\
\hline $\begin{array}{l}\text { CTD Puck w/conductivity, } \\
\text { temperature, pressure, } \\
\text { modem, batteries }\end{array}$ & 2 & $\$ 1,950.00$ & $\$ 3,900.00$ \\
\hline Surface Controller & 1 & & $\$ 1,327.00$ \\
\hline GINA Model 5000 & 1 & 500.00 & 500.00 \\
\hline SEIMAC Smart CAT II & 1 & $\$ 1,000.00$ & $\$ 1,000.00$ \\
\hline Puck Controller Board & 2 & $\$ 159.00$ & $\$ 318.00$ \\
\hline Batteries & 21 & $\$ 2.00$ & $\$ 42.00$ \\
\hline $\begin{array}{l}\text { Approximate Total } \\
\text { Electronics/Sensors }\end{array}$ & & & $\$ 10,149.00$ \\
\hline $\begin{array}{l}\text { Approximate Total } \\
\text { XMOOR Prototype }\end{array}$ & & & $\$ 14,665.00$ \\
\hline
\end{tabular}




\section{REFERENCES}

[1] J. Boyd, R. Burnes, B. Bricker, and D. E. Frye, "An expendable, self-deploying coastal mooring: telemetry and sensors," presented at AGU/ASLO Ocean Sciences Meeting, San Diego, CA, February 12-16, 1996.

[2] Frye, Daniel E. and Janice Boyd, "Expendable Oceanographic Mooring XMOOR," Sea Technology, August 1996, pp 61-65.

[3] R. Eastwood, T. Dickey, J. Kemp, and D. Frye, "Inductive telemetry for ocean moorings: operational experience," presented at AGU/ASLO Ocean Sciences Meeting, San Diego, CA, February 12-16, 1996.

[4] Daniel Frye, Steve Merriam, Bob Eastwood, John Kemp, Neil McPhee, Steve Liberatore, Ed Hobart, Alex Bocconcelli, and Susan Tarbell, "Atlantic Long-Term Oceanographic Mooring (ALTOMOOR)," WHOI Technical Rpt. WHOI 96-02, May 1996.

[5] Daniel Frye, "Surface telemetry mooring - two extremes," presented ONR/MTS Buoy Workshop, San Diego, CA, March 27-28, 1996.

[6] L. W. Bonde, D. B. Dillon, E. J. Softley, R. Walden, H. Berteaux, and T. Popp, "Air Deployed Oceanographic Mooring (ADOM) - AB1034," Proceedings, Oceans '83, San Francisco, CA, Aug. 29 - Sept. 1, 1983.

[7] Donald A. Moller, "A computer program for the design and static analysis of single-point subsurface mooring systems: NOYFB," WHOI Tech. Rpt. WHOI 7659, June 1976. 


\section{APPENDICES}

This section contains three appendices which provide:

6.1 Mechanical Drawings

6.2 Selected Model Runs

6.3 Test Reports

Appendix 6.2, Selected Model Runs, shows how XMOOR responds to the current drag associated with typical coastal current profiles. The model used, NOYFB [7], is a static model which computes the mooring shape based on standard values for component drag coefficients, weights, and frontal areas. Wave forcing is not considered. 


\subsection{Mechanical Drawings}

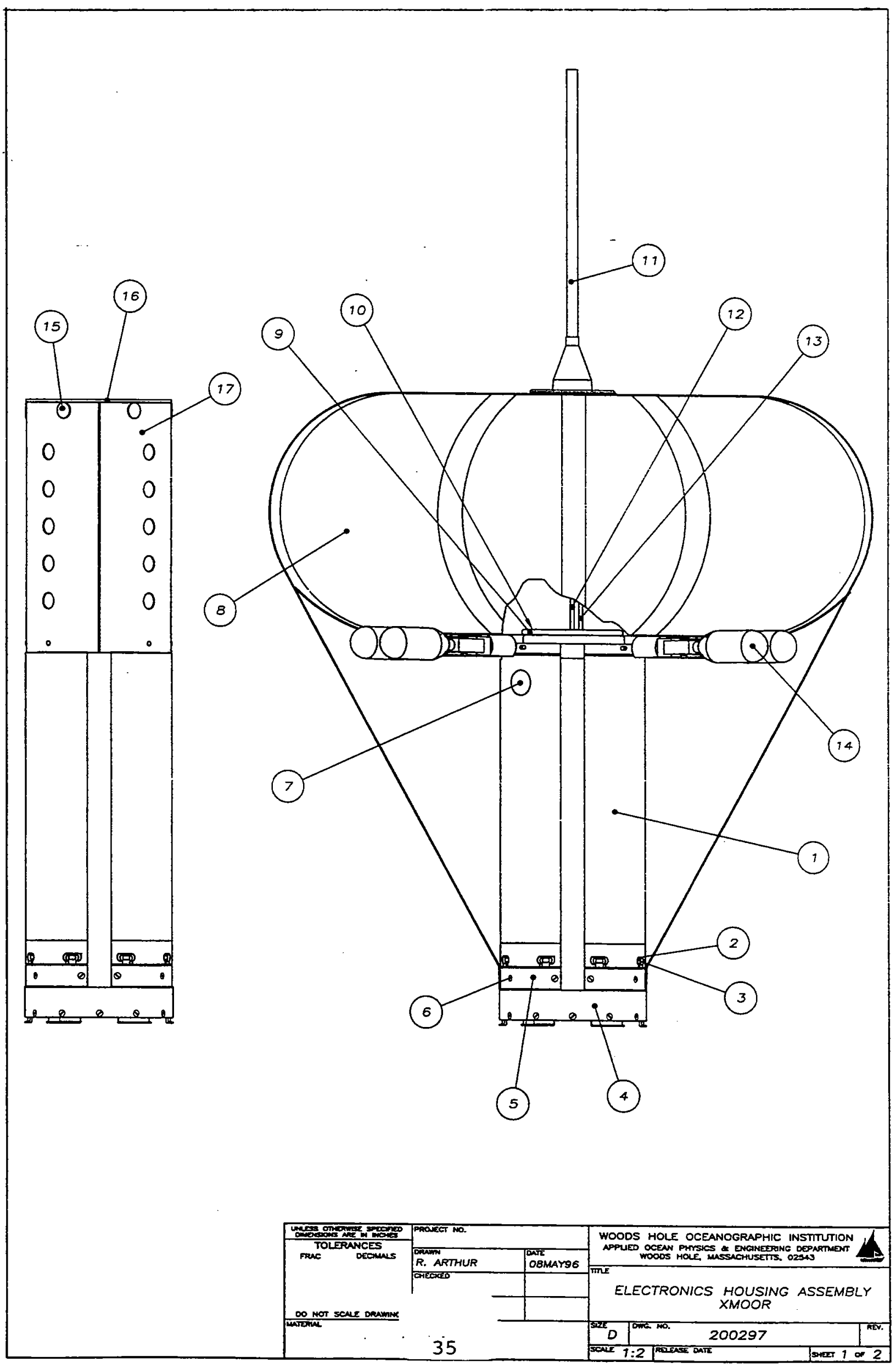




\begin{tabular}{|c|c|c|c|}
\hline & & & \\
\hline & & & \\
\hline & & & \\
\hline & & & \\
\hline & & & \\
\hline & & & \\
\hline & & & \\
\hline & & & \\
\hline & - & - & \\
\hline & & & \\
\hline & & & \\
\hline & & & \\
\hline & & & \\
\hline & & & \\
\hline & & & \\
\hline & & & \\
\hline & & & \\
\hline & & & \\
\hline & & & \\
\hline & & & \\
\hline 17 & 200287 & BUOY PANEL RETAINER & 4 \\
\hline 16 & 200284 & BUOY ENDCAP & 1 \\
\hline 15 & MCMASTER CARR 90221A116 & TREE RIVET, $1 / 4$ HOLE DIA., $.090-.350$ GRIP & 8 \\
\hline 14 & LELAND $52053 \mathrm{N2}$ & NITROGEN GAS CARTRIDGE, 74CC, 30OOPSI & 8 \\
\hline 13 & $\begin{array}{l}S P 8 / 500-E-80-1- \\
R G-174 / U-24-24\end{array}$ & PAVE COAX EPOXY BULKHEAD CONNECTOR & 1 \\
\hline 12 & $S P 6-E-80-6-P C 28-24-24$ & PAVE 6 WIRE EPOXY BULKHEAD CONNECTOR & 1 \\
\hline 11 & & ANTENNA ASSEMBLY & 1 \\
\hline 10 & & $1 / 4-20 \times 3 / 4$ SLOTTED FLT HD SCREW, S.S. & 4 \\
\hline 9 & 200259 & BUOY RETAINING RING & 1 \\
\hline 8 & 200258 & XMOOR INFLATABLE BUOY & 1 \\
\hline 7 & CAJON SS-8-HPST & 3/4-16 SAE HOLLOW HEX PLUG, S.S. & 1 \\
\hline 6 & & $6-32 \times 3 / 8$ SLOTTED FLAT HD SCREW, S.S. & 8 \\
\hline 5 & 200288 & BUOY STRAP RETAINING RING & 1 \\
\hline 4 & 200295 & ENDCAP ASSEMBLY & 1 \\
\hline 3 & & $10-32 \times 1$ SOC CAP HEAD SCREW, S.S. & 8 \\
\hline 2 & & NO. 10 LOCK WASHER, STAINLESS STEEL & 8 \\
\hline 1 & 200256 & ELECTRONICS PRESSURE HOUSING & 1 \\
\hline ITEM & PART OR DWG. NO. & DESCRIPTION & QTY \\
\hline PROJECT & NO./DESCRIPTION & $\begin{array}{l}\text { WOODS HOLE OCEANOGRAPHIC INSTITUTION } \\
\text { APPLLED OCEAN PHYSICS \& ENGINEERING DEPARTMENT } \\
\text { WOODS HOLE, MASSACHUSETIS, O2543 }\end{array}$ & $\Delta$ \\
\hline $\begin{array}{c}\text { DRAWN } \\
\text { R. }\end{array}$ & & DATE & \\
\hline CHECKEL & & ELECTRONICS HOUSING ASSEMB & \\
\hline & & & REV. \\
\hline APPROVE & & 200297 & REV. \\
\hline & & SHEET 2 & of 2 \\
\hline
\end{tabular}




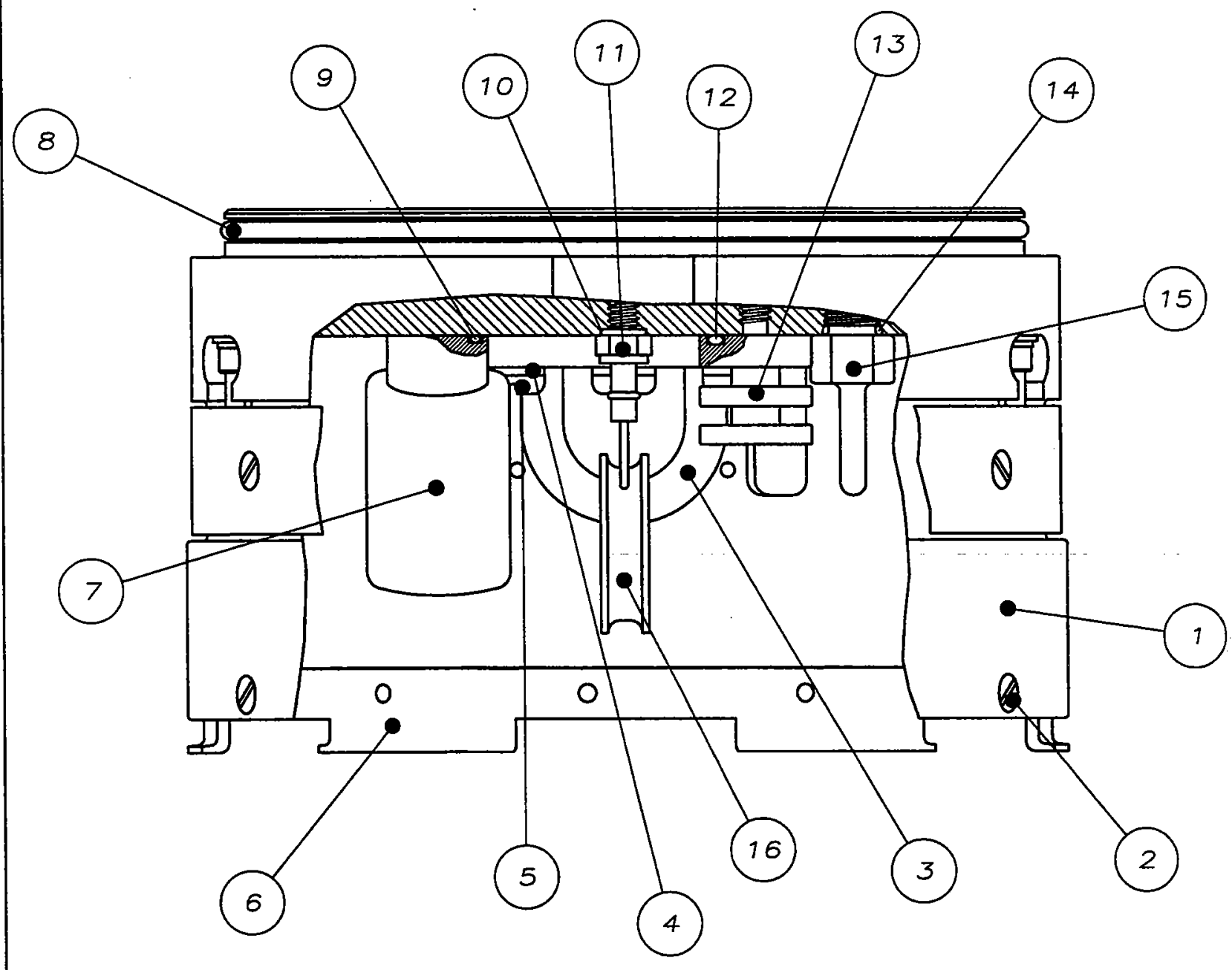

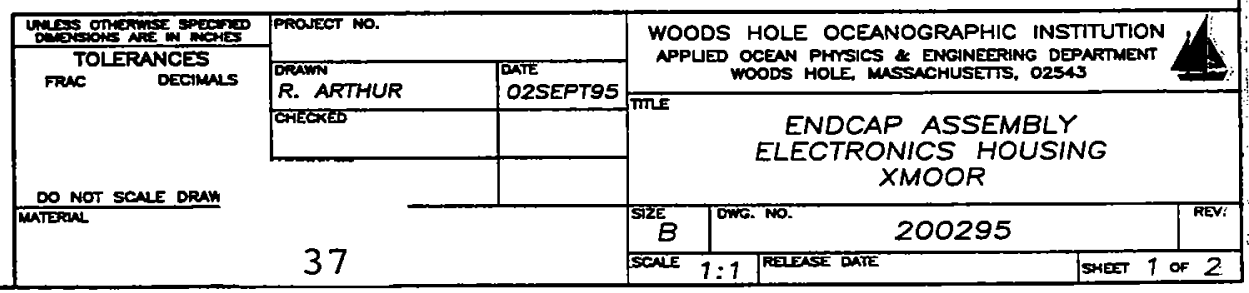




\begin{tabular}{|c|c|c|c|}
\hline & & & \\
\hline & & & \\
\hline & & & \\
\hline & & & \\
\hline & & & \\
\hline & & & \\
\hline & & & \\
\hline & & & \\
\hline & $\cdots$ & & \\
\hline & & & \\
\hline & & & \\
\hline & & & \\
\hline & & & \\
\hline & & & \\
\hline & & & \\
\hline & & & \\
\hline & & & \\
\hline & & & \\
\hline & & & \\
\hline & & & \\
\hline 16 & MCMASTER-CARR $3634 T 71$ & THIMBLE, STAINLESS STEEL & 1 \\
\hline 15 & $200250 B$ & HOUSING, THERMISTOR & 1 \\
\hline 14 & & 3-904 O-RING, BUNA $N, 70$ DUROMETER & 1 \\
\hline 13 & $200285 B$ & GROUND LUG, SEAWATER & 1 \\
\hline 12 & & 2-112 O-RING, BUNA N, 70 DUROMETER & 1 \\
\hline 11 & & MECCA BULKHEAD CONNECTOR & 1 \\
\hline 10 & & 2-009 O-RING, BUNA N, 70 DUROMETER & 1 \\
\hline 9 & & 2-014 O-RING, BUNA N, 70 DUROMETER & 1 \\
\hline 8 & & 2-258 O-RING, BUNA N, 70 DUROMETER & 1 \\
\hline 7 & FALMOUTH SCIENTIFIC & CONDUCTIVITY SENSOR & 1 \\
\hline 6 & 01140111 & BREAKAWAY COLLAR & 1 \\
\hline 5 & & $1 / 4-20 \times 1$ IN. SLOTTED PAN HD, S.S. & 6 \\
\hline 4 & & $1 / 4$ LOCK WASHER, STAINLESS STEEL & 6 \\
\hline 3 & 01121200 & TOP TERMINATION WELDMENT & 1 \\
\hline 2 & & $6-32 \times 3 / 8$ SLOTTED FLAT HD SCREW, S.S. & 12 \\
\hline 1 & 200281 & ENDCAP, BOTTOM & 1 \\
\hline ITEM & PART OR DWG. NO. & DESCRIPTION & QTY \\
\hline$\overline{\text { PROJECT }}$ & NO./DESCRIPTION & $\begin{array}{l}\text { WOODS HOLE OCEANOGRAPHIC INSTITUTION } \\
\text { APPLIED OCEAN PHYSICS \& ENGINERRING DEPARTMENT } \\
\text { WOODS HOLE, MASSACHUSETIS, O2543 }\end{array}$ & \\
\hline DRAWN & ARTHUR & ENDCAP ASSEMBLY & \\
\hline CHECKED & & XMOOR & \\
\hline APPROVE & & \begin{tabular}{l|l}
${ }_{\mathrm{E}} \mathrm{A}$ & DWG. NO.
\end{tabular} & REV. \\
\hline & & SHEET 2 & or 2 \\
\hline
\end{tabular}




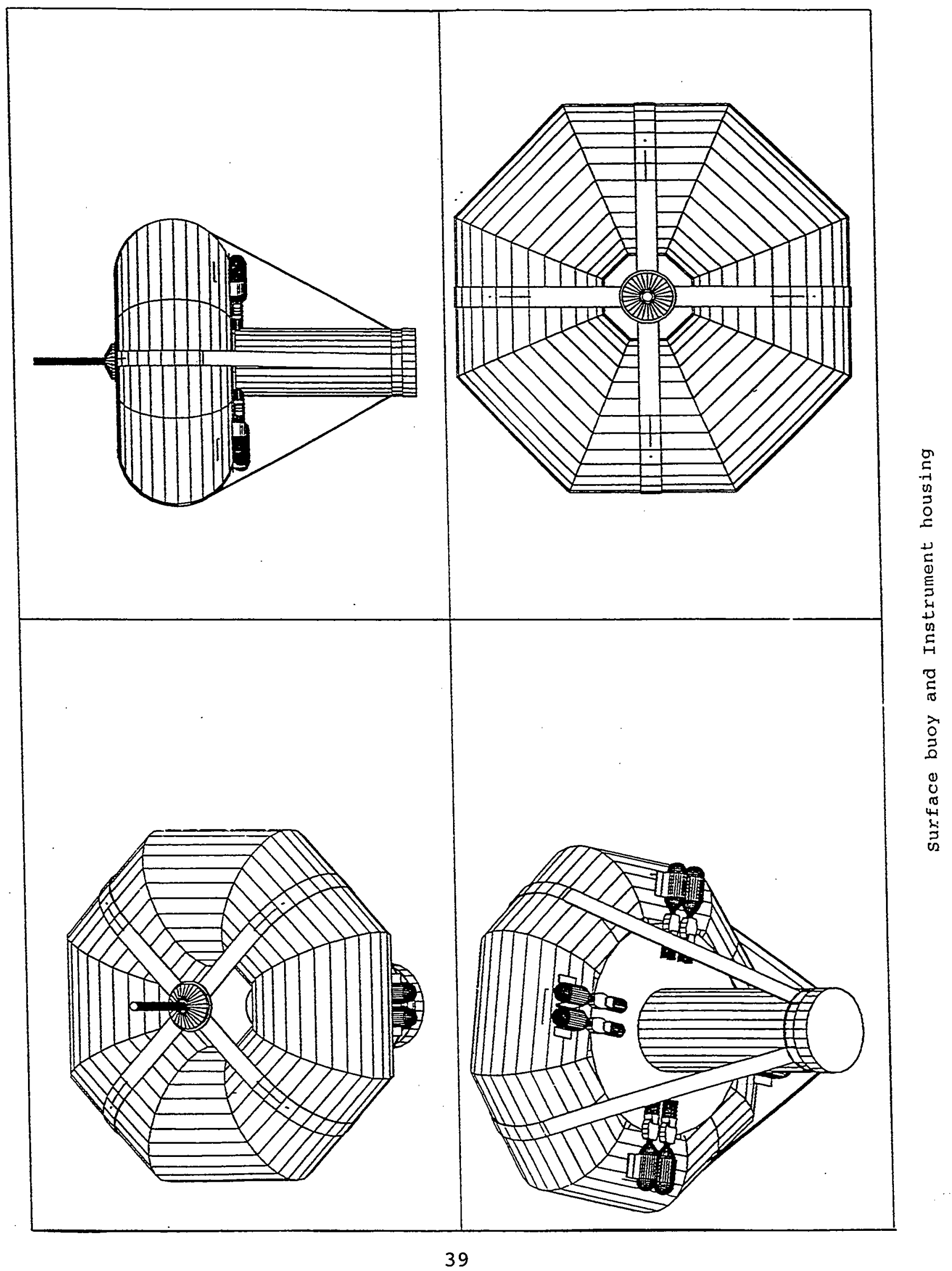




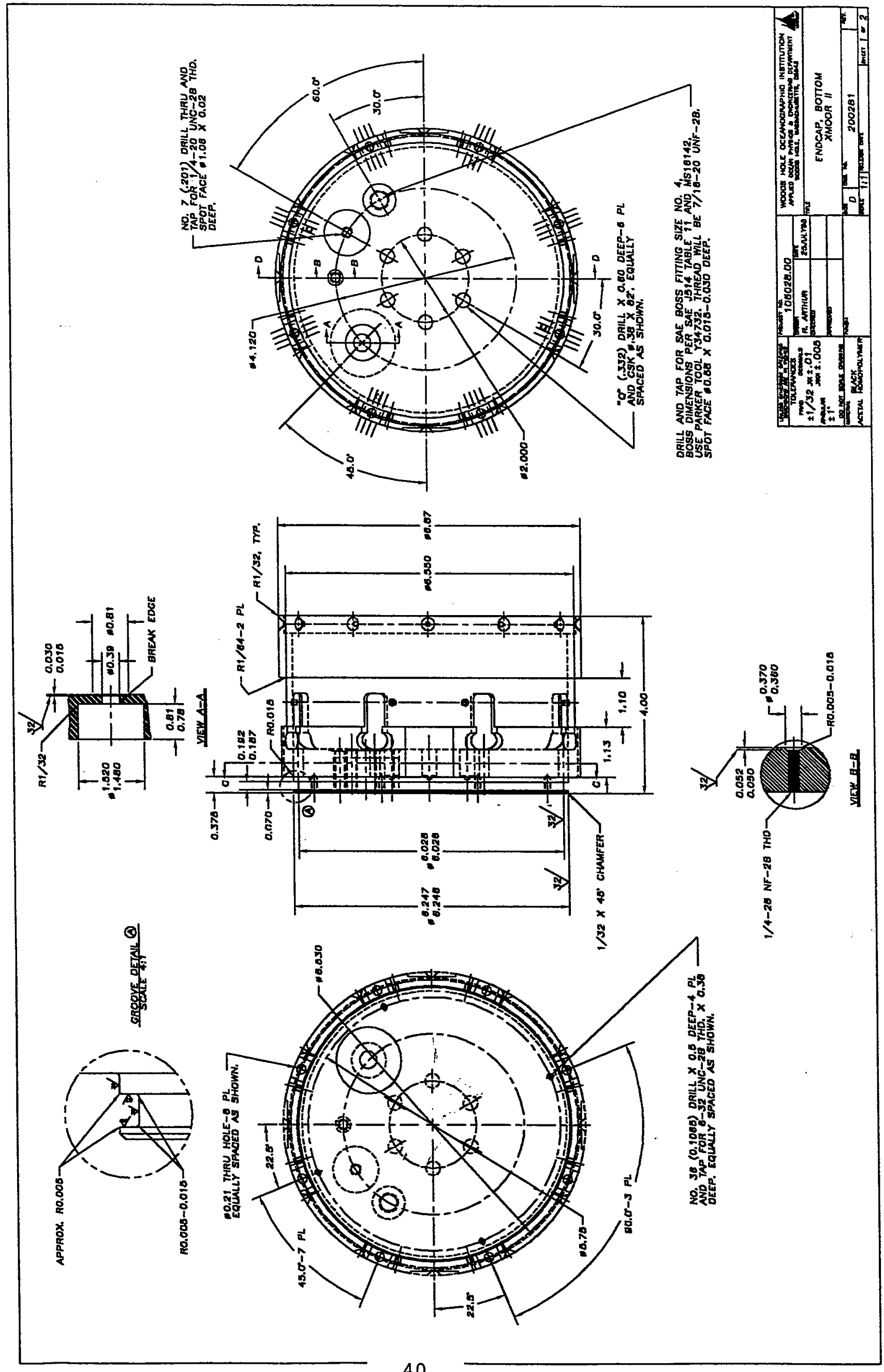




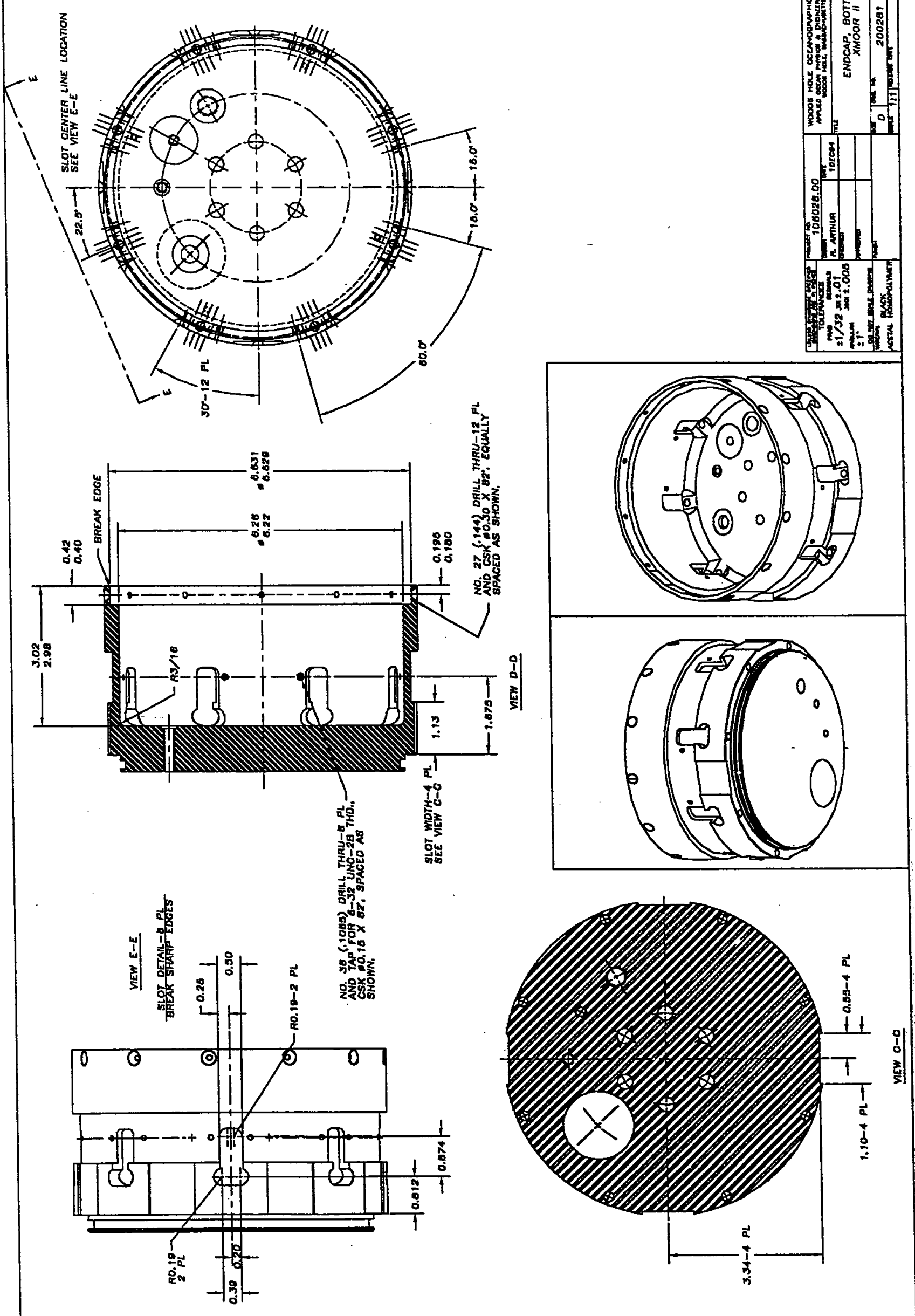



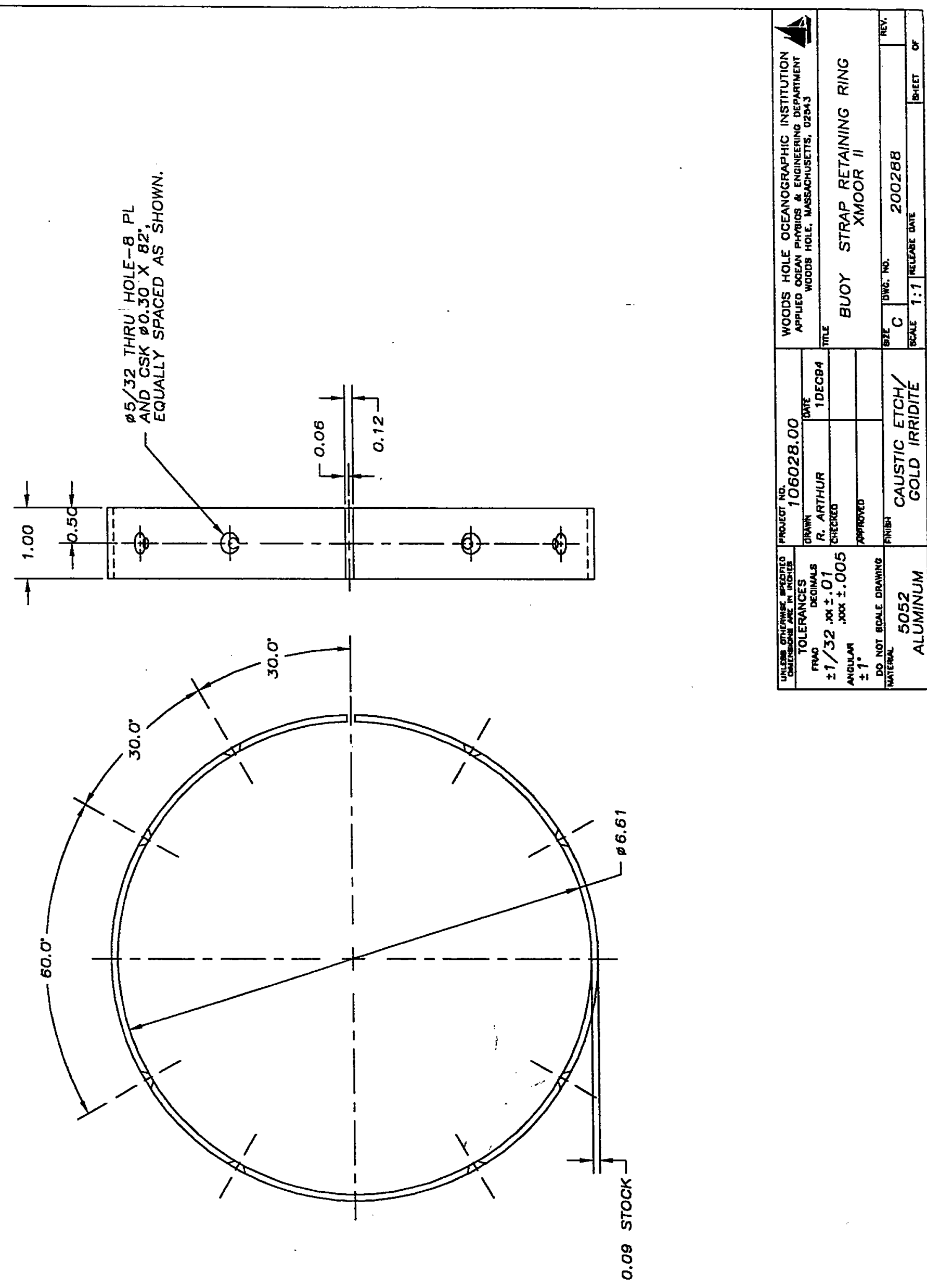


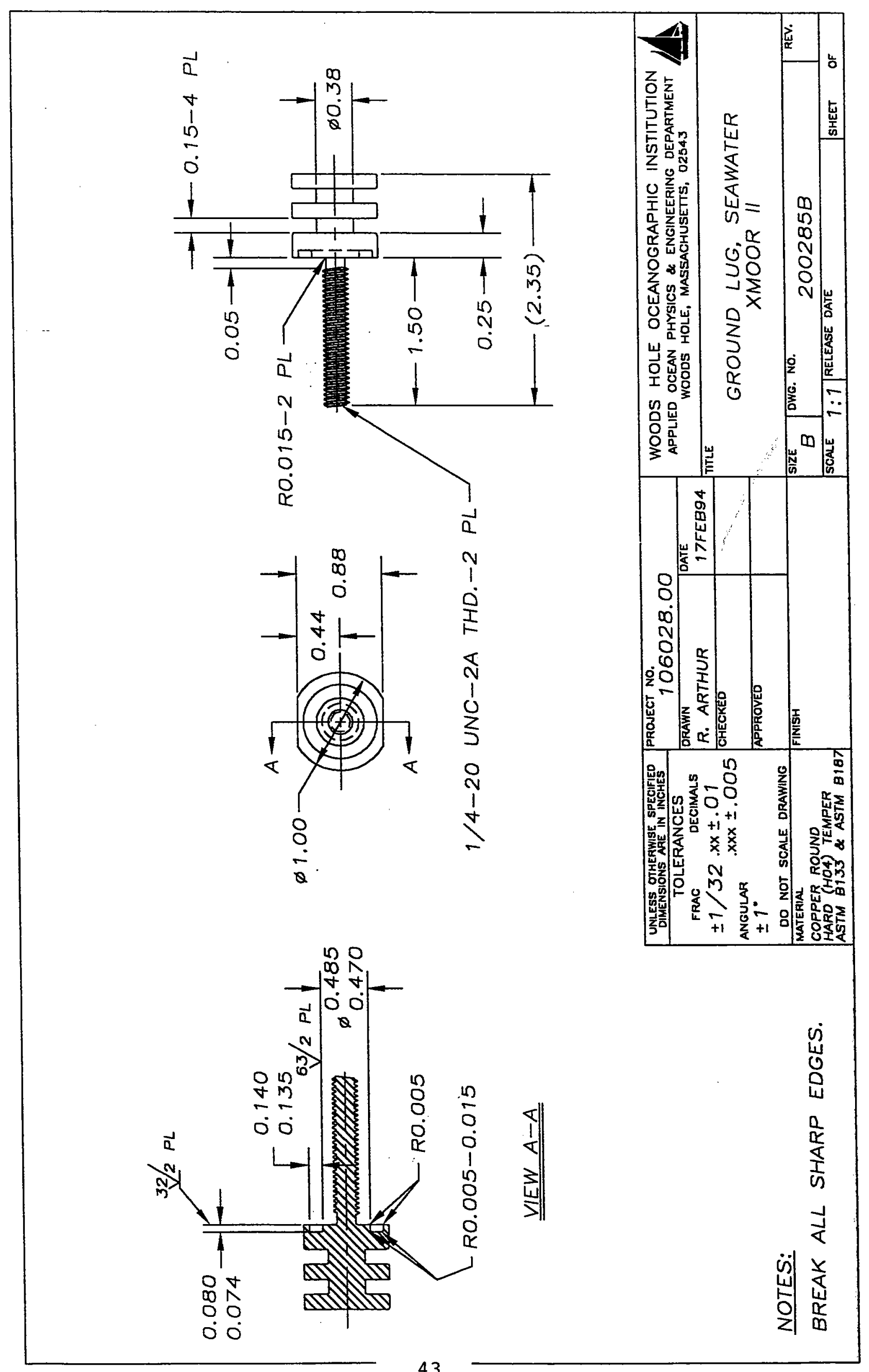




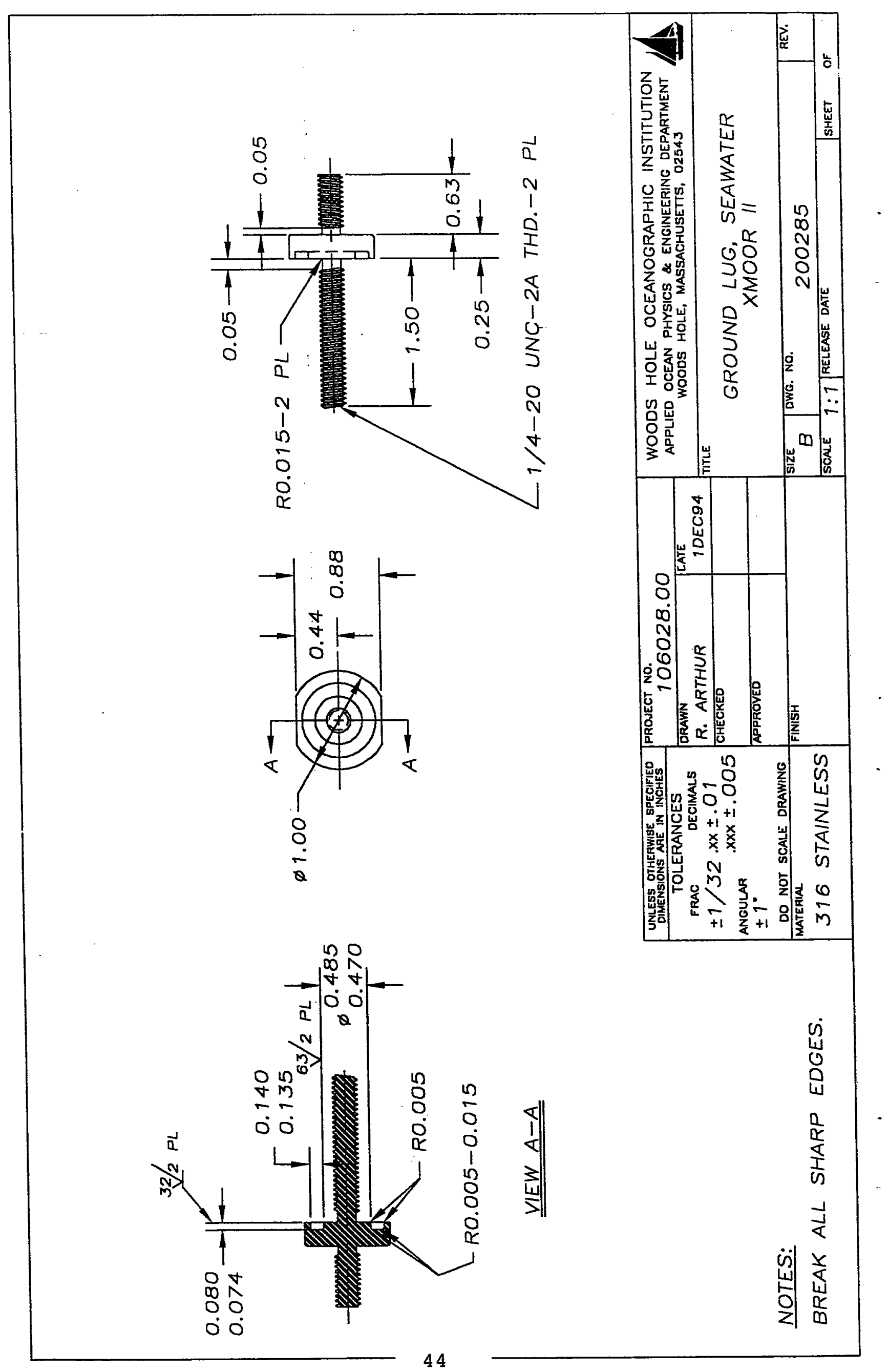




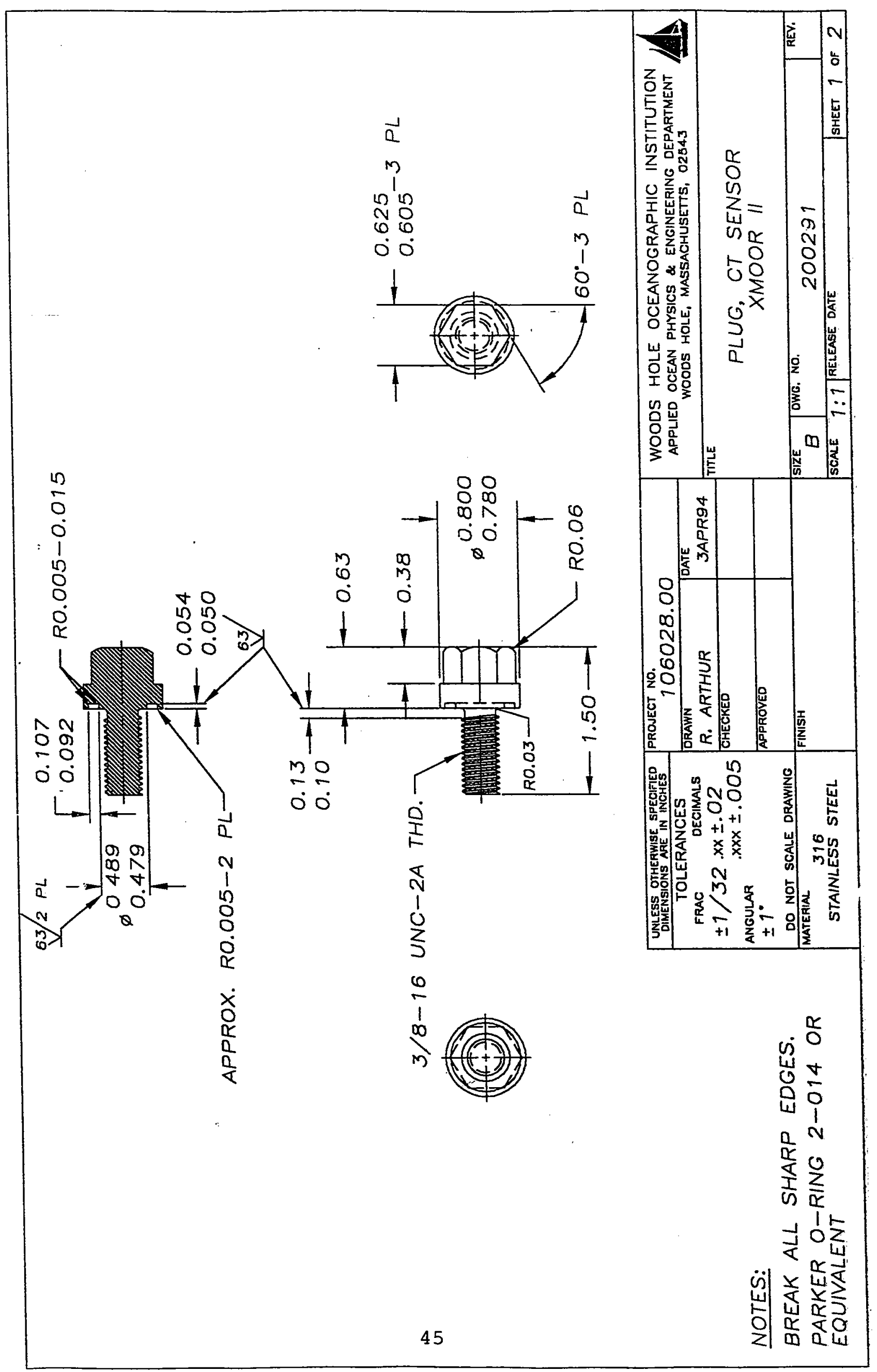




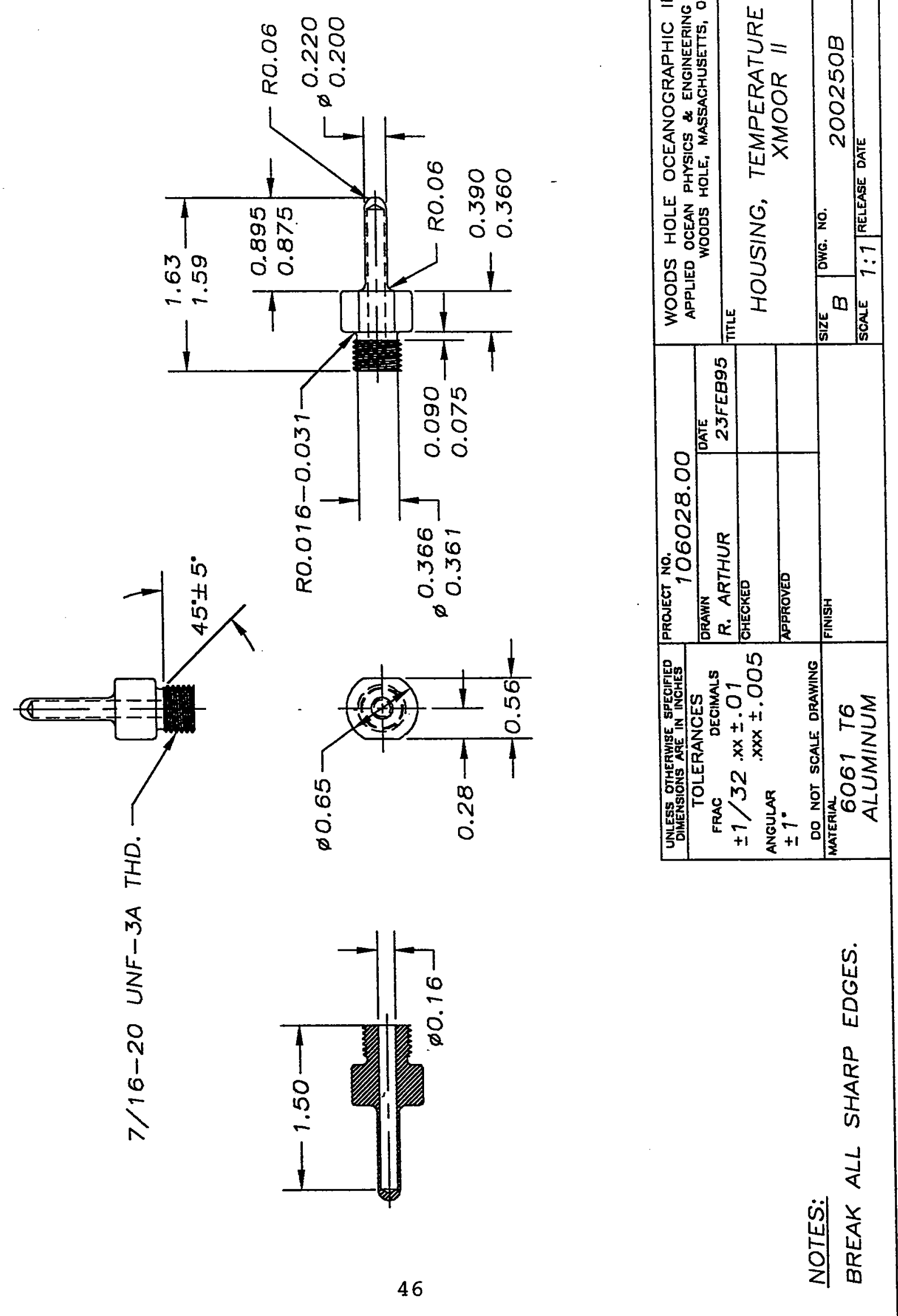




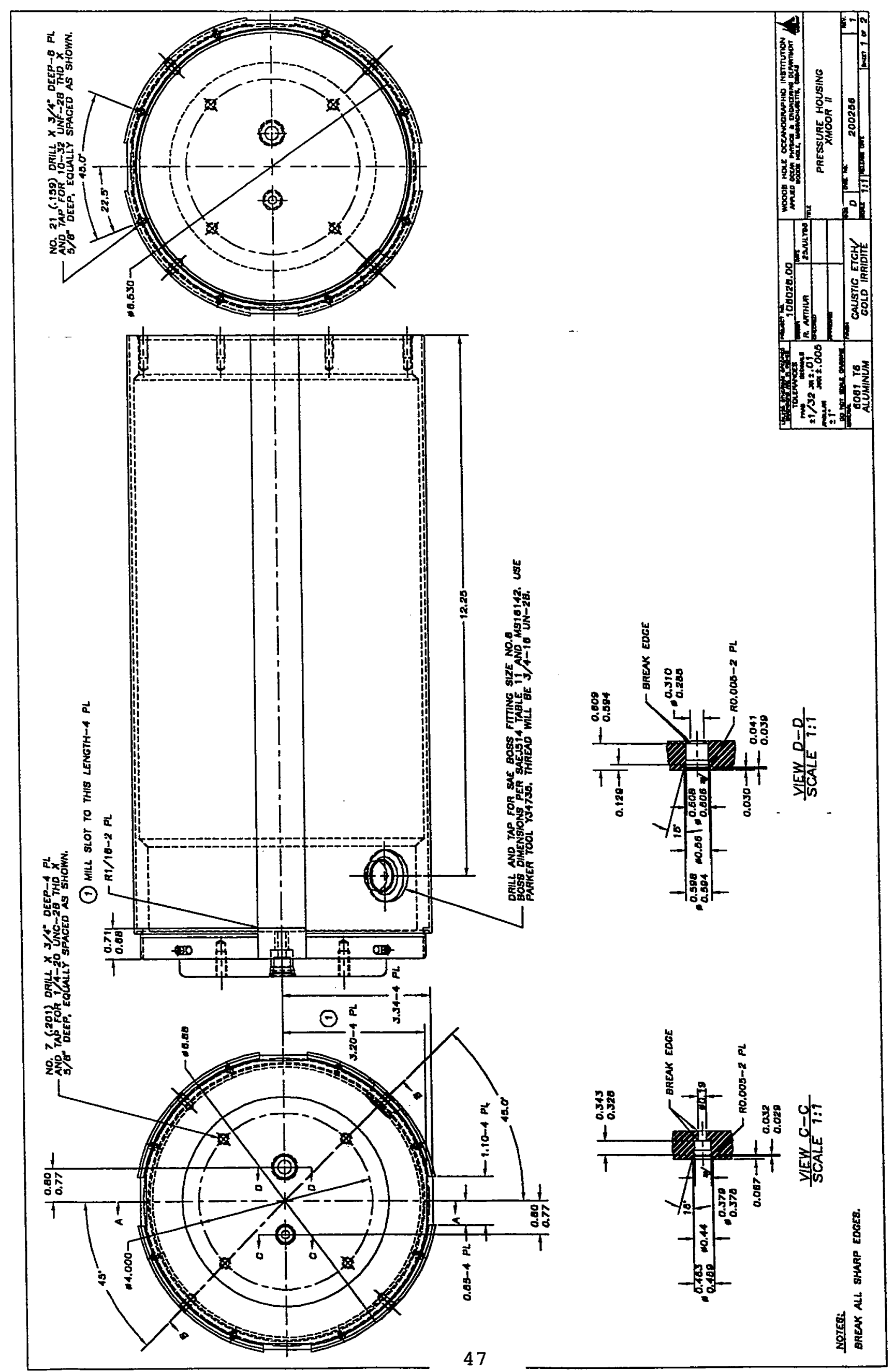




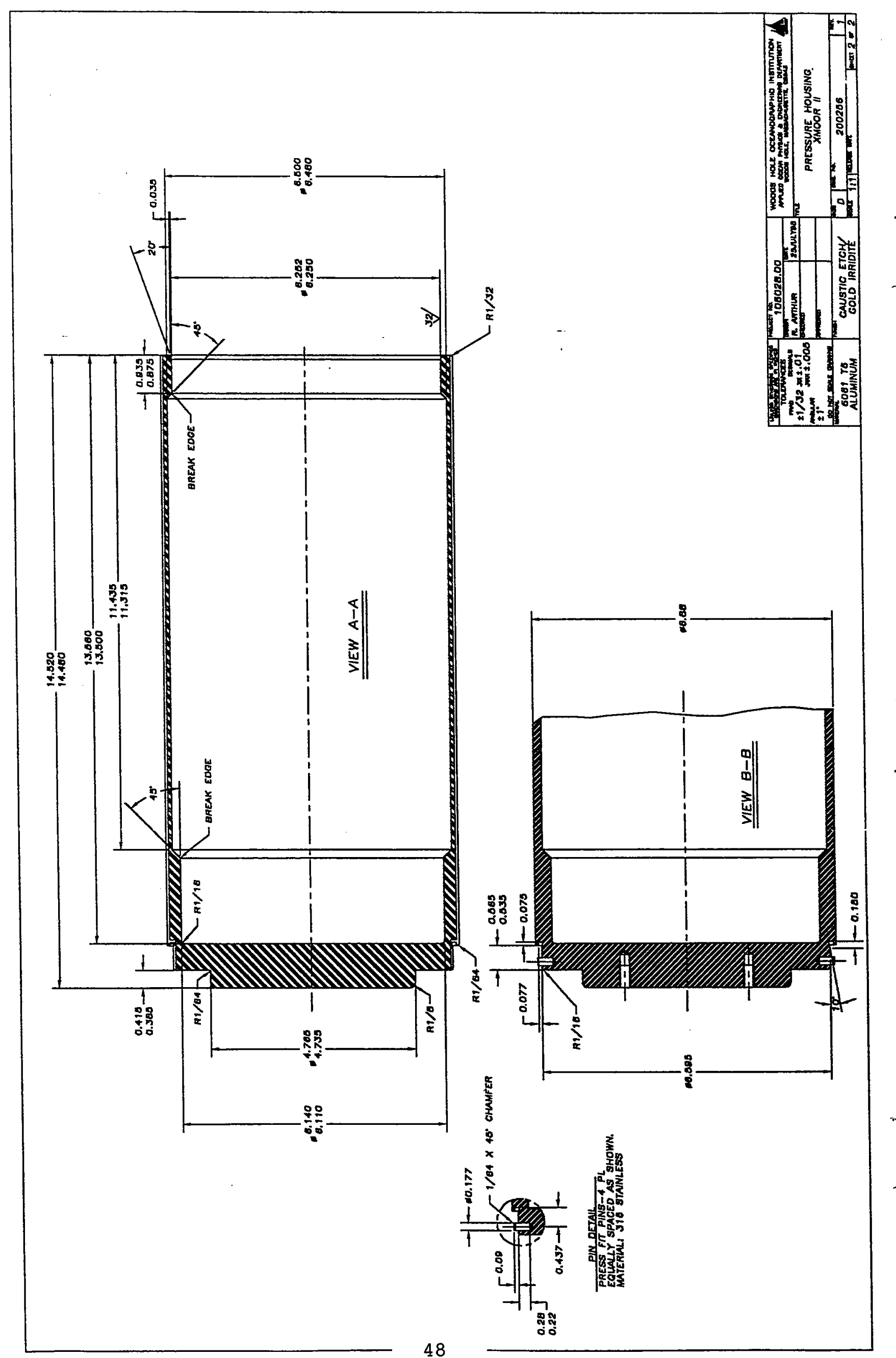



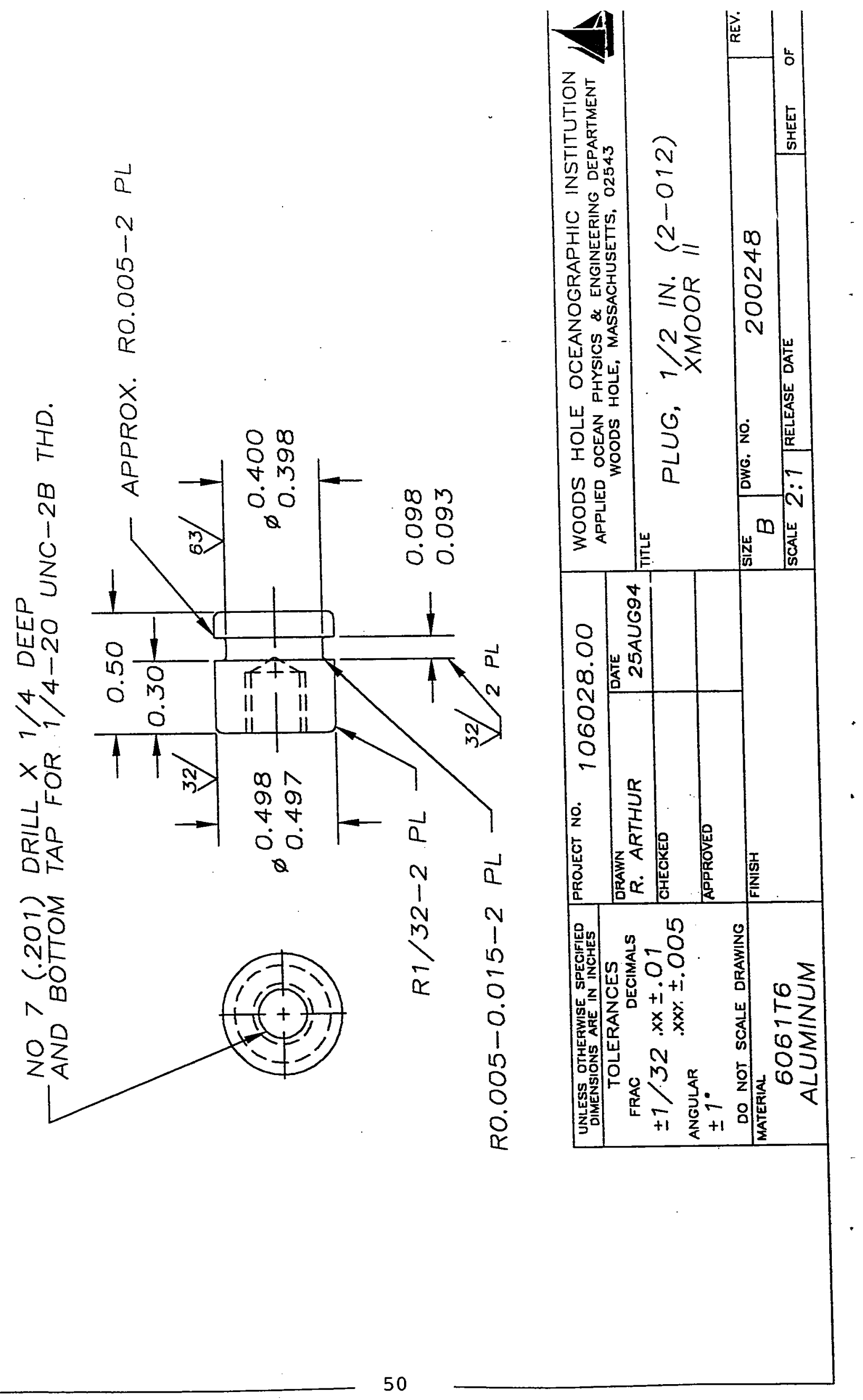


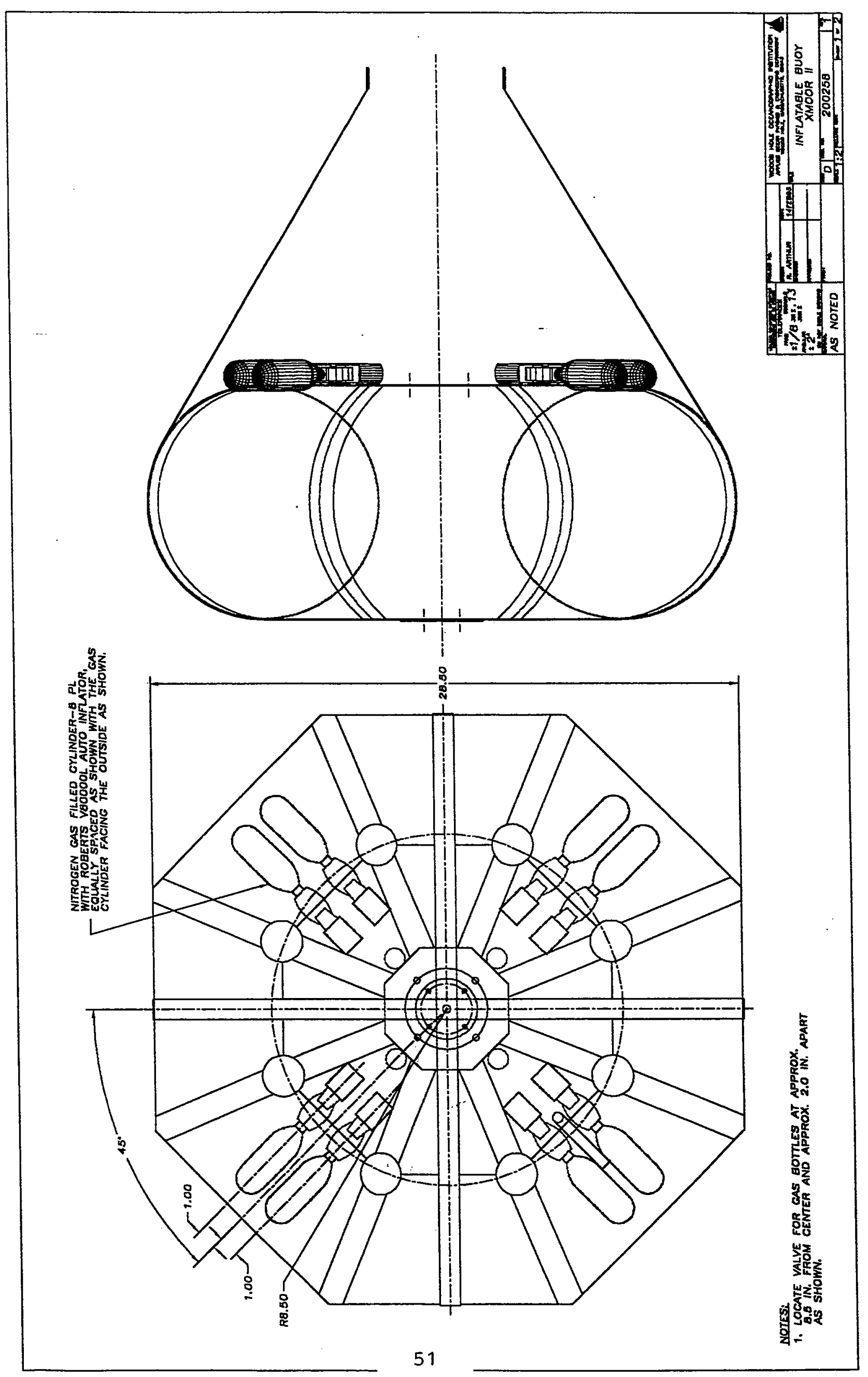




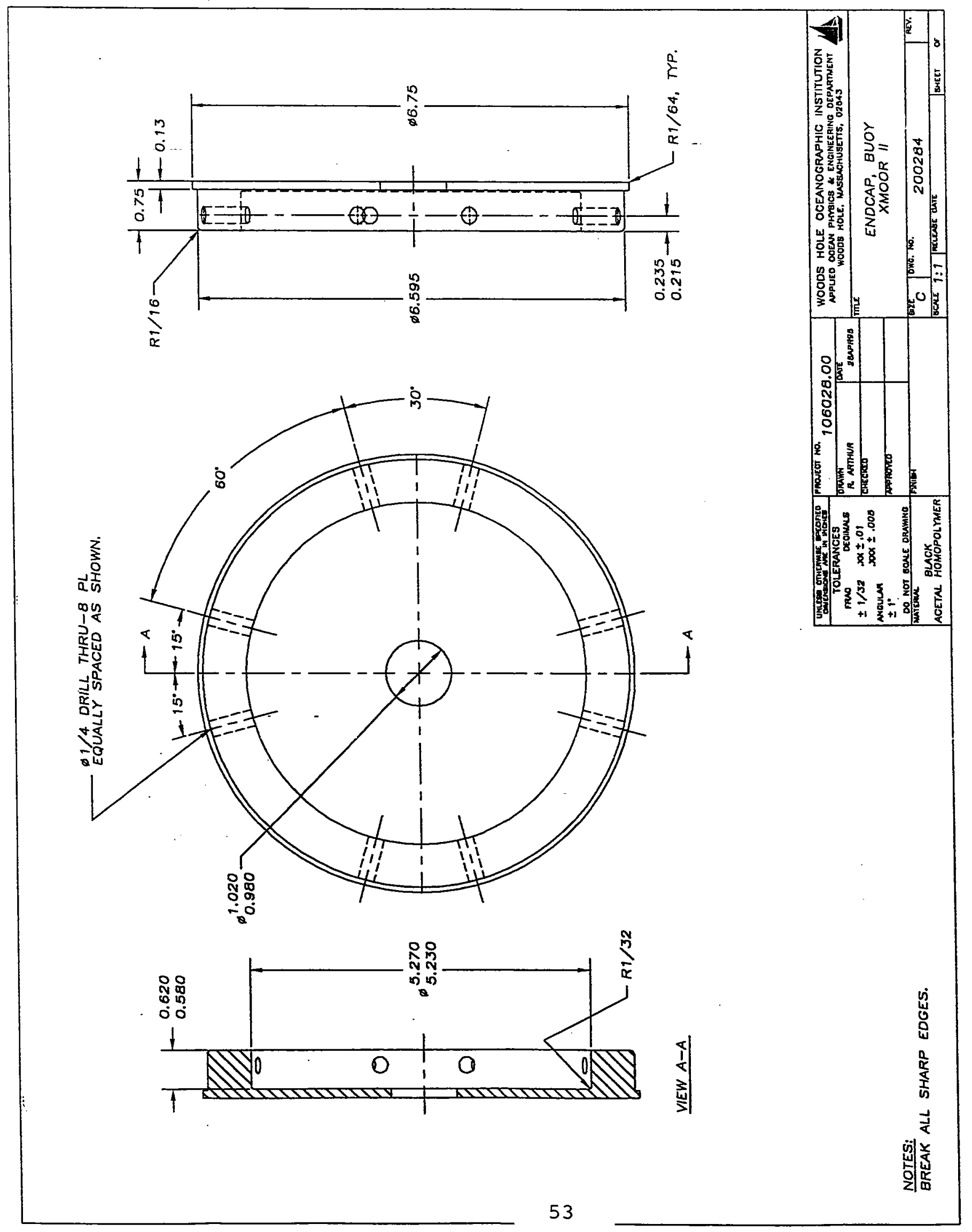




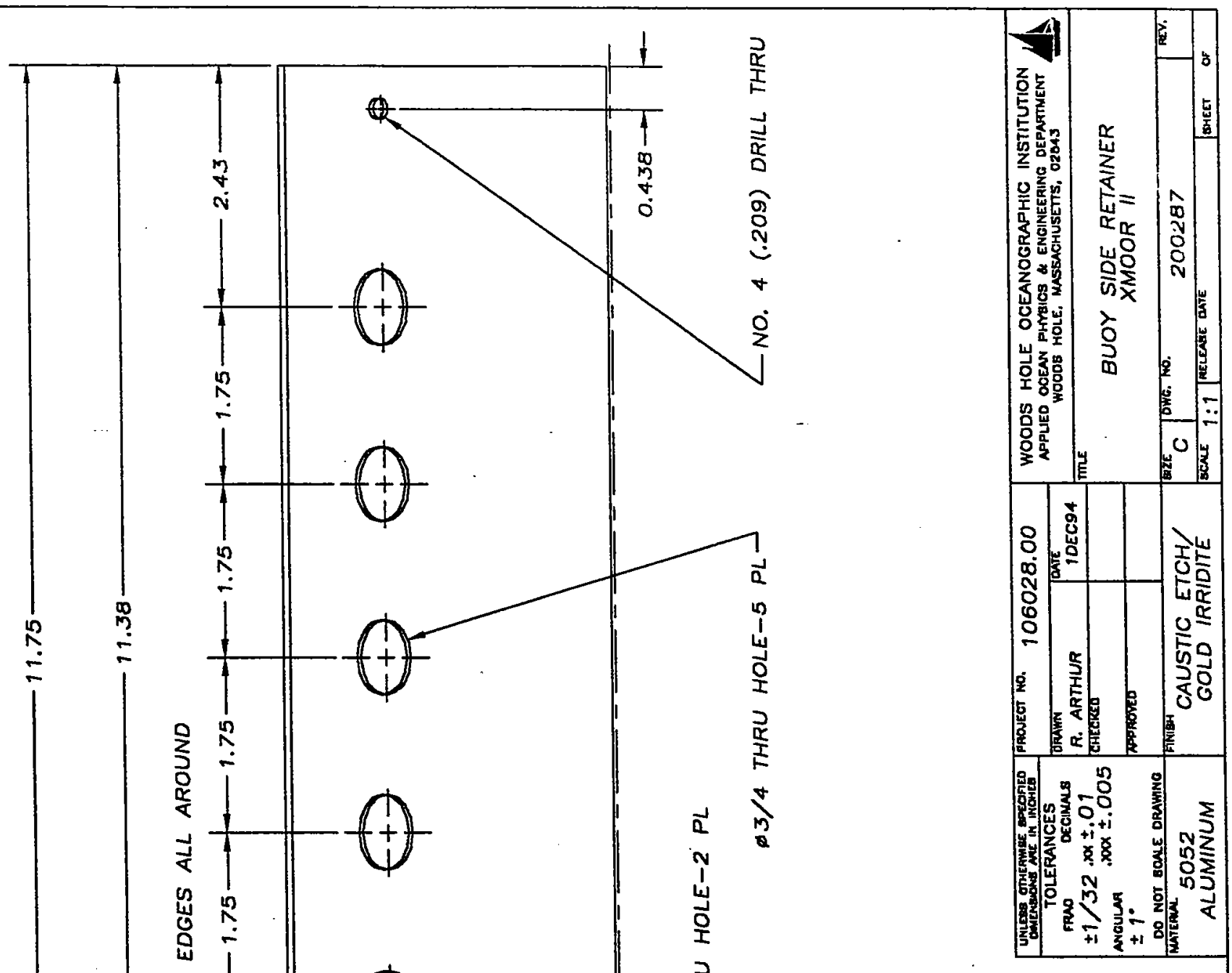




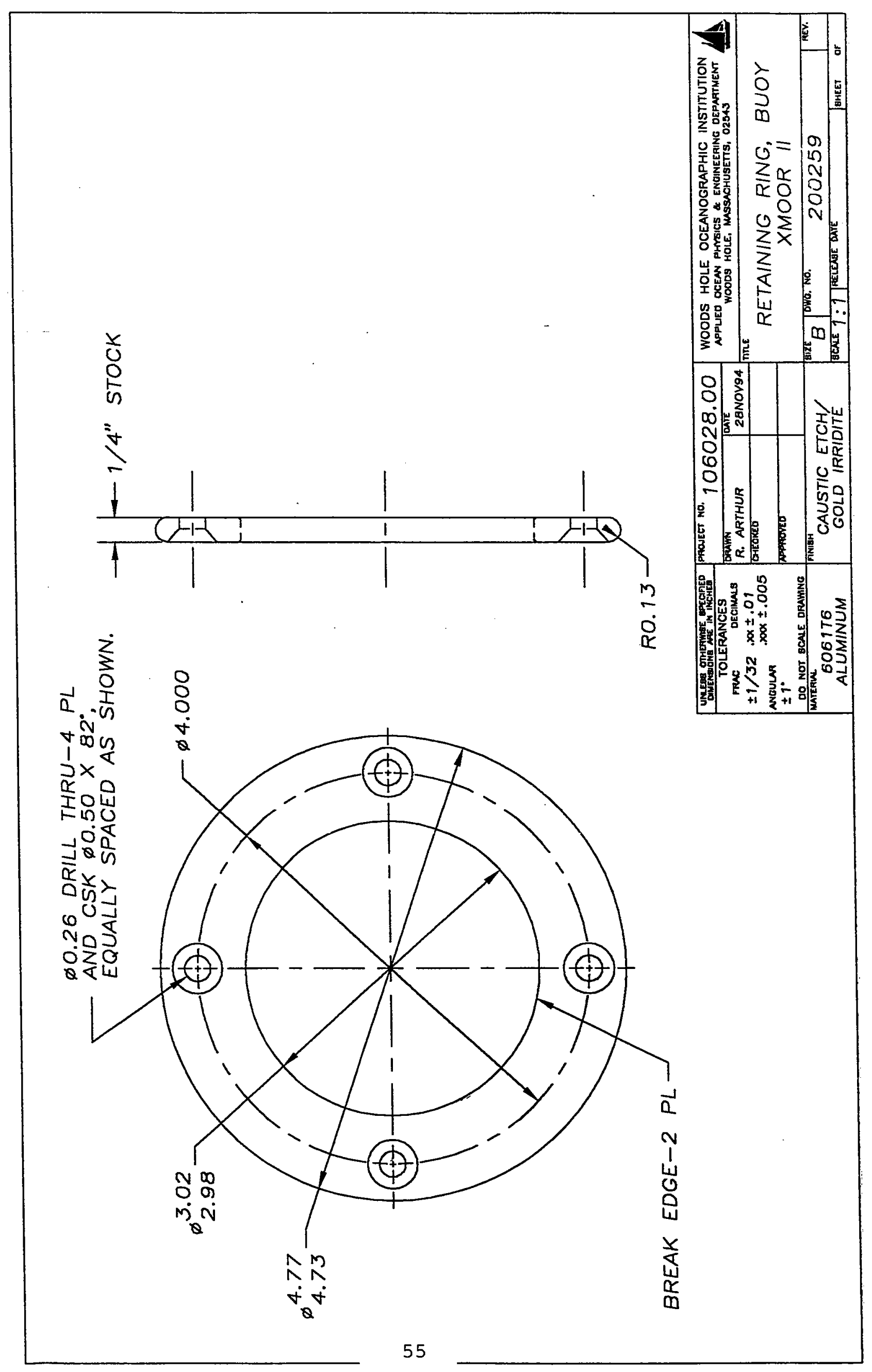




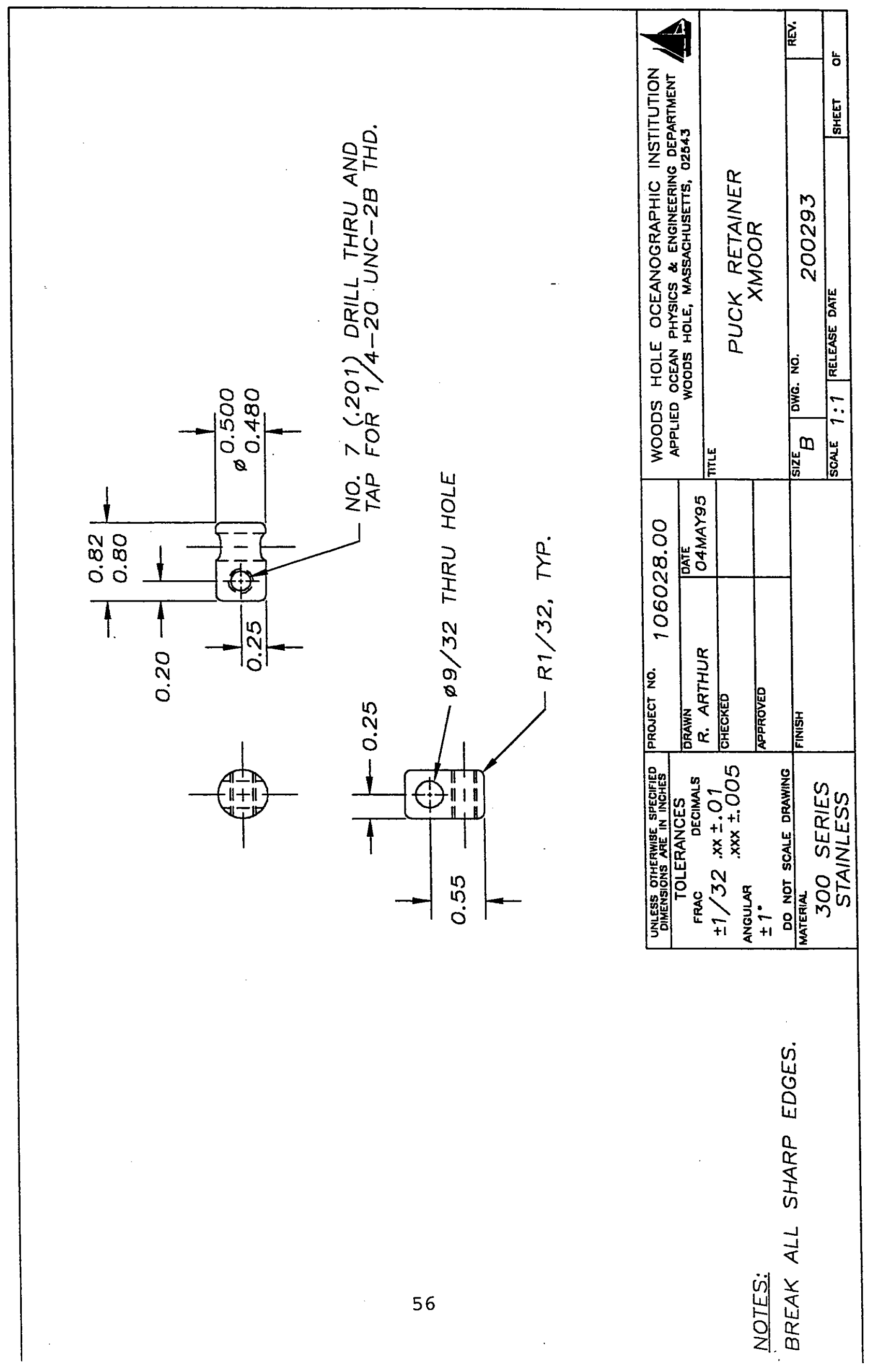



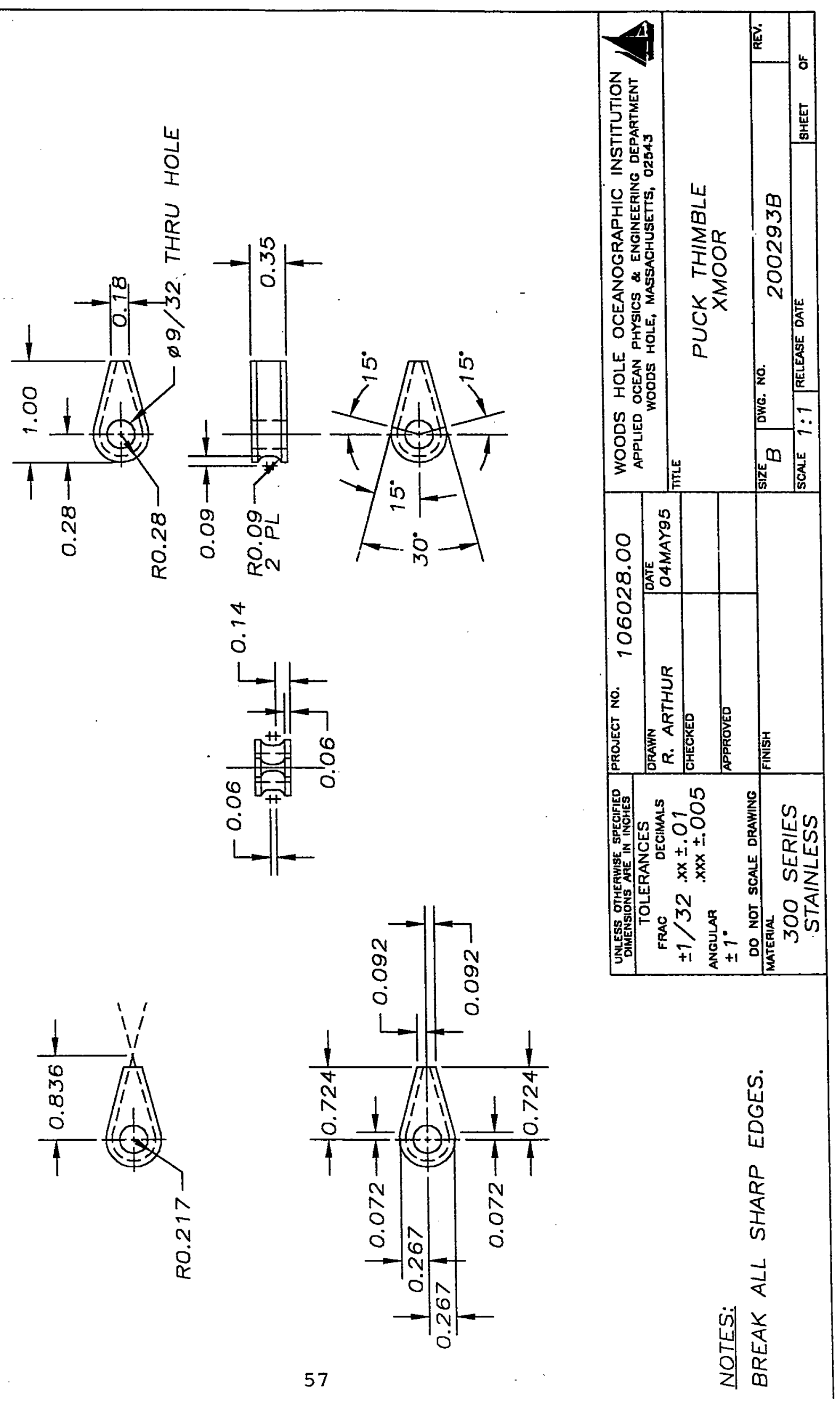

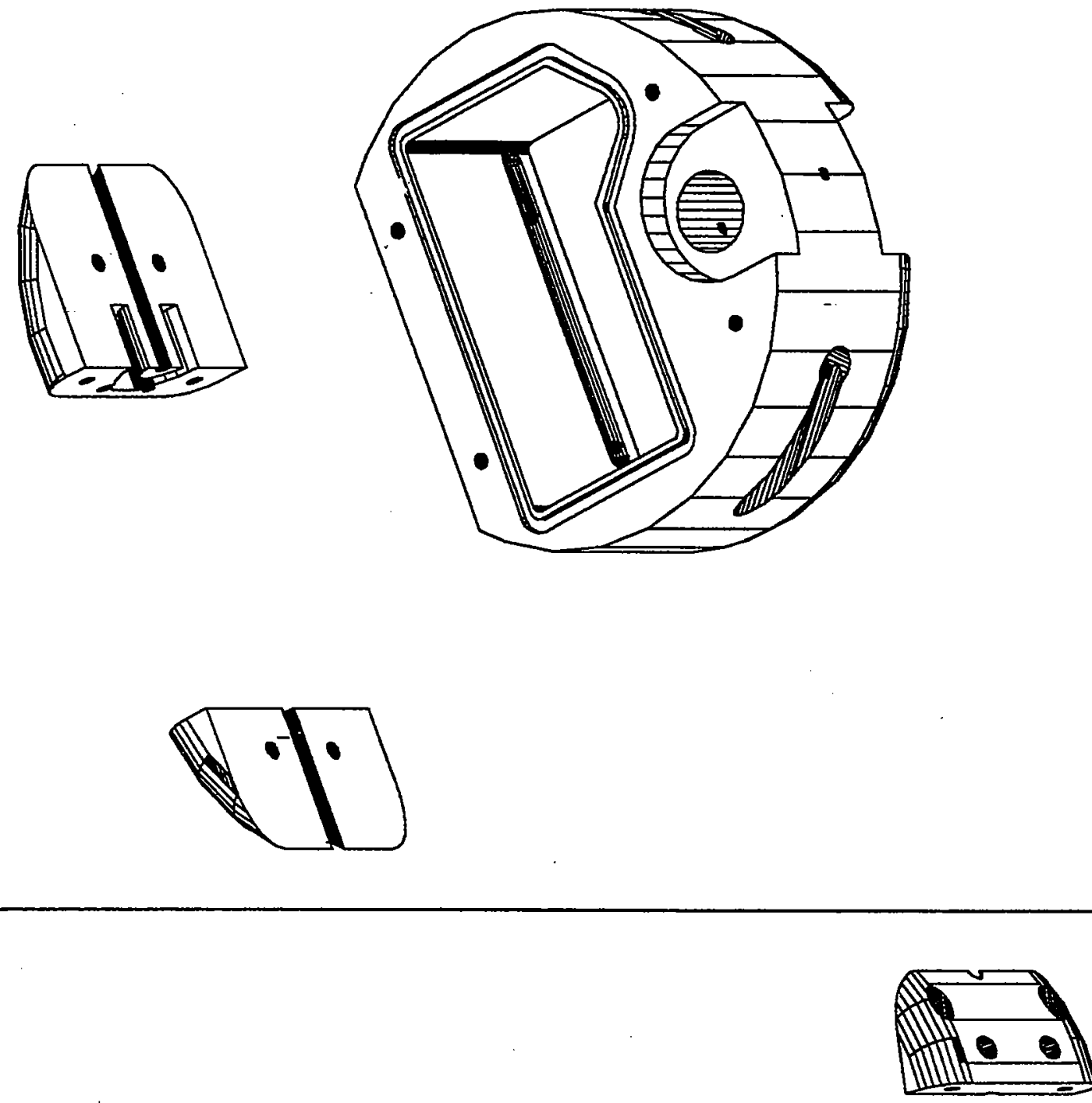

0
0
-7
0
5
0
-1
4
0
0
0
0
0
-7
+
0
0
-1
0
0
0
0
4
0
0
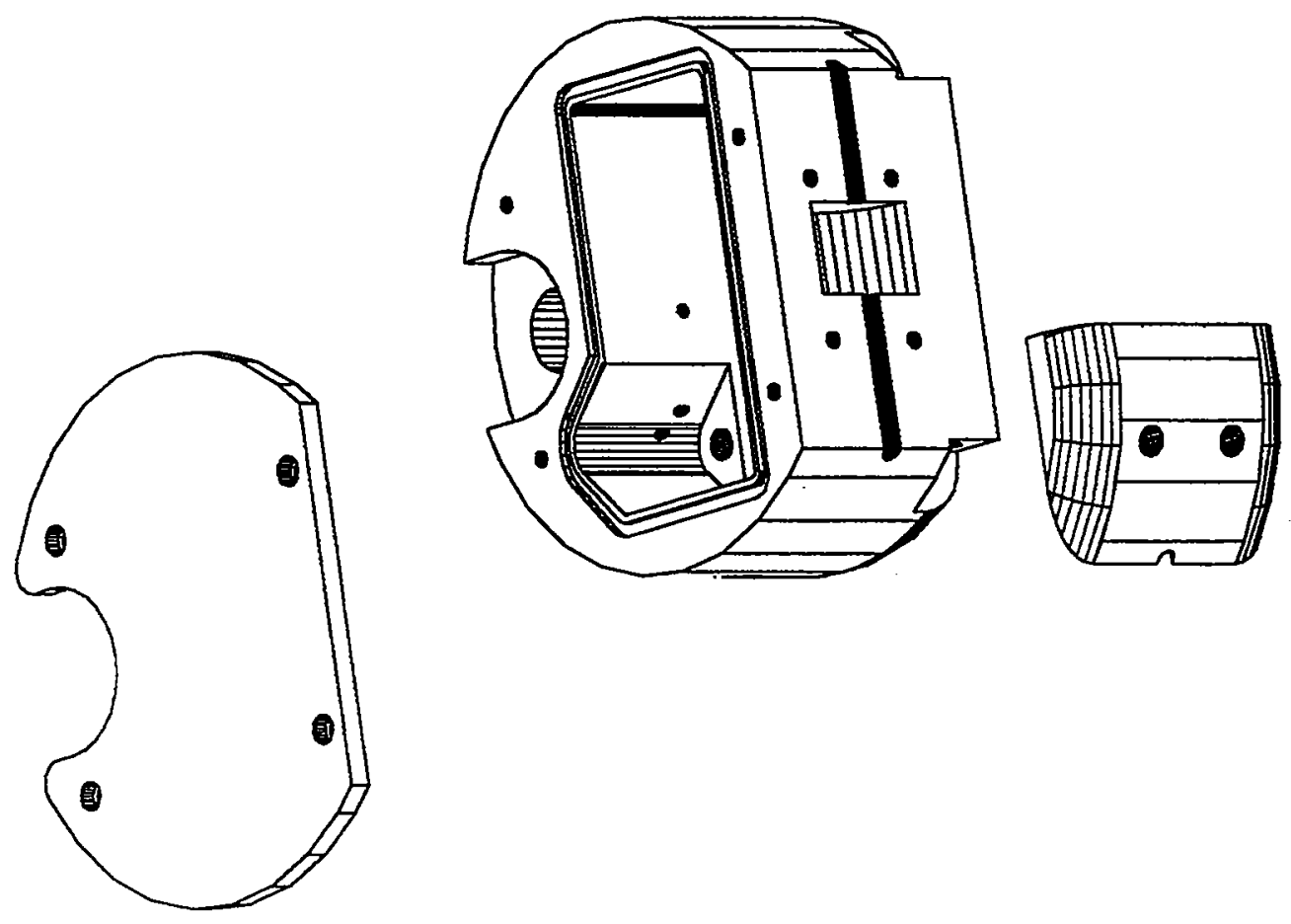


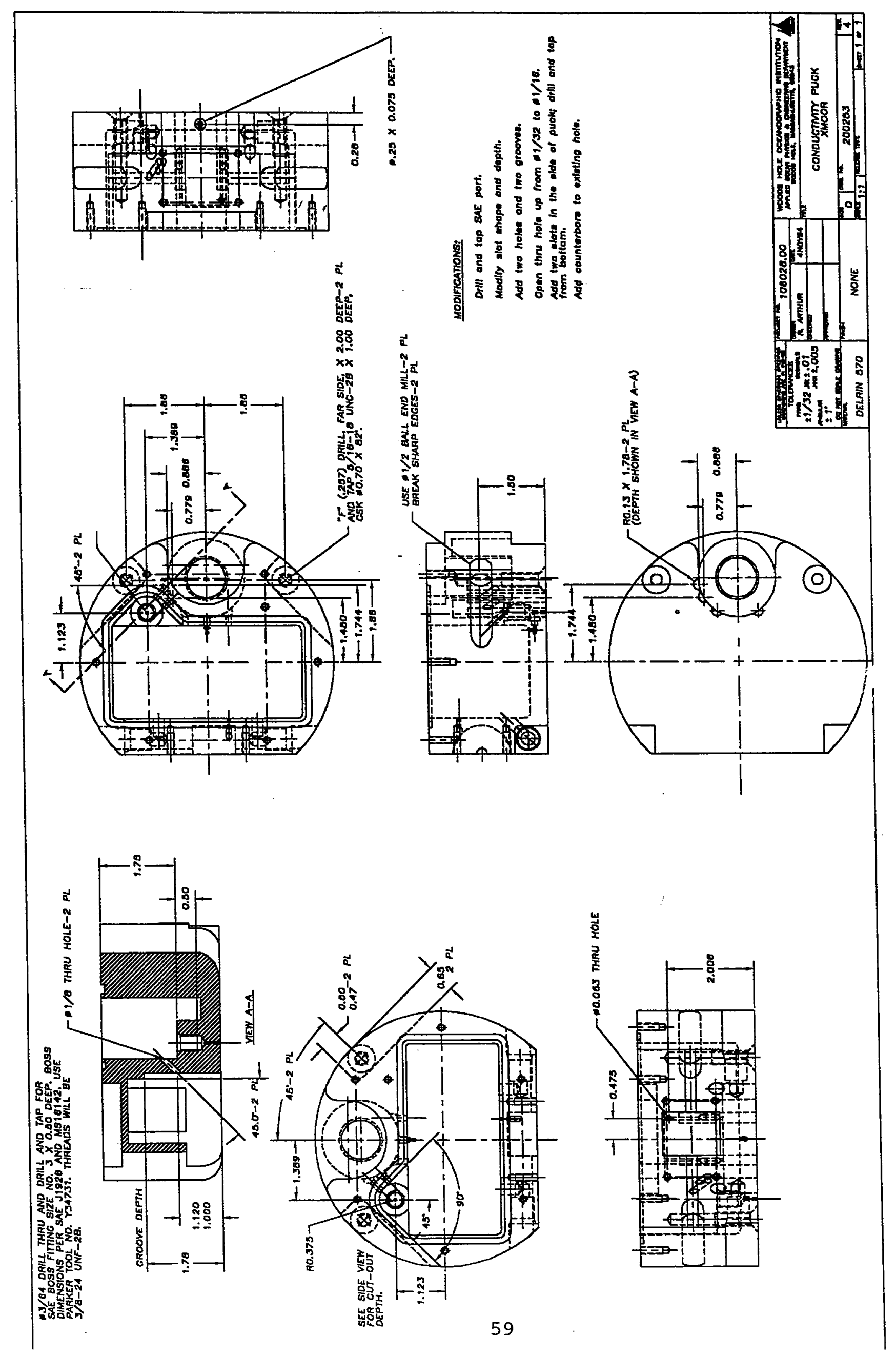




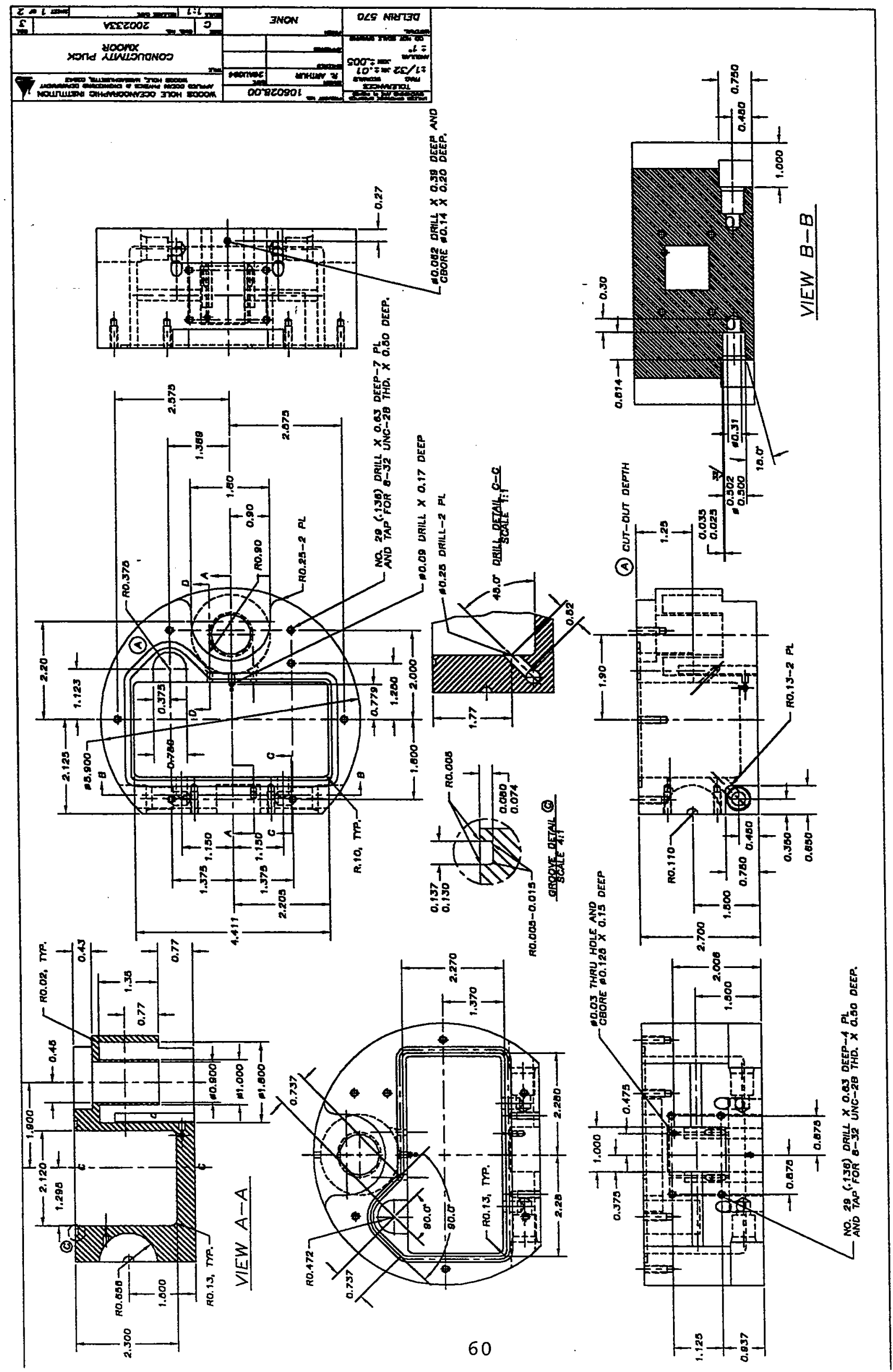




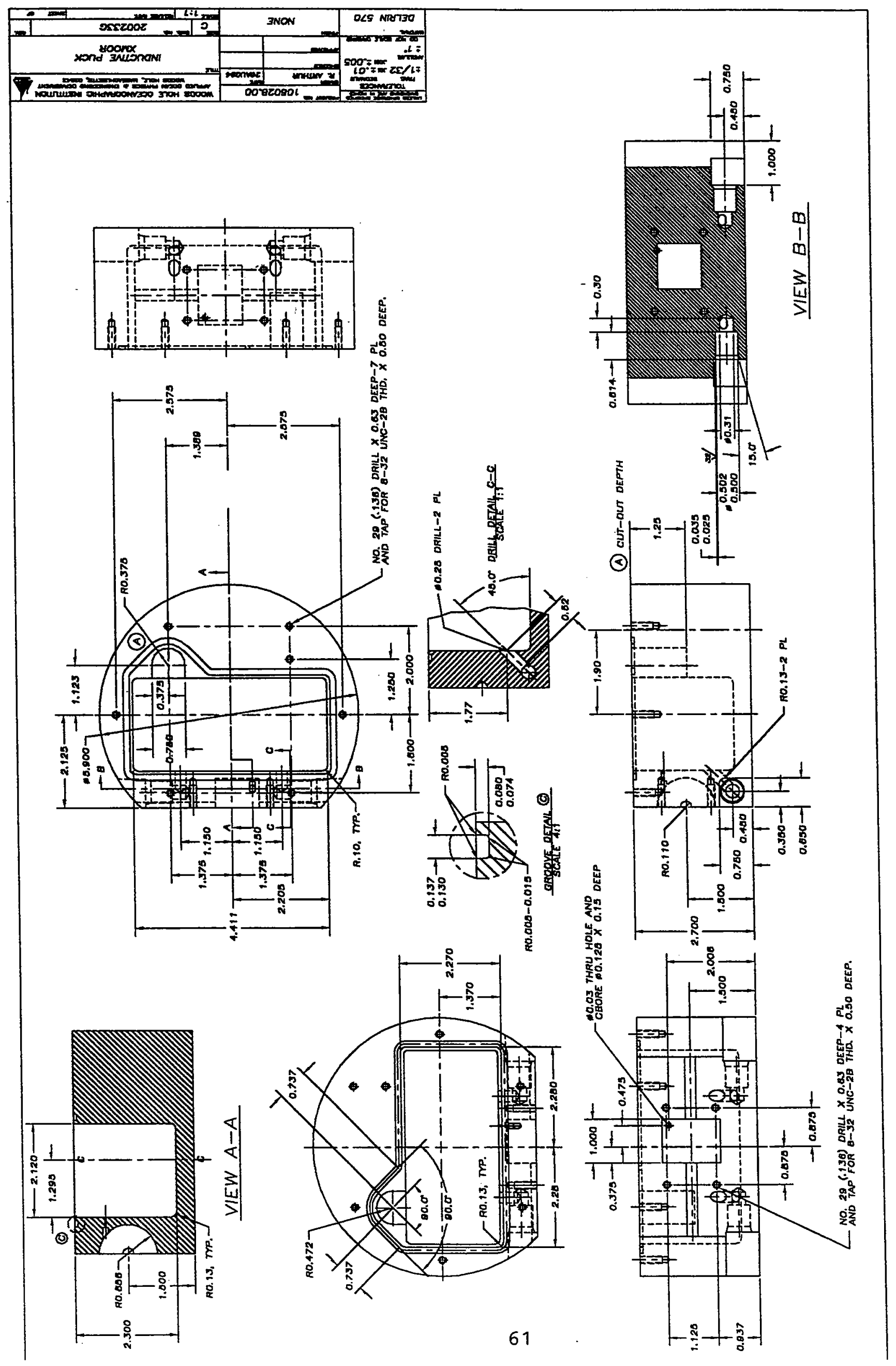




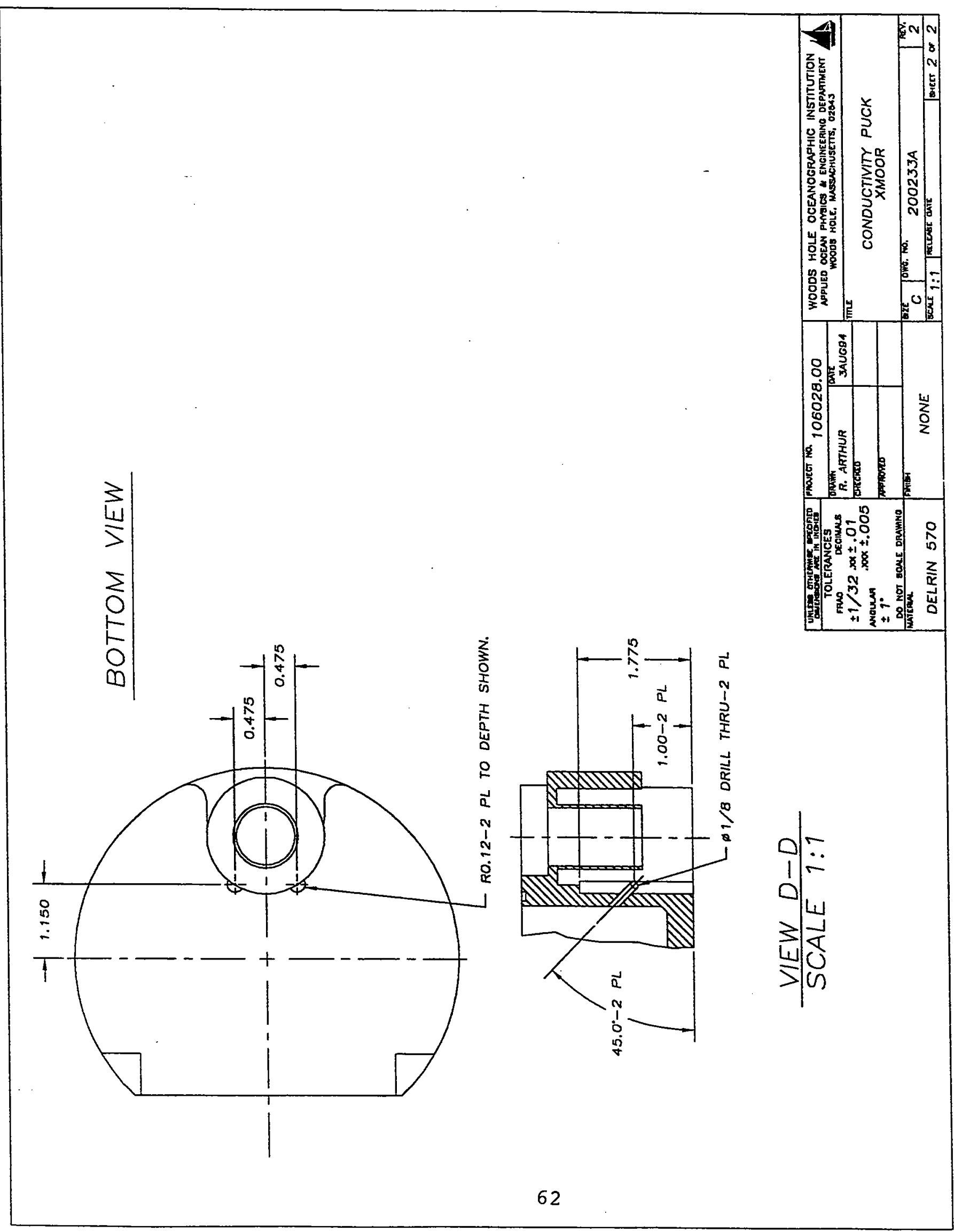




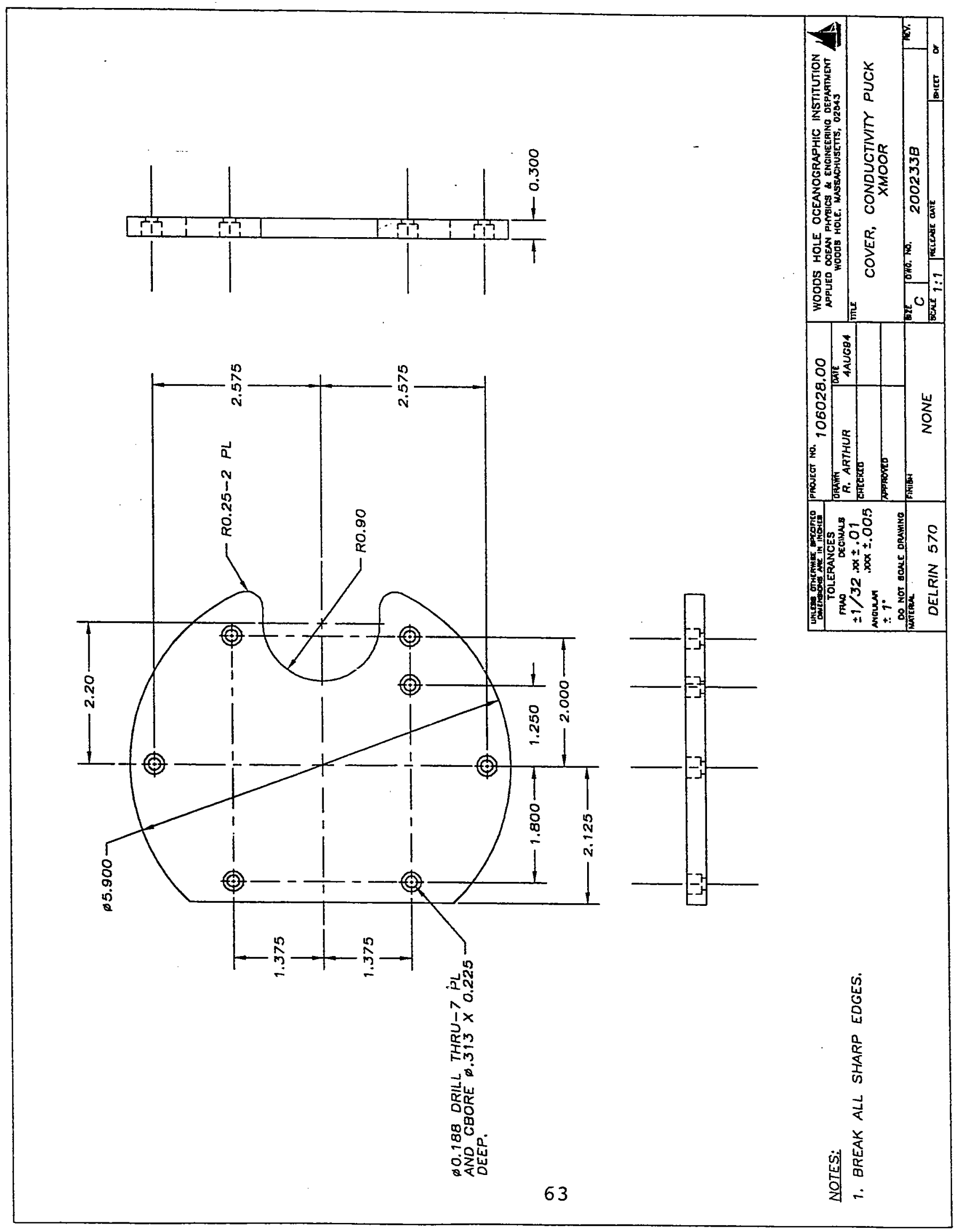




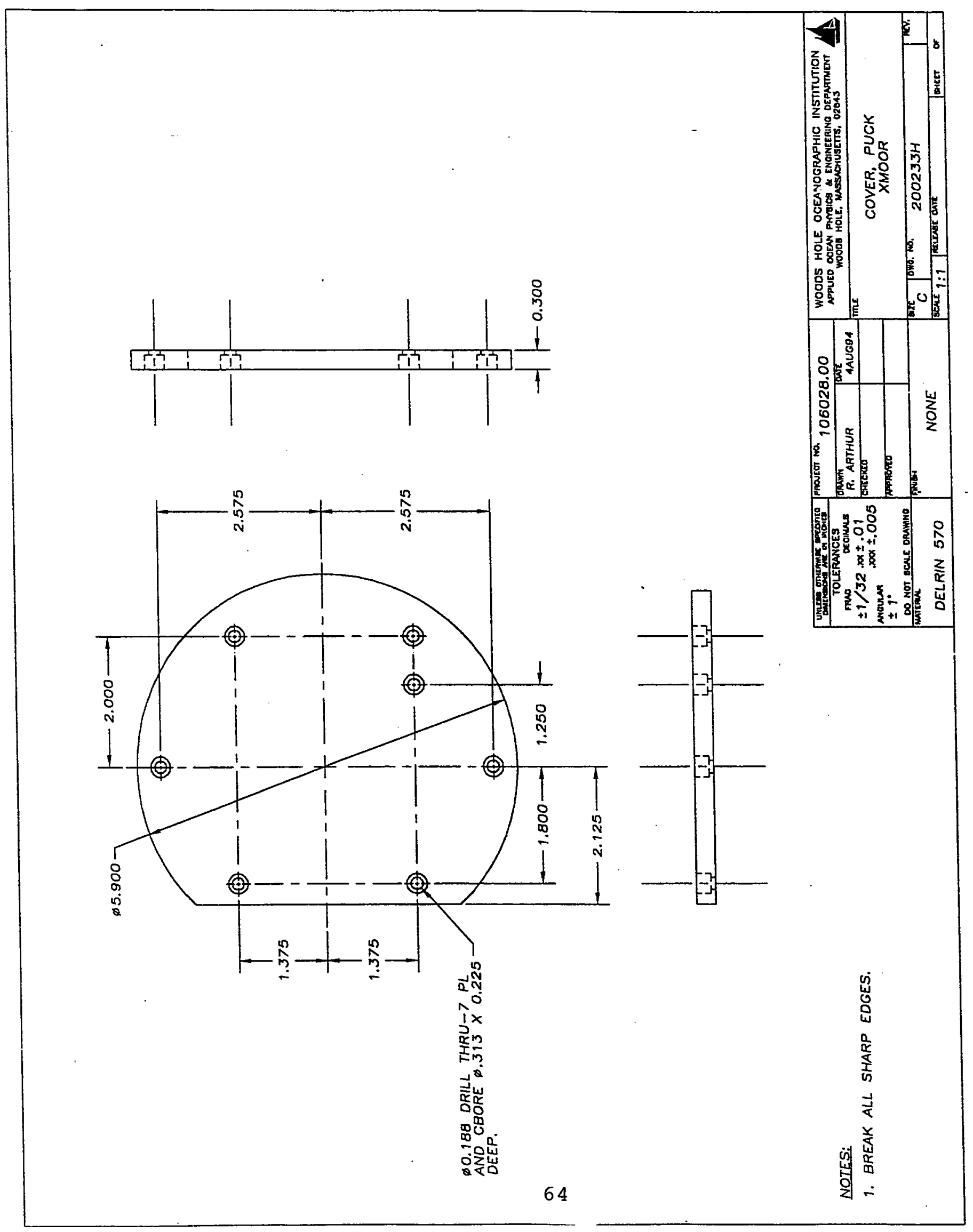




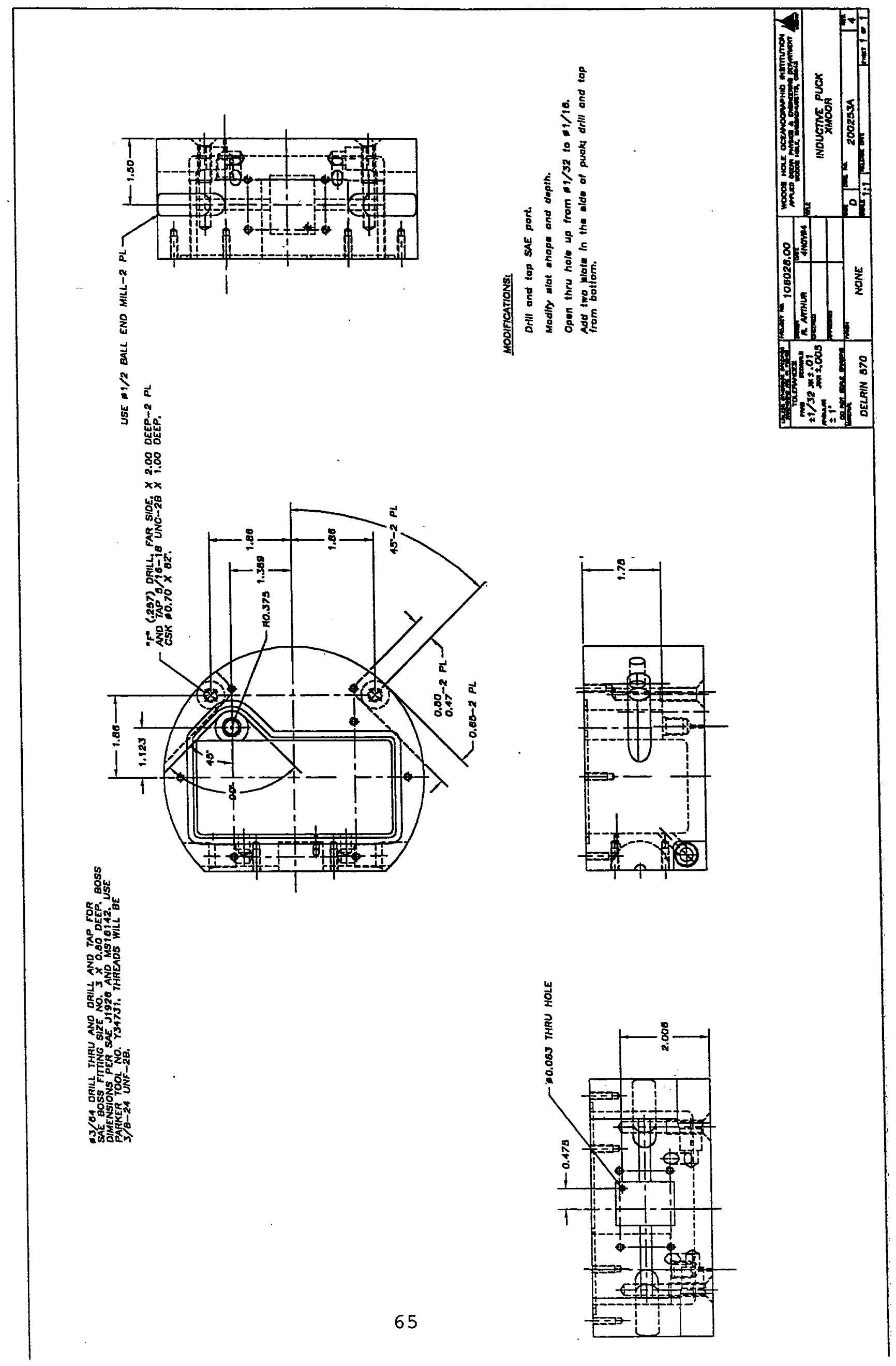




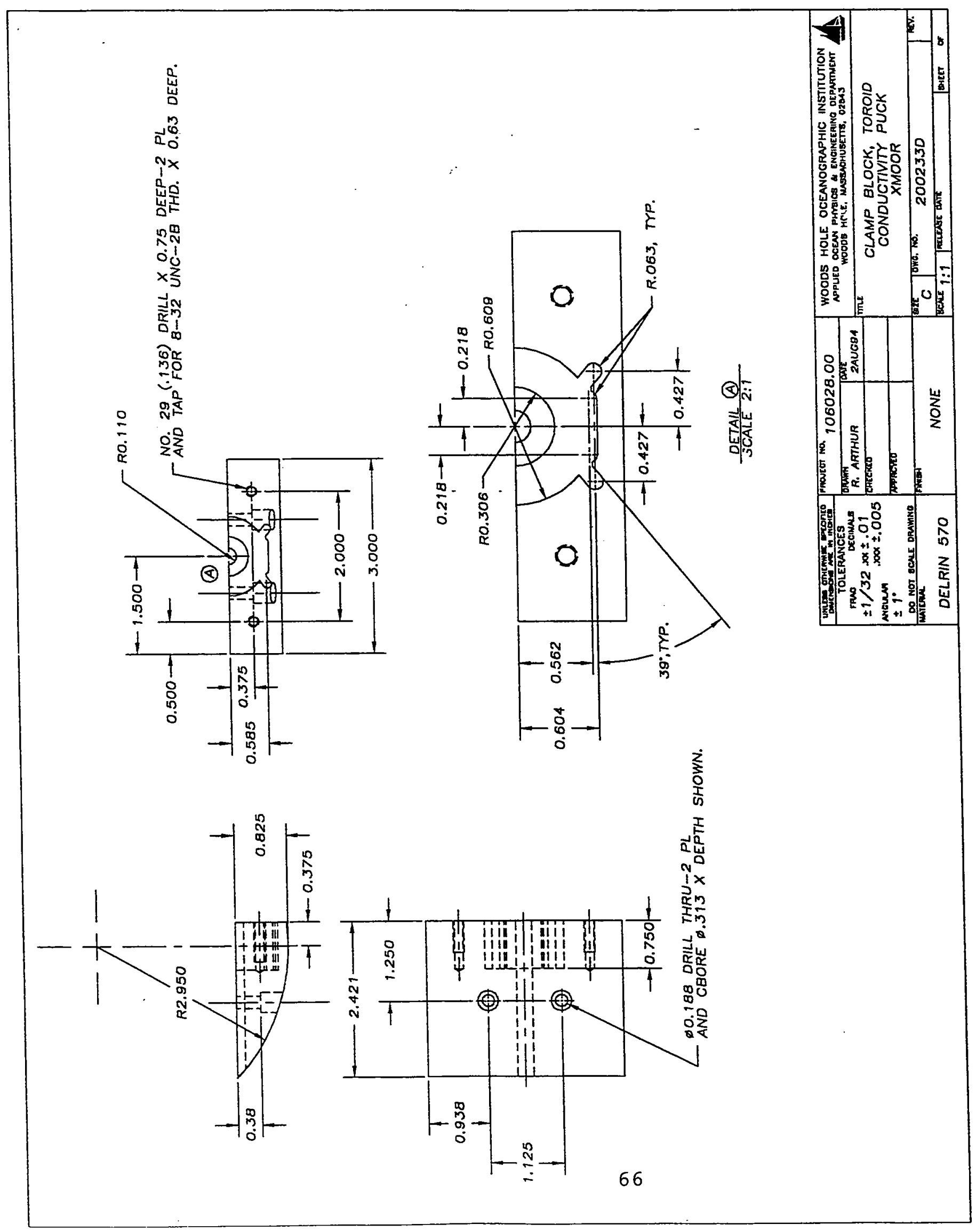




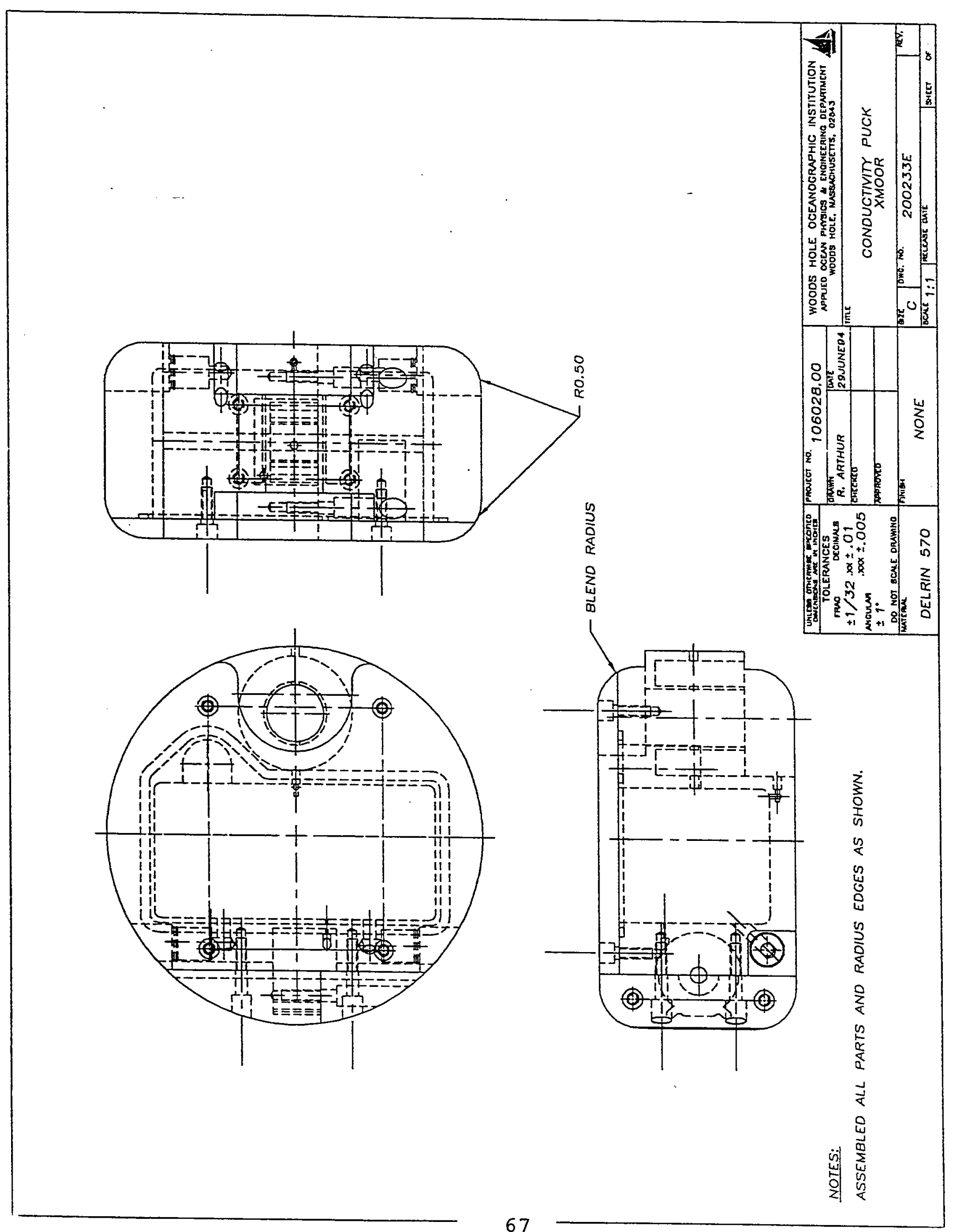




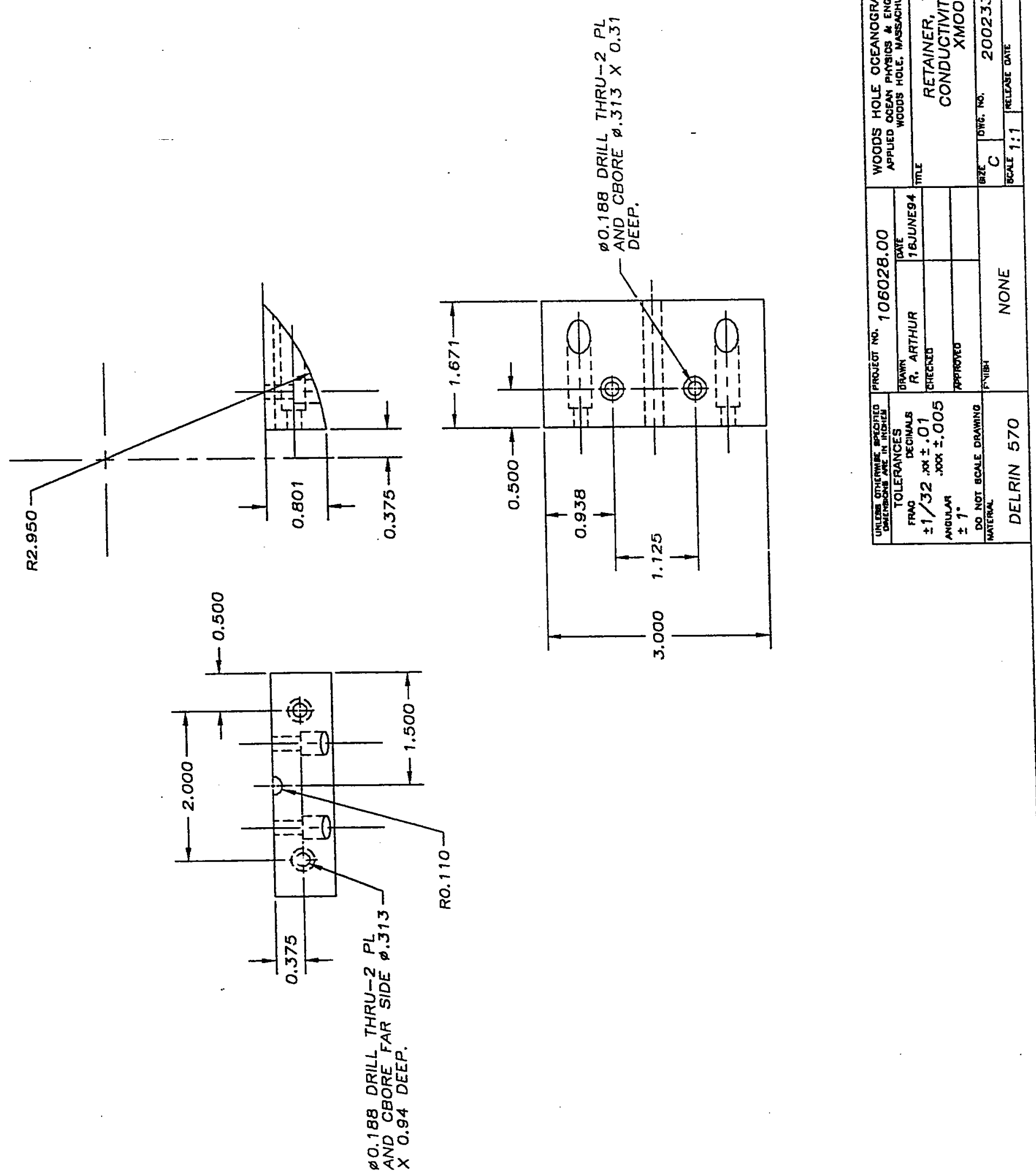




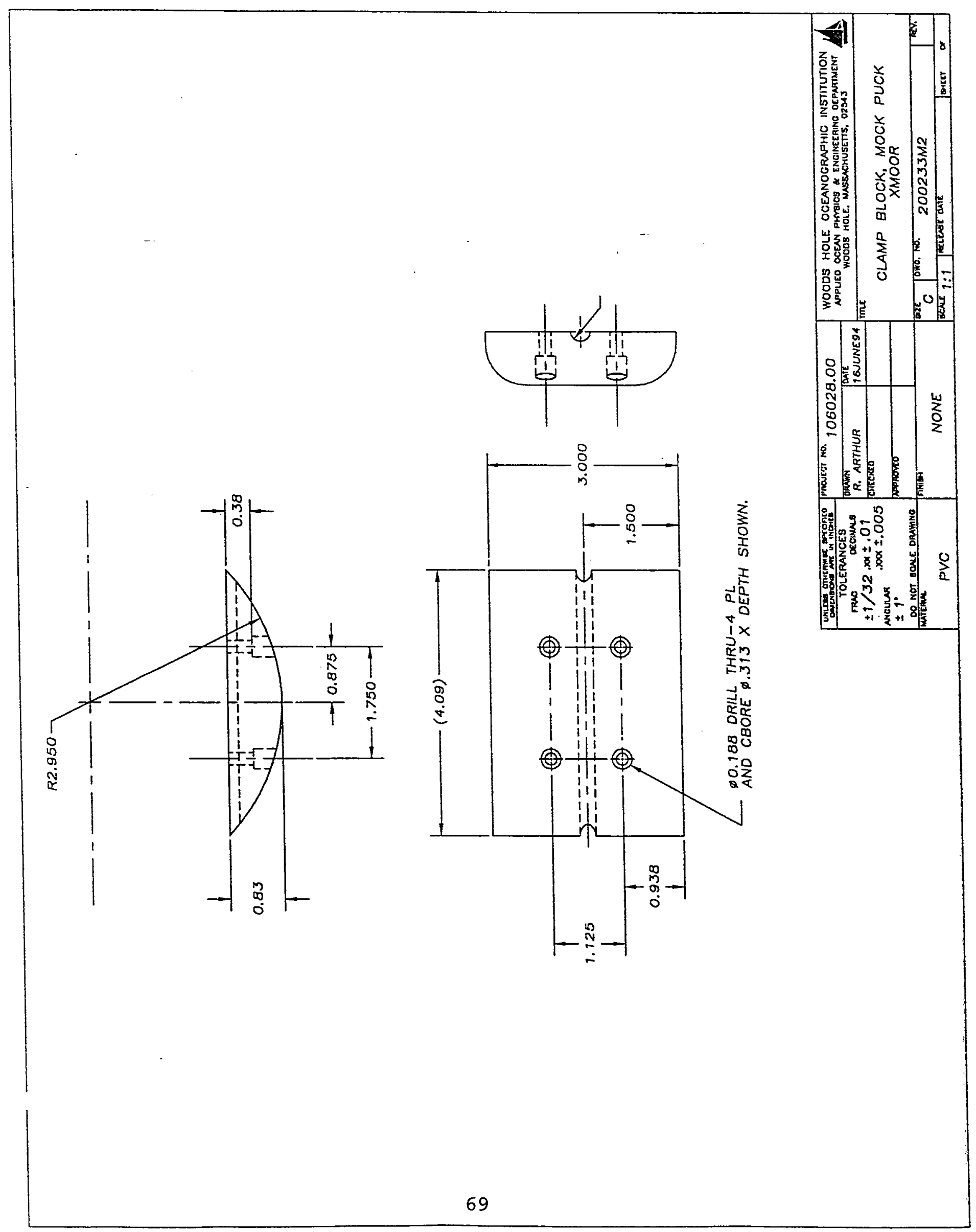




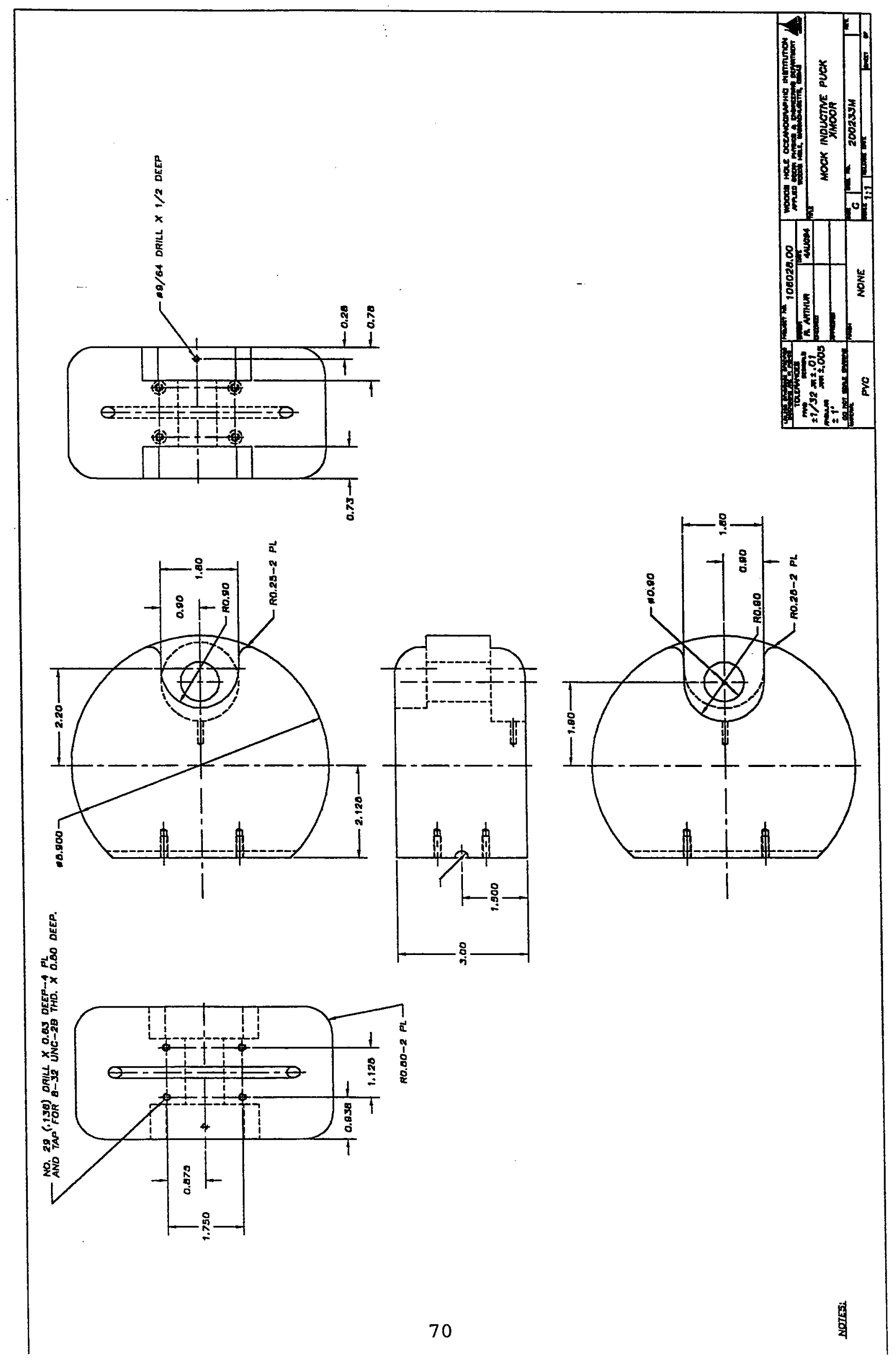




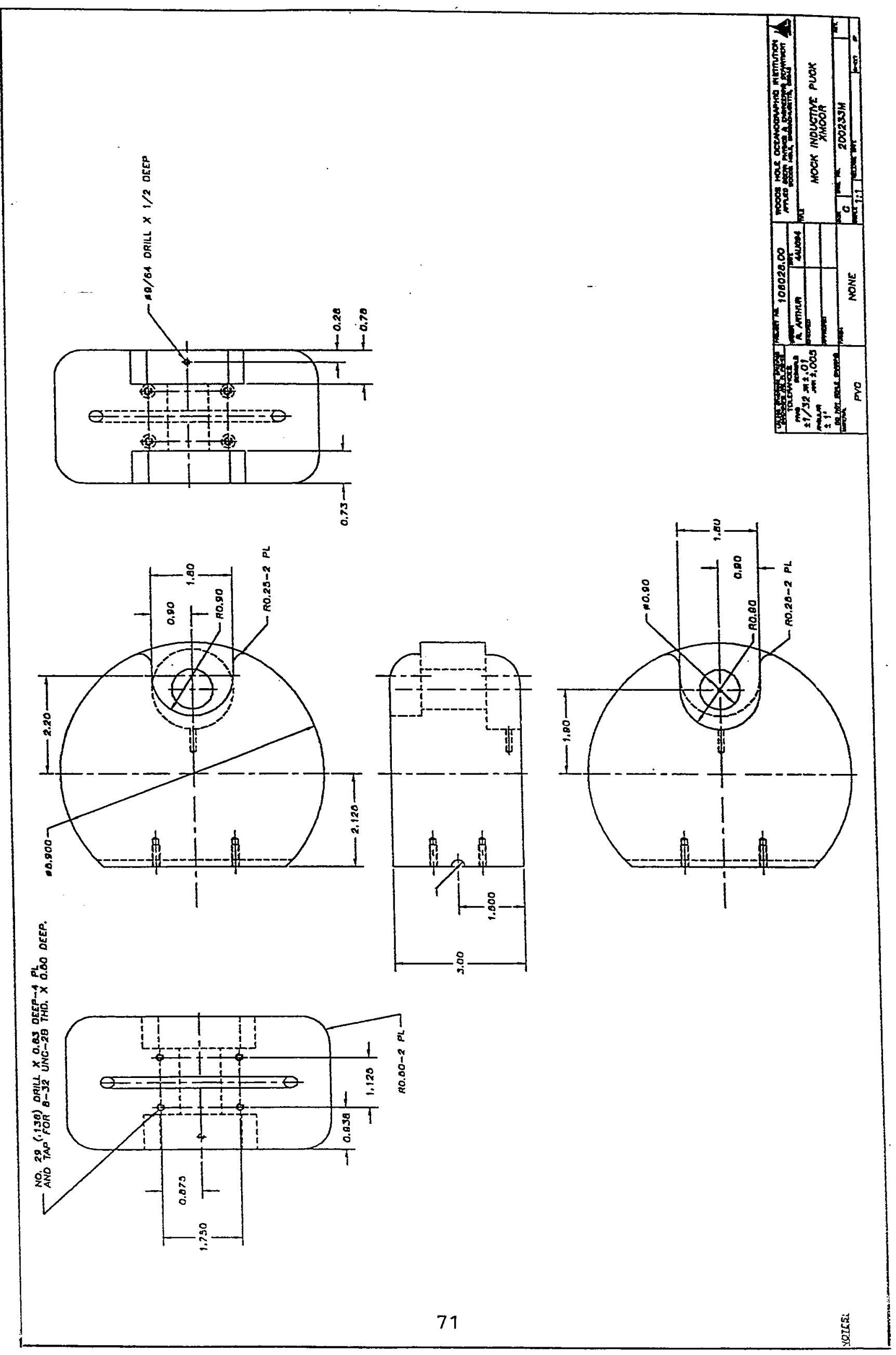




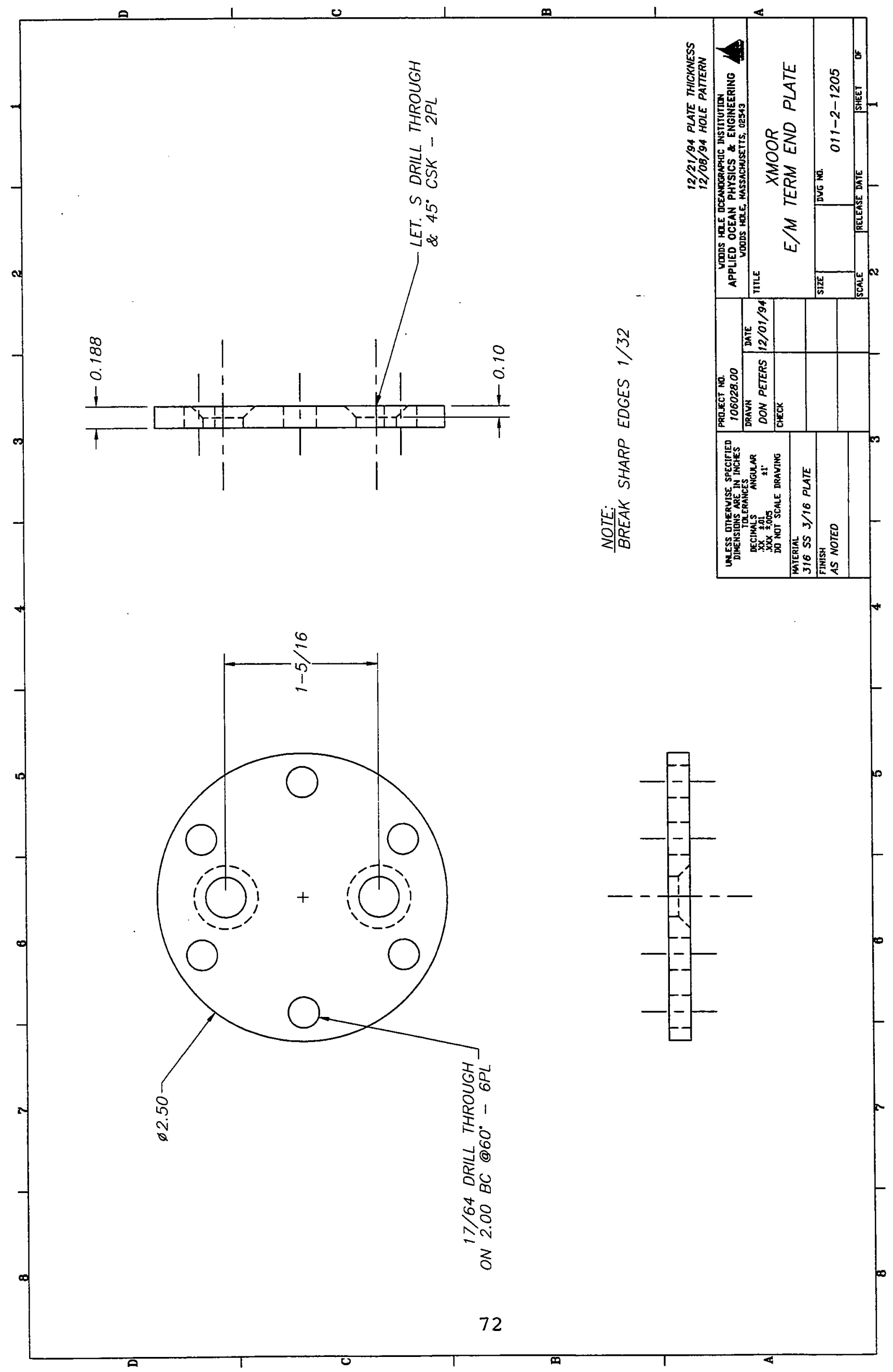




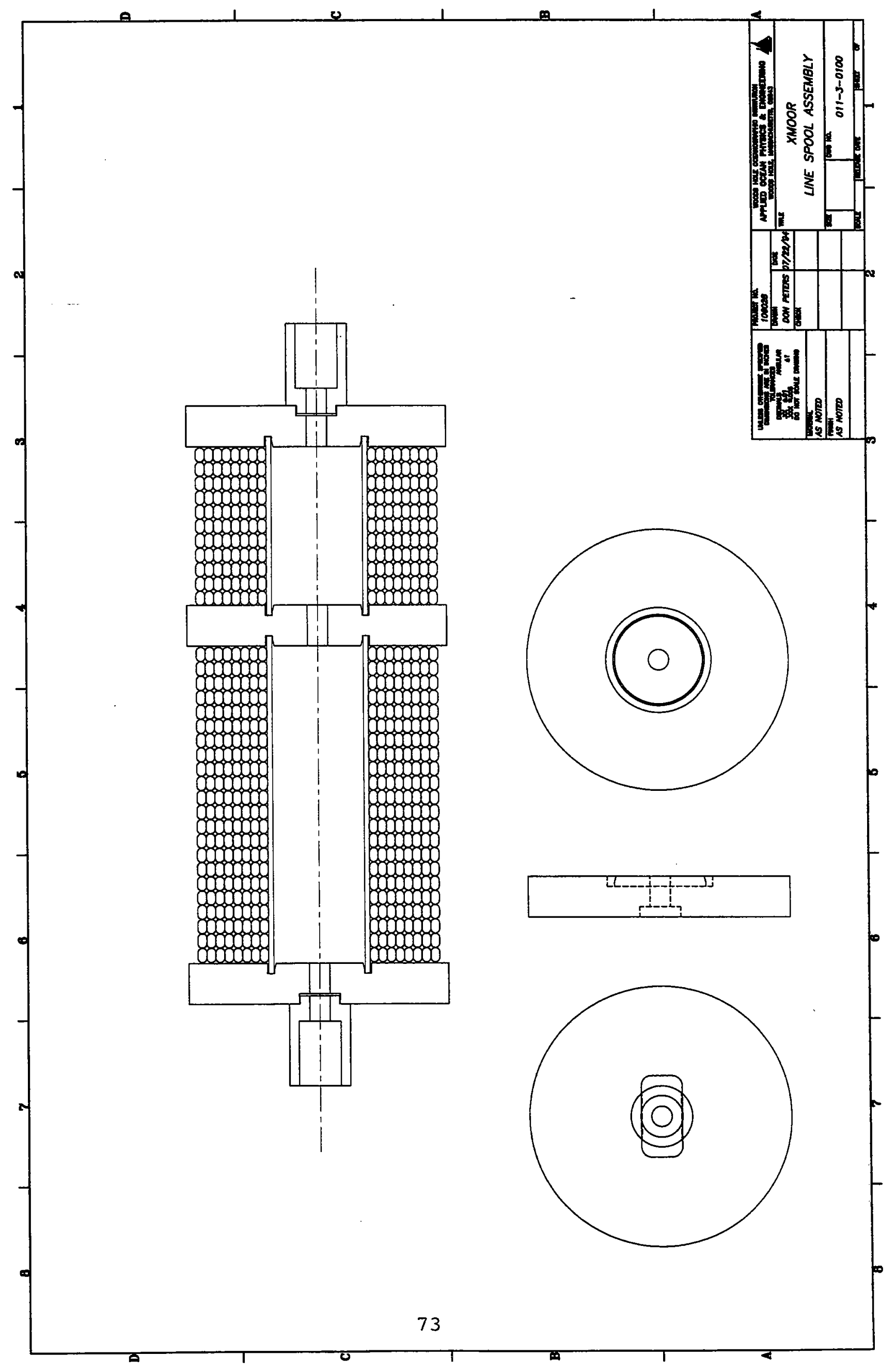




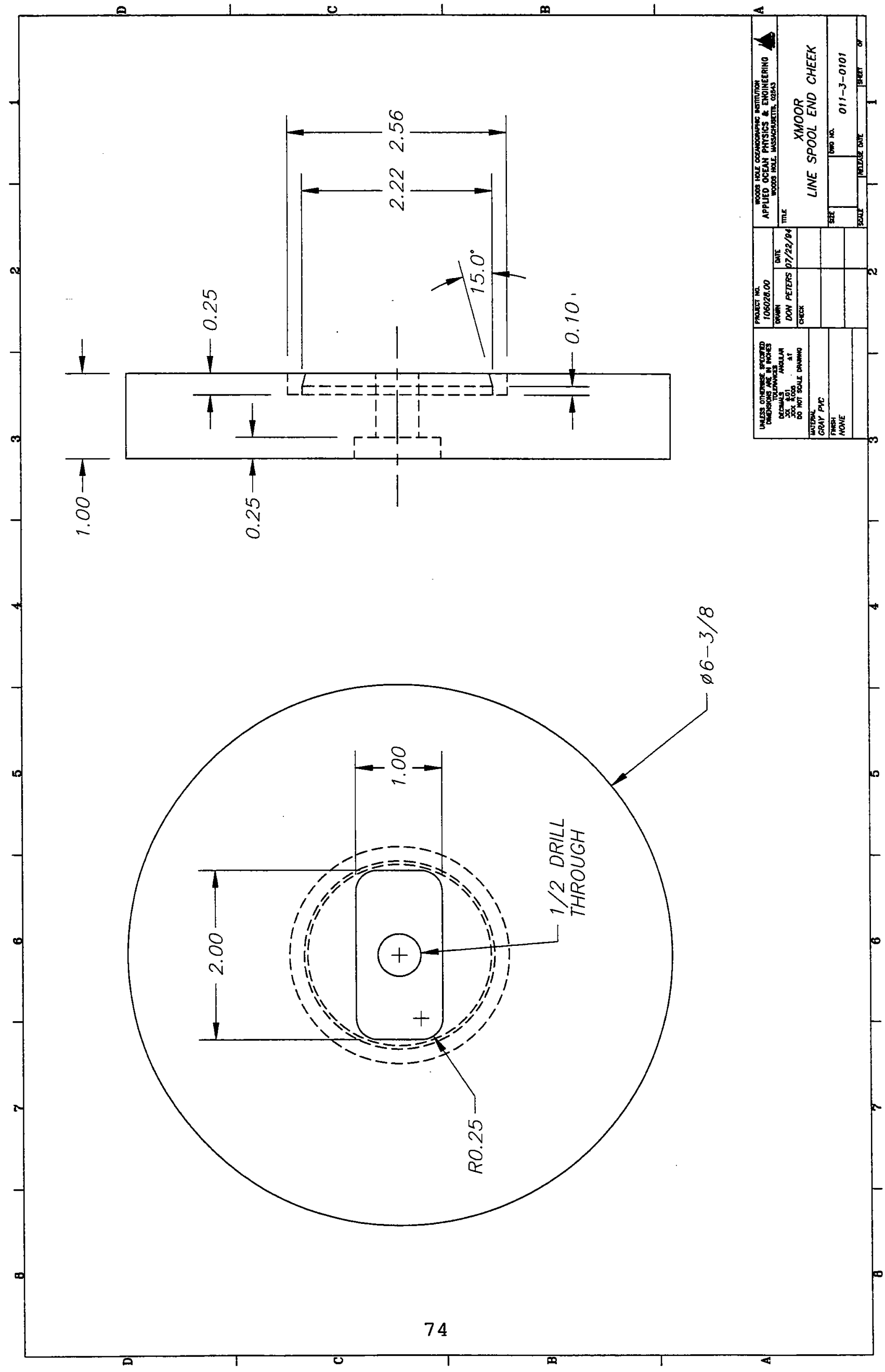




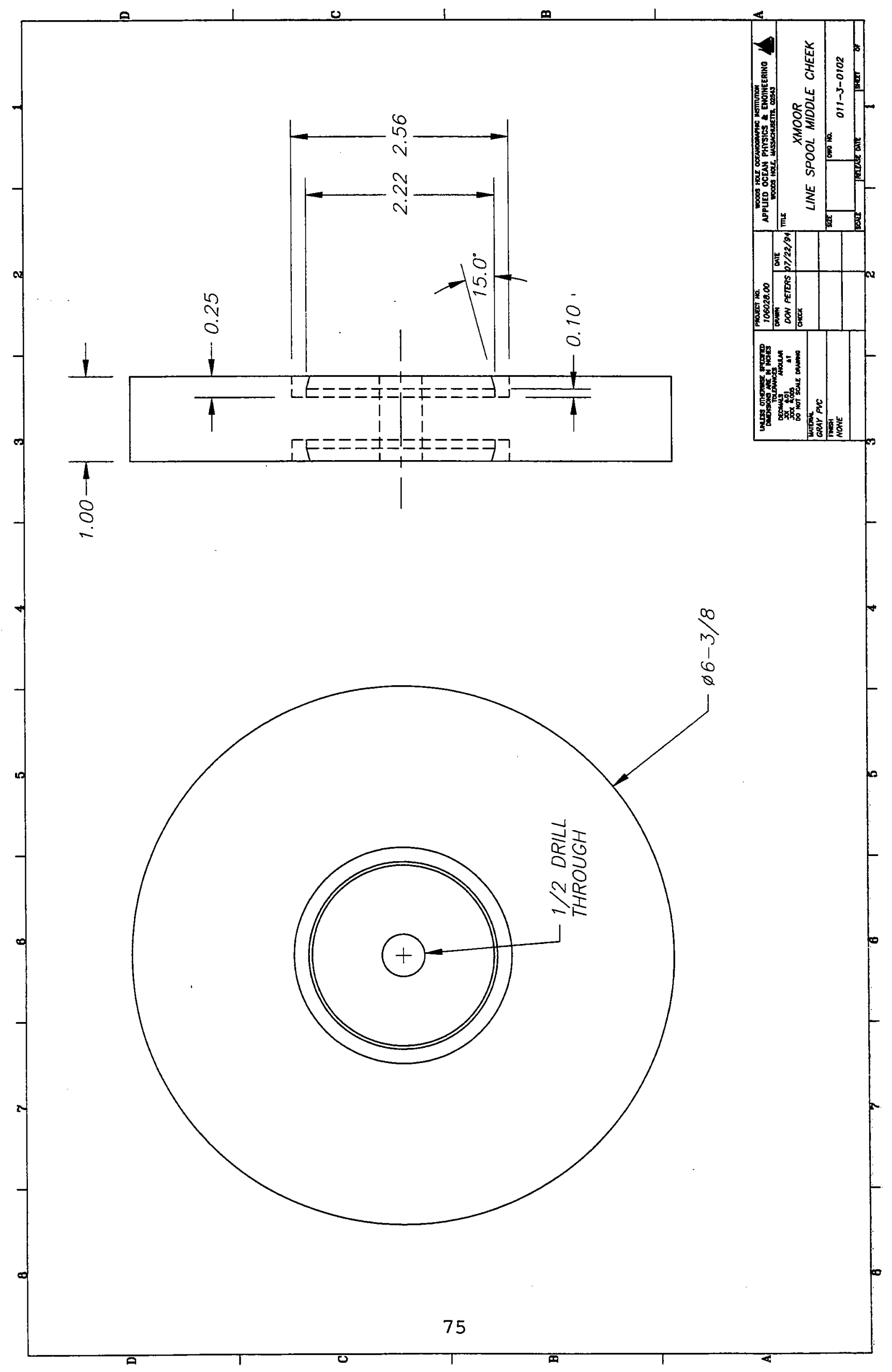




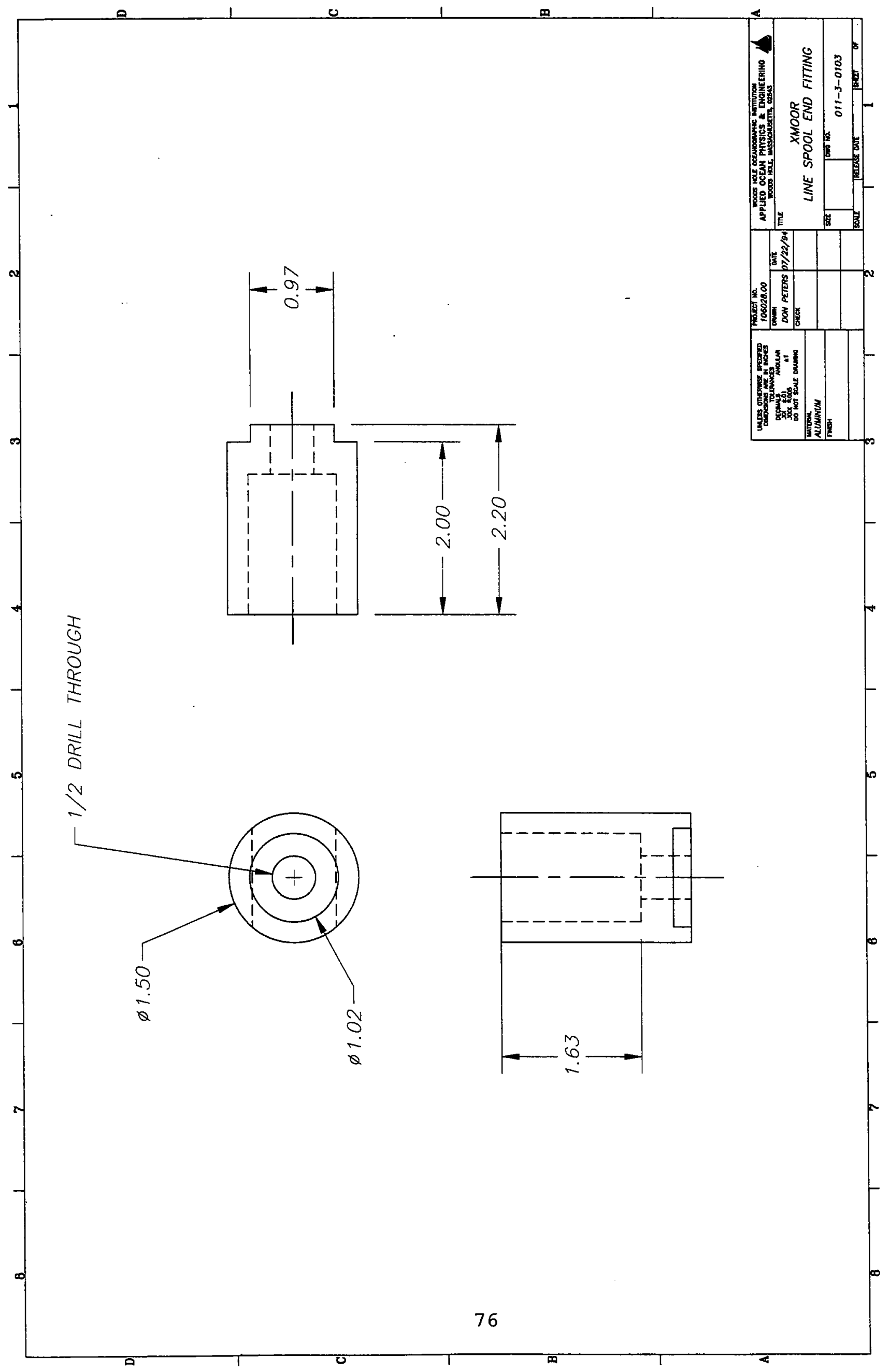




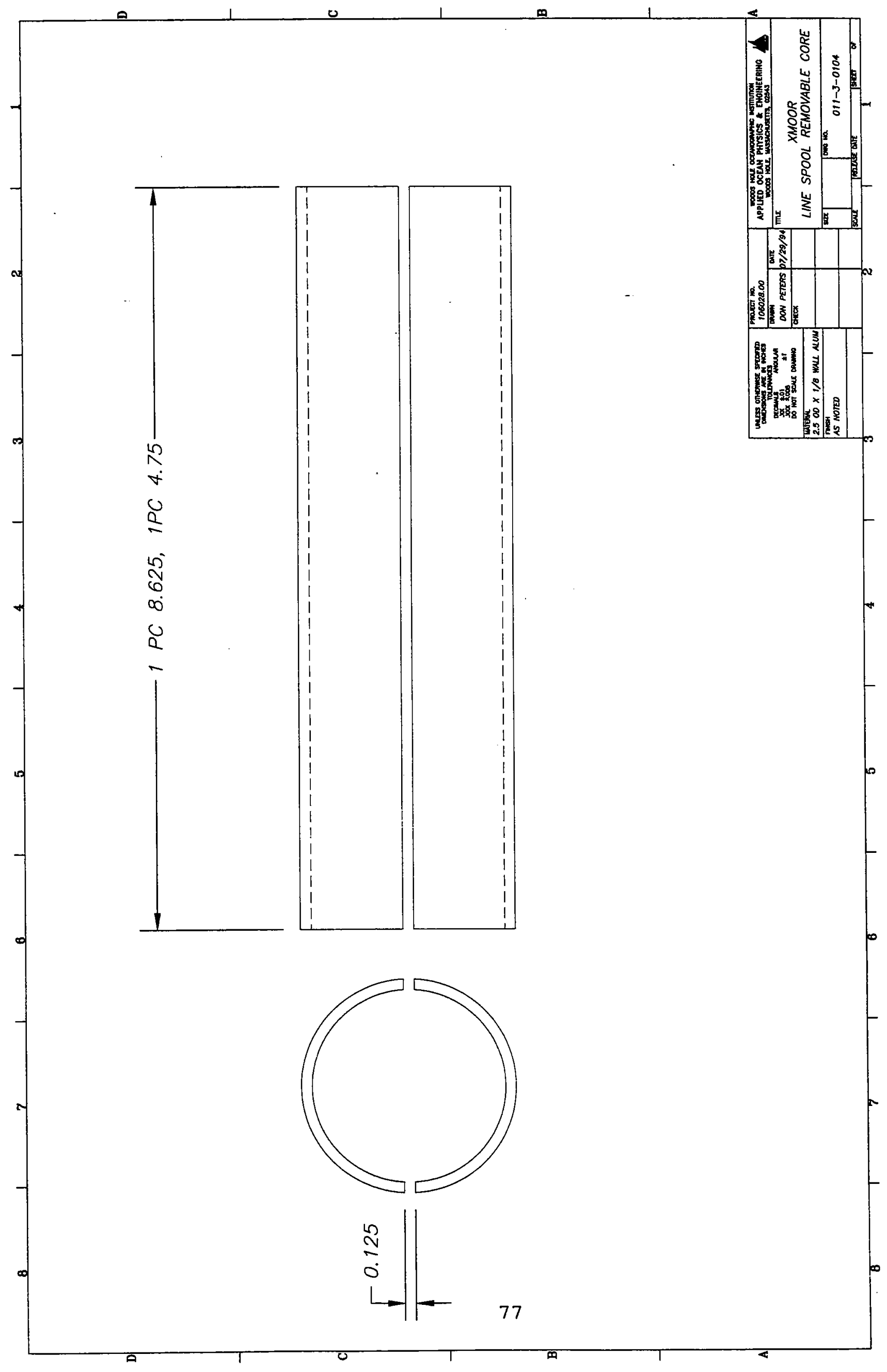



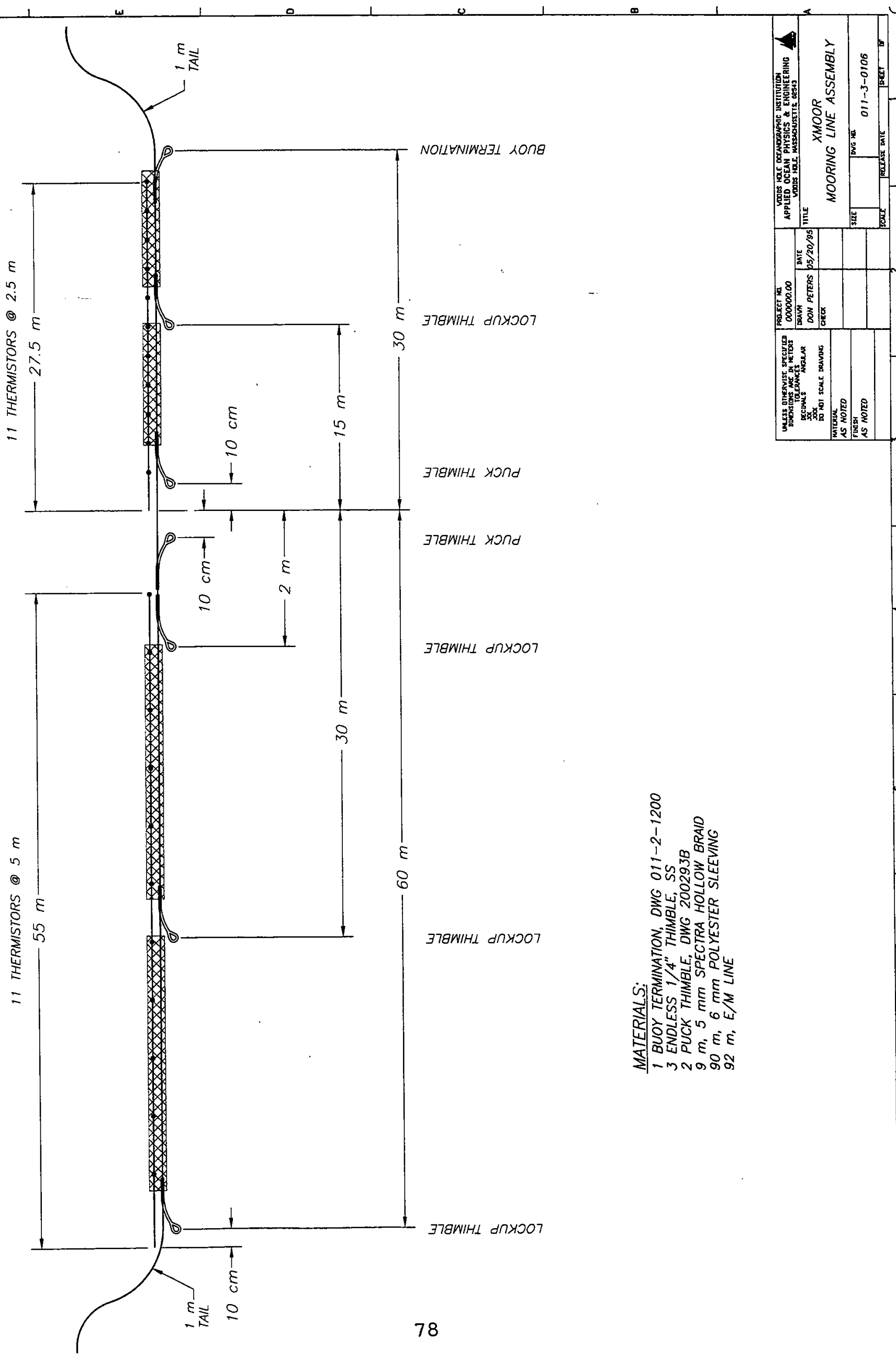


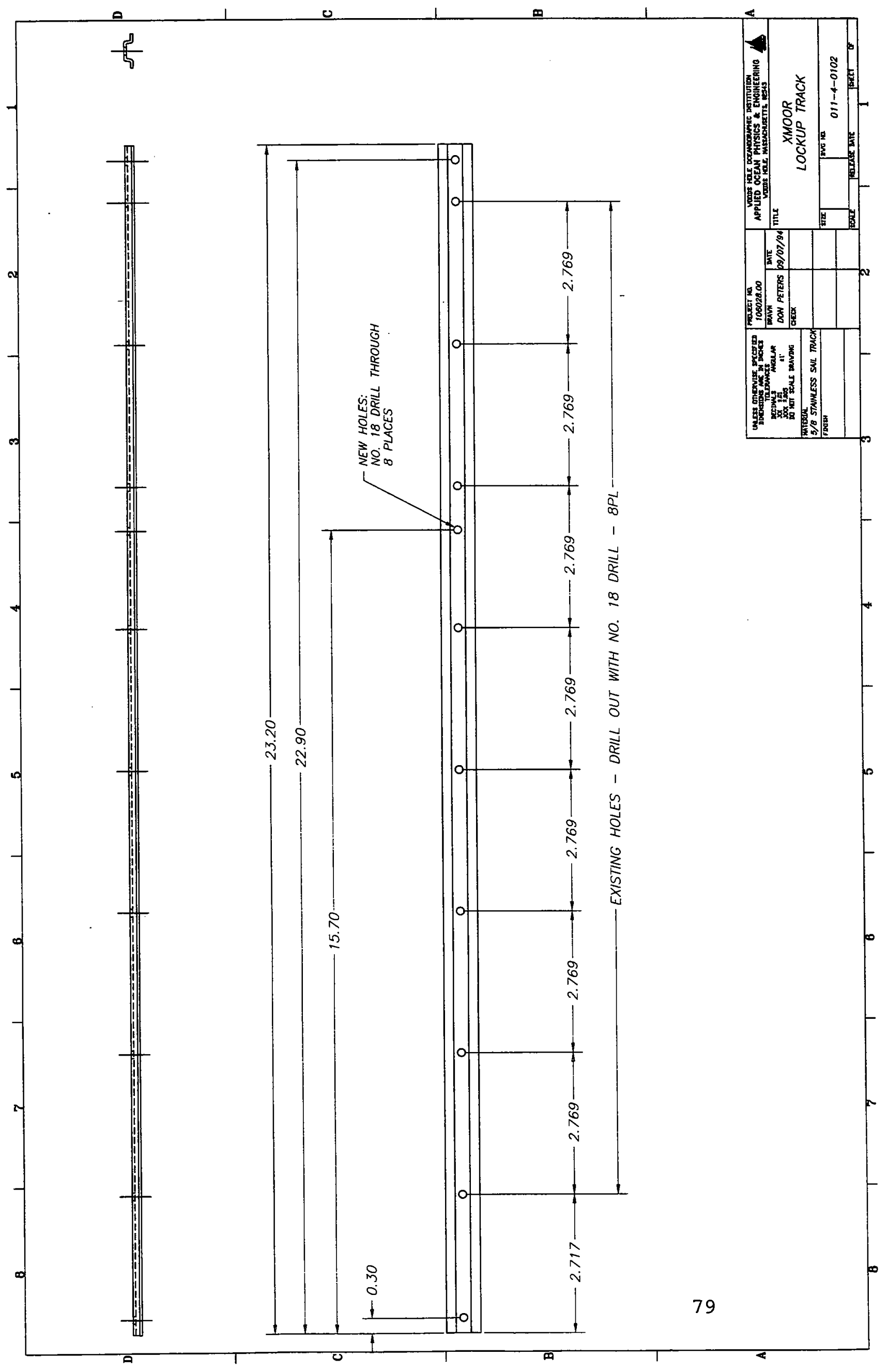




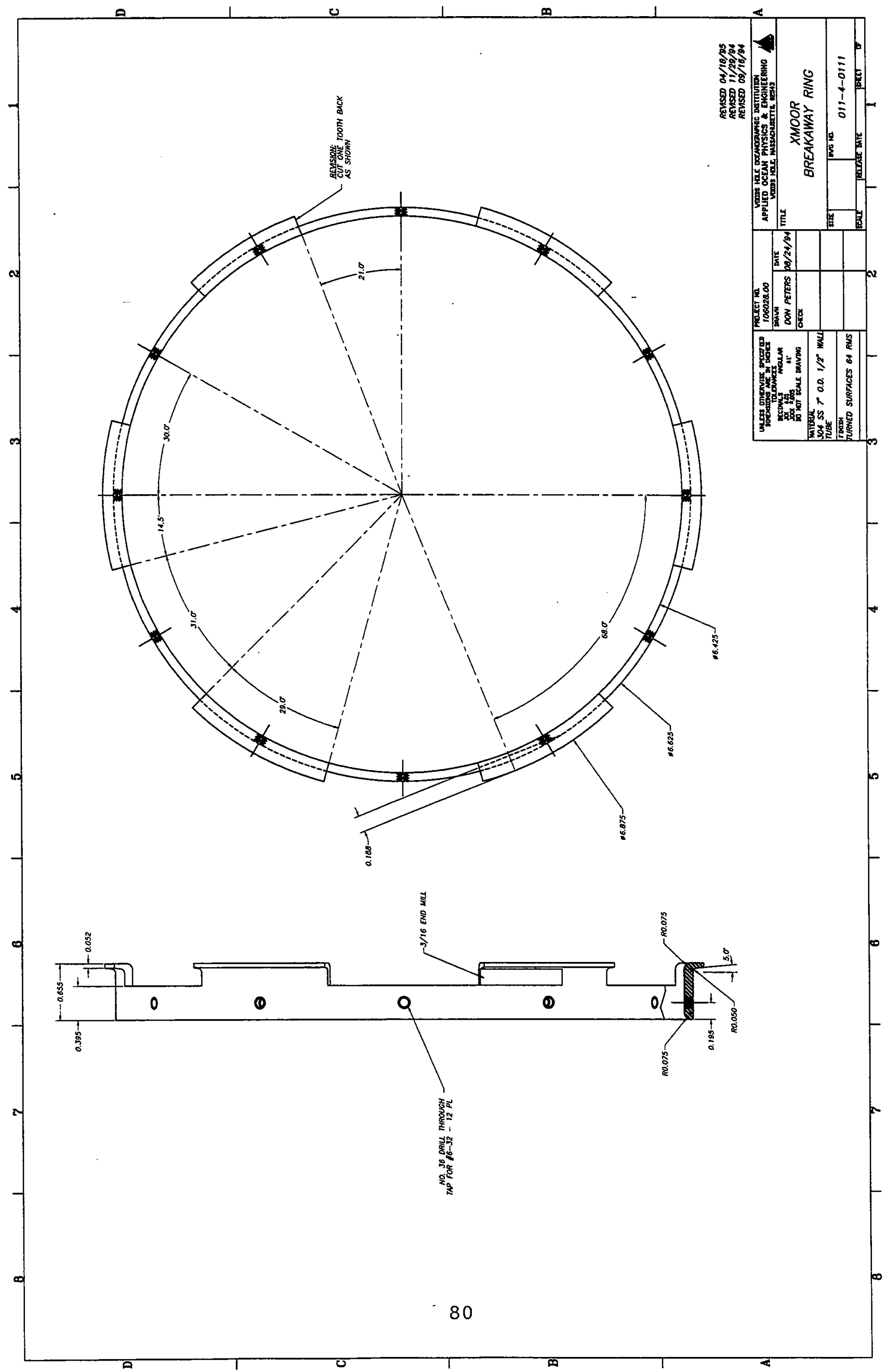




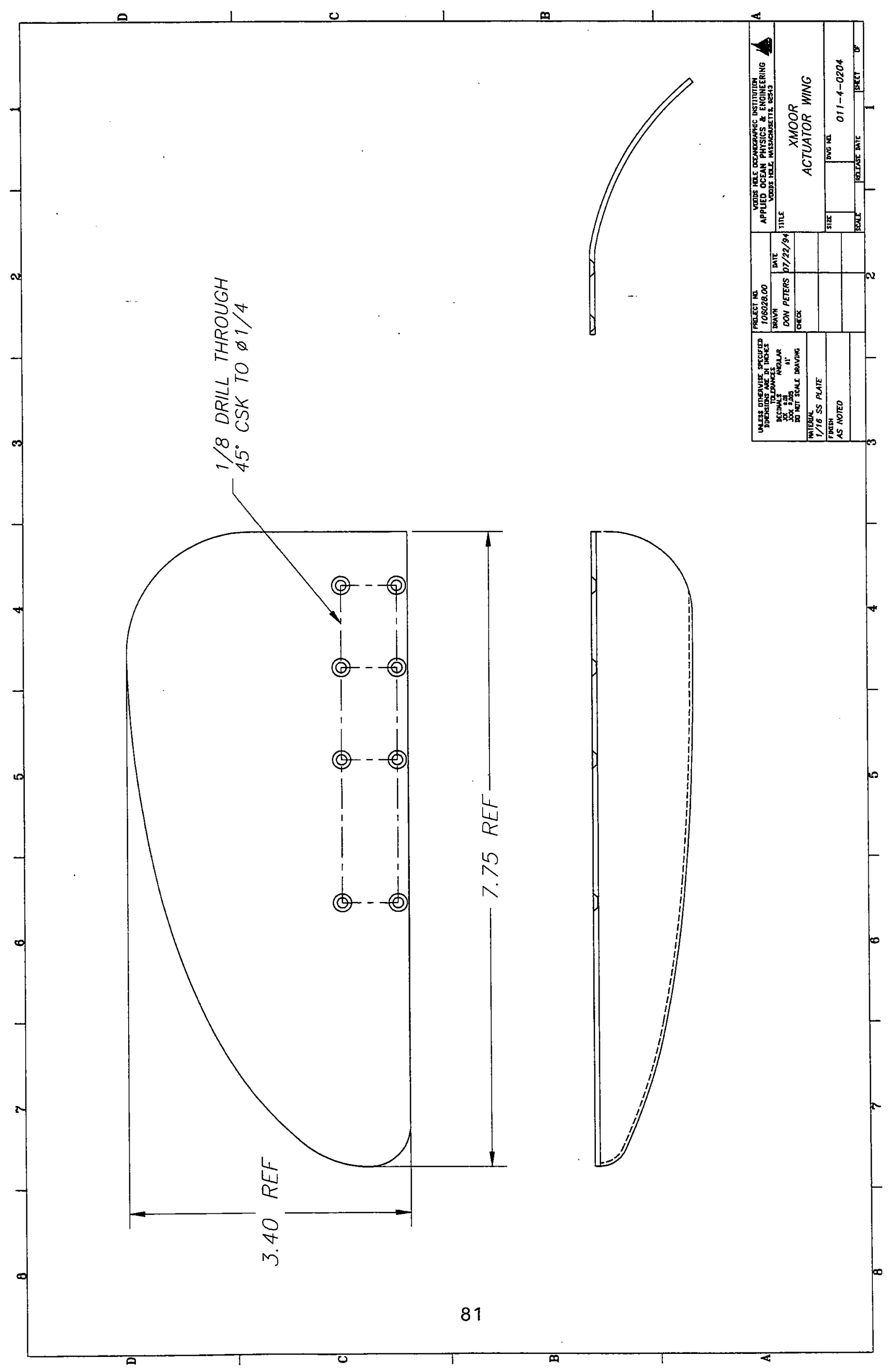




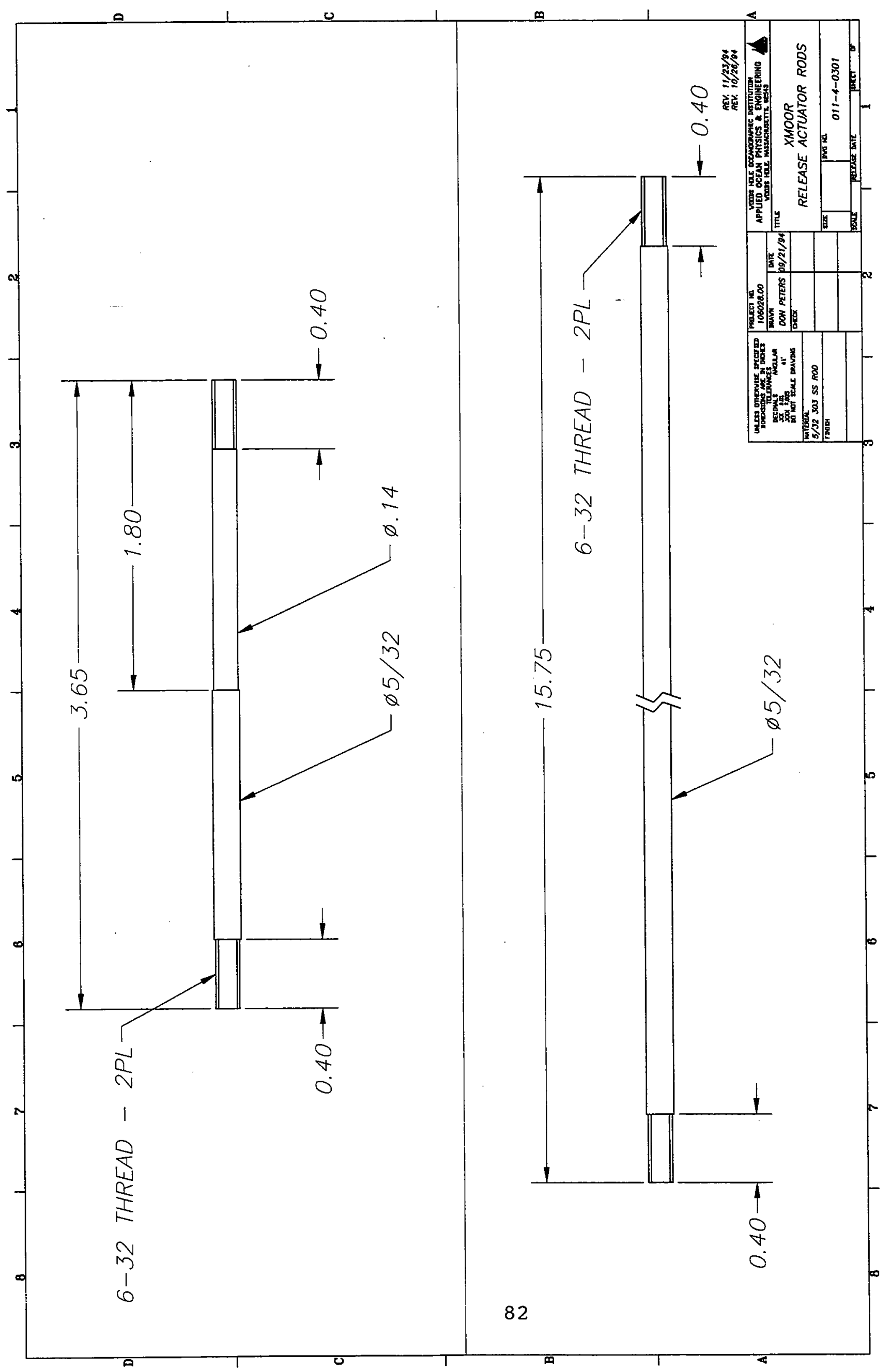




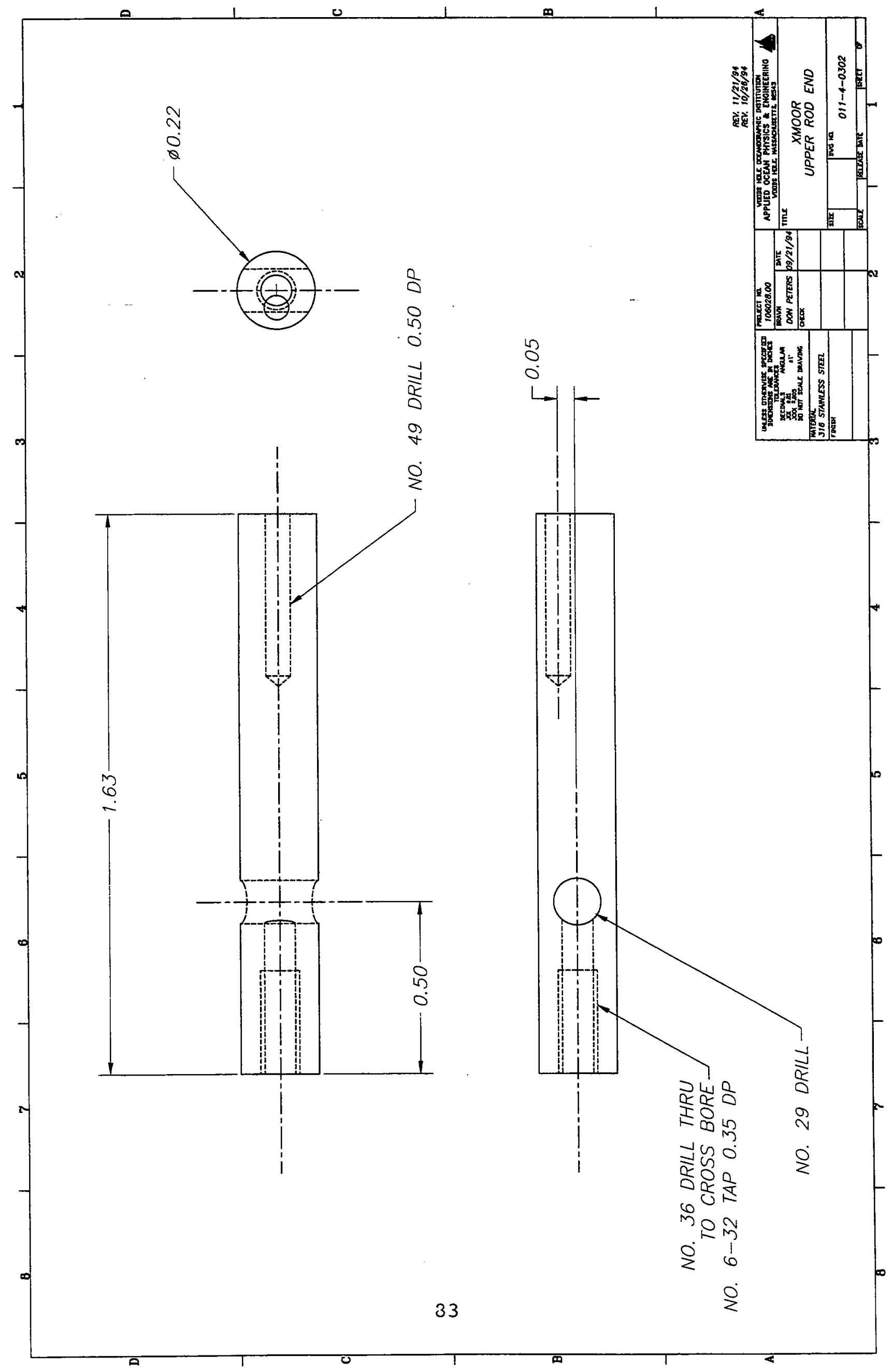




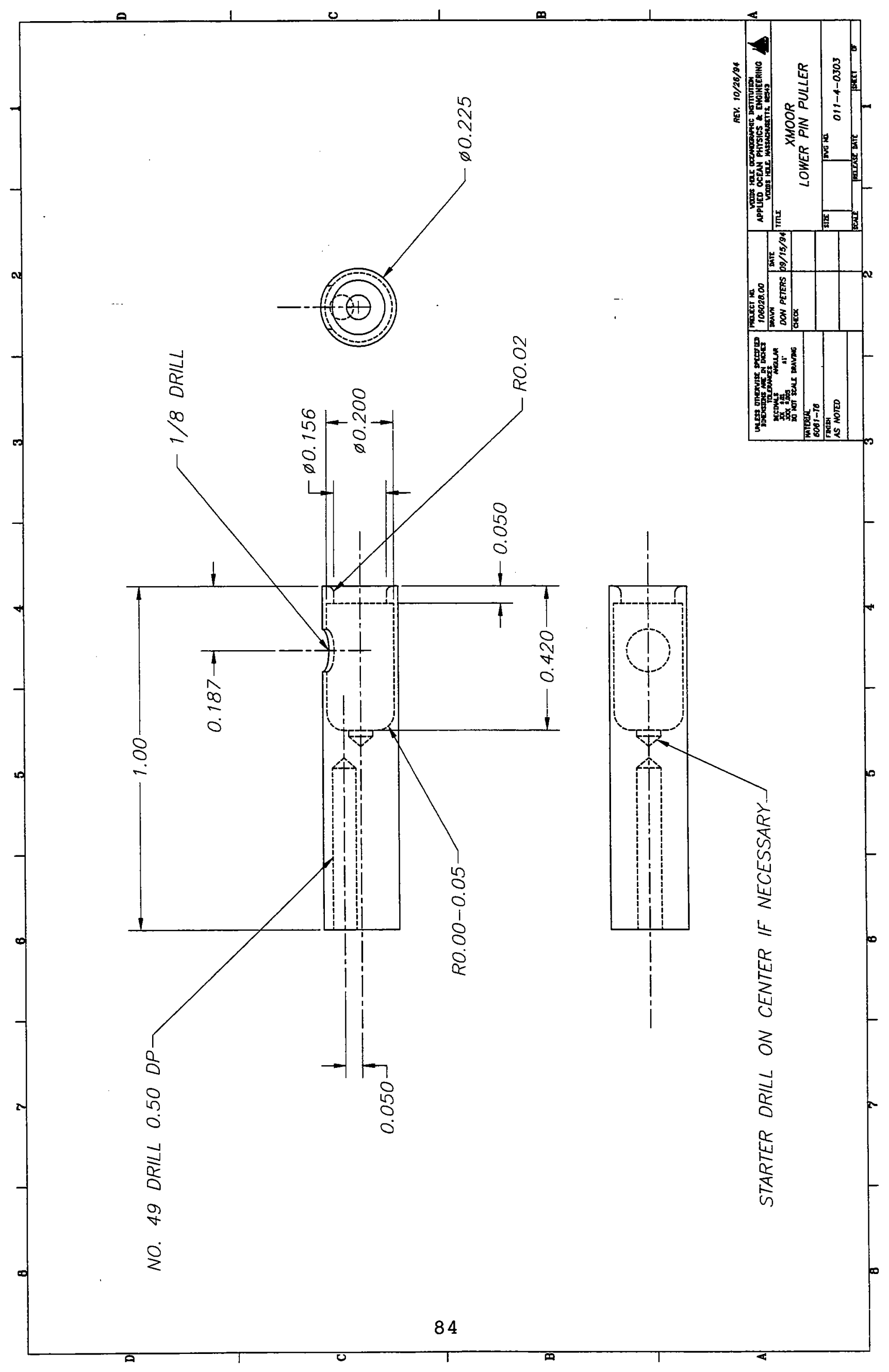




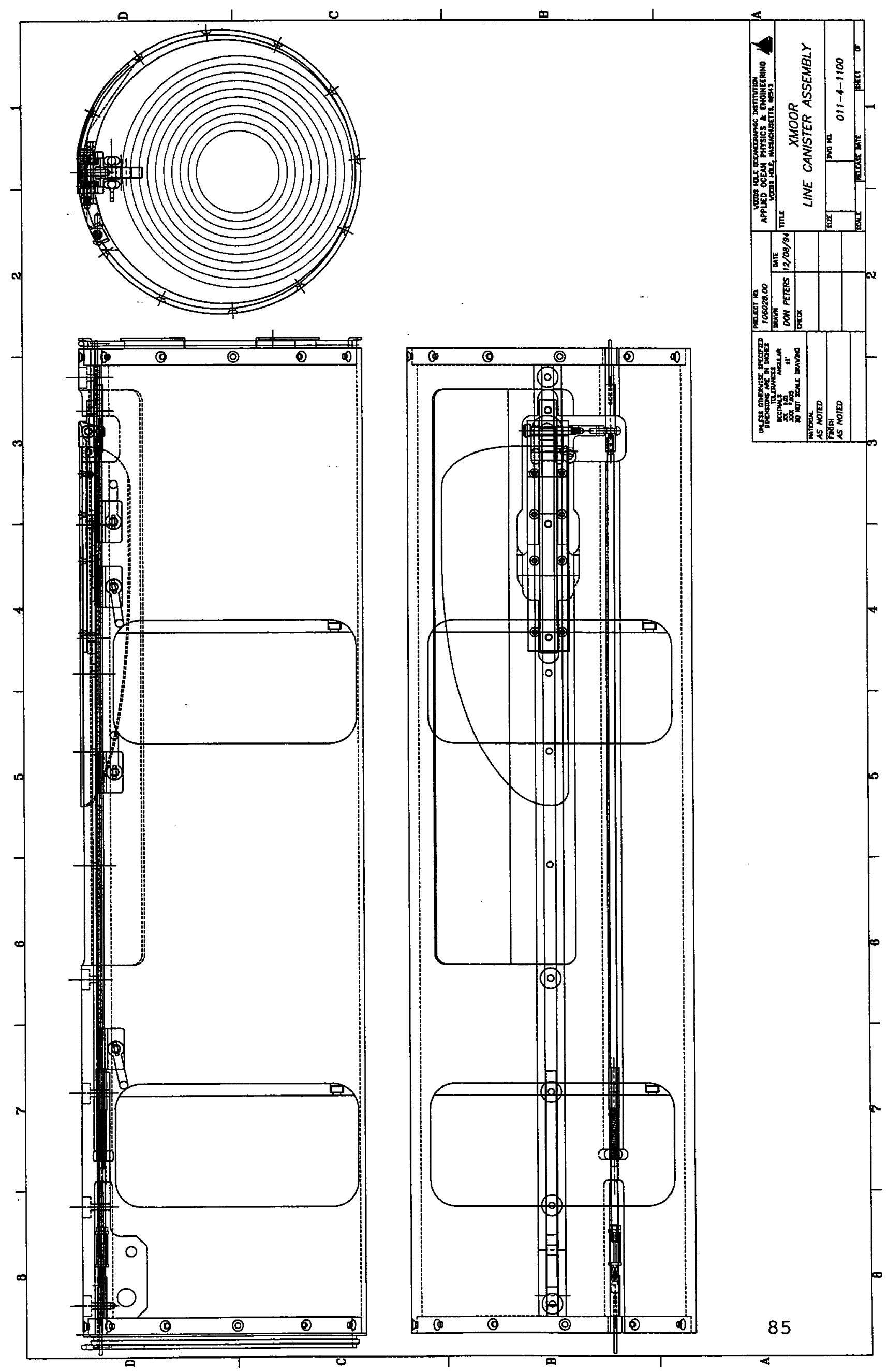




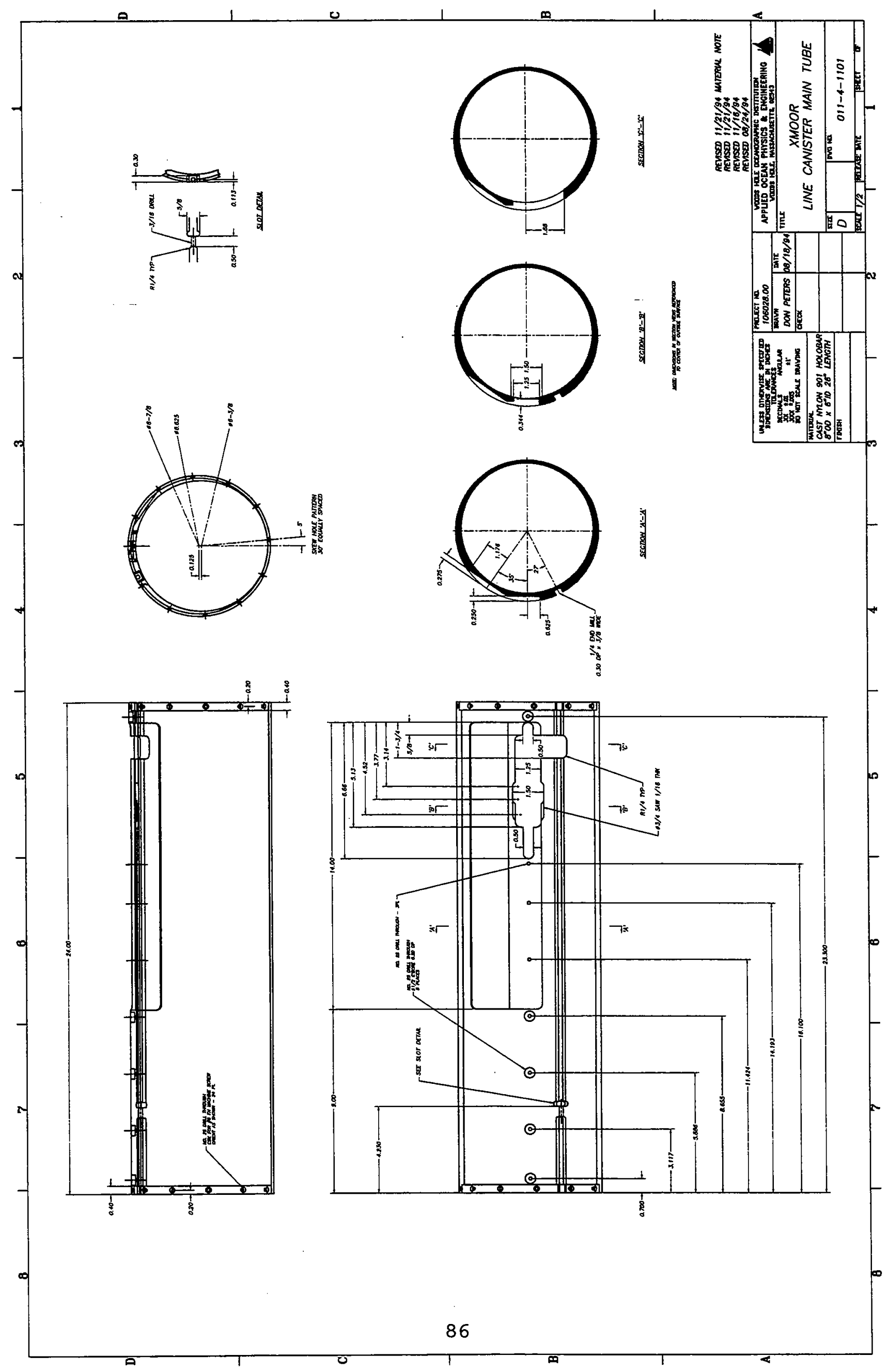




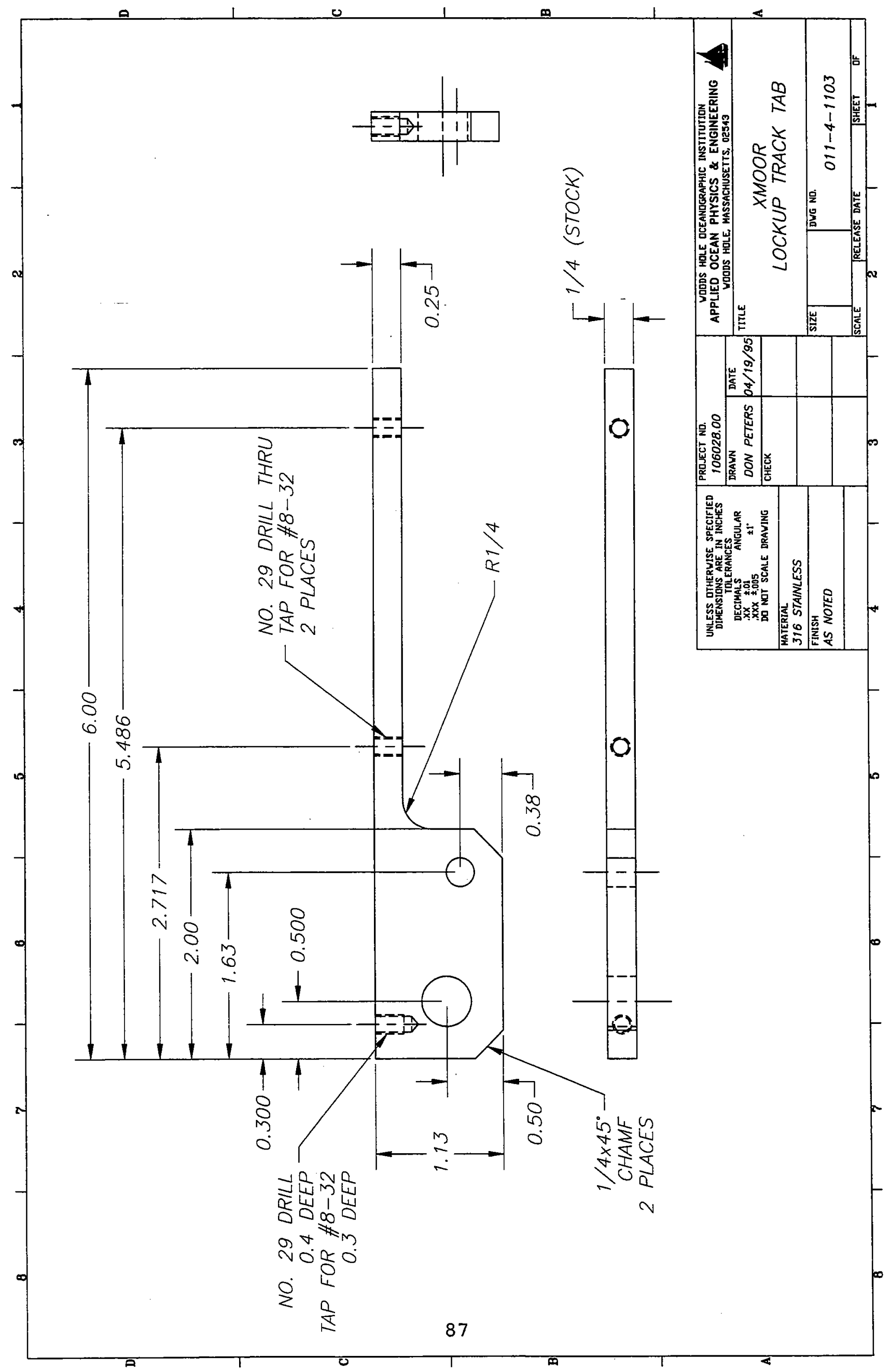




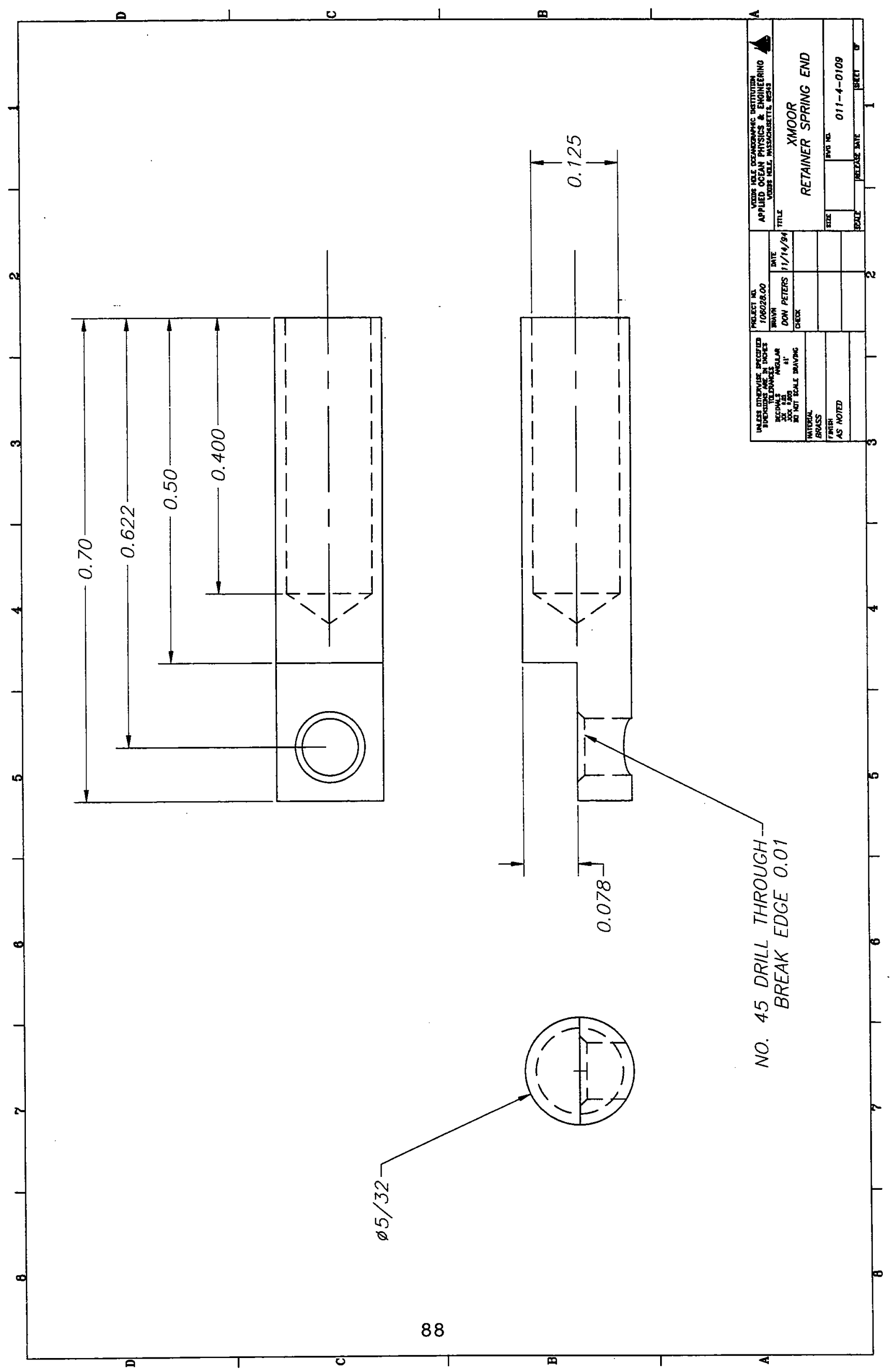




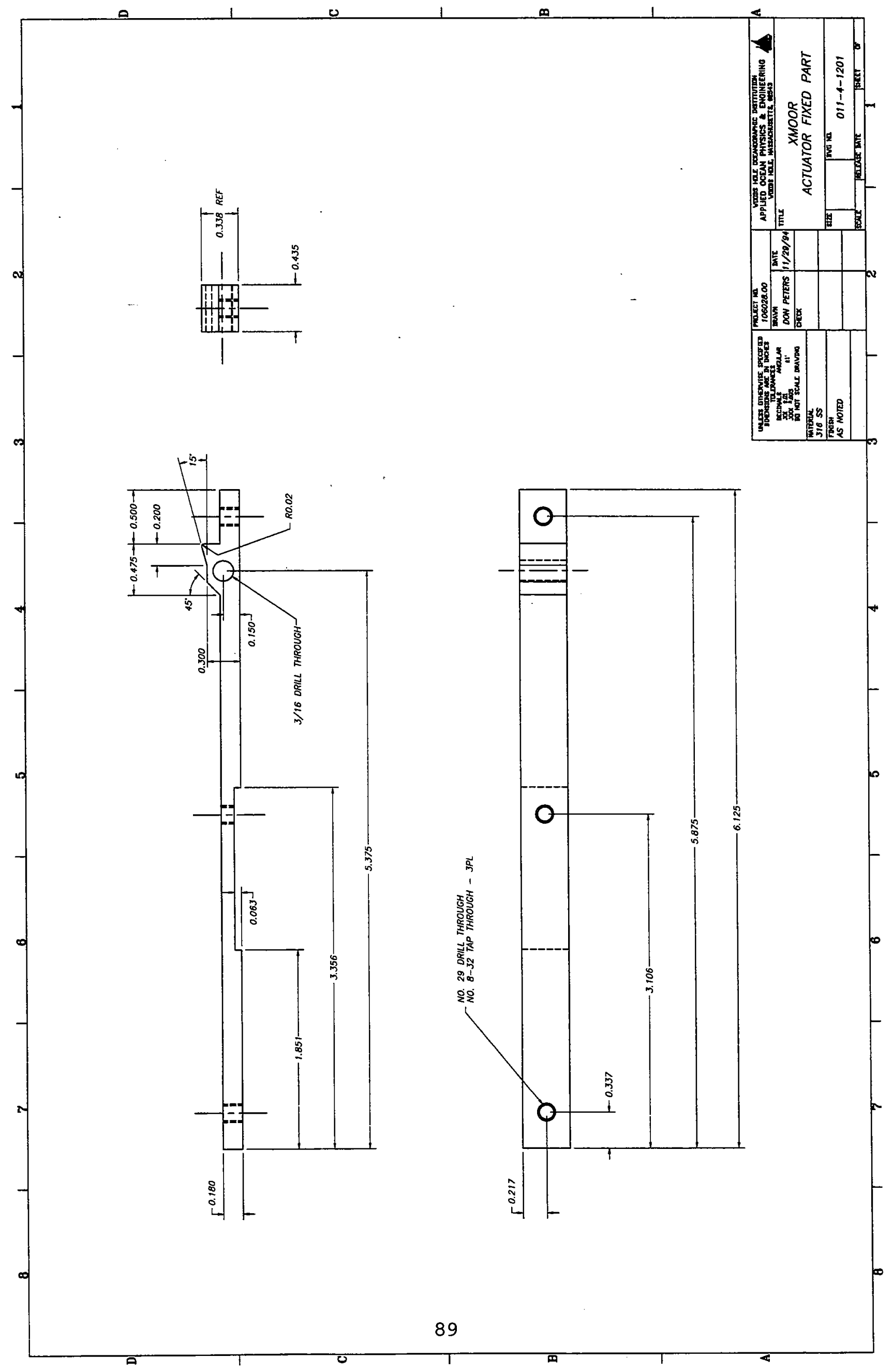




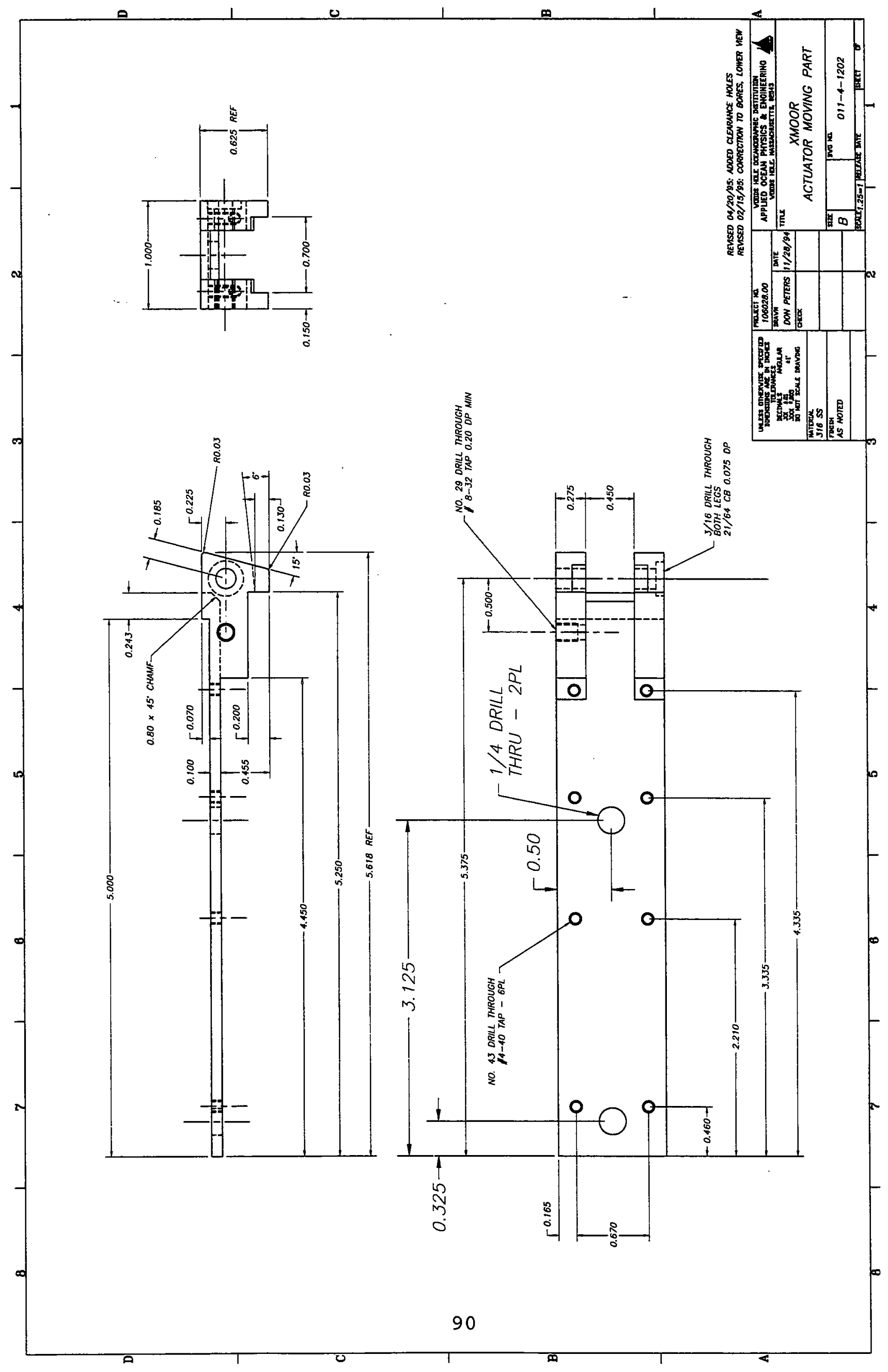




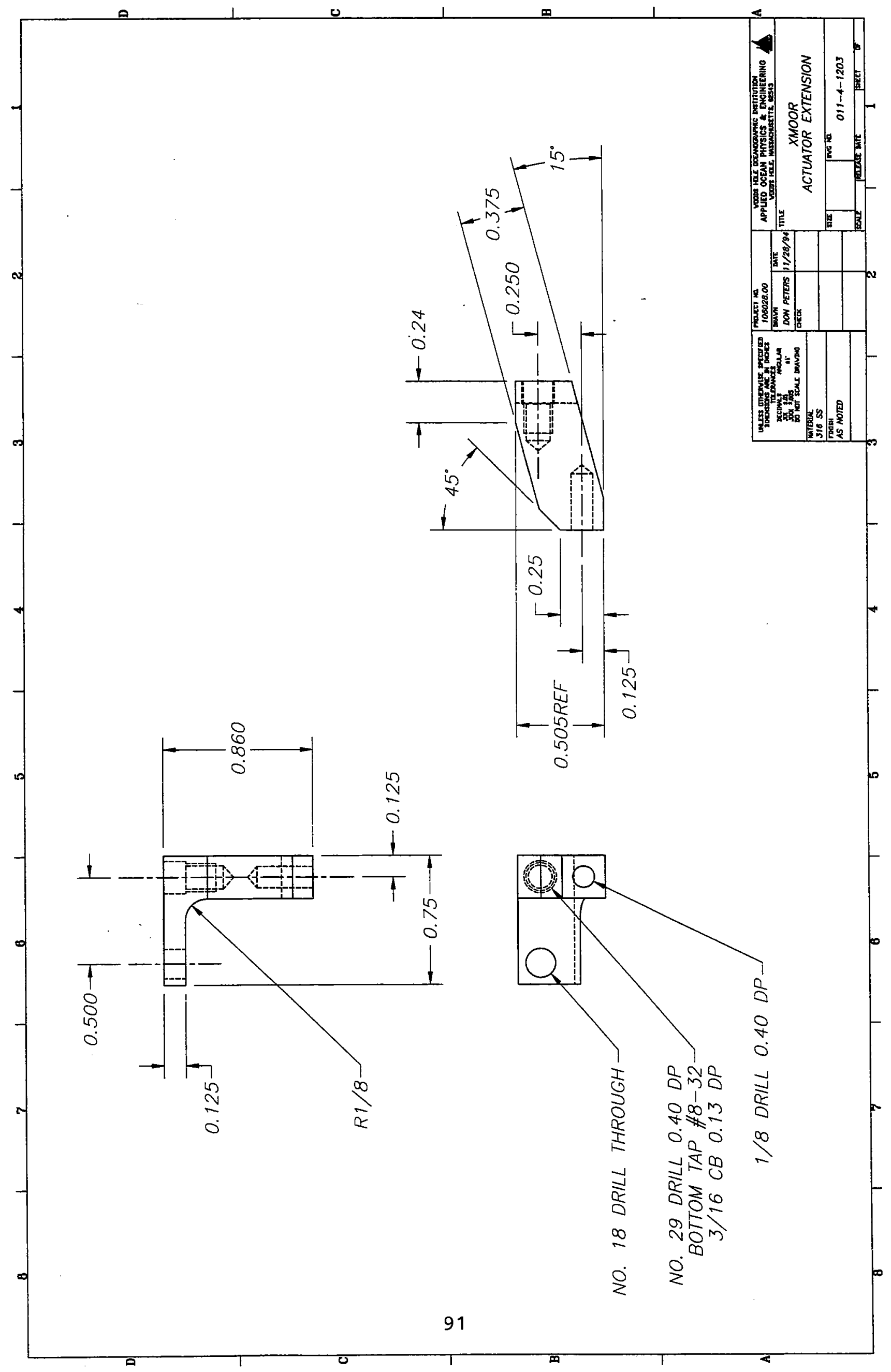




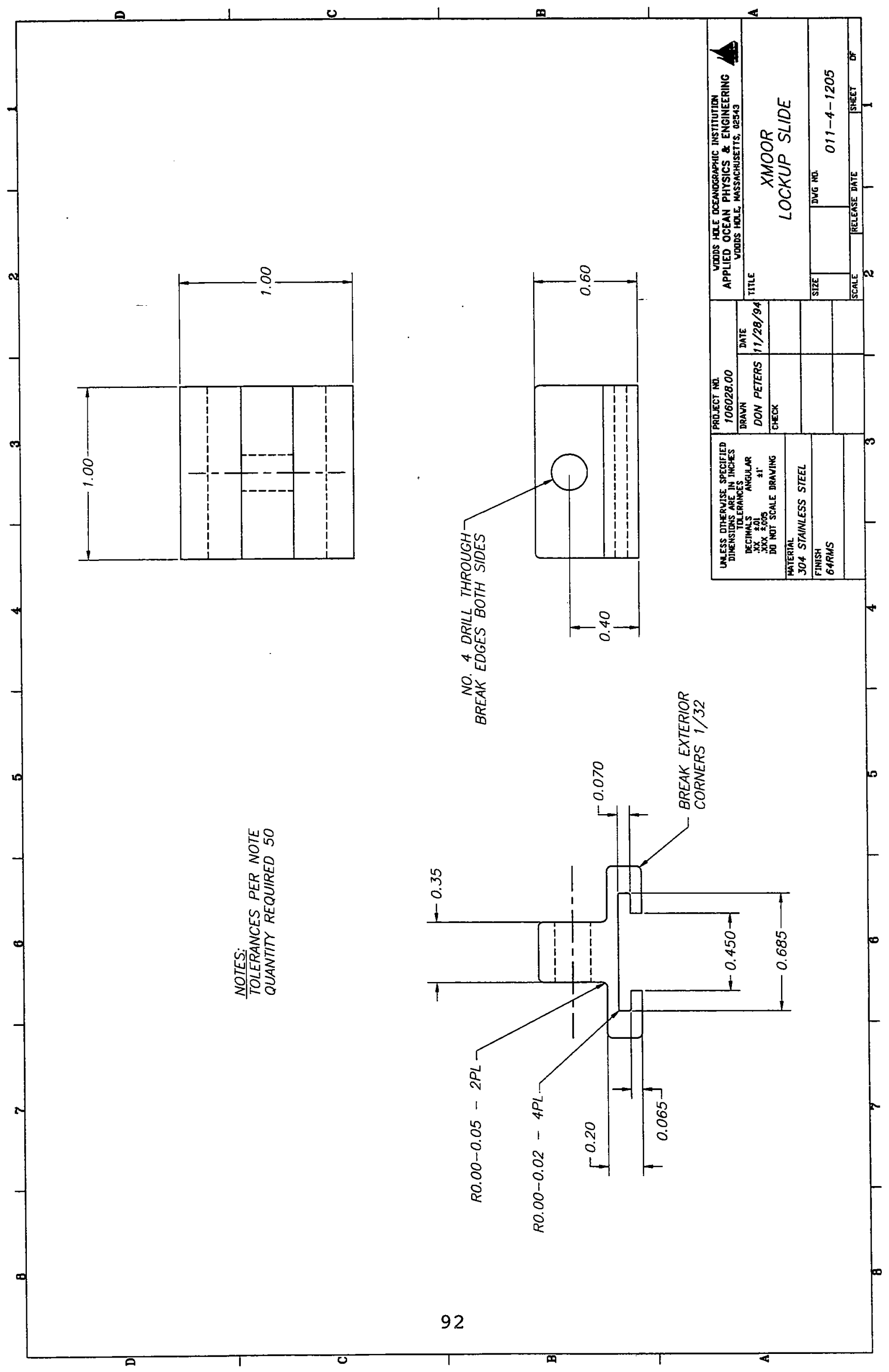




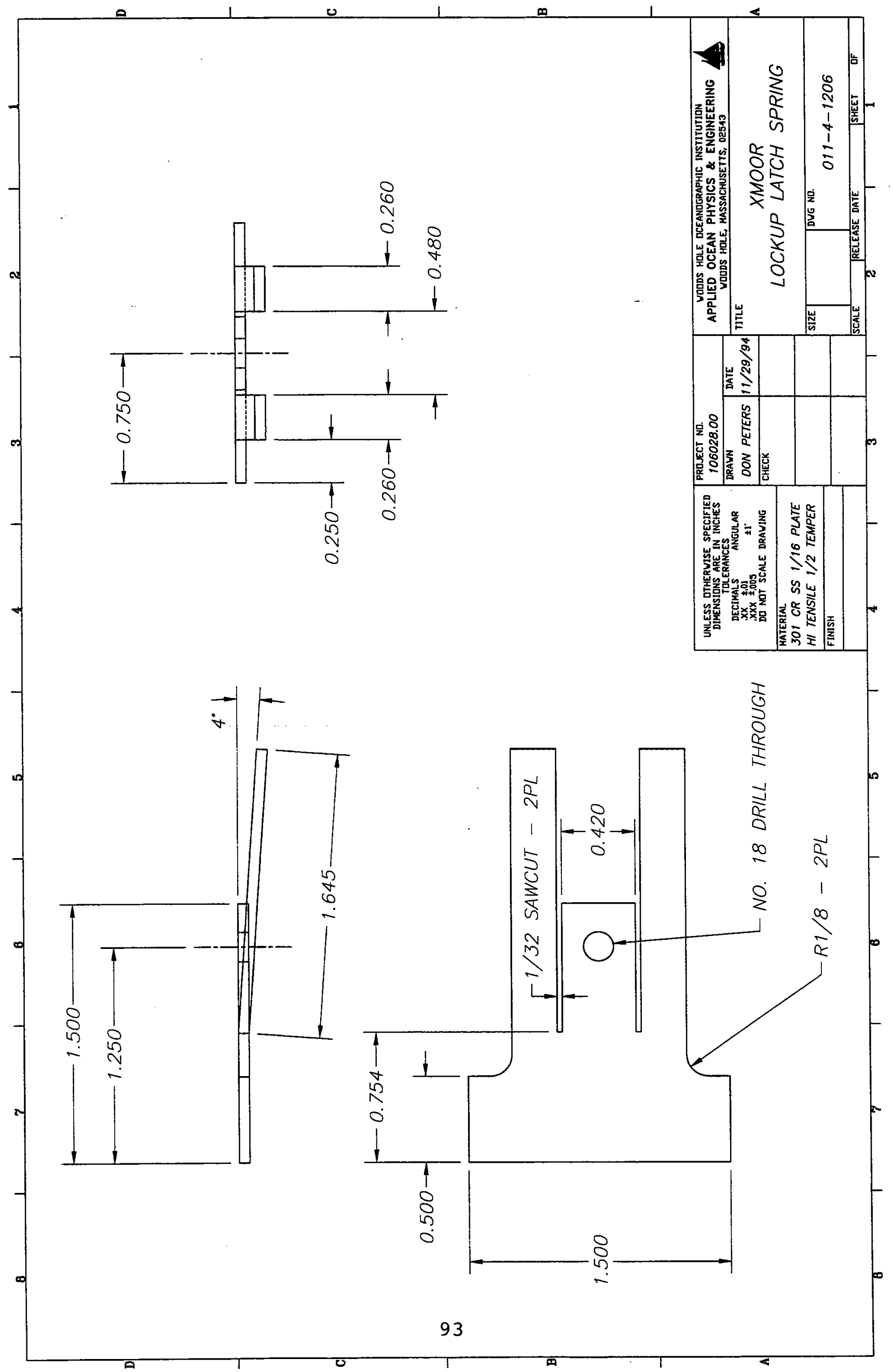




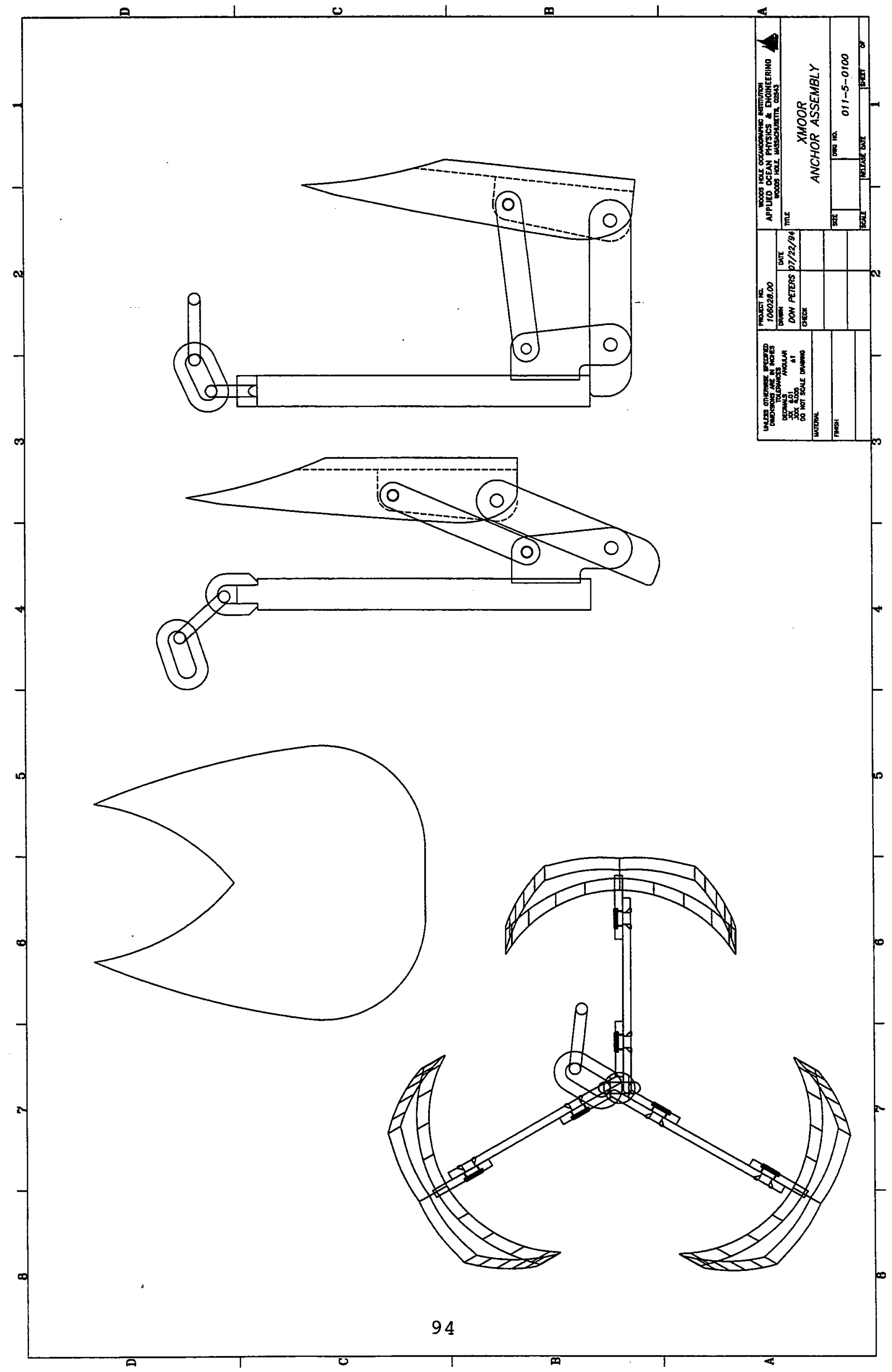




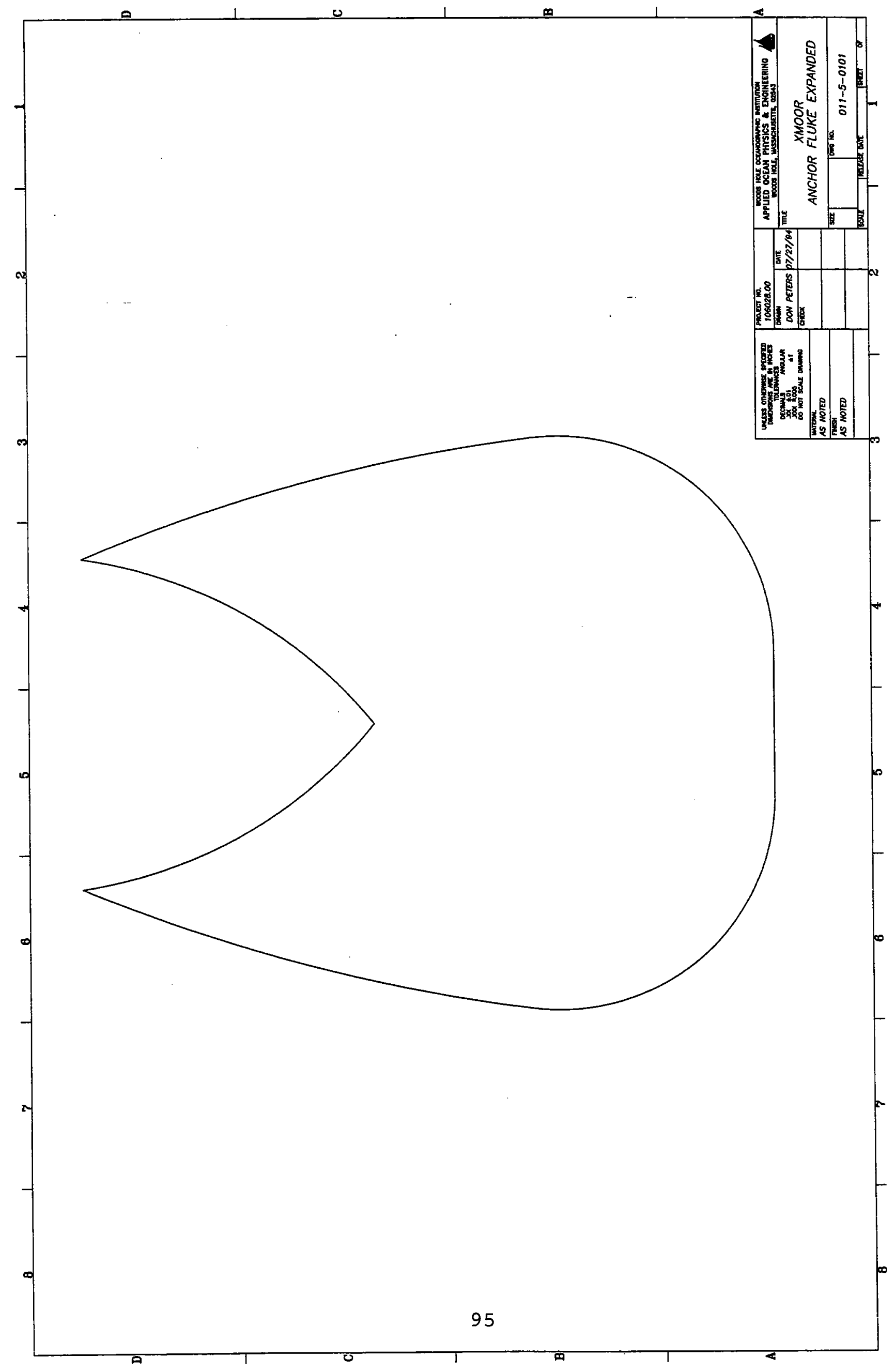




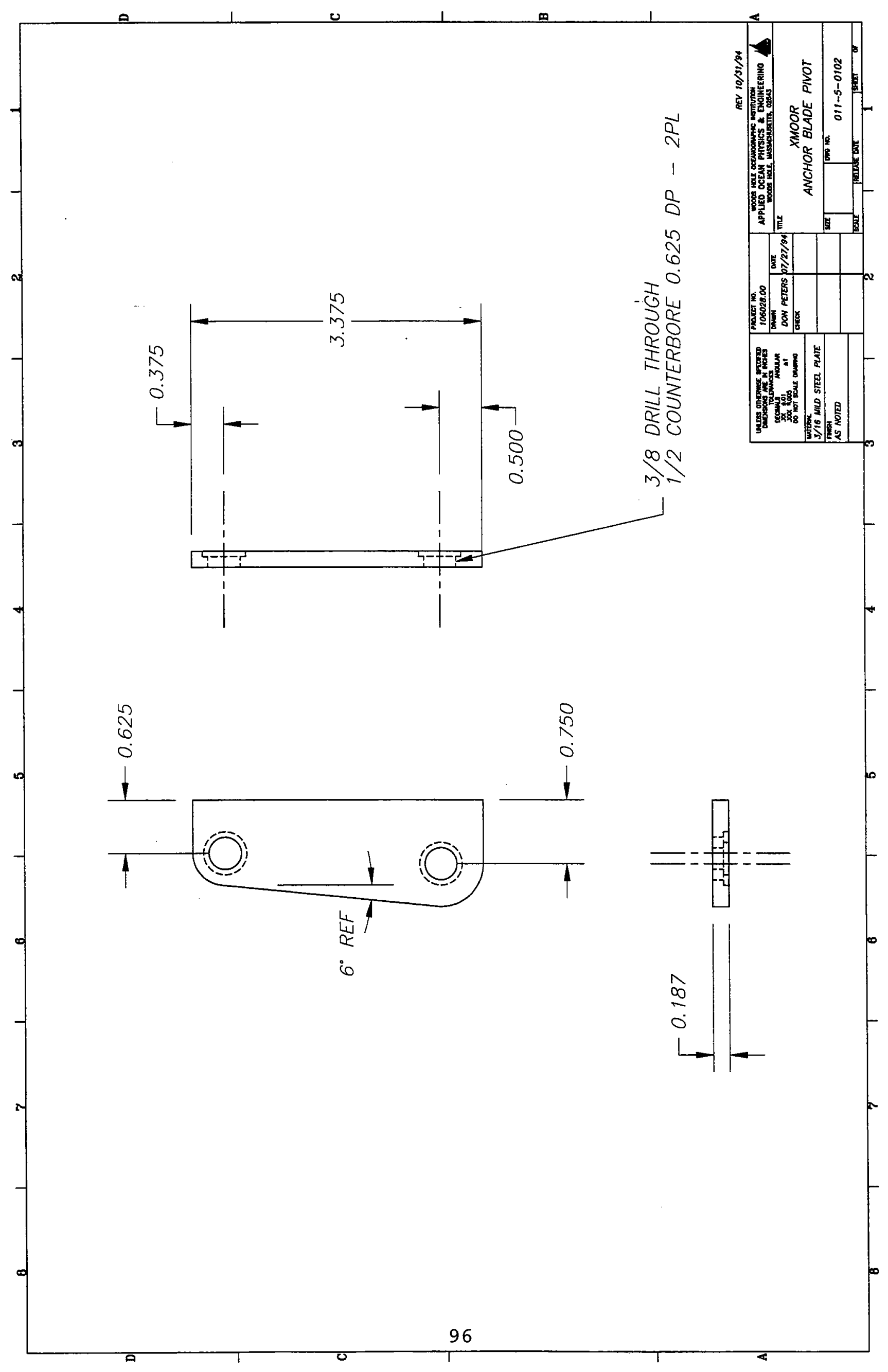




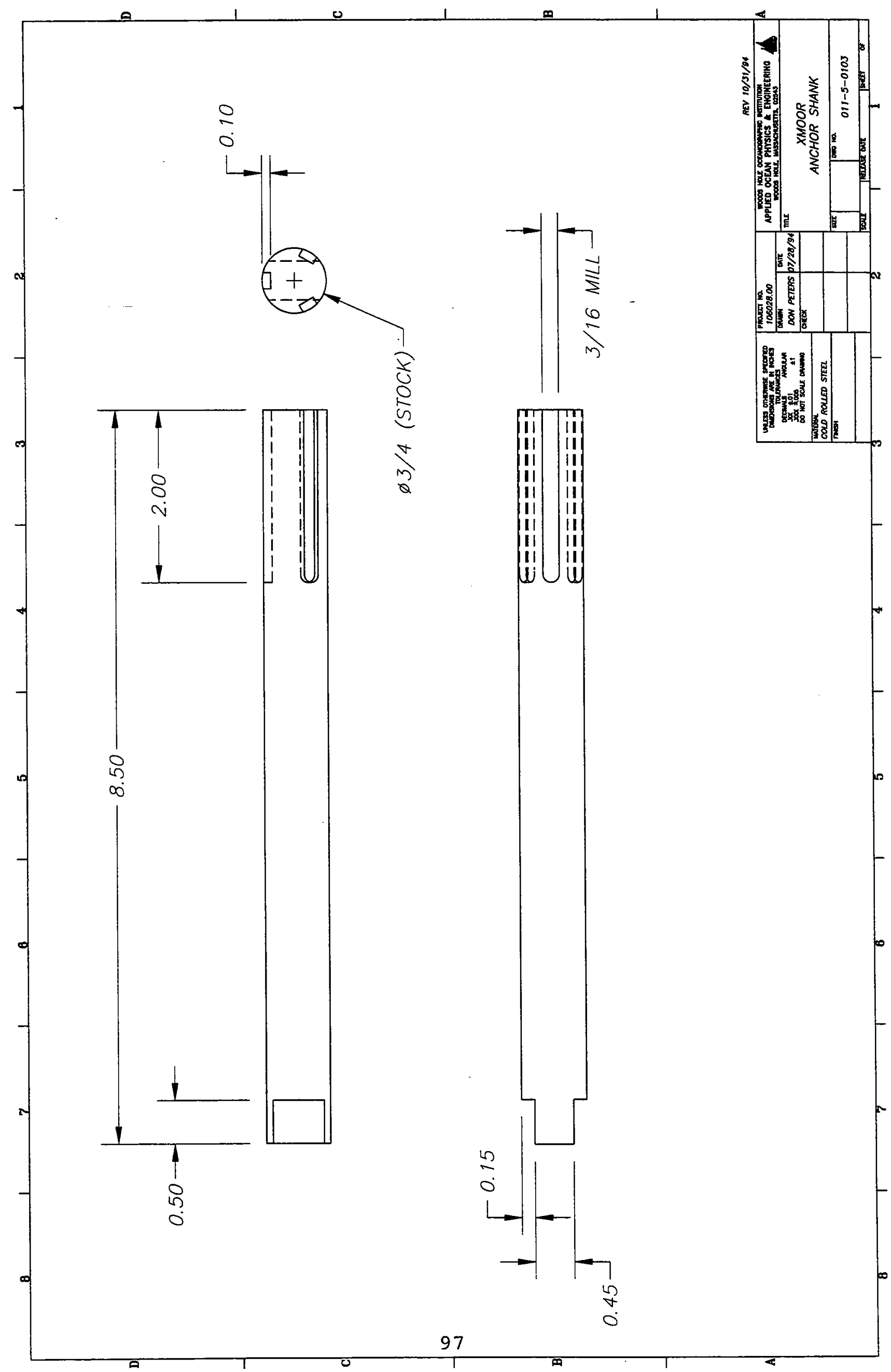




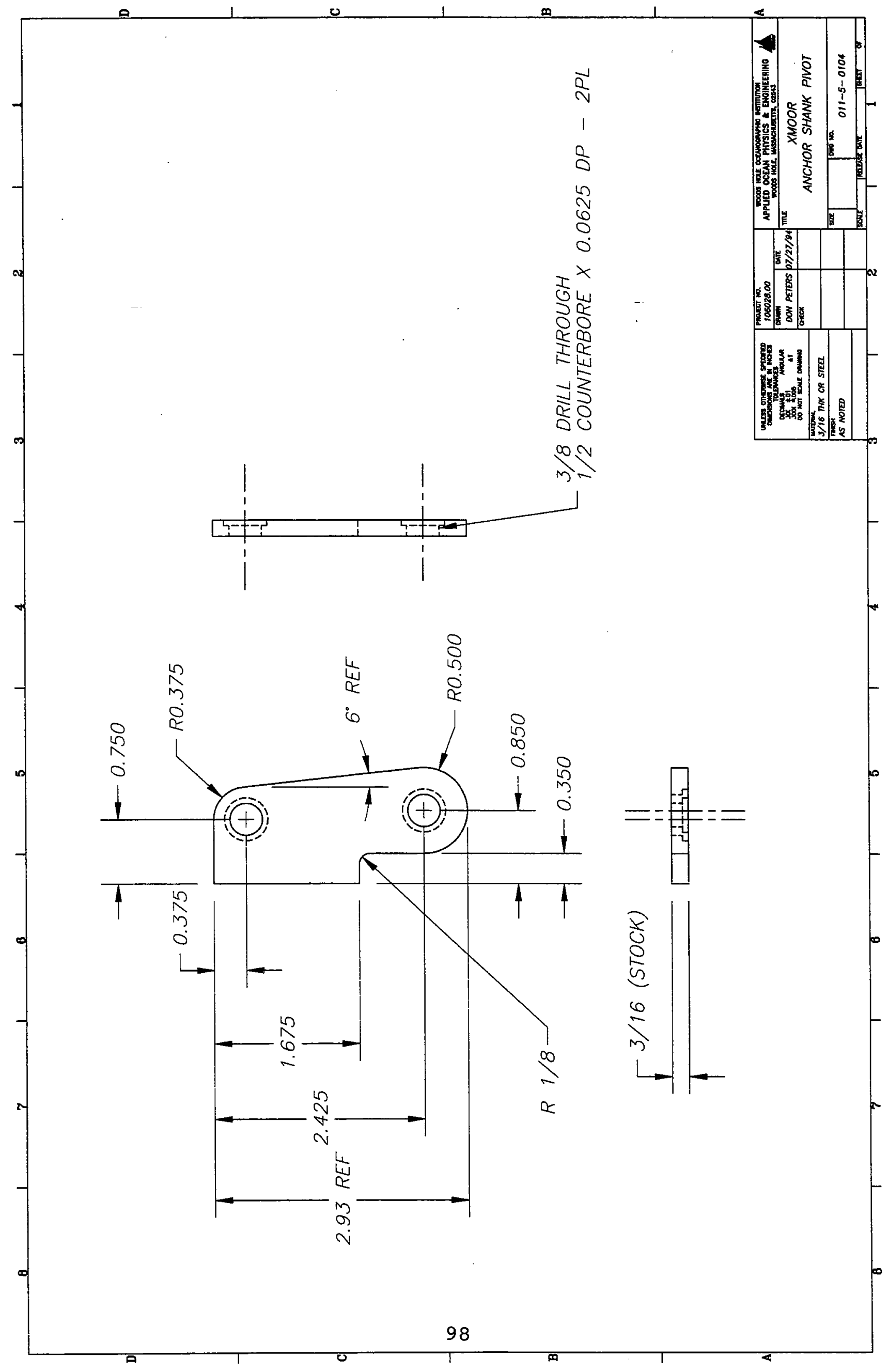




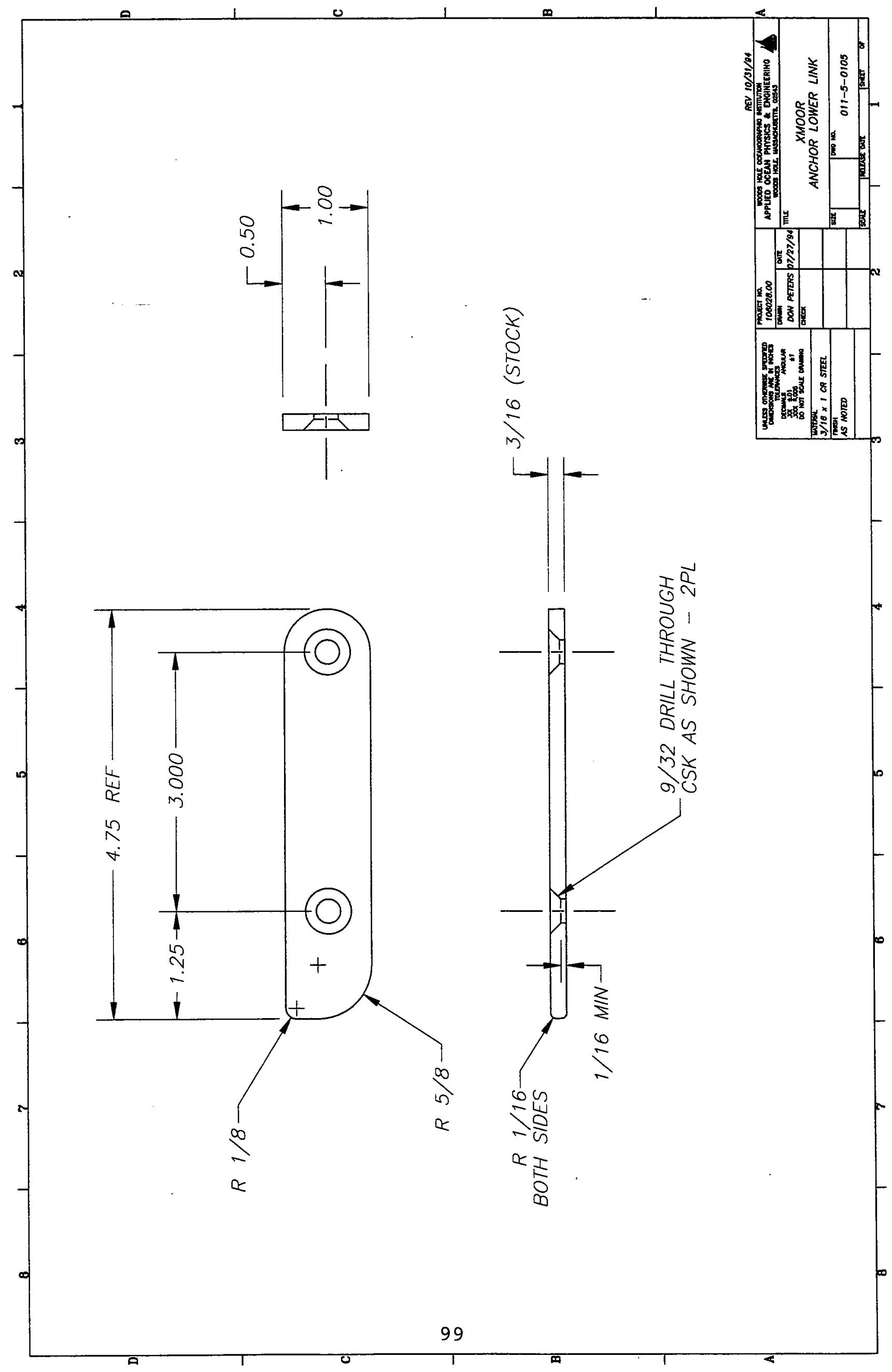




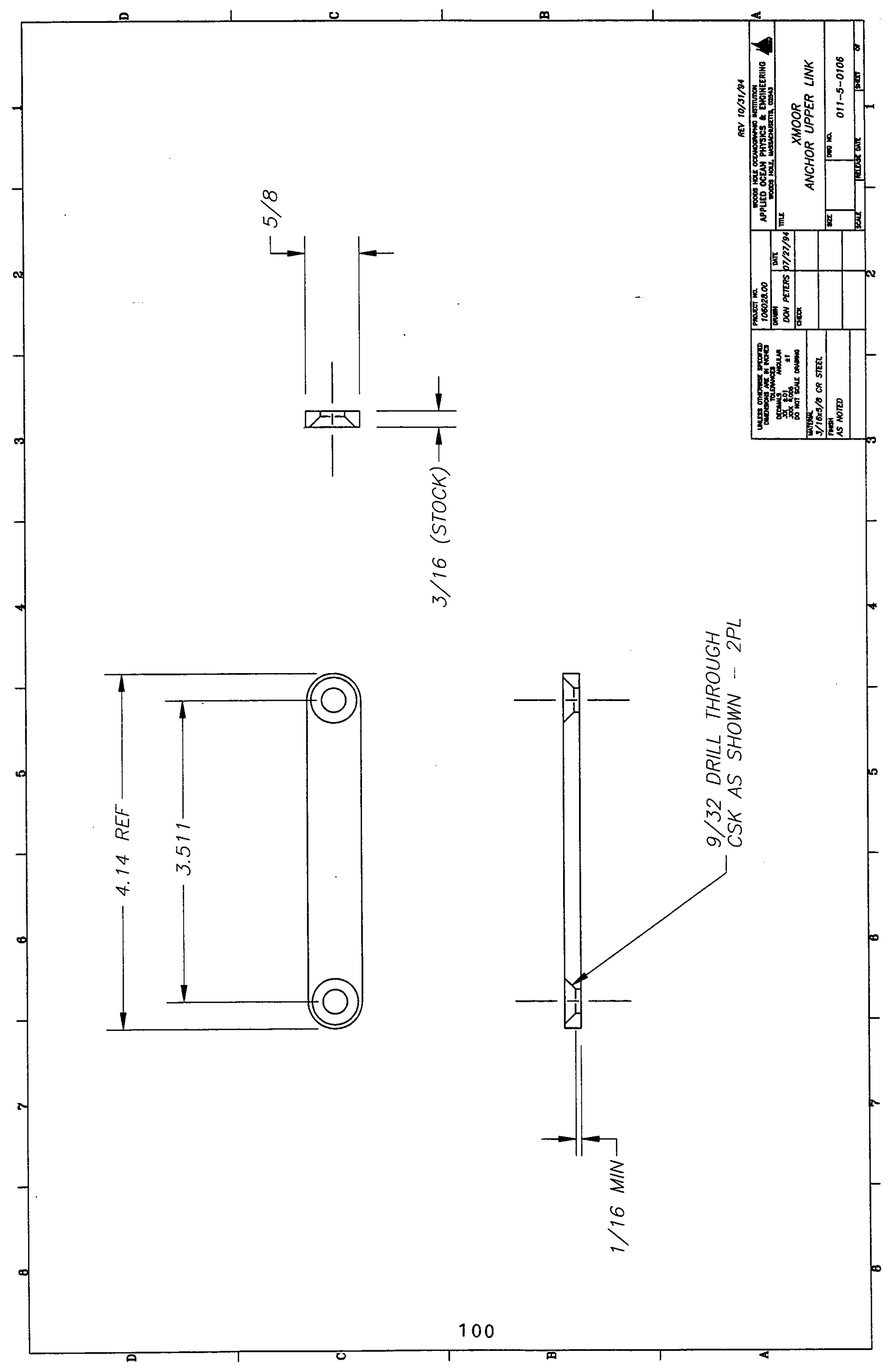




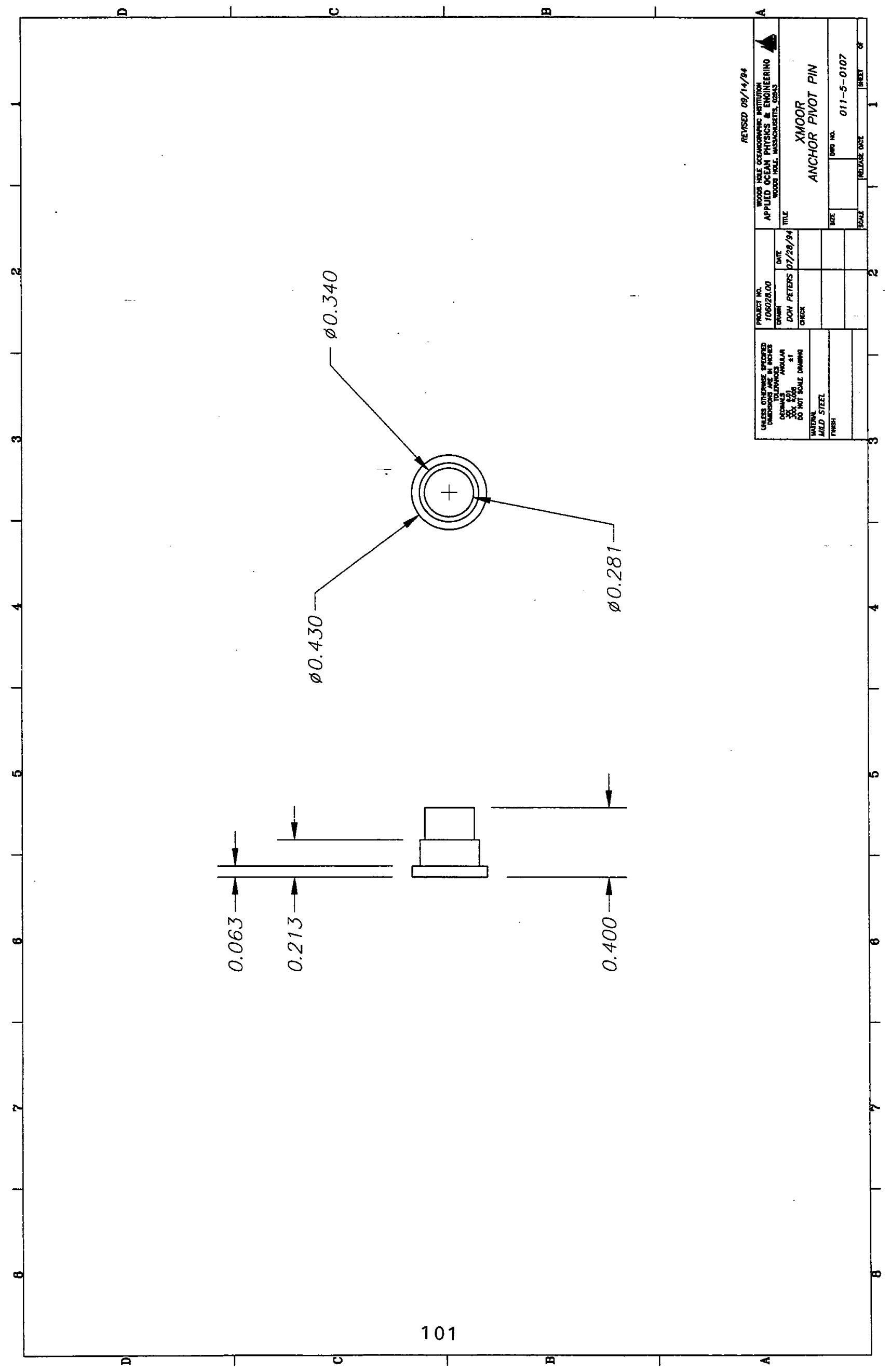




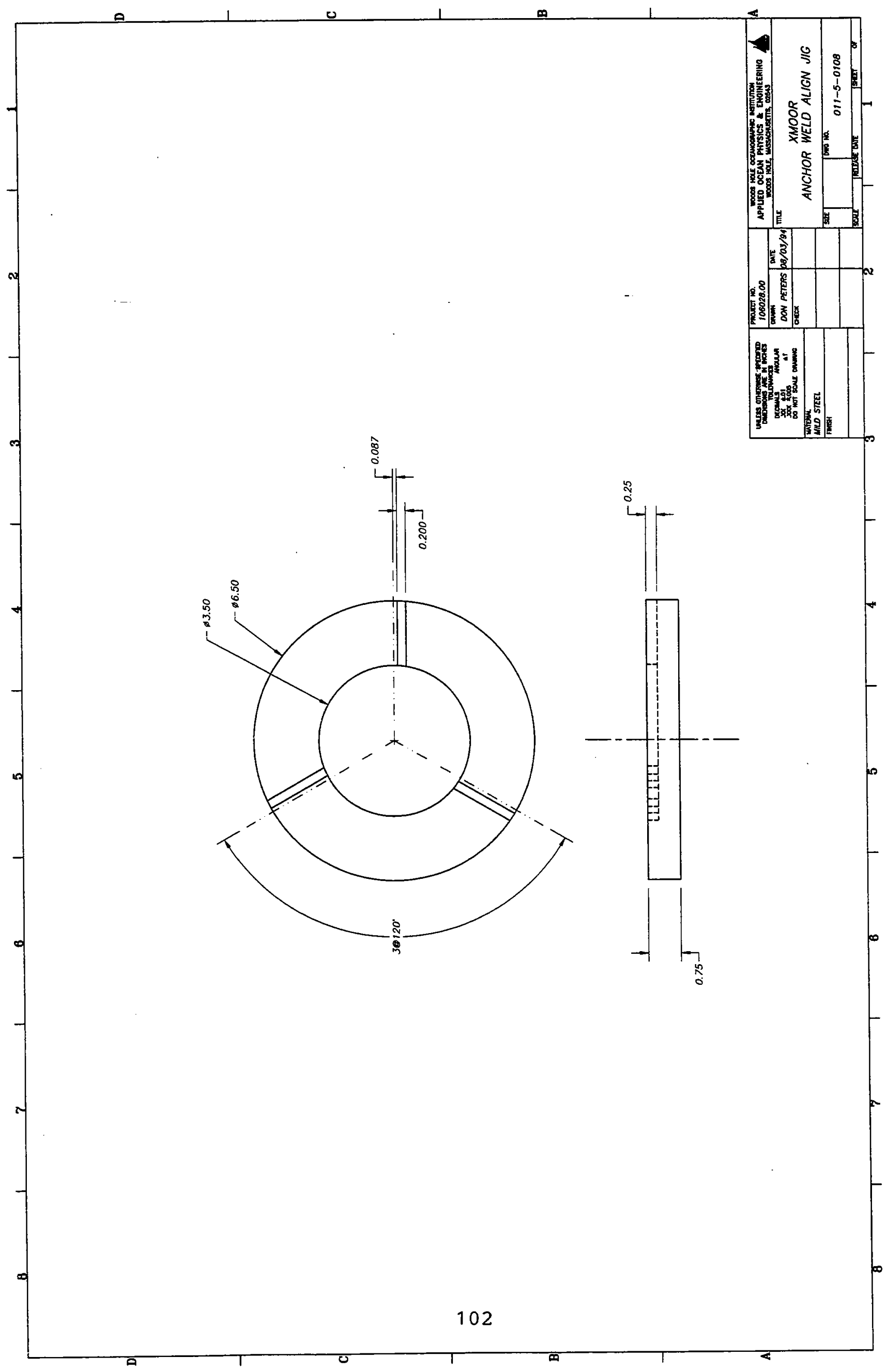




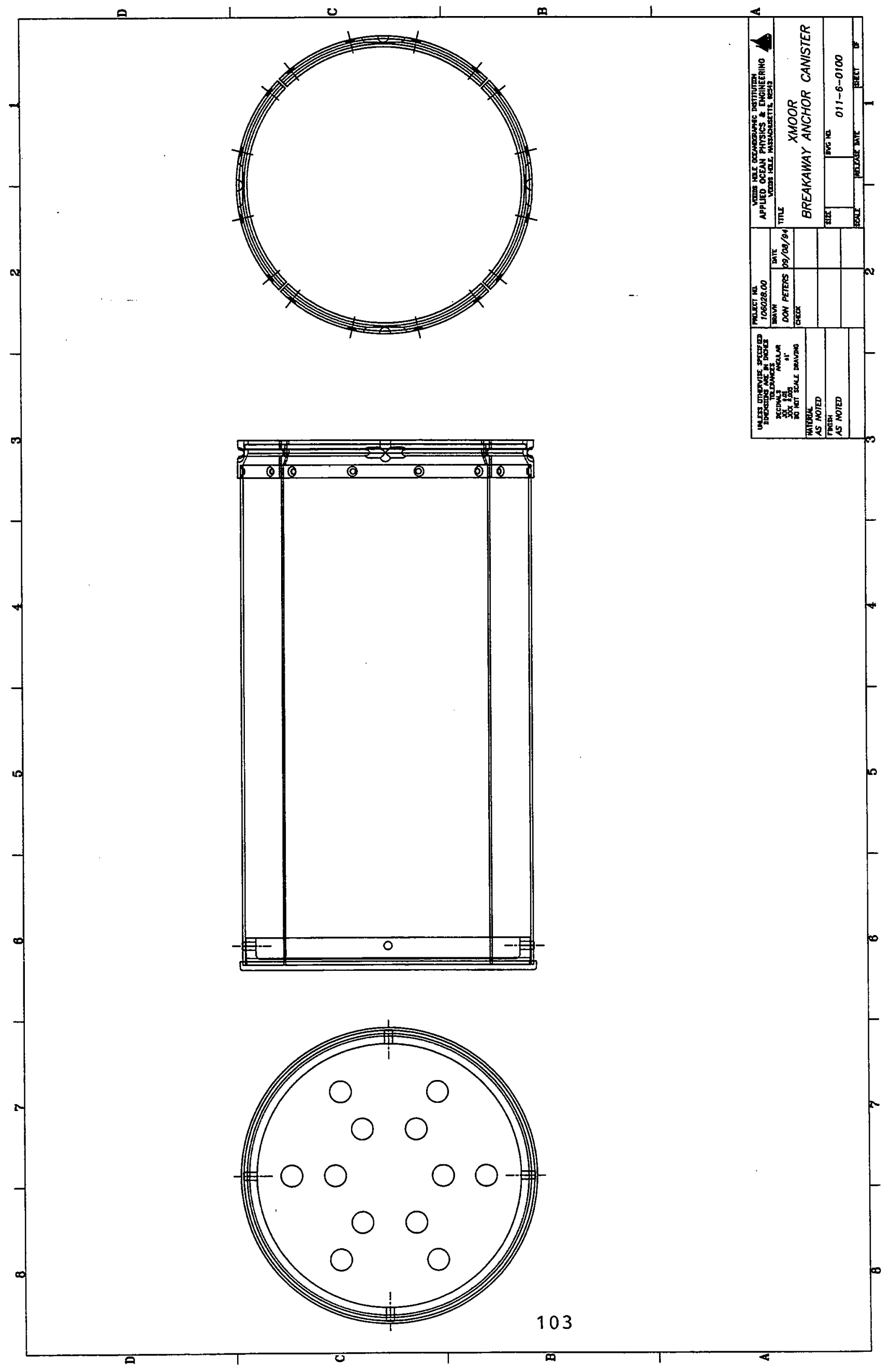




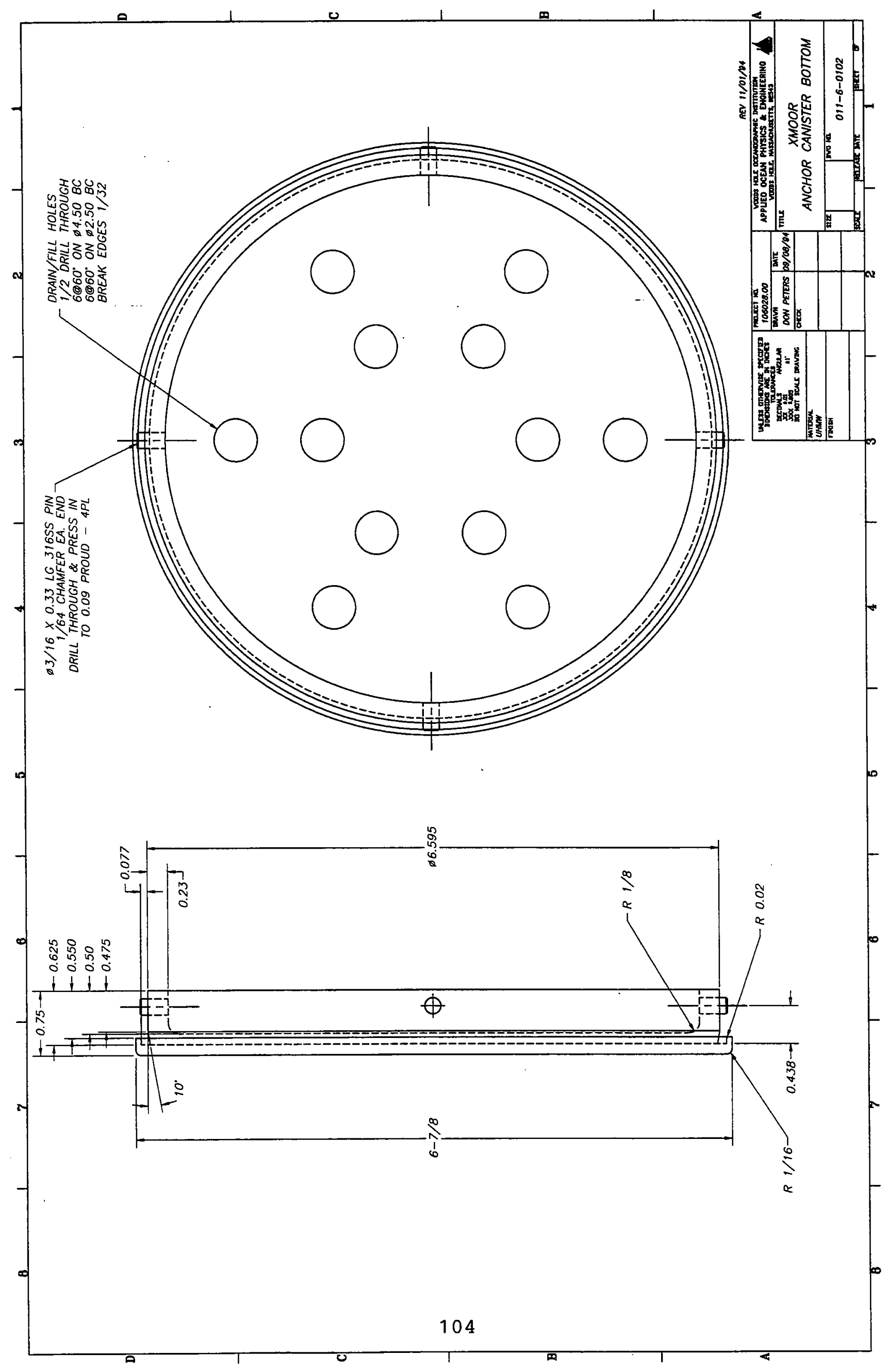




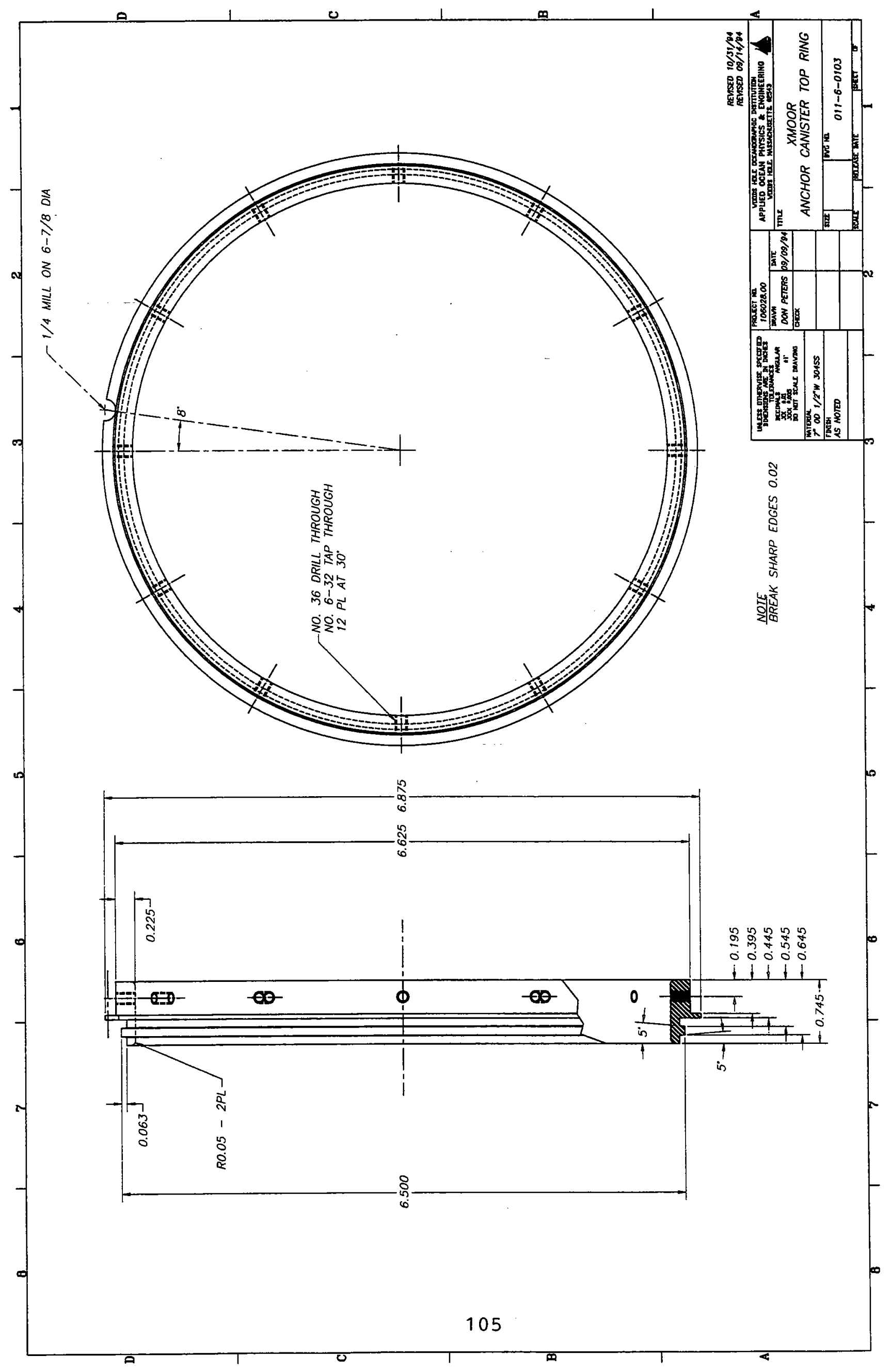




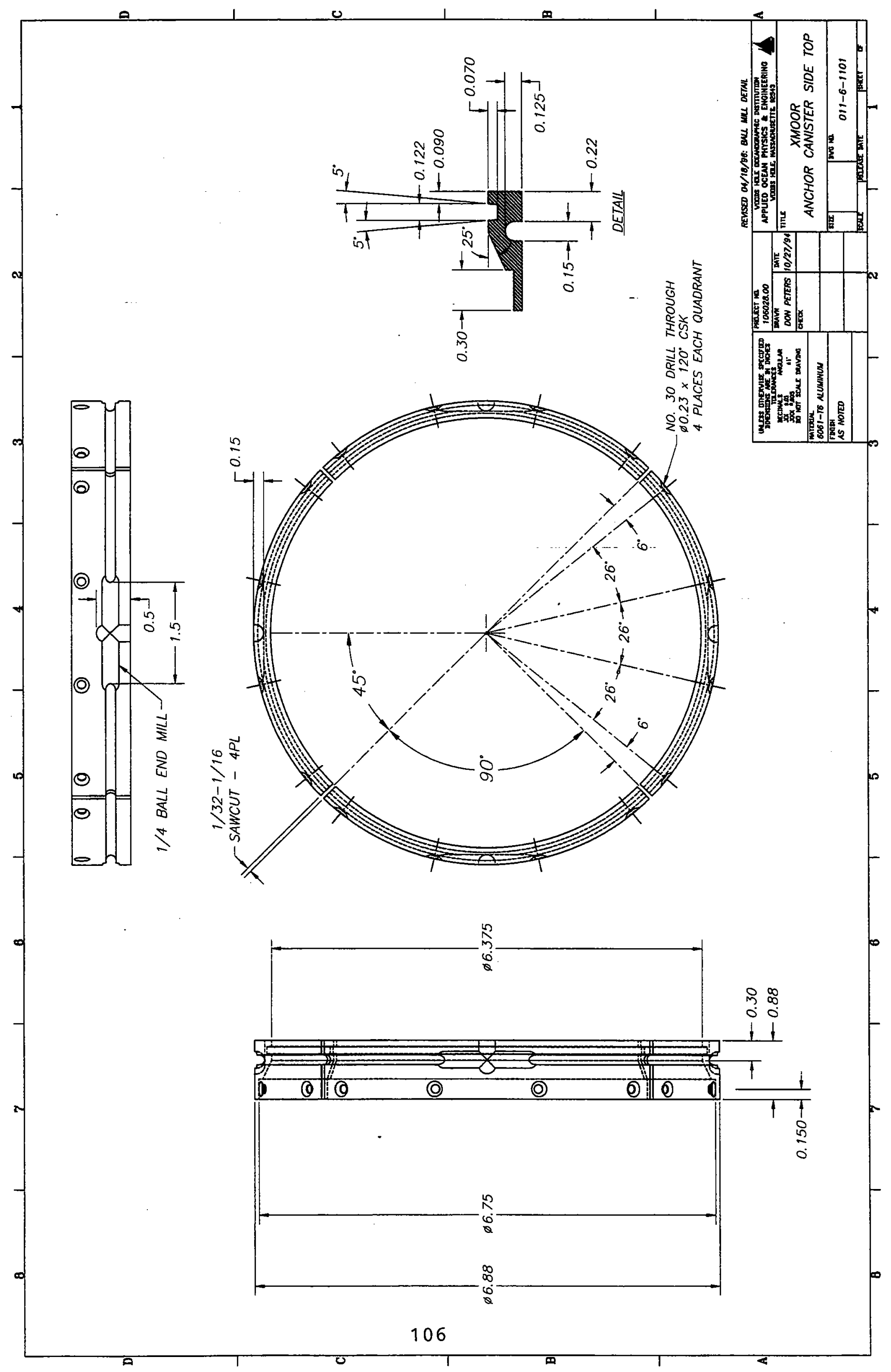




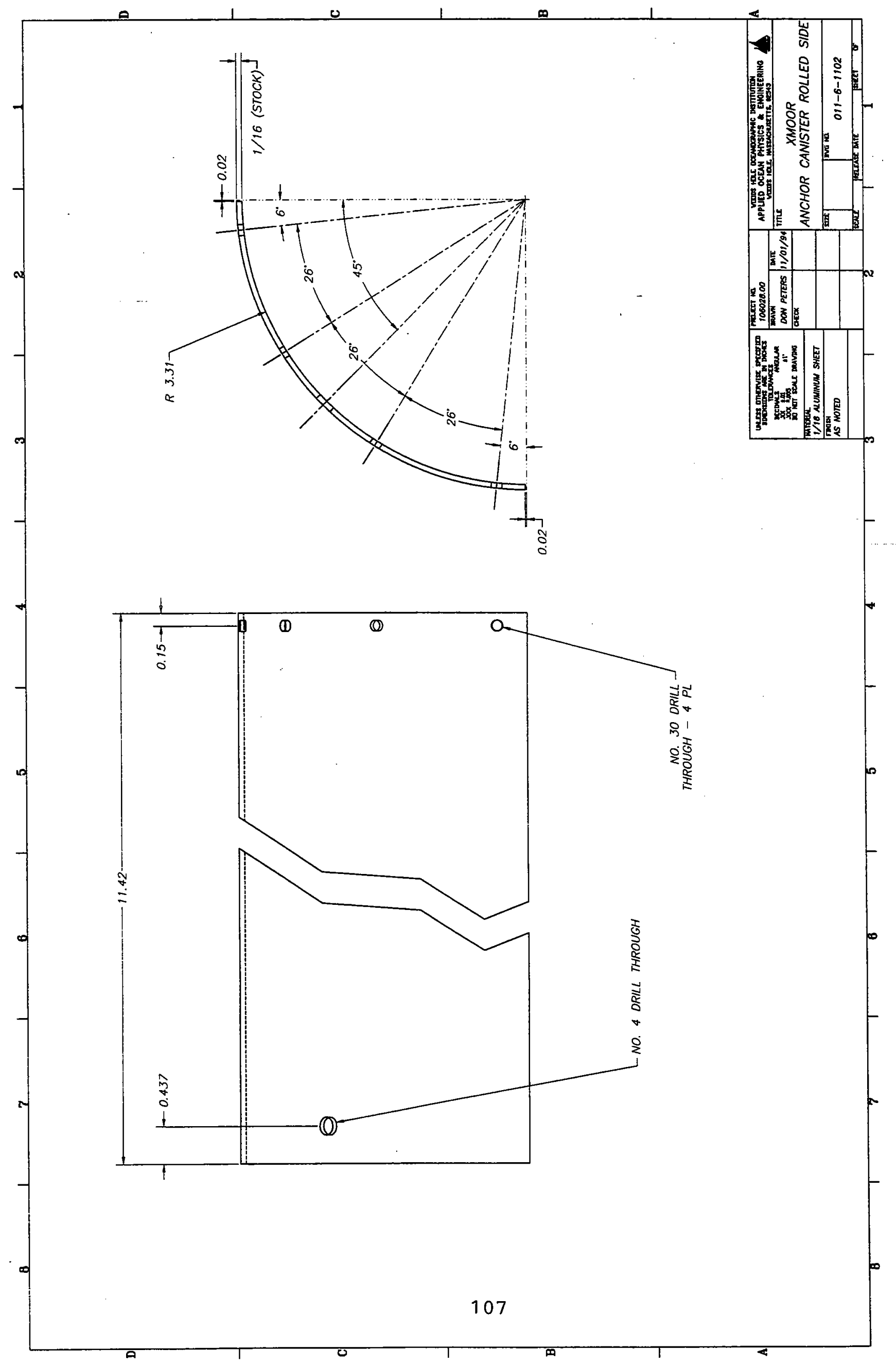




\subsection{Selected Model Runs}

XMOOR response to steady horizontal currents was examined using the NOYFB mooring program described in [7]. This program computes the shape of the mooring based on mooring tension and drag of each of the mooring elements. It was designed for use with subsurface moorings but was implemented for XMOOR by iteratively varying the effective buoyancy of the surface float to constrain it to the surface. The mooring line tension then balanced the drag forces and the mooring shape was determined. Wave forcing is not considered. The analysis was performed for four cases ranging from typical (Case 1) to moderate (Case 2) to extreme (Case 3 and Case 4). Figure 6.2-1 shows the mooring configuration used in each case for reference.

Case 1: Typical conditions - $50 \mathrm{~m}$ of water, current at the surface is $50 \mathrm{~cm} / \mathrm{sec}$ decreasing linearly to $25 \mathrm{~cm} / \mathrm{sec}$ at the bottom.

\section{Mooring Statistics - Summary - Case 1}

\begin{tabular}{|c|r|r|r|r|r|r|r|r|}
\hline Comp & $\begin{array}{l}\text { Length } \\
(\mathrm{m})\end{array}$ & $\begin{array}{l}\text { Weight } \\
(\mathrm{lbs})\end{array}$ & $\begin{array}{l}\text { Depth } \\
(\mathrm{m})\end{array}$ & $\begin{array}{l}\text { Incline } \\
(\mathrm{deg})\end{array}$ & $\begin{array}{l}\text { Tension } \\
(\mathrm{lbs})\end{array}$ & $\begin{array}{l}\text { Excur } \\
(\mathrm{m})\end{array}$ & $\begin{array}{l}\text { Drag } \\
(\mathrm{lbs})\end{array}$ & $\begin{array}{l}\text { Backup } \\
(\mathrm{lbs})\end{array}$ \\
\hline 1 & .3 & 200.0 & 0 & 12.4 & 29.1 & 42.6 & 6.2 & -42.5 \\
\hline 2 & .5 & .0 & .7 & 17.8 & 29.5 & 42.5 & 8.9 & -42.5 \\
\hline 3 & 30.0 & -.3 & 28.0 & 27.9 & 29.2 & 30.2 & 14.0 & -42.2 \\
\hline 4 & .2 & -2.0 & 28.2 & 30.3 & 27.7 & 30.1 & 14.2 & -40.2 \\
\hline 5 & 30.0 & -.3 & 53.1 & 35.9 & 27.4 & 13.4 & 16.8 & -39.9 \\
\hline 6 & .4 & -5.0 & 53.4 & 44.3 & 24.6 & 13.1 & 17.3 & -34.9 \\
\hline 7 & 15.0 & -34.9 & 50.0 & & 24.5 & .0 & 16.7 & .0 \\
\hline
\end{tabular}




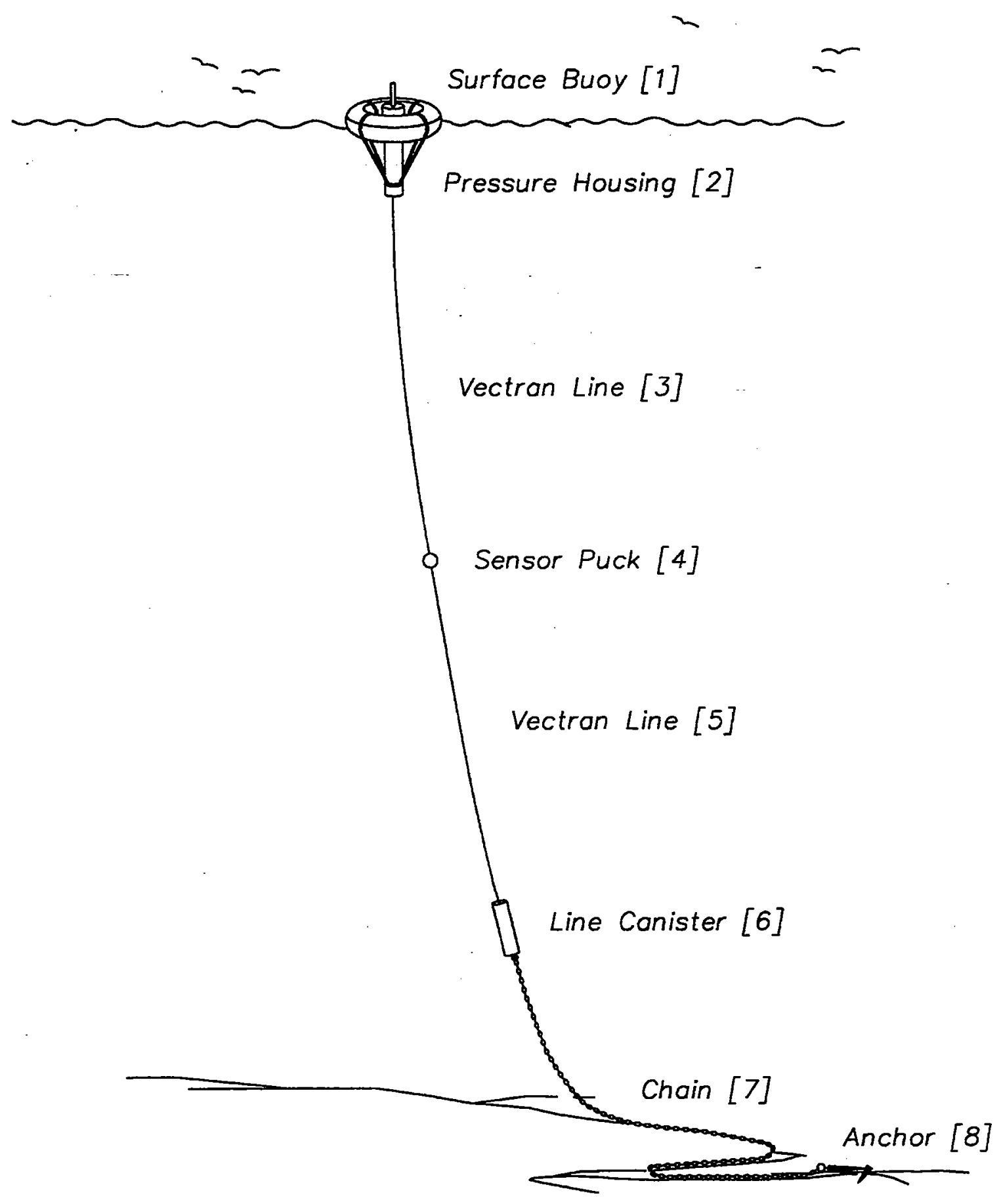

Figure 6-2-1: XMOOR mooring configuration used in the model runs 
Case 2: Moderate conditions: $100 \mathrm{~m}$ of water, current at the surface is $100 \mathrm{~cm} / \mathrm{sec}$ decreasing linearly to $50 \mathrm{~cm} / \mathrm{sec}$ at the bottom.

Mooring Statistics - Summary - Case 2

\begin{tabular}{|c|r|r|r|r|r|r|r|r|}
\hline Comp & $\begin{array}{l}\text { Length } \\
(\mathrm{m})\end{array}$ & $\begin{array}{l}\text { Weight } \\
(\mathrm{lbs})\end{array}$ & $\begin{array}{l}\text { Depth } \\
(\mathrm{m})\end{array}$ & $\begin{array}{l}\text { Incline } \\
(\mathrm{deg})\end{array}$ & $\begin{array}{l}\text { Tension } \\
(\mathrm{lbs})\end{array}$ & $\begin{array}{l}\text { Excur } \\
(\mathrm{m})\end{array}$ & $\begin{array}{l}\text { Drag } \\
(\mathrm{lbs})\end{array}$ & $\begin{array}{l}\text { Backup } \\
(\mathrm{lbs})\end{array}$ \\
\hline 1 & .3 & 200.0 & 0 & 15.1 & 93.9 & 96.0 & 24.2 & -43.2 \\
\hline 2 & .5 & .0 & .7 & 21.3 & 97.0 & 95.8 & 34.4 & -43.2 \\
\hline 3 & 30.0 & -.3 & 27.0 & 33.5 & 96.5 & 81.4 & 54.8 & -42.9 \\
\hline 4 & .2 & -2.0 & 27.1 & 34.8 & 95.9 & 81.3 & 55.8 & -40.9 \\
\hline 5 & 95.0 & -.9 & 94.2 & 50.8 & 95.5 & 14.2 & 81.9 & -39.9 \\
\hline 6 & .4 & -5.0 & 94.5 & 53.8 & 97.3 & 13.9 & 83.0 & -34.9 \\
\hline 7 & 15.0 & -34.9 & 100.0 & 75.8 & 82.4 & .0 & 85.6 & .0 \\
\hline
\end{tabular}

Case 3: Extreme conditions: $50 \mathrm{~m}$ of water, current is $150 \mathrm{~cm} / \mathrm{sec}$ top to bottom.

\section{Mooring Statistics - Summary - Case 3}

\begin{tabular}{|c|r|r|r|r|r|r|r|r|}
\hline Comp & $\begin{array}{l}\text { Length } \\
(\mathrm{m})\end{array}$ & $\begin{array}{l}\text { Weight } \\
(\mathrm{lbs})\end{array}$ & $\begin{array}{l}\text { Depth } \\
(\mathrm{m})\end{array}$ & $\begin{array}{l}\text { Incline } \\
(\mathrm{deg})\end{array}$ & $\begin{array}{l}\text { Tension } \\
(\mathrm{lbs})\end{array}$ & $\begin{array}{l}\text { Excur } \\
(\mathrm{m})\end{array}$ & $\begin{array}{l}\text { Drag } \\
(\mathrm{lbs})\end{array}$ & $\begin{array}{l}\text { Backup } \\
(\mathrm{lbs})\end{array}$ \\
\hline 1 & .3 & 200.0 & 0 & 20.6 & 152.7 & 55.8 & 51.0 & -42.5 \\
\hline 2 & .5 & .0 & .9 & 28.3 & 165.3 & 55.6 & 71.5 & -42.5 \\
\hline 3 & 30.0 & -.3 & 24.7 & 43.0 & 164.6 & 37.4 & 113.7 & -42.2 \\
\hline 4 & .2 & -2.0 & 24.9 & 44.3 & 168.0 & 37.3 & 115.9 & -40.2 \\
\hline 5 & 30.0 & -.3 & 44.1 & 53.7 & 168.1 & 14.2 & 143.4 & -39.9 \\
\hline 6 & .4 & -5.0 & 44.4 & 57.5 & 204.7 & 13.9 & 150.2 & -34.9 \\
\hline 7 & 15.0 & -34.9 & 50.0 & 72.6 & 191.3 & .0 & 170.4 & .0 \\
\hline
\end{tabular}


Case 4: Extreme conditions: $100 \mathrm{~m}$ of water, currents at the surface are 150 $\mathrm{cm} / \mathrm{sec}$ decreasing linearly to $100 \mathrm{~cm} / \mathrm{sec}$ at the bottom

\begin{tabular}{|c|c|c|c|c|c|c|c|c|}
\hline \multicolumn{9}{|c|}{ Mooring Statistics - Summary - Case 4} \\
\hline Comp & $\begin{array}{l}\text { Length } \\
(\mathrm{m})\end{array}$ & $\begin{array}{l}\text { Weight } \\
\text { (lbs) }\end{array}$ & $\begin{array}{l}\text { Depth } \\
(\mathrm{m})\end{array}$ & $\begin{array}{l}\text { Incline } \\
\text { (deg) }\end{array}$ & $\begin{array}{l}\text { Tension } \\
\text { (lbs) }\end{array}$ & $\begin{array}{l}\text { Excur } \\
(\mathrm{m})\end{array}$ & $\begin{array}{l}\text { Drag } \\
\text { (lbs) }\end{array}$ & $\begin{array}{l}\text { Backup } \\
\text { (lbs) }\end{array}$ \\
\hline 1 & .3 & 200.0 & 0 & .19 .9 & 204.0 & 99.2 & 66.5 & -42.6 \\
\hline 2 & .5 & .0 & .6 & 26.9 & 217.8 & 98.9 & 91.5 & -42.7 \\
\hline 3 & 30.0 & -.3 & 25.7 & 37.6 & 217.3 & 82.2 & 131.6 & -42.5 \\
\hline 4 & .2 & -2.0 & 25.9 & 38.6 & 220.1 & 82.1 & 134.5 & -40.6 \\
\hline 5 & 95.0 & -.9 & 91.6 & 50.2 & 220.0 & 13.2 & 178.2 & -39.8 \\
\hline 6 & .4 & -5.0 & 92.0 & 51.7 & 223.7 & 12.8 & 180.1 & -34.8 \\
\hline 7 & 15.0 & -34.9 & 100.0 & 60.9 & 204.4 & .0 & 185.5 & .0 \\
\hline
\end{tabular}




\subsection{Test Reports}

1. Mooring line test report from Tension Member Technology, April 11, 1996.

2. Anchor testing memo, October 13, 1994.

3. Vineyard Sound deployment memo, October 13, 1994.

4. XMOOR deployments to date memo, November 4, 1996

5. Surface buoy test documentation from Lamcotec, Inc. 


\section{Tension Member Technology}

5721 Research Drive

Huntington Beach, CA 92649-1616

Tel: 714-898-5641 Fax: 714-893-1925

\section{Shipping Document}

Date: April 11, 1996

Ship To: Woods Hole Oceanographic Institute

Attn: Receiving Department

266 Woods Hole Road

Woods Hole, MA 02543

Telephone: $508-457-2000$

Order Number: M100237

TMT Project: 2144
Ship Via:
UPS
Federal Express
Motor Freight

_x_U.S. Mail

Prepaid

Collect

Air Freight

Value: $\$ 2,000$

\begin{tabular}{|l|l|l|l|l|}
\hline Item & Quantity & \multicolumn{1}{|c|}{ Description } & Dimensions & Weight \\
\hline & & & & \\
\hline 0001 & 1 each & Test Report on: & & \\
\hline & & Cyclic-Tension Fatigue and Breaking Strength & & \\
\hline & & Tests as Outlined in WHOI Fax of 01/19/96 & & \\
\hline & & & & \\
\hline & & & & \\
\hline & & & & \\
\hline & & & & \\
\hline & & & & \\
\hline & & & & \\
\hline & & & & \\
\hline & & & & \\
\hline & & & & \\
\hline & & & & \\
\hline & & & & \\
\hline & & & & \\
\hline
\end{tabular}

Shipped By: Philip T. Gibson

Received By:

Date: 
11 April 1996

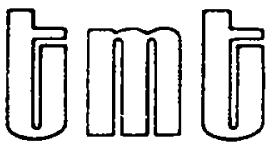

Mr. Don Peters

Advanced Engineering Laboratory - Smith 310

Woods Hole Oceanographic Institution

Woods Hole, MA 02548

Dear Don,

Subject: $\quad$ Tests of Buoy Mooring Line

Purchase Order M100237

TMT Report FR-2144

Please find enclosed a summary of the procedures and data collected during cyclic-tension and breaking strength tests of your five Vectran $\otimes$-strengthened electromechanical cable specimens. The tests were conducted in accordance with your testing description dated 19 January 1996.

The tests were conducted in a horizontal load frame equipped with a hydraulic cylinder and tension monitoring strain gage load cell. Cable elongation was measured on the first and last cycle of each sequence using an extensometer with a 33-inch gage-length. The extensometer was attached to the midsection of each specimen between the terminations. Displacement of the central conductor package relative to the termination grips was measured prior to and following each cyclic-straight-tension (CST) test.

The central conductor of each specimen was cut to a length approximately that of the mechanical eye-to-eye length so that any changes in resistance in the tested length would be more apparent. Conductor DC Resistance was also measured prior to and following each CST test and was continuously monitored throughout the cycling as well as during the final pull to break.

The CST test involved repeated loading and unloading of each cable specimen between two tension limits for a number of cycles. The tension limits and numbers of cycles for each specimen are summarized below in Table 1. A different cycling rate was used for each specimen to expedite those specimens having large numbers of test cycles. Following each CST test, the specimens were pulled to break while measuring elongation vs tension. Electrical continuity was also measured up to the point of break.

Each specimen retained a breaking strength within the specified range of 1,200 to 1,800 pounds. All of the specimens showed less than 1 percent change of DC resistance during the cycling (see Table 2) and all conductors remained continuous during the final pull to break until the point of cable mechanical failure. With the exception of Specimen A3 which suffered during a malfunction in the extensometer and tension control system, all five specimens had approximately $5 \%$ total elongation at break. The only anomalous behavior during testing occurred during the pull to break of Specimens A2 and A3. At slightly more than 1,000-pounds tension, they both began to suffer partial strength member breakage up to the point of 
complete failure. There is no obvious explanation why these two specimens, but none of the others, suffered from this problem.

TABLE 1. SUMMARY OF TEST PARAMETERS AND RESULTS

\begin{tabular}{|c|c|c|c|c|}
\hline $\begin{array}{c}\text { Specimen } \\
\text { Number }\end{array}$ & $\begin{array}{c}\text { Load Range, } \\
\text { pounds }\end{array}$ & Load Cycles & $\begin{array}{c}\text { Elongation at } \\
\text { Failure }\end{array}$ & $\begin{array}{c}\text { Breaking Load, } \\
\text { pounds }\end{array}$ \\
\hline \hline A1 & 10 to 1,000 & 250 & 4.93 & 1,740 \\
\hline A2 & 10 to 500 & 1,000 & 5.10 & 1,630 \\
\hline A3 & 10 to 300 & 3,000 & $3.79^{*}$ & 1,455 \\
\hline A4 & 10 to 200 & 10,000 & 5.05 & 1,630 \\
\hline A5 & 10 to 50 & 100,000 & 4.52 & 1,610 \\
\hline
\end{tabular}

*- Constructional Stretch lost due to extensometer failure.

TABLE 2. SUMMARY OF CONDUCTOR RESISTANCE MEASUREMENTS

\begin{tabular}{|c|c|c|c|}
\hline \multirow{2}{*}{ Specimen } & \multicolumn{2}{|c|}{ Resistance, $\Omega / 1000$ Feet @ 20 ${ }^{\circ} \mathrm{C}$} & \multirow{2}{*}{ \% Change } \\
\cline { 2 - 3 } & Prior & Following & -0.8 \\
\hline A1 & 25.2 & 25.0 & 0.4 \\
\hline A2 & 25.1 & 25.2 & -0.8 \\
\hline A3 & 25.4 & 25.2 & 0.8 \\
\hline A4 & 25.3 & 25.5 & 0.4 \\
\hline A5 & 25.5 & 25.6 & \\
\hline
\end{tabular}

The pages which follow are the load-elongation curves recorded for each of the specimens during each CST test and final pull to break.

If there are any questions regarding the testing or data, please feel free to call.

Sincerely,

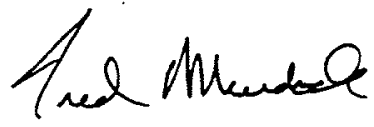

Frederick Murdock

Project Engineer 
1250 Tension (16f.)

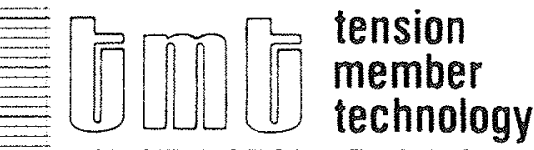

HUNTINGTON BEACH, CA

FIGURE \#I

SPECIMEN $2144-A 1$

DATE /April 1996

Elangation v5. Iexsion

$\stackrel{0}{10}$

750

* fyetes 1,10 and 250

* No Grap Stppage

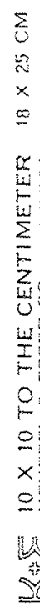

500
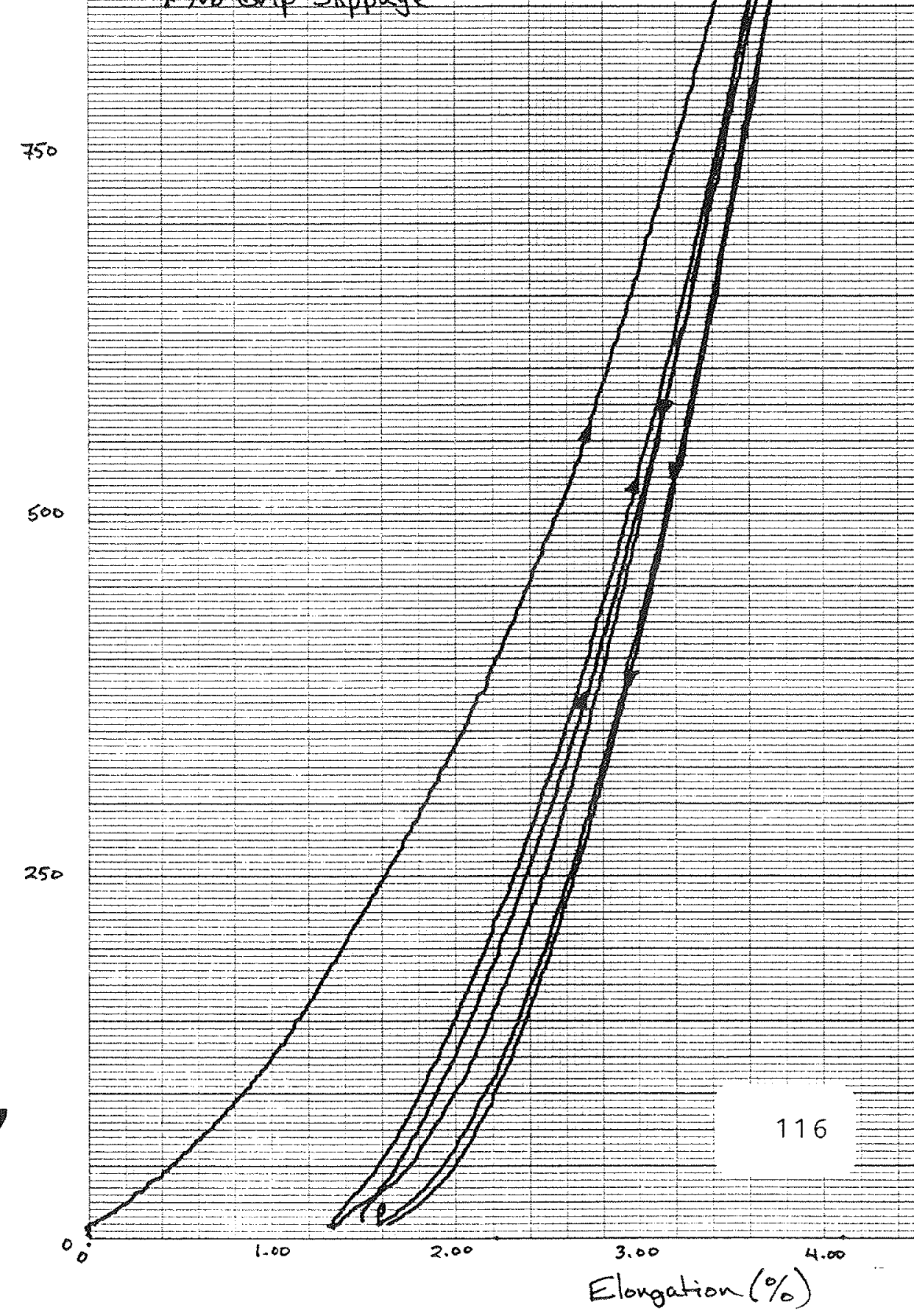


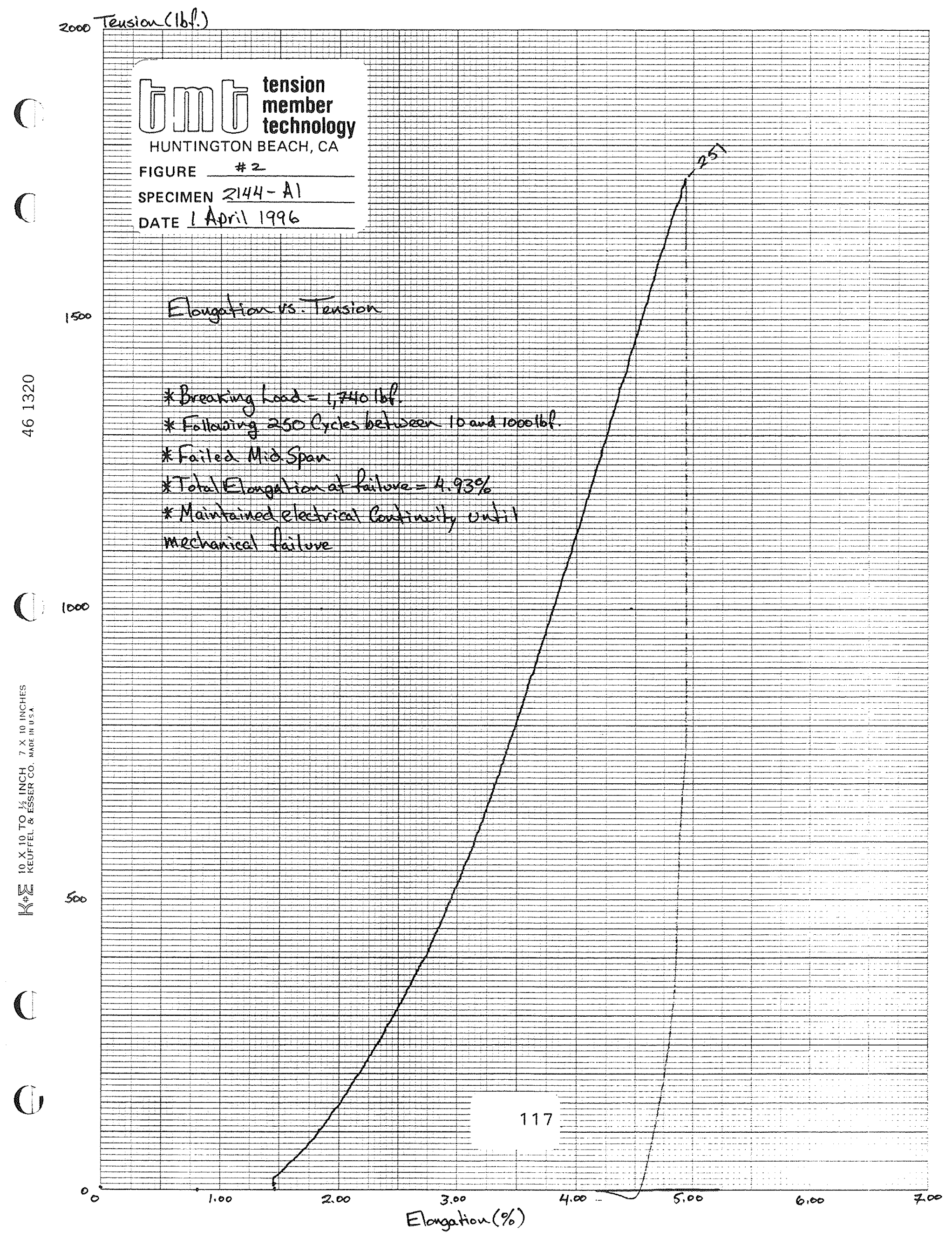


1250 Tension (16f.)

Atongation Vs. Texsion

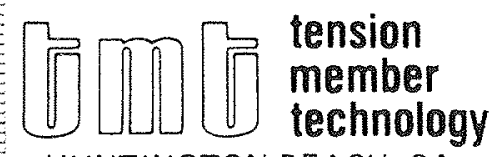

* fuctes $\tan 0$ 1000 to 50010 t. HUNTINGTON BEACH, CA

FIGURE

* No-Gap Stppage

SPECIMEN 2144 - A2

DATE 3 April 1996

0
$\stackrel{-10}{10}$
0
0
8

$\sum$

1000

浆

250

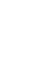
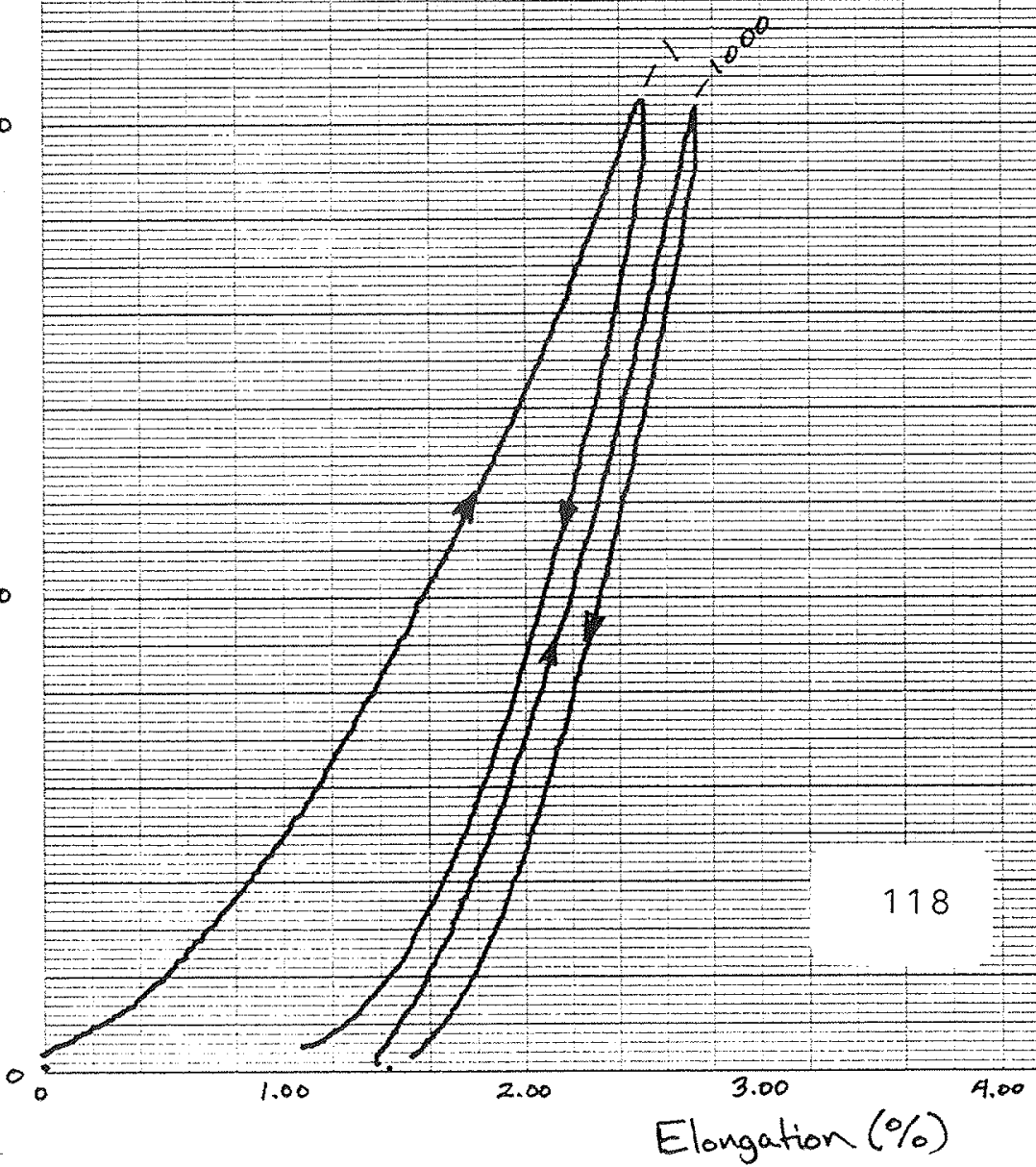


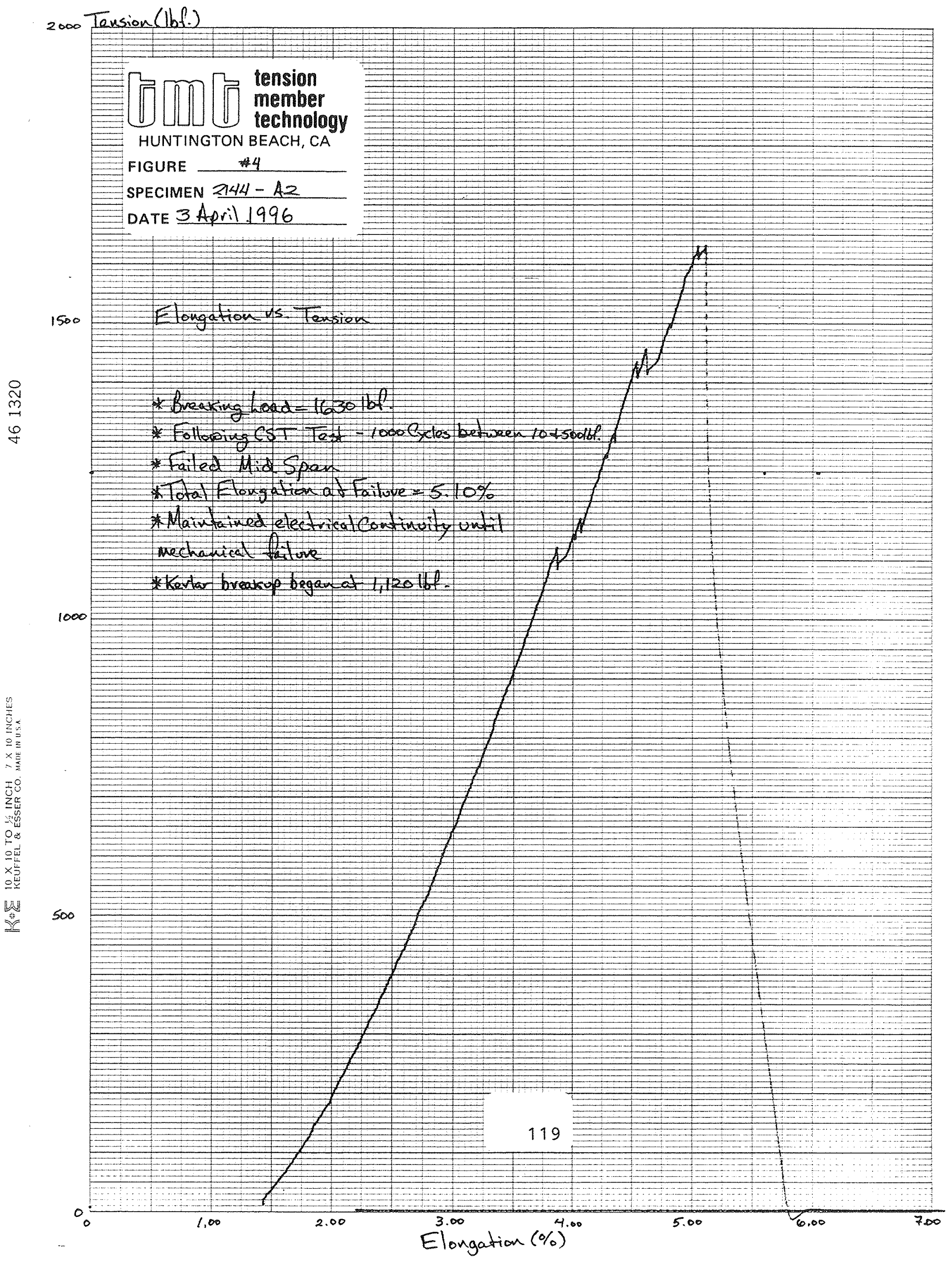


1250 Tension (16f.)

Eloogation 15, Tanstion

$\overline{0}\left[\pi\left[\begin{array}{l}\text { tension } \\ \text { member } \\ \text { technology }\end{array}\right.\right.$ HUNTINGT technology

* Aydes tand 3000 to 300 llt

FIGURE \#S

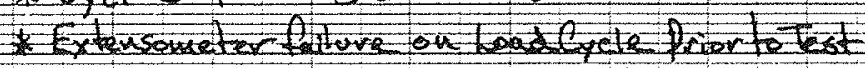

SPECIMEN Z144-A3

- whitateoustracticasals fretch lost

1000

NoGup Stippare

750

500

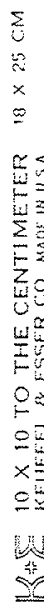




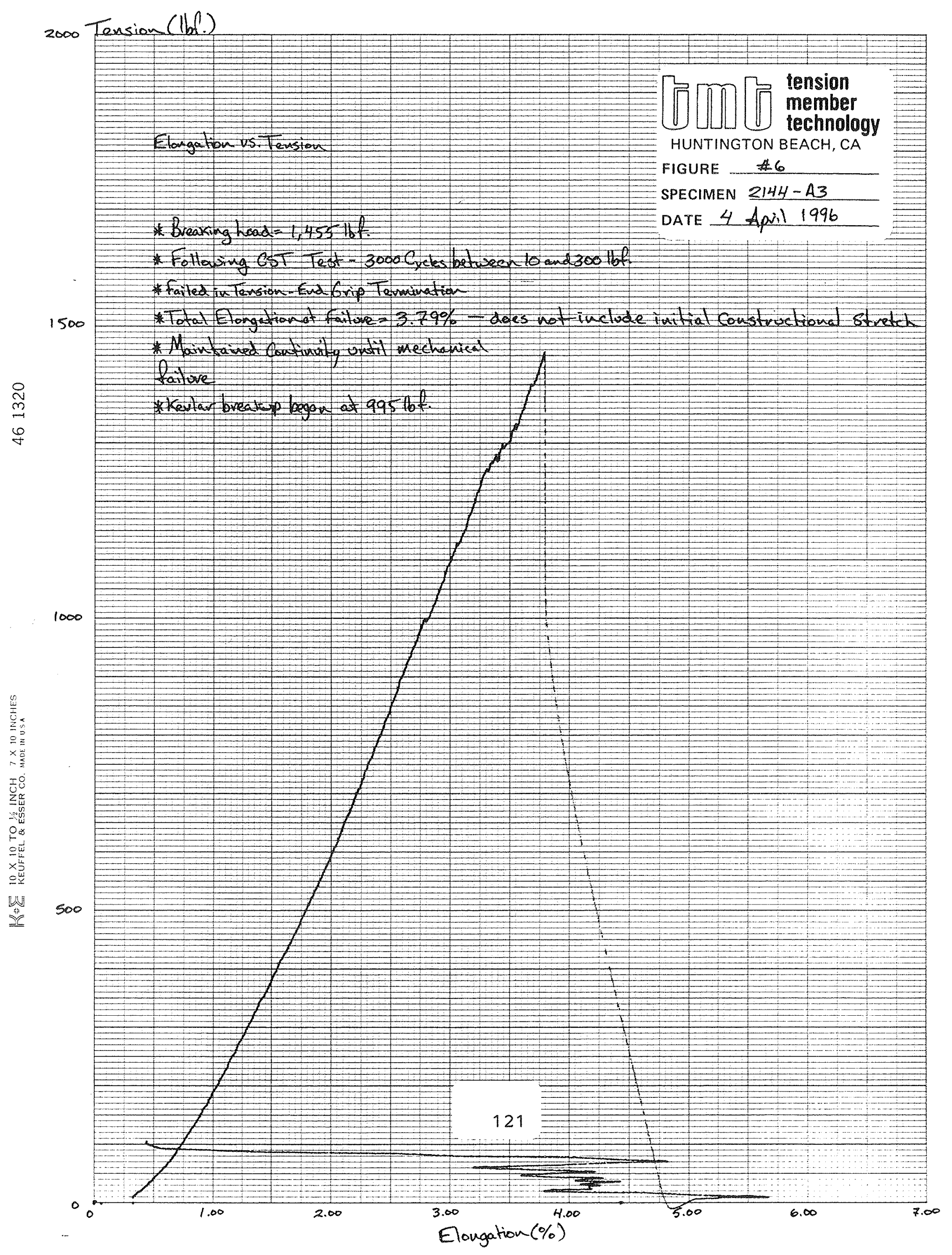


1250 Teusion (1bf.)

Elongation. vs. Texsion

* Gycles 1,2 and 10,000

*No-Gripstippage

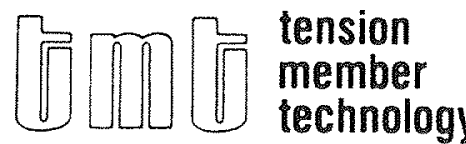

HUNTINGTON BEACH, CA

FIGURE \#7

SPECIMEN $21144-A 4$

DATE 9 April 1996

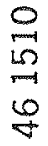

1000

250

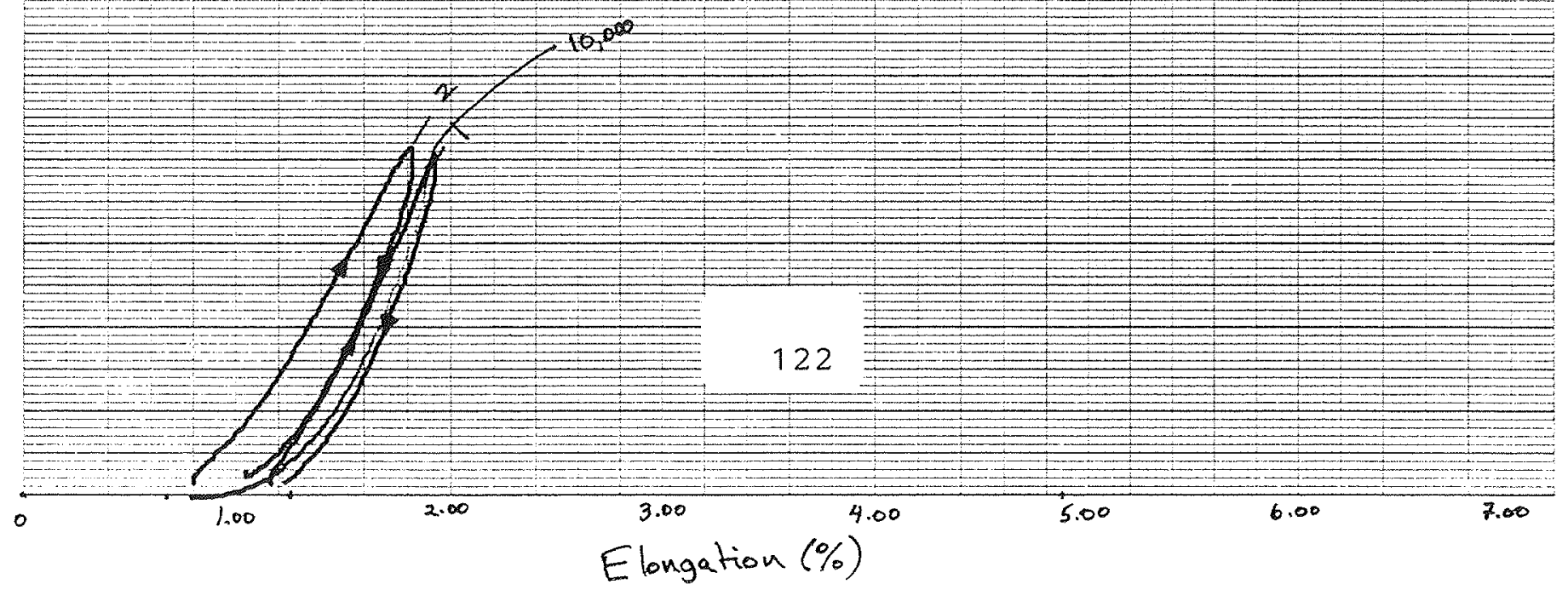


2000 Tension (1bf)

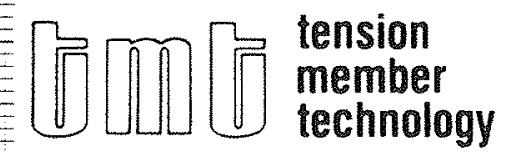

HUNTINGTON BEACH, CA

FIGURE 8

SPECIMEN 2144-A4

DATE 9 April 1996

Elangation VS. Tension

* Broaxing hoed - 1,630 bt

* Follawing lack to $1,388 \mathrm{At}$ -

Hetratic Gytuder botomed out

* Following 10,000 Cycles between 10 and zoo ibl.

- Faitedat Toe on termination

* Maintained electrieal Continuty untel

wrechanical fattove

1000

Total Elougation at faiture $=5.05 \%$

500

0.

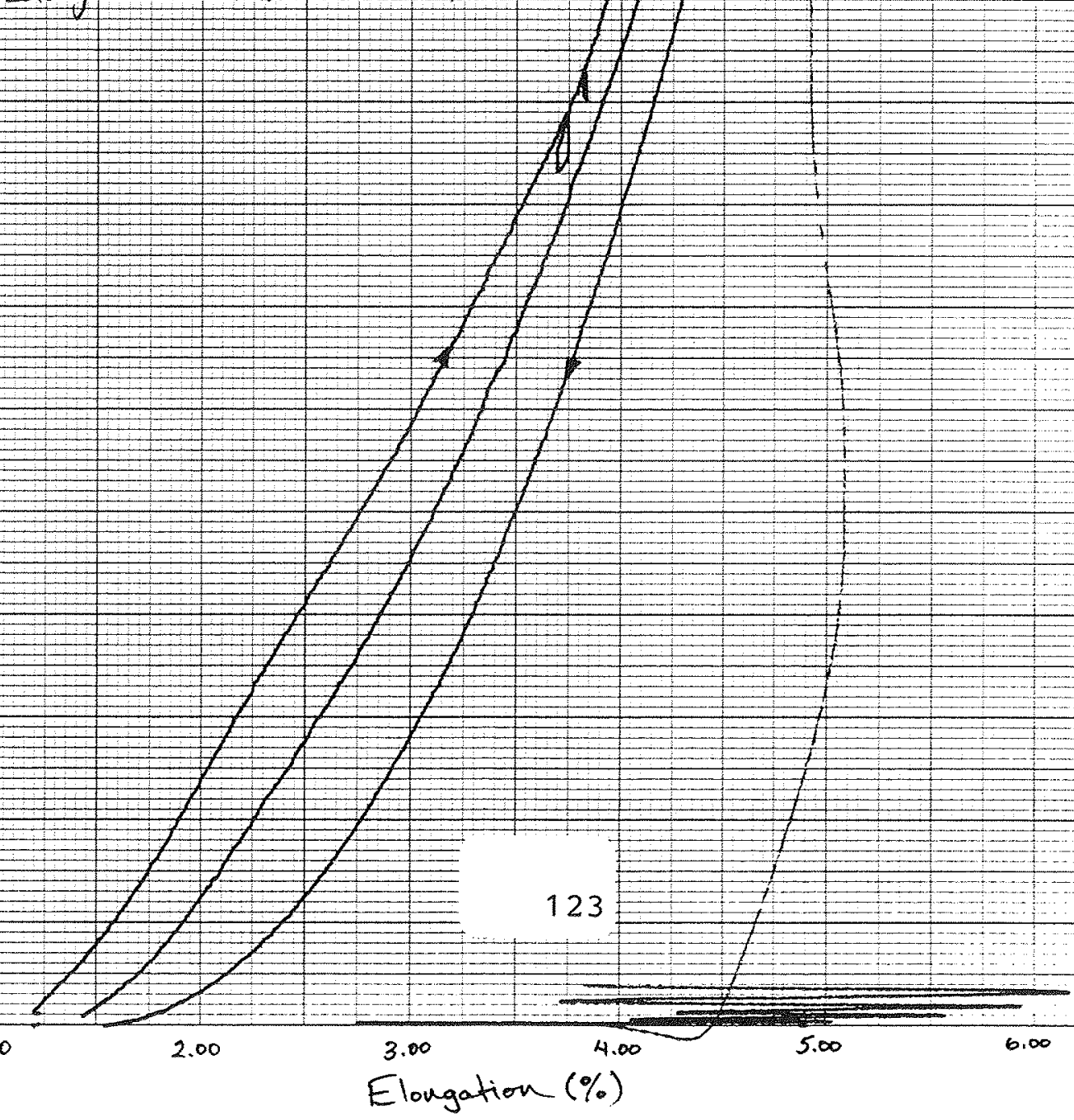




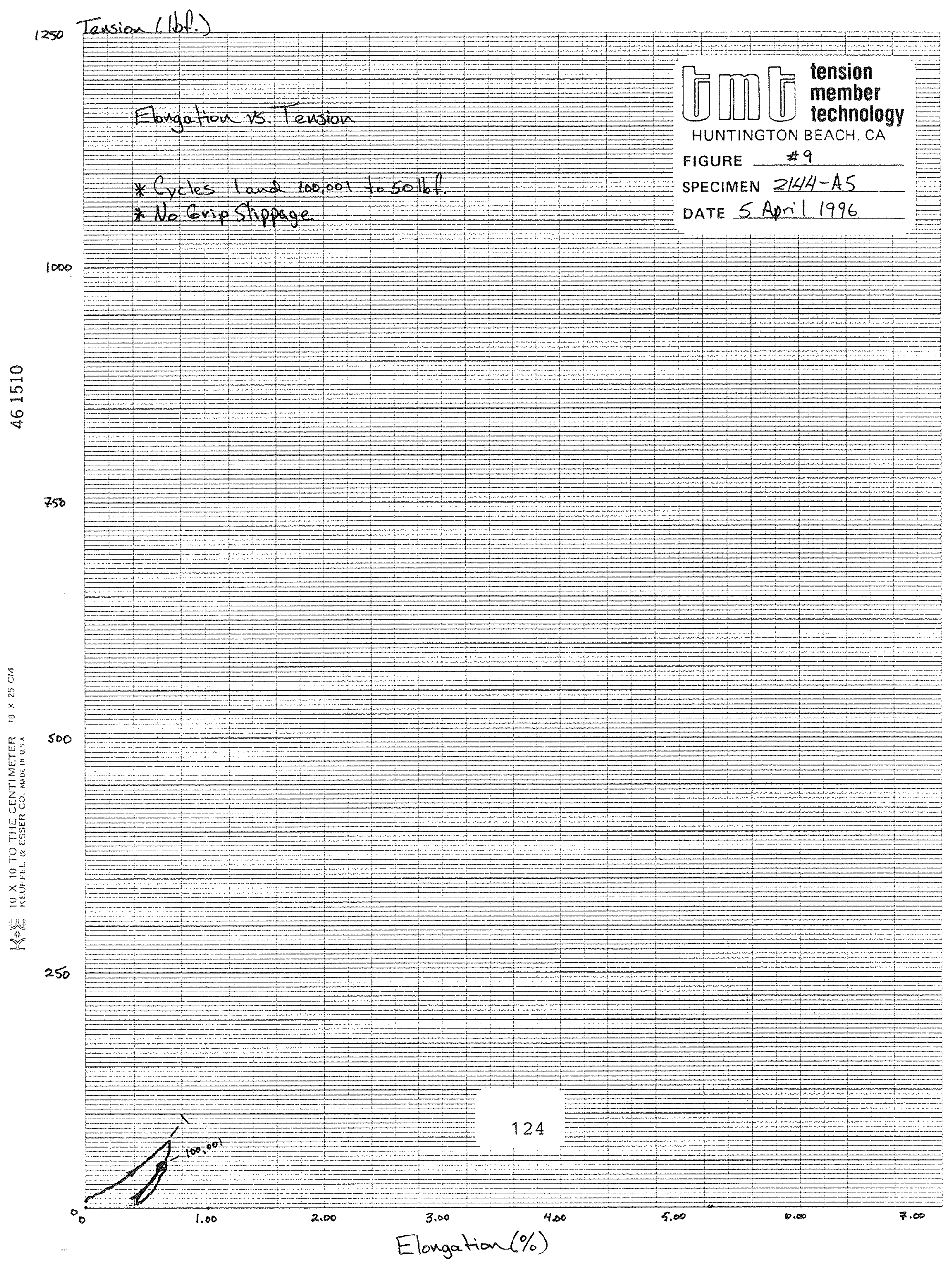




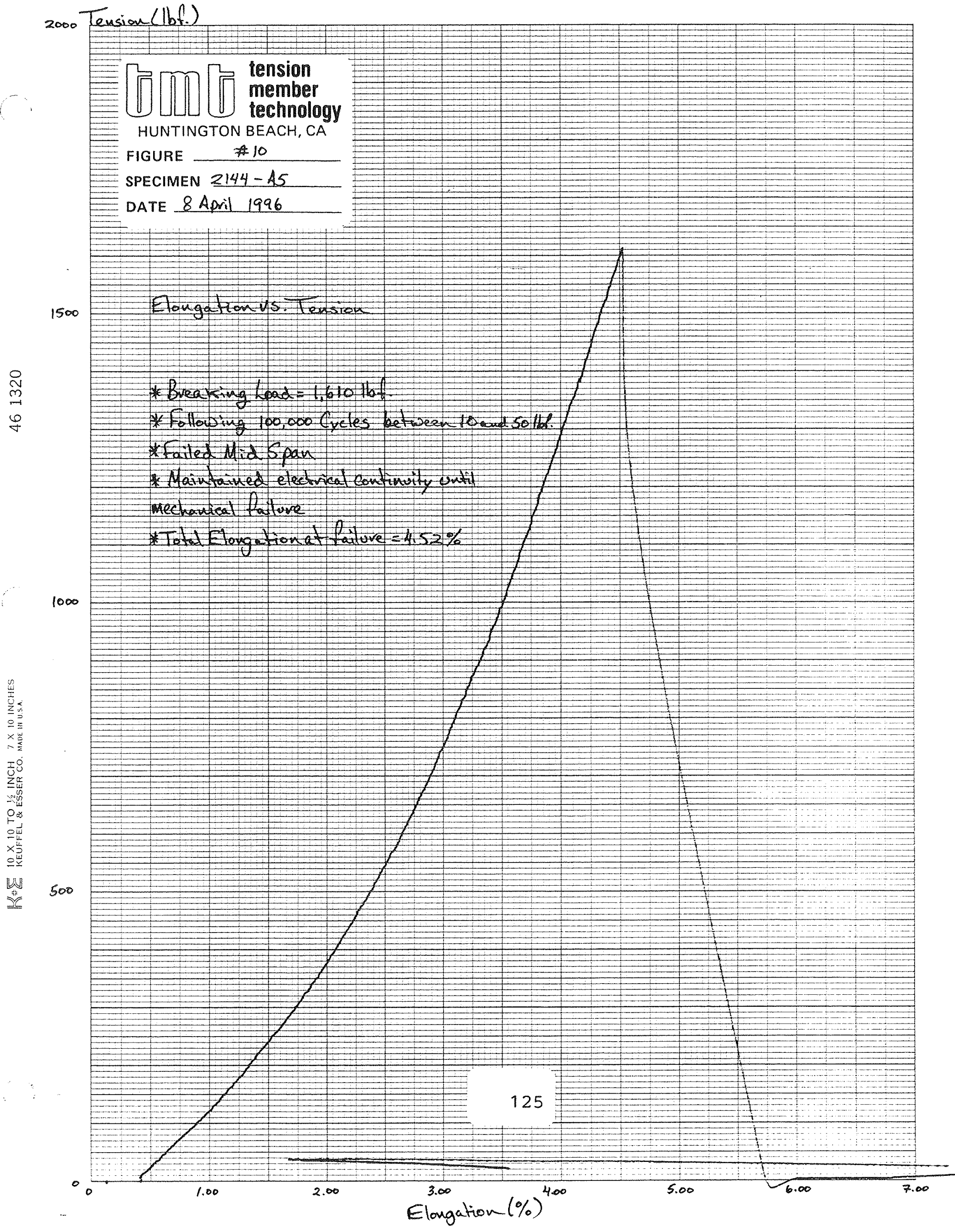




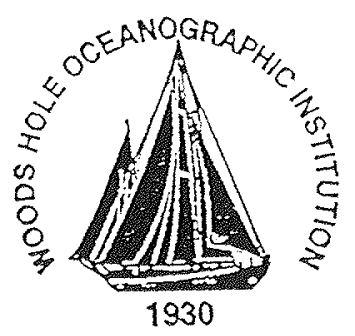

ADVANCED ENGINEERING LABORATORY

MEMO

DATE: $\quad$ 10/13/94

TO: $\quad$ XMOOR Files

FROM: Don Peters

SUBJECT: Anchor Testing

FILE: $\quad$ xm090294.mem

On 08/26/94, XMOOR folding anchor embedment observations were made, and on $09 / 02 / 94$, embedded anchor force measurements were obtained. This memo documents these tests.

The XMOOR anchor was tested in fine soft sand and shallow water, on Seawall Beach, Maine. The observation tests included the following:

- Embedment observations (see photographs). Anchor was started out folded, on its side. It was pulled and observed to open and embed. Mean distance pulled to embed was about $4 \mathrm{ft}$. One fluke opened followed by a second fluke, and both embedded until the third fluke lay flush on the bottom. The shank was then parallel with the bottom about 2 in. down. About $2 \mathrm{ft}$. of chain was embedded as well. This test was repeated numerous times without any failures to embed.

Re-embedment observation. Anchor was started out embedded, and was then pulled from the "wrong" direction. It was observed pulling out and turning over, and was pulled until it re-embedded. This was to simulate a situation where the mooring experiences a tide reversal. In several instances the "up" fluke failed to open immediately due to grit in the joints. This impaired re-embedment. A modified joint design with increased clearances is expected to solve this problem. In general, however, the anchor turned over and re-embedded normally. Turning over took about $3 \mathrm{ft}$. and re-embedment took about $4 \mathrm{ft}$. 
Observation of erosion around embedded anchor. The anchor was embedded in the downstream direction on the bottom of a tidal river with water depth of 3 $\mathrm{ft}$. and current speed of about 1.5 knot. This test was tried with the "up" fluke both folded and extended. There was no discernable erosion in the vicinity of the anchor during a 20 minute period.

- Chain packing and pullout (see photographs). The anchor and $16 \mathrm{~m}$ of $1 / 4^{\prime \prime}$ chain was packed in a $6.75^{\prime \prime}$ i.d. tube. The tube was pulled off the package from above, and the chain pulled from the side until all of it was streched out. This was repeated five times with no tangling problems. It should be noted that in packing, the chain must be flaked in carefully and not twisted around the anchor shank.

Force measurements involved the following:

Static pull. A $200 \mathrm{lb}$. spring scale was placed between the XMOOR anchor and a $5 \mathrm{~kg}$ Bruce anchor. Both anchors were embedded and slack was taken up. The tension was then increased to $200 \mathrm{lb}$. Since the spring scale had a full scale deflection of only about 8 in., a small amount of creep in either anchor resulted in a large reduction of tension in the system. The system repeatedly crept down to approximately $70 \mathrm{lb}$. static force (no creep).

Impulse pull. The Eruce anchor was disconnected and the XMOOR anchor pulled directly with the scale. Repeated short pulls of $200 \mathrm{lb}$. produced no anchor pullout. More sustained pulls of $150 \mathrm{lb}$. resulted in steady anchor creep of approximately $1 / 2 \mathrm{~cm} / \mathrm{sec}$.

- Bruce vs. XMOOR. In this test the two anchors, about $100 \mathrm{ft}$. apart, were connected with a taut line. The scale was connected in between the two anchors and a perpendicular pull was exerted. At an angle of $107^{\circ}$ between the pull line and either anchor, a scale reading of $120 \mathrm{lb}$. produced a steady creep in both anchors of about $1 \mathrm{~cm} / \mathrm{sec}$. The force on each anchor at this point was approximately $60 / \sin \left(17^{\circ}\right)$ or $205 \mathrm{lb}$.

The weights of the tested equipment were as follows:

Bruce anchor $12 \mathrm{lb}$.

XMOOR anchor $11 \mathrm{lb}$.

Chain $35 \mathrm{lb}$.

$\mathrm{DBP} / \mathrm{dbp}$

encl.

cc:

Dan Frye

Richard Arthur 

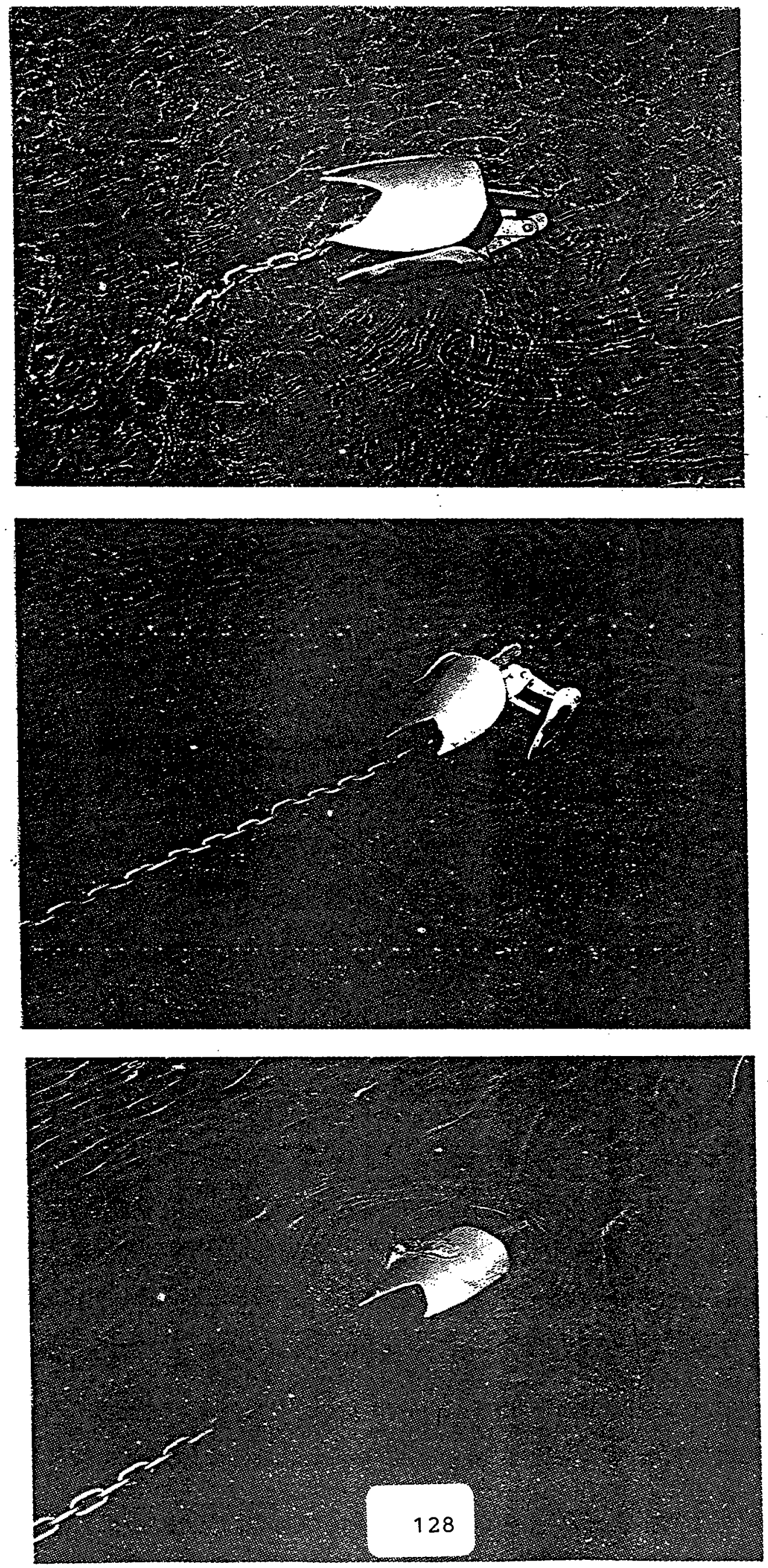

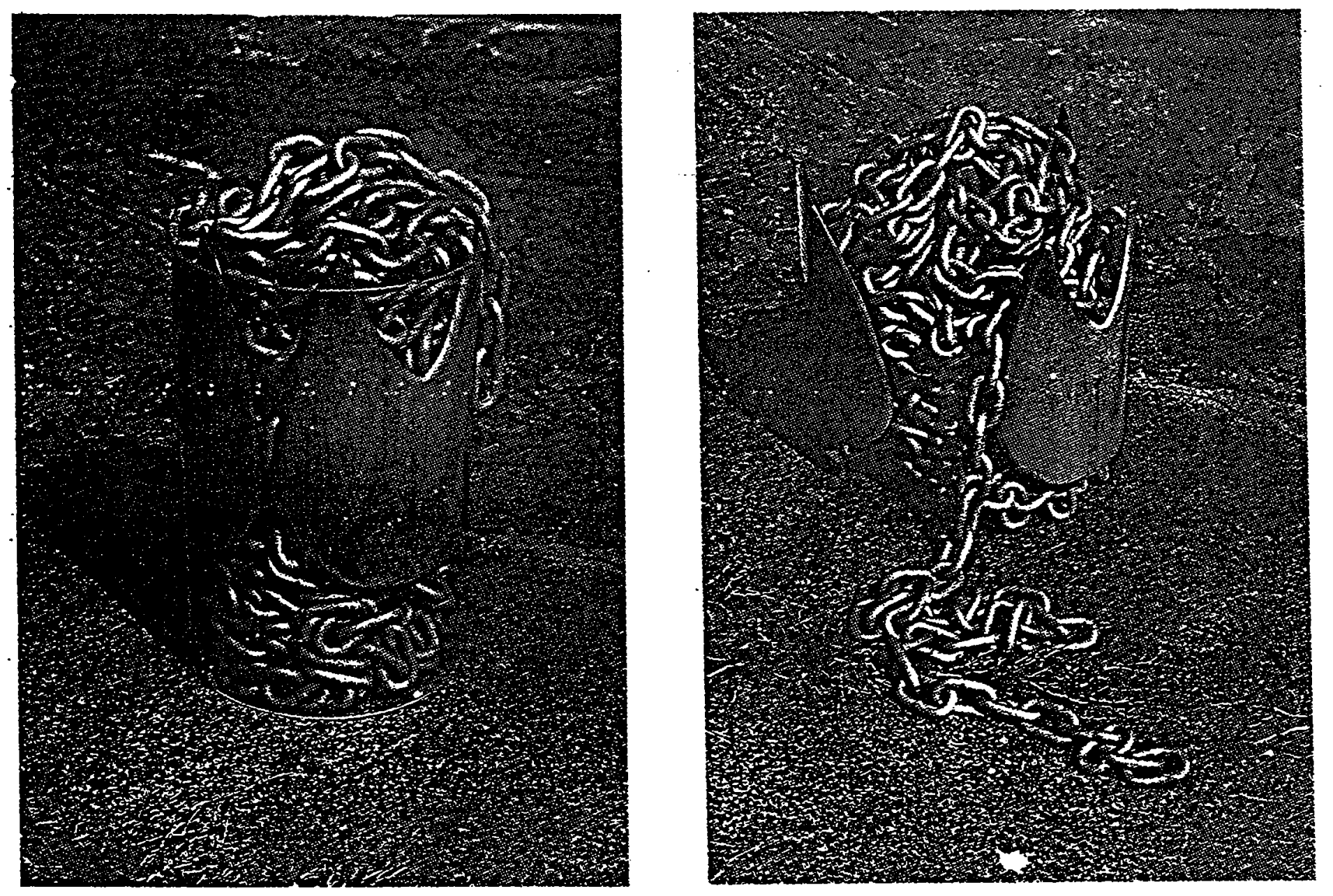


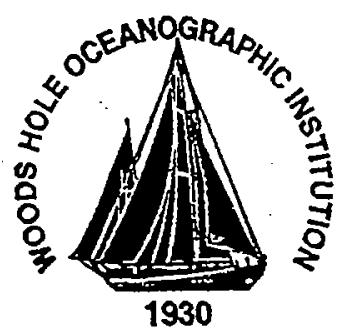

ADVANCED ENGINEERING LABORATORY

\section{MEMO}

DATE: $\quad 10 / 13 / 94$

TO: $\quad$ XMOOR Files

FROM: Don Peters

SUBJECT: Vineyard Sound Deployment 10/07/94

FILE: $\quad$ xm100794.mem

On 10/07/94, XMOOR system \#2 was deployed in Vineyard Sound, SE of WHOI, at approximately $41^{\circ}-30^{\prime} \mathrm{N}, 70^{\circ}-40^{\prime} \mathrm{W}$. Water depth at this location, given by the WHOI $19^{\prime}$ Whaler depth sounder, was $80 \mathrm{ft}$., or $24 \mathrm{~m}$. The system was deployed at approximately $1430 \mathrm{EDT}$, or about $3 \mathrm{hrs} 10 \mathrm{~min}$ after ebb begins at Pollock Rip Channel (see attached copy: Eldridge; Tidal Current Chart, Buzzards Bay, Vineyard and Nantucket Sounds). The expected current was 1 knot flowing SW. Wind was SW, approximately 12 knots. Myself, Richard Arthur, and Steve Murphy were present:

A $100 \mathrm{ft}$. preventer line was attached from the boat to the pressure housing skirt. The system was deployed to windward (SW) of the boat, which was drifting about 1/2 knot to the NE due to wind and 1 knot to the SW due to tide (net drift $1 / 2$ knot SW). The buoy separated, surfaced and inflated, at which time the boat had drifted away about $50 \mathrm{ft}$ due to wind. At this point the anchor bit in, and the boat set down on the buoy with the current. The boat was brought around to hold station with the buoy, and landmarks were sighted to verify that our position was holding.

Current was visually estimated at $1 \mathrm{knot}$ and a sponge thrown from the bow of the boat travelled the boat's $19 \mathrm{ft}$ length in 11 seconds as we held station with the buoy. Thus current speed was approximately $1.7 \mathrm{ft} / \mathrm{s}$ or 1 knot. 
Due to a damaged inflator on one gas bottle, only three of the four bottles fired upon deployment. The buoy filled adequately and the antenna deployed successfully, however. The problem with the inflator had been noticed when the buoy was being packed, and can be avoided in the future.

This was the first time that an XMOOR had been deployed using an actual line pack incorporating a thermistor string and pucks. The water depth was such that a lockup was expected at $31 \mathrm{~m}$, with the midwater puck pulling out just before lockup. Upon retrieval it was found that the puck had pulled out successfully and the $31 \mathrm{~m}$ lockup had functioned.

The system was recovered by hand by two of us. The boat was run against the current to aid in recovery. All mooring components were found to be paid out without twists or tangles. The anchor retained material from the bottom, which was muddy sand.

$\mathrm{DBP} / \mathrm{dbp}$

encl.

cc:

Dan Frye

Richard Arthur

Janice Boyd (NRL) 

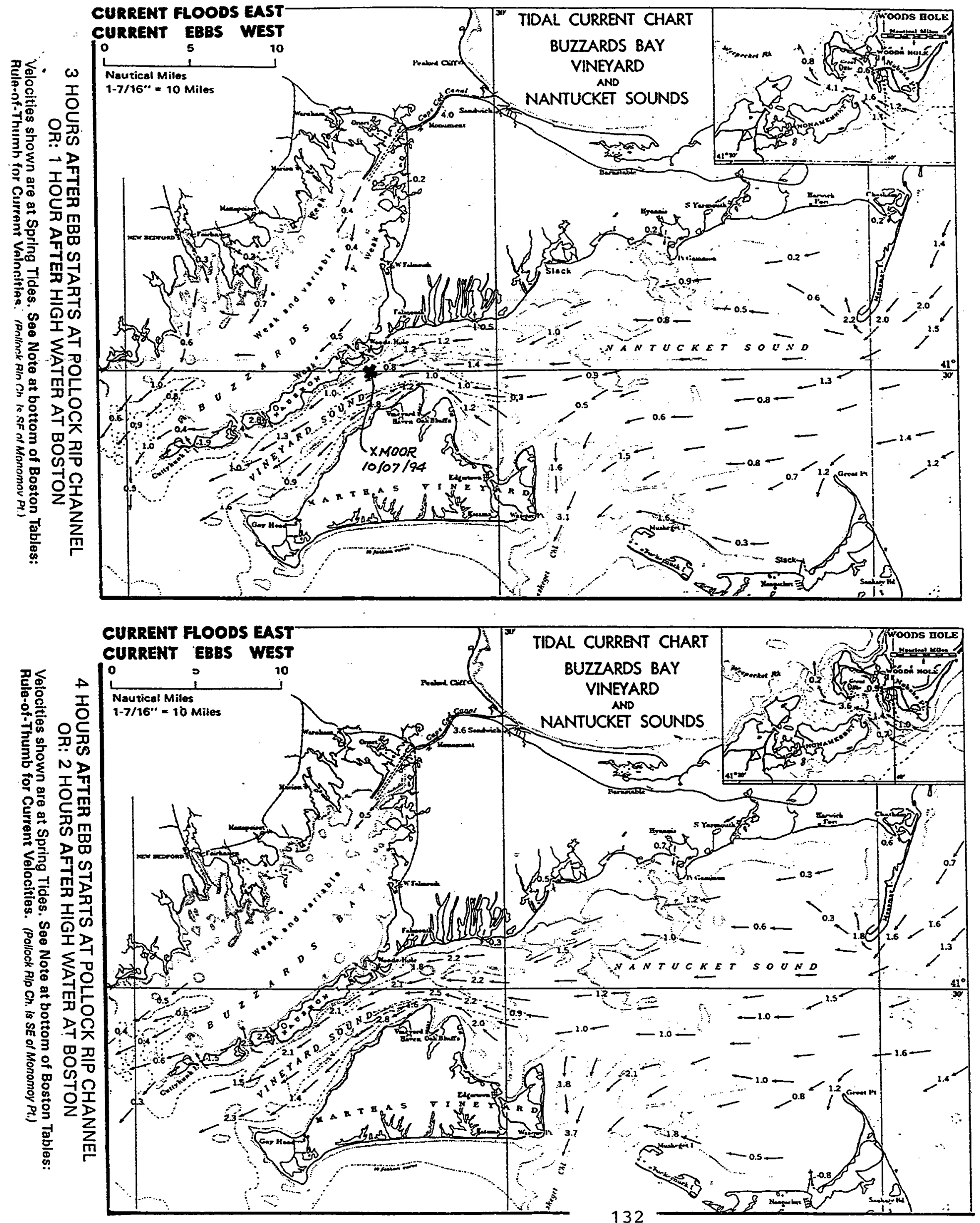


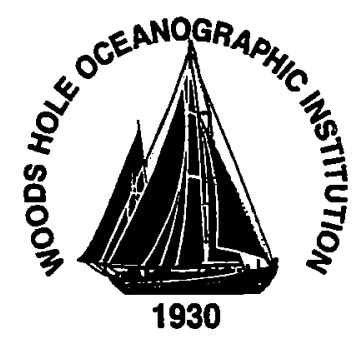

ADVANCED ENGINEERING LABORATORY

MEMO

DATE: $\quad 11 / 04 / 96$

TO: $\quad$ File

FROM: $\quad$ Don Peters, $\times 3377$

Smith 310, MS 17

FILE: $\quad$ xm110496.doc

The XMOOR system \#2 which was self-deployed in Vineyard sound on 10/07/95 was deployed for several extended periods. This memo summarizes the activity.

\title{
Great Harbor
}

The first round involved deployment in Great Harbor, Woods Hole. This tested the system in the absence of currents and waves, i.e. wind only, and within easy sight of the town dock. The sight chosen was a $50 \mathrm{ft}$. deep hole approximately 0.15 naut. mi. west of the town dock, relatively clear of moorings.

The system was put in Great Harbor on November 4, 1994. The inflatable was filled to $3 \mathrm{psi}$ guage at room temperature, with air. $\mathrm{CO}_{2}$ was not used as problems with diffusion had not been solved yet. A lobster float on 3/8" yellow polypropylene was shackled onto the anchor chain about $3 \mathrm{~m}$ up from the anchor, as a backup recovery float. The $30 \mathrm{~m}$ lockup point was engaged with the actuator wing bolted down, as there was no un-latch preventer in the initial prototypes.

The mooring line conductor was fitted with a $100 \mathrm{kOhm}$ resistor at the bottom and was electrically terminated to the stainless steel lower line canister ring. At the top the line was plugged into the bulkhead connector in the lower endcap of the pressure housing. Two leads were brought out of the top of the pressure housing and antenna stem: one connected to the mooring line conductor and one to the buoy seawater return. The intent was that by measuring resistance between the seawater returns at the top and bottom of the system, conductor integrity could be checked periodically without pulling the system out of the water.

Between November 4 and 10, the mooring was seen from shore to swing with the wind (anchor float to windward of the buoy) and remain tautly inflated. Several cold fronts, one with gusts to $45 \mathrm{kts}$,

\author{
WOODS HOLE OCEANOGRAPHIC INSTITUTION \\ SMITH LABORATORY \\ 86 WATER STREET \\ WOODS HOLE, MA 02543
}

PHONE (508)-457-2000 FAX (508)-457-2195 
passed through during this period, and though there were only very small waves the buoy was observed to "kite" almost clear of the water during some puffs.

On November 10 the buoy was checked for electrical continuity, and shorting was indicated. The system was recovered and brought ashore. Upon examination the pressure housing was found to have leaked, causing test lead shorting inside the buoy. The leak was due to a misalignment of the conductivity head caused by fastener interference. The mooring line was undamaged, and the system was re-deployed.

From November 10 until 21 the mooring behaved as expected. On the 21st the anchor float was observed to leeward of the buoy, and after that date the relative position of the float and the buoy remain unchanged. On November 30 the system was recovered. The mooring line between the buoy and line canister was found to have snagged on the bottom in two places. The polyester sleeving was chafed through in two locations but the strength member and conductor were intact.

\title{
Buzzards Bay
}

System \#2 was re-fitted with the new $0.165 "$ O.D. mooring line from line canister to buoy. A $15 \mathrm{~m}$ lockup length was used, since water depths less than $45 \mathrm{ft}$. were expected, and a chinese finger upper termination was made to replace the potted chain/swivel/boot combination. The lockup point and chain of the new lockup type was shackled to a u-bolt fitted through the line canister wall, as the new lockup slides had not been delivered yet. No thermistor string was married to the line and no sleeving was installed except at the upper termination over the chinese finger. The remainder of the original linepack from the Vineyard Sound deployment was left in the canister for weight simulation purposes, and although in a final system the midwater node would not have pulled out at $15 \mathrm{~m}$, for test purposes a dummy node was installed above the $15 \mathrm{~m}$ lockup. The same anchor float was used, and a new anchor (made to better tolerances than the prototype) was used. The instrument housing was fitted with an Argos transmitter and a circuit to detect mooring line conductor integrity.

This system was deployed on January 13,1995 , in Buzzards Bay at approximately $41^{\circ}-32.1^{\prime} \mathrm{N}$, $70^{\circ}-40.6 \mathrm{~W}$, or about $1 / 3$ naut. mi. NNW of the MBL Beach. This site is sheltered from the SW to E, but is relatively exposed (4-6 mi fetch) to the NE, and exposed (full Buzzards Bay fetch) from $\mathrm{N}$ to W. Water depth is approximately $40 \mathrm{ft}$. and tides are not likely to exceed $1 / 2 \mathrm{kt}$. The bottom is shown on the chart as mud. This site has the advantage that it is visible from the MBL beach.

Upon deployment it was noted that the anchor float was perhaps on too long a line, and by next morning the float had fouled the buoy. Bad weather prevented going to fix this for several days. On January 19 the anchor float line was cleared from the buoy and shortened up to about $6 \mathrm{ft}$. more than the water depth. ARGOS not receiving sufficient hits for position more than about once a day. Antenna problems suspected.

On January 31, 1995 the buoy was not on station, although the marker float was present. ARGOS position had not been recently updated. The lower part of the system was hauled using the marker float. It was noted that the line canister had become fully embedded in the very sticky bottom at this site. The vectran line was found to have broken just below the puck. The buoy was spotted where it had gone ashore a short distance to the northeast and lodged in a riprap wall. The inflatable was intact and holding air, though the buoy had evidence of a bad pounding on the rocks. The line had pulled out of the puck and the puck was gone.

\author{
WOODS HOLE OCEANOGRAPHIC INSTITUTION \\ SMITH LABORATORY \\ 86 WATER STREET \\ WOODS HOLE, MA 02543
}

PHONE (508)-457-2000 FAX (508)-457-2195 
This failure led to the following conclusions: First, that the combined bending and tension occurring at the puck needed to be eliminated. Second, the unwanted embedment of the line canister resulted in a system without the scope and shock-absorption that the anchor chain was desigined to provide. Third, that the inflatable buoy was surprisingly tough in abrasion resistance.

\title{
Design Changes Resulting from Failure
}

The first problem led to a design whereby mechanical lanyards above and below the puck take the tension from the mooring line and pass it directly through the puck housing, resulting in a site of bending without tension at the puck. The lanyards are the same as those used for the lockup points and the buoy termination.

A number of ideas for preventing line canister embedment were discussed. One involved adding enough flotation to the canister to keep it off the bottom. It was found that to make the canister neutrally buoyant using foam of $6 \mathrm{pcf}$, about 8 inches of interior length would have to be filled (with the OD constraint on the design, no flotation could be added to the outside of the package.) A canister was fitted with foam inside and tested. It was found to exhibit a great deal of undamped motion, which would clearly result in line tangling. The lack of available interior room for foam-filling and the extreme activity of the neutrally ballasted canister led us to abandon floating the line canister as a solution to the problem for this design. A second solution discussed, but never implemented, was to provide a flexible fabric collar around the upper canister opening, which would allow line and pucks to pull out, while keeping mud from coming in.

It should be noted that both problems resulted when the system was deployed at a site with little tidal action, causing the mooring to stay very slack. It is interesting that this may be a design condition more difficult to engineer for than our target conditions of maximum depth and current, where the mooring stays taught for a large part of the time.

\section{System \#3 Deployments}

During the winter and spring of 1995, a redesign of XMOOR was performed, and 8 units of the modified design produced. Modifications were largely made to simplify production and reduce the mechanical parts count.

In June of 1995, two systems were self-deployed at Woods Hole for testing of telemetry systems. Subsequent to that testing, one unit was retained for mechanical testing in waters around Woods Hole. This unit was fitted with a battery pack and PTT only, for position during testing. A large portion of the retrieval/redeployments performed during these tests resulted from continuing problems with low ARGOS hit rates. A change of PTT units and adaptation of a whip antenna eventually tesulted in reliable position updates. The large number of retrievals had the advantage of allowing for a good visual check on any wear point development over the course of the testing. A summary of the testing follows.

$6 / 29-6 / 30$

$6 / 30-7 / 20$

$7 / 20-7 / 21$

$7 / 21-7 / 26$

\section{Great Harbor}

Buzzards Bay, off MBL Beach

Refit with new PTT, Overnight on dock to check position hits

Redeploy system at position $41^{\circ}-33.3^{\prime} \mathrm{N} 70^{\circ}-42.5^{\prime} \mathrm{W}$, referred to as "XMOOR1" position, approx. 2 NM Northwest of Woods Hole Passage, in Buzzards Bay. Water depth $17 \mathrm{~m}$.

\author{
WOODS HOLE OCEANOGRAPHIC INSTITUTION \\ SMITH LABORATORY \\ 86 WATER STREET \\ WOODS HOLE, MA 02543
}

PHONE (508)-457-2000 FAX (508)-457-2195 
$7 / 26-8 / 3$

$8 / 3-8 / 17$

$8 / 17$

$8 / 17-9 / 11$

$9 / 11$

$9 / 15$

$9 / 15-10 / 14$

$10 / 14$

$10 / 15$

$10 / 17$

PTT not working, system retrieved, fitted with new unit

On station. Numerous visual checks, ARGOS positions unreliable

Whip antenna fitted for PTT

On station

Inflatable appears soft. Has been outside in water or on land 137 days. Replaced with new inflatable. No change in inflation noted after replacement. Possible temperature/pressure effect?

System deployed at "XMOOR2" in Vineyard Sound, position $41^{\circ}-29.6^{\prime} \mathrm{N}, 70^{\circ}-41.8^{\prime} \mathrm{W}$, about 1/2 NM south of Lackey's bay. Water depth $24 \mathrm{~m}$. Tides running NE/SW approx 2.5 knots max. Separate marker float located $15 \mathrm{~m}$ downstream of buoy with tide flowing SW.

On station. Various checks reveal no change in position or mechanical wear points Southwest gale, winds $40-50 \mathrm{kt}$

ARGOS Position bad, buoy off station to northwest, weather still rough Buoy recovered using ARGOS position and visual, Bishop Shoal, south of Hyannis

Failure Discussion

Failure of the mooring was once again at the puck. The puck-bypass lanyard below the puck had chafed through at the thimble, and once it parted the mooring line parted at the location it passed into the puck. The puck was recovered with the buoy, and the mooring line had noticeable weakening where it passed into the puck from above.

The total time in Buzzards Bay was 62 days, and time in Vineyard Sound was 32 days before failure, for a total of 94 days. The puck-bypass lanyard that failed was, as were all lockup and termination lanyards on that particular test mooring line, made of a hollow-braid Vectran strength member from the previous, larger version of XMOOR. The use of this Vectran hollow-braid was a choice of convenience only, for the purpose of getting a line assembled for the June electrical tests. Subsequently, a hollow-braid Spectra line was used for the lanyards. This is significant, since Vectran is poor in abrasion resistance and is not usually used without an abrasion-resistant cover. This failure mode would not be expected from a line using the Spectra lanyards.

The apparent weakening of the line at the puck would eventually have led to electrical failure of the mooring conductor and thus the system. There is a great deal of motion at the points where the line passes into and out of the puck. A softening of the puck pass-through edges to allow for a more gradual entrance and exit would be expected to reduce line damage at these locations.

WOODS HOLE OCEANOGRAPHIC INSTTTUTION

SMITH LABORATORY

86 WATER STREET

WOODS HOLE, MA 02543

PHONE (508)-457-2000 FAX (508)-457-2195 
LAMINATING COATING TECHNOLOGIES, INC.

LAMCOTEC, INC.

152 BETHANY ROAD

MONSON MA 01057 - 0279

TEL: (413) $267-4808$

FAX: (413) $267-5265$
LABORATORY REPORT

NUMBER:

APPENDIX 6.3 .5
LCT SPECIFICATION

NUMBEF: $\quad X X X X$

PRODUCT DESCRIPTION:

HEAT SEALABLE URETHANE

SEA RESCUE ORANGE, 210 DENIER NYLON OXFORD

LCT SPECIFICATION NUMBER

LCT FACTORY ORDER NUMBER

LCT INVOICE NUMBER

LCT MANUFACTURING DATE

TRIMMED WIDTH, CENTIMETERS

TRIMMED WIDTH, INCHES

NUMBER OF ROLLS

NUMBER OF NET LINEAL METERS

NUMBER OF NET LINEAL YARDS

BILL OF LADING NUMBER

SHIPPED VIA 
TEST REFERENCES: $\quad$ MIL-C-83489 (18 MAY 1977)

FEDERAL STANDARD 191A (JULY 20, 1978)

COMPLIANCE CERTIFICATE: I HEREBY CERTIFY THAT THE MATERIALS TENDERED BY THIS REPORT HAVE BEEN MANUFACTURED AND TESTED IN COMPLIANCE WITH THE AFOREMENTIONED SPECIFICATIONS.

\begin{tabular}{|c|c|c|c|}
\hline TEST & $\begin{array}{l}\text { TEST } \\
\text { METHOD }\end{array}$ & RESUET & REQUIREMENT \\
\hline $\begin{array}{l}\text { WEIGHT } \\
\text { (1) }\end{array}$ & 5041 & $\begin{array}{l}261.65 \text { GRAMS / SQUARE METER } \\
7.71 \text { OUNCES / SQUARE YARD }\end{array}$ & $\begin{array}{l}\text { MIN. } \\
\text { MAX. } \\
\text { MAX. }\end{array}$ \\
\hline $\begin{array}{l}\text { BREAKING } \\
\text { STRENGTH } \\
\text { (2) }\end{array}$ & 5102 & $\begin{array}{l}1606.73 \text { NEWTONS / } 50 \text { MILLIMETERS } \\
1098.88 \\
367.00 \text { POUNDS / } 2 \text { INCH } \\
251.00\end{array}$ & $\begin{array}{l}\text { MIN.warp } \\
\text { MIN.fill } \\
\text { MIN.warp } \\
\text { MIN.weft }\end{array}$ \\
\hline $\begin{array}{l}\text { BREAKING } \\
\text { STRENGTH } \\
\text { GRAB } \\
\text { (3) }\end{array}$ & 5100 & $\begin{array}{l}1203.95 \text { NEWTONS / } 25 \text { MILLIMETERS } \\
919.38 \\
275.00 \text { POUNDS / } 1 \text { INCH } \\
210.00\end{array}$ & $\begin{array}{l}\text { MIN.warp } \\
\text { MIN.fill } \\
\text { MIN.warp } \\
\text { MIN.weit }\end{array}$ \\
\hline $\begin{array}{l}\text { TONGUE } \\
\text { TEAR } \\
\text { (4) }\end{array}$ & $\begin{array}{l}5134 \\
5100\end{array}$ & $\begin{array}{l}15.12 \text { NEWTONS } \\
8.90 \\
3.40 \text { POUNDS } \\
2.00\end{array}$ & $\begin{array}{l}\text { MIN.warp } \\
\text { MIN.fill } \\
\text { MIN.warp } \\
\text { MIN.weft }\end{array}$ \\
\hline $\begin{array}{l}\text { TRAPEZOID } \\
\text { TEAR }\end{array}$ & $\begin{array}{l}5136 \\
5100\end{array}$ & $\begin{array}{l}30.25 \text { NEWTONS } \\
20.46 \\
6.80 \text { POUNDS } \\
4.60\end{array}$ & $\begin{array}{l}\text { MIN.warp } \\
\text { MIN.fill } \\
\text { MIN.warp } \\
\text { MIN.weft }\end{array}$ \\
\hline $\begin{array}{l}\text { BREAKAWAY } \\
\text { ADHESION } \\
(6)\end{array}$ & $\begin{array}{l}\text { PARA. } \\
4.4 .1 \\
5102\end{array}$ & 356.81 NEWTONS / 25 MILLIMETERS & $\begin{array}{l}\text { MIN.warp } \\
\text { MIN.warp }\end{array}$ \\
\hline
\end{tabular}


TEST

TEST

RESULT

REQUIREMENT

METHOD

\begin{tabular}{ll}
\hline STRIP & 5970 \\
ADHESION & 5102
\end{tabular}

(7) 5102

166.36 NEWTONS / 25 MILLIMETERS

38.00 POUNDS / 1 INCH
MiN.warp

MIN.warp

\begin{tabular}{|c|c|c|c|}
\hline $\begin{array}{l}\text { PERMEABILITY } \\
\text { TO HELIUM GAS } \\
\text { (8) }\end{array}$ & $\begin{array}{l}\text { TSO C13f } \\
\text { APP. } 1(6) \\
\text { ASTM D1434-82 }\end{array}$ & $\begin{array}{l}\text { TEST } \\
\text { NOT } \\
\text { RUN }\end{array}$ & 2.00 LITERS-/ SQ.M. / 24 HRS. MAX \\
\hline $\begin{array}{l}\text { AIR } \\
\text { (9) }\end{array}$ & $\begin{array}{l}\overline{\bar{P} A \bar{R} \bar{A} .} \\
4.4 .2\end{array}$ & $\begin{array}{l}\text { PASS } \\
\text { PASS }\end{array}$ & $\begin{array}{l}\text { NO LEAKS / } 10 \text { PSIG / } 5 \text { MINUTES } \\
\text { NO LEAKS / } 69 \mathrm{kPa} / 5 \text { MINUTES }\end{array}$ \\
\hline $\begin{array}{l}\text { LOW } \\
\text { TEMPERATUAE } \\
(10)\end{array}$ & $\begin{array}{l}\text { PARA. } \\
4.4 .3\end{array}$ & PASS & $\begin{array}{l}\text { NO CRACKING, FLAKING OR } \\
\text { SEPARATION }\end{array}$ \\
\hline
\end{tabular}

SIGNED:

AICHARD J. ANDERSON, JR.

VICE PRESIDENT - OPERATIONS

SIGNED:

RICHĀẼ J. MALLo

QUALITY CONTROL DEPARTMENT

SIGNED:

WILLIAM $\bar{P}$. REEED

LABORATORY 
. 


\section{DOCUMENT LIBRARY}

Distribution List for Technical Report Exchange - February 1996

University of California, San Diego

SIO Library 0175C

9500 Gilman Drive

La Jolla, CA 92093-0175

Hancock Library of Biology \& Oceanography

Alan Hancock Laboratory

University of Southern California

University Park

Los Angeles, CA 90089-0371

Gifts \& Exchanges

Library

Bedford Institute of Oceanography

P.O. Box 1006

Dartmouth, NS, B2Y 4A2, CANADA

Commander

International Ice Patrol

1082 Shennecossett Road

Groton, CT 06340-6095

NOAA/EDIS Miami Library Center

4301 Rickenbacker Causeway

Miami, FL 33149

Research Library

U.S. Army Corps of Engineers

Waterways Experiment Station

3909 Halls Ferry Road

Vicksburg, MS 39180-6199

Institute of Geophysics

University of Hawaii

Library Room 252

2525 Correa Road

Honolulu, HI 96822

Marine Resources Information Center

Building E38-320

MIT

Cambridge, MA 02139

Library

Lamont-Doherty Geological Observatory

Columbia University

Palisades, NY z10964

Library

Serials Department

Oregon State University

Corvallis, OR 97331

Pell Marine Science Library

University of Rhode Island

Narragansett Bay Campus

Narragansett, RI 02882
Working Collection

Texas A\&M University

Dept. of Oceanography

College Station, TX 77843

Fisheries-Oceanography Library

151 Oceanography Teaching Bldg.

University of Washington

Seattle, WA 98195

Library

R.S.M.A.S.

University of Miami

4600 Rickenbacker Causeway

Miami, FL 33149

Maury Oceanographic Library

Naval Oceanographic Office

Building 1003 South

1002 Balch Blvd.

Stennis Space Center, MS, 39522-5001

Library

Institute of Ocean Sciences

P.O. Box 6000

Sidney, B.C. V8L 4B2

CANADA

National Oceanographic Library

Southampton Oceanography Centre

European Way

Southampton SO14 3ZH

UK

The Librarian

CSIRO Marine Laboratories

G.P.O. Box 1538

Hobart, Tasmania

AUSTRALIA 7001

Library

Proudman Oceanographic Laboratory

Bidston Observatory

Birkenhead

Merseyside L43 7 RA

UNITED KINGDOM

IFREMER

Centre de Brest

Service Documentation - Publications

BP 7029280 PLOUZANE

FRANCE 



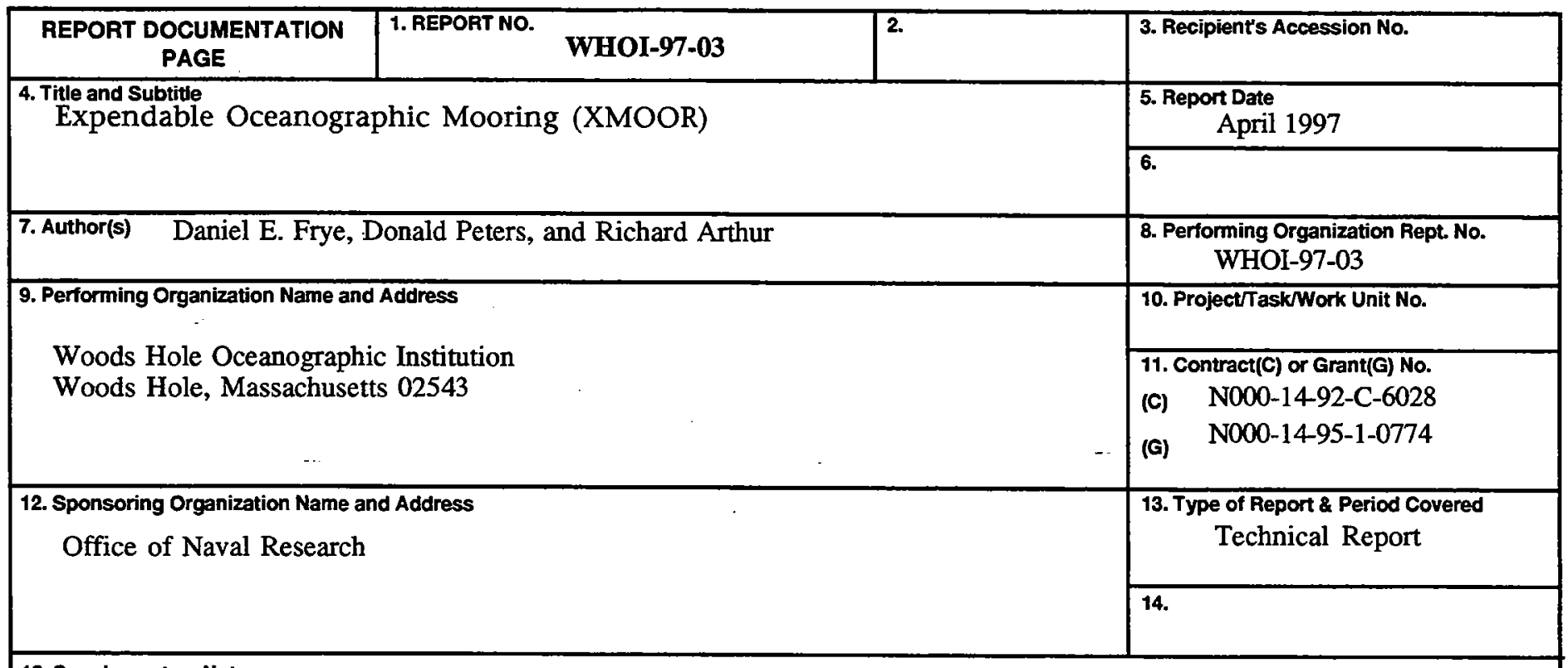

15. Supplementary Notes

This report should be cited as: Woods Hole Oceanog. Inst. Tech. Rept., WHOI-97-03.

\section{Abstract (Limit: 200 words)}

An expendable, self-deploying mooring (XMOOR) for shallow water applications has been developed to address Navy requirements for environmental monitoring. The project has been conducted jointly between the Woods Hole Oceanographic Institution and the Naval Research Laboratory at Stennis, MS. WHOI has taken the lead on the mechanical design of the system while NRL has developed the electronics.

Eight prototype XMOOR systems have been built. They are designed for water depths between 10 and $100 \mathrm{~m}$, for deployments of up to 3-months duration, and for automatic deployment. Their sensor suite includes barometric pressure, air temperature, water temperature at up to 25 levels, and conductivity and pressure at up to 3 levels. Data telemetry is accomplished via the Argos DCS and by line-of-sight VHF configuration of the data collection program.

This report describes the XMOOR mechanical system. The data collection and telemetry systems are described separately in (1) and (2).

\section{Document Analysis a. Descriptors}

expendable mooring

self-deploying mooring

inductive telemetry

b. Identifiers/Open-Ended Terms

c. COSATI Field/Group

18. Availability Statement

Approved for public release; distribution unlimited.

\begin{tabular}{|l|l|}
$\begin{array}{c}\text { 19. Security Class (This Report) } \\
\text { UNCLASSIFIED }\end{array}$ & $\begin{array}{l}\text { 21. No. of Pages } \\
143\end{array}$ \\
\hline 20. Security Class (This Page) & 22. Price \\
\hline OPTIONAL FORM 272 (4-77) \\
$\begin{array}{l}\text { OPormerly NTIS-35) } \\
\text { Department of Commerce }\end{array}$ \\
\hline
\end{tabular}

